UNIVERSIDADE DE SÃO PAULO

FACULDADE DE FILOSOFIA, LETRAS E CIÊNCIAS HUMANAS

DEPARTAMENTO DE FILOSOFIA

PROGRAMA DE PÓS-GRADUAÇÃO EM FILOSOFIA

\title{
ESTÉTICA E POLÍTICA EM MÁRIO PEDROSA (1930-1950)
}

Marcelo Mari

Tese apresentada ao Programa de Pós-Graduação em Filosofia da Faculdade de Filosofia, Letras e Ciências Humanas da Universidade de São Paulo, para obtenção do título de Doutor em Filosofia.

Orientador: Prof. Dr. Celso Fernando Favaretto

São Paulo

2006 
UNIVERSIDADE DE SÃO PAULO

FACULDADE DE FILOSOFIA, LETRAS E CIÊNCIAS HUMANAS

DEPARTAMENTO DE FILOSOFIA

PROGRAMA DE PÓS-GRADUAÇÃO EM FILOSOFIA

\section{ESTÉTICA E POLÍTICA EM MÁRIO PEDROSA (1930-1950)}

Marcelo Mari

São Paulo

2006 
Dedicatória:

Para Ivani, minha mãe;

Alzira, minha avó;

Aníbal, meu tio.

Para minha companheira, Camila. 
Agradecimentos:

A Cristina Daniels.

A Iná Camargo Costa e José Castilho Marques Neto, sem os quais esta pesquisa não se realizaria.

A Celso Fernando Favaretto pela confiança em meu trabalho.

Aos amigos que participaram de minha vivência e luta na USP.

Agradeço também a CAPES pelo apoio financeiro desta pesquisa. 


\section{Resumo:}

Esta pesquisa visa apresentar a articulação entre arte e política na trajetória de Mário Pedrosa durante as décadas de 1930 a 1950. Se, na conferência de 1933, sobre a gravurista alemã Käthe Kollwitz, Pedrosa esboçou os princípios de uma estética marxista, que tentou vincular a natureza, a origem e o desenvolvimento da arte com o estágio técnico alcançado pela sociedade e com a luta de classes, de 1942 em diante, a ênfase se deu na especificidade e nas leis próprias do campo artístico. Embora Pedrosa tivesse sempre em mente o processo final de síntese entre arte e revolução social, processou-se uma mudança em seu posicionamento. Este derivou não do afastamento premeditado da política para a dedicação exclusiva à atividade de crítica de arte, mas de um ajuste necessário de Pedrosa para articular de outro modo arte e política, a fim de que os augúrios do campo artístico se concretizassem.

Palavras-chave: Mário Pedrosa, realismo, abstracionismo, Portinari, tendência construtiva

\section{Abstract:}

The object of this research is to show the connection between art and politics in Mário Pedrosa's pathway during the decades of 1930 to 1950. If in his lecture on the German engraver Käthe Kollwitz in 1933 Pedrosa had outlined the principles of a Marxist aesthetics, which tried to link up the nature, origin and development of art with the technical stage reached by society and the class struggle, from 1942 onwards, he put emphasis on the specificity and the proper laws of the artistic field. Although Pedrosa had always in mind the final process of syntesis between art and social revolution, there has been a shift in his position. This derived not from his deliberate withdrawal from politics in order to devote himself exclusively to his role as an art critic, but from a necessary adjustment to connect art with politics in another way, so that the prospects for the artistic field might be achieved.

Key-words: Mário Pedrosa, realism, abstracionism, Portinari, constructive tendency 
Sumário:

Introdução

p. 08

Capítulo 1. Mário Pedrosa e a arte como arma revolucionária

Os descaminhos da política na URSS e a ascensão do Nazismo

p. 19

A luta contra o Integralismo e contra a ideologia da colaboração de classes

p. 25

O despertar da consciência política no ambiente artístico brasileiro

p. 38

Um divisor de águas na crítica brasileira: a conferência sobre Käthe Kollwitz

p. 49

Capítulo 2. $\underline{\mathrm{O} \text { apelo trotskista e a defesa da arte independente }}$

A virada de cento e oitenta graus na política externa da URSS

p. 72

A esquerda e a política governamental para as artes nos Estados Unidos

p. 78

Apelo trotskista: o Manifesto por uma arte revolucionária independente

p. 88

Política e cultura: a ação dos Estados Unidos na América Latina

p. 108

A missão cultural norte-americana e Cândido Portinari

p. 119

Os murais de Portinari em Washington

p. 125

Capítulo 3. A tradição moderna no Brasil: Portinari e a crítica de Pedrosa

Fim do Estado Novo - reconfiguração política nacional e internacional

p. 144

Vanguarda Socialista: formação de consciência, democracia e liberdade

p. 152

Vanguarda Socialista: o caso Portinari

p. 166

Solução ou impasse? - A contribuição de Portinari para a arte moderna brasileira p. 179

O Tiradentes de Portinari e a mítica brasileira do herói nacional

p. 192 
Capítulo 4. De Cândido Portinari à tendência construtiva: o legado de Mário Pedrosa

$\begin{array}{ll}\text { De Cândido Portinari à tendência construtiva } & \text { p. } 208\end{array}$

$\begin{array}{ll}\text { A reivindicação de mais consciência e a função da arte moderna } & \text { p. } 230\end{array}$

$\begin{array}{ll}\text { Crise da representação: percepção renovada e crítica da arte assimilada } & \text { p. } 245\end{array}$

$\begin{array}{ll}\text { Conclusão } & \text { p. } 268\end{array}$

$\begin{array}{ll}\text { Bibliografia } & \text { p. } 272\end{array}$ 
Introdução 


\section{$\underline{\text { Introdução }}$}

Ativista político e grande conhecedor das artes, Mário Pedrosa contribuiu de modo decisivo na formação e no desenvolvimento do meio político e artístico brasileiro do século XX. Pode-se dizer que sua trajetória acompanha de perto as principais transformações do século, pois Pedrosa tratou sempre de analisar o plano local e o plano internacional e de propor intervenções capazes de promover a transformação concreta da sociedade. Essa empreitada assumida pelo intelectual brasileiro pode ser averiguada por suas atividades proeminentes na política e nas artes, bem como por sua copiosa produção ensaísta. Se, ademais, o brilho intelectual de Pedrosa residiu no domínio consistente de uma ampla gama de conhecimentos para explicação dos fenômenos próprios de nossa época, a tentativa de interpretar sua ação consciente apresentou-se como uma tarefa árdua, suscetível de soçobrar nas idas e vindas de uma análise - com poucos pares entre os intelectuais brasileiros - robusta e que esteve continuamente atenta à complexidade dos acontecimentos.

Em 1933, Pedrosa pronunciou uma conferência sobre a gravurista alemã Käthe Kollwitz e defendeu uma arte tendenciosa, que tomasse partido em favor da luta revolucionária e internacionalista do proletariado. Quase nove anos depois, no início da década de 1940, processou-se uma mudança na predileção do crítico que passou a apoiar uma arte sem mensagem social ou política explícita. Tratava-se do abandono da influência dos elementos extrínsecos na arte e predominância de sua especificidade e leis internas. As consequiências dessa mudança iam muito além de um suposto interesse de Pedrosa em promover as manifestações mais renovadas da arte moderna e incidiam sobre o próprio entendimento dele sobre a arte e sobre a política. Na verdade, a explicação da mudança de interesse da arte proletária para o abstracionismo é um dos assuntos mais controvertidos na análise da obra de Pedrosa. Essa mudança, entretanto, pode fornecer subsídios tanto para se compreender de que modo Pedrosa entendia a articulação entre a arte e o momento político e social vivido como para o esclarecimento do significado atribuído pelo crítico à natureza da atividade artística.

O problema da interpretação da obra de Pedrosa reside na opinião mais ou menos consolidada, até nossos dias, sobre as consequiências da mudança de predileção do crítico que apoiou a arte proletária na década de 1930 e a arte autônoma durante a 
década de 1940. A mudança prediletiva parecia implicar a passagem de uma interpretação marxista para a atuação de Pedrosa somente como crítico de arte mais afeito às leis próprias da atividade artística. Se, na conferência sobre Käthe Kollwitz havia a intenção de articular arte e política, logo depois do contato com a obra de Alexander Calder, Pedrosa abandonava de vez a articulação com a política e se interessava exclusivamente pela arte. Essa foi a interpretação que prevaleceu entre os autores da velha-guarda: Luís Washington Vita ${ }^{1}$ e José Antônio Tobias ${ }^{2}$. Ambos enfatizaram a mudança de posicionamento do crítico. Havia pois que se identificar dois momentos da crítica de Pedrosa, um preocupado em relacionar a arte com as premências do tempo social e político vivido e outro em que a arte ganharia importância maior e se consolidaria como campo específico da atividade humana.

Nos anos de 1970, uma nova geração de estudiosos contestou a separação anteriormente apregoada entre arte e política na obra de Pedrosa. Tratava-se de fazer jus à trajetória do intelectual militante e retomar a importância de sua contribuição crítica para as artes no Brasil. Entre esses estudiosos se destacaram: Aracy A. Amaral e Otília Beatriz Fiori Arantes. Responsável pela primeira publicação dos textos de crítica de Pedrosa, Aracy Amaral salienta que ele não foi um novidadeiro, mas um intelectual atento às questões de seu tempo, sempre preocupado em articular o momento político e social com a arte e vice-versa: "A grande contribuição de Mário Pedrosa à arte brasileira não reside, a nosso ver, em ter sido um estimulador das vanguardas, porém em sua configuração como crítico, alerta para as inquietações do intelectual e do artista, em diálogo com seu tempo, permanentemente questionando a articulação entre arte e

\footnotetext{
${ }^{1}$ José Antônio Tobias diz: "Dissemos ser Astrojildo Pereira a primeira 'pessoa", e não a primeira obra, de filosofia marxista, escrita no Brasil, marco este plantado, em 1949, pela Arte, Necessidade Vital, de Mário Pedrosa, que posteriormente, em obras, como Dimensão da Arte, haveria de abandonar a filosofia marxista.” TOBIAS, J. A. História da idéias estéticas no Brasil. São Paulo: Editorial Grijalbo, 1967, p. 155 .

${ }^{2}$ Mais completo que o comentário de José Antônio Tobias, o de Luís Washington Vita enuncia o problema da trajetória de Pedrosa nos anos de 1930 e 1940: "Adotando o materialismo histórico como método de compreensão da realidade social, chega Mário Pedrosa aos tempos modernos, 'com a sociedade dividida em duas classes irredutivelmente antagônicas', diante da 'implacável batalh das duas classes inimigas', sendo uma delas, o proletariado, 'a classe que surgiu por último na história'. Como 'pintora da sensiblidade cósmica do proletariado' apresenta Kollwitz. Toda esta armação teórica parece ruir no último de seus livros, pois a arte, agora, é um 'vastíssimo e insondável complexo fenômeno' e que, em lugar de imitar, 'apenas sugere', porquanto consiste a obra de arte em seu 'poder de transformação expressiva'. Sendo representação visionária do mundo, essa transfiguração, 'sob uma dimensão de realidade mais profunda, é o milagre da arte". VITA, L. W. Tendências do pensamento estético contemporâneo no Brasil. Rio de Janeiro: Civilização Brasileira, 1967, p. 94.
} 
política. Essa preocupação emerge em seus textos da década de 30, nos anos 60, e no fato de que nos últimos anos de sua vida tornaria a interessar-se pela política"3.

O mérito de Aracy Amaral foi o de avaliar a trajetória de Pedrosa, como crítico de arte, no desdobramento dos acontecimentos do meio artístico brasileiro. Entretanto, a autora não esclarece de modo satisfatório como Pedrosa articula arte e política e parece considerar o interesse do crítico pelo abstracionismo e pela arte de tendência construtiva, nos anos de 1940 e 1950, menos como uma resposta política à conjuntura histórica do que como uma ênfase na especificidade da arte - por essa já processar uma revolução na sensibilidade do homem contemporâneo ${ }^{4}$. O problema da divisão da obra de Pedrosa em dois momentos permanece e pode ser até mesmo enfatizado pela própria declaração do crítico no final dos anos 60. Pedrosa diz de si próprio: “Adotando então como se era ingênuo logo após a Segunda Grande Guerra - ponto de vista de mero crítico de arte, clamávamos porque os nossos artistas visuais ainda não se haviam acomodado ao movimento cinético e à visão multiangular do cinema e do avião." $\mathrm{De}$ fato, ele assumiu posição de crítico de arte, nos anos 40 e 50, e articulou de outra maneira arte e política. Enfatizando a especificidade do campo artístico, Pedrosa recuperava o sentido social da arte e tentava construir barricadas contra a instrumentalização política da arte no Brasil e no mundo.

No que se refere ao esclarecimento do significado atribuído à natureza da atividade artística, Otília Arantes foi quem melhor analisou a obra de Pedrosa ${ }^{6}$. A autora se ateve à definição de que para o crítico a própria natureza e a finalidade última da arte coincidiam com os anseios depositados m revolução social e, por conseguinte, com a realização plena do homem. Portanto, arte e transformação profunda do mundo caminhavam juntas: "Como ficou dito, esses ensaios sobre Portinari nos permitem, até certo ponto, retraçar o itinerário crítico de Mário Pedrosa. Preocupado inicialmente com as imposições da matéria, sobretudo da matéria social, passando pelo elogio do muralismo, valorização crescente da especificidade da arte - é bem verdade que em sua

\footnotetext{
3 AMARAL, A. A. Arte para quê? - a preocupação social na arte brasileira (1930-1970). São Paulo: Studio Nobel, 2003, p. 06.

${ }^{4}$ Idem, ibidem, pp. 250-252.

5 PEDROSA, M. “A passagem do verbal ao visual” In Homem, mundo, arte em crise. (org. Aracy A. Amaral). São Paulo: Perspectiva, 1986, p. 148.

${ }^{6}$ A motivação para a feitura da presente pesquisa surgiu durante o "Seminário Mário Pedrosa e o Brasil: 100 anos de arte e política”, promovido pela Fundação Perseu Abramo, nos dias 21, 22 e 23 de agosto do ano 2000. Entre as sessões do seminário, ocorreu uma, no dia 2 , terça-feira, às 19 horas, intitulada "Crítica, Arte e Educação". Nela, Otília Arantes enfatizou que em geral havia uma tendência dos estudiosos de Mário Pedrosa em separar sua obra política e sua obra estética e que era necessário compreender o vínculo existente entre elas.
} 
conferência inaugural não chegava a ver uma antinomia nessa repartição da dimensão estética. Se a ênfase muda, o que é sempre perseguido neste esforço de decifração das obras, é a sua vocação sintética e universalizadora. Descoberto esse núcleo, a oposição entre a defesa de uma arte proletária e a tomada de partido em prol da abstração (ou da arte concreta) não é tão radical como se pretende."7

Se Otília Arantes decifrou a compreensão de Pedrosa sobre a natureza e finalidade última da arte, nem por isso é possível concluir que não houvesse oposição, ou ainda que esta não fosse tão fundamental, entre a defesa que o crítico fez primeiro da arte proletária e depois do abstracionismo e da arte de tendência construtiva. Certamente, são dois momentos da crítica de Pedrosa motivados pela mesma compreensão da natureza e finalidade última da arte. A oposição entre esses momentos explicou-se pelo caráter revolucionário ou conservador da manifestação artística, que se revelou através do exame da conjuntura histórica e social em que ela foi produzida ${ }^{8}$. Em outras palavras, a vocação sintética e universalizadora da arte é acompanhada da dimensão histórica propriamente dita e o telos da arte encontra sua função crítica. A defesa da arte proletária e, posteriormente, da arte autônoma funcionou como contraponto crítico e contestador da realidade em dado momento político e social vivido ${ }^{9}$. Assim, a predileção de Pedrosa em favor dessas ou daquelas manifestações artísticas seguiu invariavelmente de perto sua avaliação sobre a conjuntura histórica e de que forma se articulava arte e política.

Esta pesquisa não tentou encontrar analogias entre o pensamento político de Pedrosa e sua produção como crítico de arte, pois ainda que isso fosse possível, a articulação entre arte e política tornar-se-ia muito geral e fugidia. Embora haja referências esparsas ao seu pensamento político, o que se pretendeu foi entender de que modo Pedrosa se situava como crítico de arte frente aos problemas estéticos, políticos e sociais de seu tempo. Nunca é demais salientar que a predileção e o posicionamento do crítico não se referiam apenas ao âmbito da arte, mas tinham conseqüências para além da dimensão artística propriamente dita. Desse modo, partiu-se, invariavelmente, da descrição dos principais impasses políticos e sociais de época, dos problemas próprios do meio artístico e do estado das artes para a elucidação do posicionamento crítico de

\footnotetext{
${ }^{7}$ ARANTES, O. B. F. Mário Pedrosa: itinerário crítico. São Paulo: Cosac Naify, 2004, pp. 49-50.

${ }^{8}$ Cf. ADORNO, T. W. "Engagement" In Notes sur la littérature. Paris: Flammarion, 1984, p. 298 e seguintes.

9 Cf. TROTSKI, L. “A arte e a revolução” In BRETON, A. \& TROTSKI, L. Por uma arte revolucionária independente. São Paulo: Paz e Terra: CEMAP, 1985, p. 99.
} 
Pedrosa. Tendo sempre em vista a vocação sintética e universalizadora da arte, o crítico exerceu sua atividade e tomou posição frente às diversas manifestações artísticas de cada época. A arte, em suas soluções mais felizes, apresentava-se como contestadora da realidade e como promessa da realização plena do homem.

A mudança de predileção do crítico da arte proletária para o abstracionismo foi analisada por meio da comparação entre a concepção de realismo inscrita na conferência sobre Käthe Kollwitz, com seu desdobramento no artigo "Impressões de Portinari" de 1934, e a concepção de arte independente veiculada a partir do ensaio 'Portinari - de Brodósqui aos murais de Washington" de 1942. Por ser um dos pintores mais importantes e aclamados no Brasil do final da década de 1930 e durante a década de 1940, Portinari recebeu atenção especial de Pedrosa. É justamente no esforço do crítico em deslindar as obras, as fases e os novos rumos seguidos por Portinari, que se pode identificar a mudança de ênfase sobre qual seria a manifestação artística mais revolucionária para a época. Em meados de 1940, o pintor envereda para a política e reafirma a via realista na ate. Por sua vez, Pedrosa tomou a decisão de defender o abstracionismo como alternativa contra o naturalismo, academicismo e o realismo em arte. Em 1948, Pedrosa identificou, na "Primeira Missa" de Portinari, a ênfase na pesquisa plástica cada vez mais pura. Contudo no ano seguinte, o pintor executou o painel "Tiradentes". Para promover o abstracionismo e, logo em seguida, a arte de tendência construtiva no Brasil era preciso acertar contas com a tradição moderna representada por Portinari. Nesse novo cenário, que coincidiria com a fundação da Bienal de São Paulo, Pedrosa não mediu esforços para consolidar a nova etapa da arte brasileira.

A seguir apresentamos um resumo dos capítulos da presente pesquisa:

O primeiro capítulo tratou das motivações que levaram Mário Pedrosa a defender, em 1933, uma arte proletária. Para isso foi necessário não menos o deslindamento das posições políticas de Pedrosa que a análise da conjuntura histórica e social do período. No plano internacional, ocorria tanto a ascensão do fascismo na Europa quanto a consolidação da vertente stalinista na URSS e, no plano nacional, os desdobramentos da Revolução de 1930 e a polarização mais acentuada da política brasileira devido sobretudo à pressão das camadas urbanas emergentes. Se a sociedade mobilizava-se para o embate entre esquerda e direita, também o meio artístico brasileiro 
foi incentivado a tomar posição frente às contingências e acontecimentos políticos da época. Nesse ínterim surgem, em São Paulo, como desdobramento da iniciativa da Semana de Arte Moderna, agremiações de artistas que visavam promover manifestações renovadas em arte. O Clube dos Artistas Modernos e a Sociedade Pró-Arte Moderna foram responsáveis pela produção de exposições de arte, apresentação de composições musicais, recitais, espetáculos de dança e debates de idéias. Por sua atividade perturbadora da ordem e de confronto com os hábitos e costumes da provinciana capital paulista, o CAM se destacou. Entre as atividades promovidas pela agremiação uma delas foi a conferência de Pedrosa sobre Käthe Kollwitz. Nesta conferência, o crítico apontava uma via nova para a arte brasileira.

A conferência de Pedrosa traduziu em palavras um sentimento, até certo ponto, generalizado de que os artistas tinham que participar mais ativamente do debate político brasileiro e se filiar à luta internacional do proletariado. A arte de Kollwitz era a melhor expressão de uma arte proletária, partidária e interessada na revolução. Por negar o conceito de humanidade para explicar a crise da sociedade, a arte tendenciosa de Kollwitz tinha muito mais humanidade que qualquer outra expressão artística habituada ao status quo. Se o proletariado usaria a crítica das armas para fazer a revolução, a arte proletária seria a arma da crítica contra as maze las do regime capitalista e a favor da revolução comunista. Em concordância com Leon Trotski, Pedrosa acreditava que a arte proletária servia à causa da revolução, mas não seria a expressão da sociedade futura. Como diria Trotski, na polêmica com os proletkultistas, não era possível imaginar que um esquema aplicado na denúncia das condições sociais reais servisse definitivamente para a arte, a fim de se extrair dele uma linha precisa de desenvolvimento artístico. Ocorrida a revolução tanto o proletariado se extinguiria como classe quanto a arte proletária deixaria de existir. Portanto, a nova arte da sociedade futura não seria nem proletária nem burguesa.

A luta contra o capitalismo e contra a ascensão do fascismo, em 1933, motivou muitos artistas a se posicionarem em favor da revolução comunista. Tanto no plano internacional como no nacional, as alternativas de convivência dos interesses da pesquisa puramente plástica com os debates políticos acirrados pareciam demasiado ingênuas, pois elas não enfrentavam o problema crucial da época que residia no campo político. Somente uma arte que ressaltasse a mensagem política poderia contribuir não só para a transformação profunda da sociedade, mas também para sua própria realização plena. Sendo assim, a posição de independência da arte moderna não provinha naquele 
momento de sua pesquisa formal, mas de sua capacidade em apresentar uma crítica consistente das bases e de todos os valores da sociedade, já que a luta da arte por sua liberdade de pesquisa passava primeiro pela recuperação de seu próprio sentido social. Em 1934, Pedrosa escreveu o ensaio "Impressões de Portinari”, em que a ênfase se deu na proposta, feita ao pintor, da passagem da tela para o mural.

O segundo capítulo abordou a trajetória de Pedrosa no exílio, 1937-1945. Nesse período, ocorreu a consolidação da arte realista e a crescente atuação e influência dos Estados Unidos no Brasil. Esses dois fatores influíram na mudança de enfoque sobre a função revolucionária da arte moderna. Assim como Leon Trotski, Pedrosa optou por uma arte que fosse revolucionária e que mantivesse por isso independência frente aos poderes constituídos. Em 1937, Trotski afirmava que o impulso contestador da arte não se subordinava às regras burocráticas, às fórmulas prontas e aos esquemas estabelecidos. Para ele, a arte em sua essência se opunha à realidade falseada ou apresentava um mundo que ainda não estava realizado. Essa era sua contestação da realidade. Se a crítica de Trotski endereçava-se originalmente à burocracia stalinista, ela de fato se estendia a toda forma de instrumentalização da arte. Avessa ao dirigismo cultural, implementado não somente na URSS mas também na Alemanha nazista e nos Estados Unidos, a arte lutava tanto contra a mistificação da realidade quanto contra a legitimação de um poder tirânico e desumano. Trotski pretendia indicar uma nova relação entre arte e política.

Em 1938, Breton chegava ao México para conversar com Trotski. Breton estava interessado em reaproximar os surrealistas da política comunista. Por sua vez, Trotski acolheu muito bem a iniciativa de Breton e tinha grande interesse pelo encontro com vistas a formar um agrupamento político e artístico consistente não somente na Europa, mas também nos Estados Unidos e no mundo. Trotski ansiava apresentar uma alternativa à arte dirigida e ganhar a confiança de intelectuais e artistas para uma nova revolução. No dia 25 de julho de 1938, o "Manifesto por uma arte revolucionária independente" foi publicado, com as assinaturas de André Breton e Diego Rivera, na Partisan Review. O manifesto de Trotski e Breton inspirou Mário Pedrosa a apresentar, no ensaio "Portinari - de Brodósqui aos murais de Washington" de 1942, uma alternativa possível para a continuidade e o desdobramento do trabalho plástico do Pintor brasileiro. Pedrosa sugeria a via da arte independente para Portinari. Tratava-se de combater o processo recente de instrumentalização das artes, evidenciado no plano internacional com o realismo socialista, a arte raciada nazista e o realismo democrático 
dos Estados Unidos e, no plano nacional, com a ênfase no realismo moderno de Portinari a serviço do Estado Novo. Os acordos diplomáticos entre Brasil e Estados Unidos e a missão cultural norte-americana selavam a marca populista na arte oficial do contine nte americano.

Ainda que houvesse ali uma tendência predominante do realismo, essa se tornava cada vez mais uma imposição para a construção necessária da identidade entre os Estados Unidos e os demais países do continente. Para os intelectuais norteamericanos que mantinham relações estreitas com o governo de Franklin D. Roosevelt, as diversas exposições e as pinturas murais de Portinari na Fundação Hispânica funcionavam não só como estreitamento necessário dos laços entre os Estados Unidos e o Brasil, mas também como forma de reafirmação e independência dos valores americanos frente à cultura européia. No meio artístico brasileiro, a propensão realista nas artes plásticas vinha sendo coroada pela passagem dos temas sobre o cotidiano de pessoas simples e sobre os arredores citadinos para a intensificação da temática social. Quando Pedrosa chegou ao Brasil, depois do exílio, e fundou o Vanguarda Socialista, em 1945, o problema fundamental de alguns daqueles artistas, e de outros mais, não se limitava à tentativa de resolução satisfatória entre a pesquisa formal e o conteúdo realista, mas à necessidade de se situarem no novo contexto mundial, cada vez mais polarizado entre as potências vitoriosas ao final da Segunda Guerra Mundial, e local, com a volta à atividade dos comunistas. Isso implicava mais do que um movimento em direção ao compromisso social das artes e, por sua vez, alguns artistas brasileiros enfatizaram uma escolha política. Entre esses artistas, o caso mais interessante de ser assinalado foi o de Cândido Portinari.

O terceiro capítulo analisou o retorno de Pedrosa ao Brasil: sua luta política e estética contra o Partido Comunista do Brasil e sua interpretação sobre o significado da obra de Portinari. De 1945 em diante, o crítico firmava sua posição em defesa da arte revolucionária independente e apontava a superação da arte realista pela tendência construtiva. Todos os intelectuais do Vanguarda Socialista, ao lado de Pedrosa, elaboraram a defesa da liberdade na arte brasileira seguindo a linha das conclusões do "Manifesto por uma arte revolucionária independente" e contra o estreitamento entre a arte e a mensagem política. Isso era necessário devido à utilização ideológica que se fazia da mensagem artística. Pedrosa não só decifrou as causas desse processo de normalização do realismo como também apontou novas vias de expressão plástica para a arte moderna. Era o princípio de uma reversão completa no direcionamento do valor 
atribuído à figuração brasileira. Como crítico de arte, Pedrosa foi um dos primeiros a indicar a superação da tradição moderna, baseada na figuração e representada por artistas consagrados como Portinari e Di Cavalcanti, e a sugerir a retomada e continuidade da arte de tendência construtiva no pós-guerra.

Em 1949, Pedrosa pôde avaliar o grau de acerto de suas considerações sobre a obra de Cândido Portinari, a partir do novo painel sobre a saga de Tiradentes. O Pintor tentava superar a conciliação entre os recursos expressivos da arte moderna e a via realista, por meio da ênfase na temática política. Mais ainda, a mensagem de suas obras - sobretudo as de temática histórica e social - era ressaltada com prejuízo da qualidade estética. Tudo o que fora motivo de entusiasmo para Pedrosa desfez-se, pois tanto a solução plástica proposta na obra 'Primeira Missa”, em 1948, não teve continuidade quanto voltava à carga o desenvolvimento do tema político como objetivo principal na pintura histórica sobre Tiradentes. Estava evidente a continuidade do interesse pela pintura de gênero que se adequava perfeitamente à subordinação da forma ao conteúdo. Portinari valia-se do expediente de compor o painel segundo sua avaliação política sobre o famoso tema da história nacional, enfatizando a idéia - defendida pelo PCB - de Libertação Nacional. Por seu turno, a crítica de Pedrosa ao painel de Portinari fez parte do processo de inauguração de um novo momento na arte moderna brasileira. Com a realização da primeira Bienal de São Paulo, em 1951, o aprimoramento e a consolidação da arte concreta foi conseqüência inevitável.

No quarto capítulo, Pedrosa aponta os novos fundamentos da comunicação em arte e a função revolucionária da arte de tendência construtiva. Fazia-se indispensável elucidar de que modo apenas uma arte independente e sem mensagem política explícita seria capaz de transformar o homem moderno e seu modo de sentir, agir e viver. As determinações práticas e utilitárias da sociedade, em que ele vivia, embotavam-lhe os sentidos e a sensibilidade. A arte de tendência construtiva pretendia arrancar o homem de seu cotidiano alienante e oferecer novas perspectivas do mundo. De modo geral, os escritos de Pedrosa, no final da década de 1940 e durante a década de 1950, realçaram a importância revolucionária da dimensão estética. Todo o esforço devotado pelos artistas construtivos na produção moderna visava ampliar a consciência dos homens, motivando neles a ação consciente. Essa mensagem da tendência construtiva só era possível devido à sua independência frente aos poderes constituídos e ao status quo, capaz de motivar uma alternativa política, econômica e social para o Brasil e para o mundo. Com sua especificidade e leis próprias, essa arte produziria uma revolução silenciosa. No mundo 
do pós-guerra, onde os ideários de transformação completa da sociedade eram substituídos pela prática reificadora e pelo pessimismo generalizado causado pela crença na falta de alternativas revolucionárias, a nova arte possibilitaria uma nova percepção do mundo, desenraizando o homem de seu cotidiano empobrecido e promovendo consciência transformadora. 
Capítulo 1. Mário Pedrosa e a arte como arma revolucionária 


\section{$\underline{\text { Os descaminhos da política na URSS e a ascensão do nazismo }}$}

A partir de 1923, o direcionamento da política russa no âmbito internacional foi responsável por quase todas as derrotas sofridas pelos movimentos operários. Isso se explica porque, entre 1923 e 1928, a linha de política externa do Comintern considerava encerrado o período revolucionário dos anos posteriores à Primeira Guerra. Ao adotar essa posição, os partidos comunistas exerceram invariavelmente função contrarevolucionária no mundo, como foi no caso da China e no das greves gerais na Inglaterra. Entretanto, a política de ziguezagues da URSS dava sua nova guinada em 1928, e Molotov, que substituiu Bukhárin como líder do Comintern, formulava a Teoria do Terceiro Período. Se o Segundo Período fora marcado pela política de Stálin visando à contenção dos limites da revolução comunista, o que agora se iniciava era a constatação da crise derradeira do capitalismo e do imperialismo. A mudança ex abrupto da política externa russa levou os partidos comunistas a uma nova fase de agitação em favor da luta revolucionária e da causa comunista.

Isaac Deutscher assinala que a nova orientação da Internacional Comunista e dos partidos comunistas era o resultado mecânico das transformações ocorridas na política interna da URSS. Sempre com vistas a contemplar os interesses da burocracia nacional, a Internacional Comunista tornava-se um mero apêndice das decisões do governo russo. Afinal ele: "Desde que Stálin iniciara a 'abertura para a esquerda' na União Soviética, a política do Comintern também mudou de direção, por uma transmissão automática de todo movimento e reflexo do partido russo. Já em seu VI Congresso, no verão de 1928, a Internacional começava a transplantar as suas palavras de ordem e prescrições táticas do padrão direitista para o ultra-esquerdista. (...) Enquanto nos anos anteriores o Comintern falava da 'estabilização relativa do capitalismo', agora diagnosticava o fim da estabilização e previa o colapso iminente e final do capitalismo. Era a essência da chamada Teoria do Terceiro Período, da qual Molotov (...) tornou-se o principal expoente. (...) Se até então o comunismo internacional estivera na defensiva, era o momento de passar à ofensiva e das lutas pelas 'reivindicações parciais e reformas', para a luta direta pelo poder."10

\footnotetext{
${ }^{10}$ DEUTSCHER, I. Trotski - O profeta banido. Rio de Janeiro: Civilização Brasileira, 1984, p. 47.
} 
Ao assinalar as mudanças na política russa, Deutscher seguia de perto as conclusões de Leon Trotski. A crítica, feita por Trotski, da teoria de Molotov e do posicionamento do Comintern referia-se, acima de tudo, à fraqueza de suas análises como resultado final do autoritarismo e da falta de debate sobre as tomadas de decisão política na URSS. Não era lícito o questionamento das análises ou a abertura de um debate interno sobre a linha política a ser adotada. A interdição do debate entre os membros dos partidos comunistas tornava-os meros cumpridores de ordens. Diz Deutscher: "Trotski mostrou que se era errado considerar o 'segundo período', durante o qual a Revolução Chinesa e a Greve Geral na Inglaterra haviam ocorrido, como de estabilização, era ainda menos realista prever o colapso iminente do capitalismo no 'terceiro período', e deduzir disso a necessidade de uma política exclusivamente ofensiva. O Comintern, disse ele, havia feito essa 'reorientação' mecanicamente, sem qualquer tentativa de elucidar o que havia de errado nas táticas antigas e sem qualquer debate autêntico e uma re-análise dos problemas. Proibidos de discutir os erros e acertos de sua política, os partidos comunistas estavam condenados a passar de um extremo para outro e trocar, quando mandavam, uma série de equívocos por outra."

A restrição de debates sobre a orientação tática na política, necessária para enfrentar a conjuntura e as perspectivas que se avizinhavam com a crise de 1929, contaminou a atuação dos partidos comunistas. O autoritarismo dos dirigentes não apenas freou as discussões sobre a política interna e impediu qualquer mudança na estrutura de poder da URSS, mas também isolou os partidos comunistas no plano internacional, onde eram condenadas as alianças com outros partidos da ala esquerda. A social-democracia passa a ser o grande inimigo dos comunistas. Deutscher comenta: "De acordo com essa 'linha geral', o Comintern também modificou sua atitude para com os partidos social-democráticos. Numa situação realmente revolucionária, dizia-se, esses partidos só poderiam colocar-se ao lado da contra-revolução e, portanto, não havia nenhuma razão para que os comunistas buscassem cooperação ou acordos parciais com eles. Assim como a burguesia estava lutando para salvar seu domínio com a ajuda do fascismo, assim como a era do governo parlamentar e das liberdades democráticas estavam chegando ao fim, e como a própria democracia parlamentar se estava transformando 'interiormente' no fascismo, os partidos socialdemocratas também se estavam tornando 'socialfascistas' - 'socialistas nas palavras e fascistas nos atos'.

\footnotetext{
${ }^{11}$ DEUTSCHER, I. Op. cit., p. 49.
} 
Como disfarçavam a sua 'verdadeira natureza' sob a parafernália da democracia e do socialismo, os social-democratas eram uma ameaça ainda maior do que o fascismo claro., $^{, 12}$

A condução interna do regime russo visava à perpetuação da burocracia no poder e tornava evidente seu desinteresse pelos movimentos operários internacionais. Essa displicência premeditada no tratamento das lutas operárias no mundo recaiu como responsabilidade dos partidos comunistas perante os tribunais da história. Se a política de direita do Segundo Período combateu as principais iniciativas revolucionárias até 1928, também o ultra-esquerdismo do Terceiro Período o fez. Mudava-se a orientação da direita para a esquerda sem mudar as práticas políticas que continuavam rígidas e instáveis. A política externa do Comintern, baseada na Teoria do Terceiro Período, seria seguida com determinação até a catástrofe da ascensão nazista na Alemanha. Diz Deutscher: "Essas noções e prescrições governariam a política de todos os partidos comunistas pelos cinco ou seis anos seguintes, quase que até à época da Frente Popular, durante todos os fatídicos anos da Grande Depressão, da ascensão do nazismo, do colapso da monarquia na Espanha e outros acontecimentos nos quais a conduta do partido comunista teve importância crucial." ${ }^{\text {,13 }}$

Em outubro de 1929, ocorreu o crack na Bolsa de Nova York. A crise econômica assolou o sistema econômico internacional e trouxe como conseqüência a deterioração da situação social em vários países. Do dia para a noite, milhões de trabalhadores perderam seus empregos. Em 1930, na Alemanha o chanceler Herman Müller da coalizão social-democrata é obrigado a renunciar. Com a dissolução do parlamento, novas eleições são realizadas e inicia-se o período de crise da democracia parlamentar. Os partidos tradicionais da política alemã, o Social-Democrata e o Deutsch-Nazionale, perdem terreno nas eleições para o Partido Comunista e para o Partido Nazista. Aterrorizada com os seis milhões e meio de votos para Hitler, a social democracia alemã difunde em todo o país uma campanha sistemática contra o nazismo. Por sua vez, o Partido Comunista Alemão resolve minimizar a ameaça nazista e rechaça a campanha da socialdemocracia, convencido de que os quatro milhões e meio de votos recebidos em 1930 iriam se multiplicar nas próximas eleições.

Em meio ao crescimento vertiginoso do nazismo, o Partido Comunista Alemão considerou a vitória de Hitler como provisória e desprovida de base para se sustentar.

\footnotetext{
12 DEUTSCHER, I. Op. cit., p. 48.

${ }^{13}$ Idem, ibidem, p. 49.
} 
Seu principal alvo de críticas continuava a ser a social-democracia e os demais grupos de esquerda. Em 1931, Ernest Thaelmann envia uma carta ao Comintern em Moscou regozijando-se da quantidade de votos recebidos pelos comunistas nas eleições e, ao mesmo tempo, ataca os alardes da socialdemocracia sobre a ascensão política de Hitler. Deutscher comenta: "Vários meses depois, quando as cidades da Alemanha já haviam experimentado o terror da tropa de choque de Hitler, Ernest Thaelmann, líder do Partido Comunista, disse (...): 'Depois de 14 de setembro, seguindo-se ao êxito sensacional dos nacional-socialistas, seus partidários, em toda a Alemanha, esperavam grandes coisas deles. Nós, porém, não nos deixamos enganar pelo pânico que se revelava ... na classe trabalhadora, pelo menos, entre os seguidores do Partido Social-Democrata. Afirmamos, sóbria e seriamente, que o 14 de setembro foi, de certa forma, o melhor dia de Hitler, e depois dele não haverá dias melhores, e sim piores'. A Executiva do Comintern endossou tal opinião, congratulou-se com Thaelmann e confirmou a sua política do Terceiro Período, que levou o Partido Comunista a rejeitar a idéia de qualquer coalizão socialista-comunista contra o nazismo."14

No final de 1929, Trotski já demonstrava apreensão com a ascensão dos nazistas e, em 1930, ele insistia na formação de uma "frente única" de social-democratas e de comunistas alemães contra Hitler. No entanto, sua proposta deparou com oposições ferrenhas de ambos os lados. Por um lado, o Partido Comunista não via nenhuma diferença entre o fascismo e as democracias burguesas; por outro, o Partido Social Democrata acreditava que, caso os nazistas alcançassem o poder, seria possível fazer um acordo institucional com Hitler e preservar o Parlamento. Até 1932, os nazistas não tinham dado sinais claros sobre a tentativa de putsch. Além disso, os social-democratas mantinham há vários anos uma política frontalmente anticomunista, o que não facilitou o acordo com o PCA. O ano fatídico de 1933 representou um golpe duro e decisivo contra a tática da política externa russa. Pode-se dizer que a falência do ultraesquerdismo "de fachada" do Comintern, propugnado pela Teoria do Terceiro Período ocorreu de forma emblemática na época em que Hitler foi nomeado chanceler do Reichstag e, em seguida, extinguia as atividades do Parlamento alemão.

Naqueles anos, Mário Pedrosa lutou ativamente contra o nazismo. Entre 1927 e 1929, ele esteve em Berlim, participou de várias passeatas contra os nazistas organizadas pelo Partido Comunista Alemão e entrou em contato com Pierre Naville na

\footnotetext{
${ }^{14}$ DEUTSCHER, I. Op. cit., p. 138. (parênteses nossos).
} 
França $^{15}$. Ao chegar à Alemanha em 1927, Pedrosa adoeceu e desistiu de seguir viagem para Moscou, pois as oposições ao Comintern estavam sendo sistematicamente expurgadas da política. Com a expulsão de Trotski da URSS em 1928, muitos militantes dissidentes da linha oficial do PC empenharam-se na formação de uma oposição de esquerda, que agisse como grupo fracional nos partidos comunistas e na orientação da Internacional Comunista a fim de revitalizar o caráter internacionalista da revolução comunista. A partir de 1928, Pedrosa manteve informados os militantes dissidentes da linha dominante no Partido Comunista do Brasil sobre a formação de uma oposição combativa de esquerda ao Partido Comunista da URSS e sobre as articulações que Naville fazia na França para a formação de uma tendência oposicionista no Partido Comunista Francês.

Edgard Carone diz que "logo após 1929, Ligas Comunistas (internacionalistas) começam a ser fundadas na maior parte dos países capitalistas, dirigidas por militantes que discordam da linha oficial da Internacional Comunista (Moscou). Em 1930 realizase uma conferência de todas as oposições da esquerda mundial, que reúne delegados franceses, americanos, alemães, belgas, espanhóis, tchecos, grupo judaico francês etc. Sua intenção é definida por um editorial do Boletim de oposição $\left(\mathrm{n}^{\circ} 1\right)$ : 'tal como a constituição de frações de oposição não significava a criação de segundos Partidos [isto é, novos partidos comunistas], também a união destas frações nacionais não significa que nós nos orientemos para a criação de uma IV Internacional. A posição de esquerda considera-se como uma fração do comunismo internacional e age como tal (...) $\mathrm{O}$ objetivo da oposição é o renascimento da Internacional Comunista sobre bases leninistas.", 16

Quando Pedrosa voltou ao Brasil, em agosto de 1929, sua atuação política foi decisiva para a fundação de um grupo de oposição no PC. Segundo José Castilho M.

\footnotetext{
${ }^{15}$ No início de 1927, Mário Pedrosa publicou os seguintes artigos sobre artes: "Mário de Andrade, escritor brasileiro", 13-03-1927, e "Beethoven: artista-herói da revolução", 23-03-1927, ambos no jornal paraibano A União. Desistindo do emprego como agente fiscal do Estado da Paraíba, Pedrosa foi para São Paulo e assumiu a direção do movimento Socorro Vermelho. Credenciado por Astrogildo Pereira, Pedrosa seguiu viagem para ingressar na Escola Leninista de Moscou. Na Alemanha, escreveu o artigo: "A rebelião romântica e o espírito prussiano", que trata das condições de surgimento e evolução da arte alemã. Pedrosa indicaria que a volta à natureza propugnada pelos artistas da Worpswede e a rebelião subjetiva dos expressionistas eram reações contra o maquinismo intenso vivido nas cidades e a alienação do trabalho na sociedade alemã. No ano de 1929, Pedrosa publicou o artigo "Villa-Lobos et son peuple" na Revue Musicale.

${ }^{16}$ CARONE, E. A república nova (1930-1937). São Paulo: Difel, $2^{\text {a }}$ ed., 1976, pp. 268-269. Para um estudo sobre a atuação política de Mário Pedrosa no final dos anos 20 e início de 30: MARQUES NETO, J.C. Solidão revolucionária: Mário Pedrosa e a origens do trotskismo no Brasil. Rio de Janeiro: Paz e Terra, 1993. Ver também: ABRAMO, F. \& KAREPOVS, D. Na contracorrente da história: documentos da liga comunista internacionalista (1930-1933). São Paulo: Brasiliense, 1987.
} 
Neto, essa tarefa não foi fácil e apenas se concretizou entre o final de 1929 e o início de 1930, pois assim como em outros países: "Reunir as diversas frações que se identificaram de um modo ou de outro com os argumentos da Oposição de Esquerda russa foi um longo caminho que, de fato, só começou a se concretizar em princípios dos anos 30. Nesses anos que precedem o I Encontro Internacional da Oposição de Esquerda, a não-organicidade do movimento contribuiu para a dispersão. (...) No Brasil, o quadro não foi diferente. (...) Foi nestas circunstâncias que a ousadia política e intelectual de Mário Pedrosa, somada à sua experiência na Alemanha e na França, nos anos de rompimento de Trotski e Stálin, foram fundamentais nos primeiros passos para se constituir um agrupamento que, enfrentando a acusação de trotskismo, encarou o duro embate político e ideológico contra o PC e contra as classes dominantes. Esse grupo levou o nome de Grupo Comunista Lenine (...)."17

\footnotetext{
${ }^{17}$ MARQUES NETO, J. C. "O jovem intelectual e os primeiros anos de militância socialista" In: Mário Pedrosa e o Brasil. (org.). São Paulo: Fundação Perseu Abramo, 2001, pp. 93-94. Marques Neto comenta ainda que, nos anos subseqüentes, as diferenças teóricas entre o GCL e o PCB se aprofundaram e "os militantes originários do minúsculo Grupo Comunista Lenine criaram mais três organizações sob a liderança de Mário Pedrosa: Liga Comunista (Oposição), 1930/31, Liga Comunista Internacionalista, 1931/35, e Partido Operário Leninista, 1936. Em todos eles, o trabalho se deu contra a corrente, primeiramente buscando transformar o próprio PC e, num segundo momento, procurando criar uma nova Internacional." Idem, ibidem, p. 97. Segundo Edgard Carone, o grupo formado por Pedrosa, "originou-se de uma célula expulsa coletivamente do Partido na região do Rio, alegando a direção do PC questões disciplinares. Constituído na maior parte de operários gráficos, o grupo (...) começou a editar Luta de Classe, jornal que, depois, se tornou órgão da Liga Comunista. Mas só após a derrocada da República Velha, (outubro de 1930), em São Paulo, já sob a interventoria de João Alberto, foi fundada a Liga Comunista Internacionalista, seção da Oposição Internacional de Esquerda, em 21 de janeiro de 1931, comemorando a data da morte de Lenine. A sessão de fundação realizou-se na Associação dos Empregados do Comércio, na Rua Libero Badaró, presentes entre outros: Aristides Lobo, Benjamin Péret, Manuel Medeiros, Mário Pedrosa, Lívio Xavier, Salvador Pintaúde, João Mateus, intelectuais e operários." CARONE, E. A república nova (1930-1937). São Paulo: Difel, 2ª ed., 1976, p. 270.
} 


\section{$\underline{\text { A luta contra o integralismo e contra a ideologia da colaboração de classes }}$}

Com a revolução de 1930, os militantes ligados a Mário Pedrosa e estabelecidos, em sua maioria, em São Paulo combateram tanto o Partido Comunista do Brasil como a política trabalhista de Vargas e os movimentos fascistas. Para Carone, mesmo que o trotskismo seja, no plano ideológico, o oposto do stalinismo, pois "este é acusado de terse tornado 'burocrático' e 'anti-internacionalista', isto é, autoritário e voltado ao ‘socialismo em um só país' (...) (e que), por sua vez, Leon Trotski representa a herança mais revolucionária de Marx e Lenine, defendendo a idéia de revolução mundial, ou 'revolução permanente', e o democratismo revolucionário, as diferenças ideológicas que se acentuam na Rússia, na década de 1920, não impedem que as duas tendências sejam marcadas por maneiras de ser e agir comuns, pois não é o formalismo da separação e das palavras de ordem que vão diferenciar as atitudes, que estão marcadas pela mesma tradição revolucionária e organização rígida." ${ }^{18}$ Portanto, pode-se dizer que mesmo não tendo objetivos revolucionários comuns, mas com uma forma de organização política parecida, no alvorecer dos anos trinta, o PCB e o grupo de Pedrosa se uniram na em torno da luta comum contra a ameaça integralista.

Os efeitos da crise do café e da crise política nacional fizeram-se sentir, no início dos anos trinta, principalmente em São Paulo, que foi o palco das grandes transformações do país. Em depoimento, Pedrosa comentou: "Da década de vinte para a de trinta, grandes acontecimentos políticos sacudiram o Brasil, de Sul ao Norte; e São Paulo se tornou o ponto nevrálgico da revolução, embora o poder central continuasse no Rio, as forças sublevadas viessem do Rio Grande do Sul, com os provisórios, de Minas e do Nordeste. São Paulo foi ocupada militarmente, com um interventor militar de fora, um autêntico 'tenente'. Em nenhum Estado da Federação, o processo de transformação política e social foi mais acentuado do que na terra do Piratininga. As convulsões ali foram maiores, e terminaram com a revolta da burguesia e pequena burguesia paulista, em nome da reconstitucionalização geral e da autonomia do Estado. A divisão de classes já num sentido moderno foi maior em São Paulo. Se Higienópolis, o bairro

\footnotetext{
${ }^{18}$ CARONE, E. A república nova (1930-1937). São Paulo: Difel, 2a edição, 1976, p. 274.
} 
aristocrático, era hostil ao novo poder revolucionário, o Brás proletário era favorável. E já lhe manifestava sua ingênua simpatia."19

A Aliança Liberal, formada por políticos gaúchos e mineiros, questionava a vitória do candidato paulista Júlio Prestes sobre o candidato derrotado Getúlio Vargas no pleito presidencial de março de 1930. Como explica Edgard Carone, a crise política foi resultado de uma divergência momentânea entre as oligarquias nacionais: "Desde a proclamação da república, com alguns períodos de exceção, os fazendeiros de café de São Paulo e Minas tinham controle sobre o governo federal. Os partidos dominantes, os famosos PRs, eram em todo Brasil de composição social e ideológica predominantemente agrícola. $\mathrm{O}$ apoio da burguesia, em parte saída da oligarquia, como era o caso de São Paulo, nunca representou um desafio a esta preponderância e em momento algum as teses 'liberais' da dissidência de 1926 (Partido Democrático) puseram em xeque a solidez daquelas agremiações. Somente quando Antônio Carlos é preterido por Washington Luís, é que Minas, Rio Grande do Sul e Paraíba, pelas vozes das suas oligarquias agrícolas dominantes, rebelam-se contra seus companheiros."20

Em maio de 1930, Vargas lançava um manifesto denunciando fraude na eleição. Entretanto, tudo parecia se encaminhar para uma nova acomodação no consenso generalizado de manutenção da ordem até o momento em que João Pessoa foi morto na cidade de Recife. Visto que o presidente Washington Luís apoiava na Paraíba os líderes políticos responsáveis pelo assassinato, encontrava-se um pretexto para a intervenção armada. Se a antiga política nacional dependia apenas do acordo entre oligarquias regionais, agora outros setores sociais eminentemente urbanos participavam da cena política. Para Edgard Carone, ainda que a dissensão momentânea entre as oligarquias fosse o estopim para a crise política, a revolução foi resultado da crise econômica aliada à ao aumento de importância política das classes urbanas - burguesia, pequena burguesia e proletariado: "Dá-se então o que um europeu definiu como a 'lei fundamental das revoluções', isto é, a conjunção destes dois fatores: as camadas superiores não podem viver e governar como antigamente, devido a uma crise governamental que enfraquece o governo e as camadas inferiores (aqui classe média e operária) têm consciência da impossibilidade de viver como antigamente e reclamam mudanças. A cisão da oligarquia dominante, que leva a parte dissidente a aliar-se com o

\footnotetext{
${ }^{19}$ PEDROSA, M. "Entre a Semana e as Bienais" In Mundo, homem, arte em crise. (org. Aracy Amaral). São Paulo: Perspectiva, 1986, p. 275.

${ }^{20}$ CARONE, E. Da esquerda à direita. Belo Horizonte: Oficina de Livros, 1991, p. 186.
} 
tenentismo revolucionário, e o descontentamento das camadas populares (...) fazem o 3 de outubro de 1930."21

Coube à oligarquia dissidente dirigir a revolução de 1930, porém ela o fez com a participação decisiva dos tenentes. Por um lado, políticos da Aliança Liberal tais como Borges de Medeiros e Antônio Carlos trabalhariam para a adesão dos principais comandantes do exército, por outro, entusiasmados com o apelo de Vargas para a "reconstrução nacional",22, jovens oficiais do exército iniciaram marcha em direção ao Rio de Janeiro com o apoio das tropas da Paraíba, do Rio Grande do Sul e de Minas Gerais. Além desses grupos, aprovaram a revolução: constitucionalistas, representados por amplos setores das camadas médias e por políticos do Partido Democrático de São Paulo, que desejavam a preservação das instituições, a aprovação de uma nova constituição e eleições livres; militares de alta patente, que exigiam mais verbas para as forças armadas; cafeicultores paulistas descontentes com a baixa dos preços, exigindo mais créditos para a plantação e um programa de proteção ao café; políticos que até aquele momento estavam na oposição e não tinham compromissos ideológicos claros. Em novembro de 1930, Getúlio Vargas era empossado presidente do Governo Provisório do Brasil, dez dias depois da deposição de Washington Luís.

Como resultado da revolução, os tenentes e a oligarquia política disputariam o poder nos dois anos seguintes. A burguesia desejava apenas uma reforma política e o tenentismo, mudanças sociais. Edgard Carone depreendeu: "Mas esta facção da oligarquia, cuja composição se torna com o correr do tempo acentuadamente urbana, não consegue o poder com a revolução. Os tenentes afoitamente dele se apossam e é contra isto que se vai lutar. Primeiro - caso de São Paulo e Rio Grande do Sul -, tentase envolver os seus atuais interventores, ao mesmo tempo que se faz pressão sobre Getúlio. Depois, é rompimento com o tenentismo e a aproximação com os 'carcomidos' e 'corruptos', isto é, aqueles grupos oligárquicos que fazia pouco tinham sido apeados do poder. (...) Mesmo derrotadas militarmente, as oligarquias sabiam que o slogan de ‘constitucionalização' seria a sua vitória. (...) A vitória também resulta no predomínio da oligarquia urbana sobre a velha camada rural. Esquecendo seu programa 'liberal' e as 'liberdades' exigidas até então, a nova oligarquia vai caminhar para a 'sua' ditadura,

\footnotetext{
${ }^{21}$ CARONE, E. Op. cit., p. 187.

${ }^{22}$ No final de 1929, Getúlio Vargas tem um encontro secreto em Porto Alegre com Luis Carlos Prestes, na época, um dos líderes mais influentes dos tenentistas, para obter apoio na revolução de 1930. Segundo o acordo que não foi cumprido por Vargas, Prestes tornar-se-ia Chefe do Estado-Maior. Para um estudo mais completo sobre as origens e as tendências políticas do tenentismo: SODRÉ, N. W. História militar do Brasil. Rio de Janeiro: Civilização Brasileira, 1965, pp. 237-251.
} 
tentando pela Lei de Segurança Nacional refrear os movimentos tenentistas e operários.",23

O desfecho do processo político aberto com a revolução de 1930 foi o golpe de Getúlio Vargas em 1937. Entretanto, no início do Governo Provisório, tanto tenentes como operários divisaram a possibilidade de renovação da política brasileira com a derrubada da Velha República. Por um lado, os operários retomaram suas atividades sindicais e políticas, impulsionados pela queda do governo de Washington Luis no qual a questão social era considerada "caso de polícia”. Por outro, os tenentes se organizaram em legiões revolucionárias de tendência "liberalesquerdista" e tinham como propósito a formação de um "partido-Estado" à moda dos estados totalitários. A fim de se fortalecerem perante a oligarquia política no governo, os tenentes tentaram se aproximar dos operários com o compromisso de atender suas reivindicações e com a inclusão de direitos políticos representativos para os sindicatos durante a eleição de $1933 .^{24}$ Contudo, os tenentes, como interventores nos estados, assumiram uma postura quase sempre conciliatória entre operários e patrões. Devido à sua indefinição ideológica, o tenentismo não conseguiu se aproximar das classes trabalhadoras e seu movimento perdeu definitivamente influência no governo para as oligarquias políticas que exigiram a constitucionalização do País.

Se a Aliança Liberal era composta de políticos locais sequiosos em tomar o lugar antes ocupado por uma diminuta elite política da Velha República, logo em seguida esse grupo perdeu visibilidade no plano nacional para novos movimentos políticos organizados e de orientação ideológica evidente. Os últimos serviram como forças catalisadoras para o tenentismo, para a reorganização política da classe média e para o proletariado no início de trinta. Diz Carone: "O movimento operário tivera nos anos posteriores a 1930 grande expansão. O movimento sindical e partidário, as greves e reivindicações faziam-se em clima de exaltação, multiplicando-se as tendências. A aproximação tentada pelas legiões (revolucionárias) fracassara e será a aglutinação de todas as tendências dentro da Aliança Nacional Libertadora que representará perigo latente para a burguesia. De 1930 a 1932, (...) o movimento operário aparece em plena vitalidade: aparentemente dominado pelo novo Ministério do Trabalho, mal é notado como força política pelos teóricos burgueses e da pequena burguesia. ${ }^{25}$ Para além das

\footnotetext{
${ }^{23}$ CARONE, E. Op. cit., p. 187.

${ }^{24}$ Cf. CARONE, E. A república nova (1930-1937). São Paulo: Difel, $2^{a}$ edição, 1976, pp. 304-329.

${ }^{25}$ CARONE, E. Da esquerda à direita. Belo Horizonte: Oficina de Livros, 1991, pp. 187-188.
} 
ações do proletariado, parte da classe média urbana participou do movimento político de direita denominado integralismo. Com a reconstitucionalização, tanto o operariado como as classes médias se organizaram para o novo cenário político.

No começo de 1931, Mário Pedrosa participou da fundação da Liga Comunista Internacionalista, fixou residência em São Paulo e começou a trabalhar para o jornal

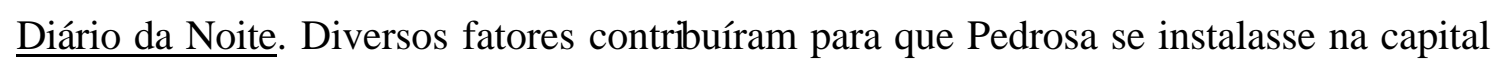
paulista, entre eles: a existência de um grupo de militantes e amigos que possuíam mais afinidade com suas idéias e a aproximação efetiva dos trotskistas com o sindicato dos trabalhadores gráficos. Nessa época, a interventoria de João Alberto marcava diferença em relação à ação dos tenentistas em outros estados. Em novembro de 1930, depois de um acordo com Luis de Barros, ele legalizou a atividade política do PCB no Estado. O grupo de Pedrosa condenou a ação, pois acreditava que o partido comunista deveria ser convalidado pela mobilização e pressão das massas trabalhadoras e não pelo acordo com a pequena burguesia no poder. Diz Carone: "os trotskistas mostram o erro (...) e as conseqüências da aproximação entre tenentismo e comunismo: ‘(...) Uma simples ordem assinada por um funcionário do Estado... não tem outro significado que o de uma mistificação, um processo barato para enganar os trabalhadores, porque muito mais forte do que as boas intenções de que pudesse estar animado esse funcionário é a força de classe da burguesia, e esta, principalmente em virtude do lastimável estado de desorganização em que se encontra o proletariado, não pode ter interesse direto em conceder à última senão as liberdades mais elementares.",26

O que Pedrosa e seu grupo tentavam mostrar é que a aliança propugnada pelo partido comunista com a pequena burguesia no governo favorecia apenas à burguesia e traía os interesses imediatos do proletariado e desnorteava as fileiras operárias, organizadas em sindicatos, sobre qual deveria ser o caminho político a ser seguido e sobre quem eram seus legítimos representantes. Temia-se que a aceitação da política de concessões desestabilizasse ainda mais os sindicatos e fornecesse suporte para uma campanha do governo contra os operários. Essas indicativas de situação anteviram o que havia por trás da contemporização e das concessões do Ministério do Trabalho em favor da causa operária. No ano de 1931, o Governo Provisório de Vargas consumou sua

\footnotetext{
26 CARONE, E. A república nova (1930-1937). São Paulo: Difel, 2a edição, 1976, pp. $276-277$. (parênteses nossos). Diz Thomas Skidmore: "Para as classes trabalhadoras, o Governo Provisório criou (...) um novo Ministério do Trabalho, Indústria e Comércio, formado - anotação interessante sobre o Brasil de 1930 - através do desmembramento de uma parte do Ministério da Agricultura”. SKIDMORE, T. Brasil: De Getúlio a Castelo. Rio de Janeiro: Paz e Terra, 1982, p. 33. (parênteses nossos).
} 
política para enfraquecer a atividade sindical e, por conseguinte, controlar os trabalhadores de todo o país. O esforço governamental constante de estabelecer leis e de fazer valer a racionalização - supostamente neutra - das relações entre capital e trabalho servia apenas para reafirmar a vigência triunfante do primeiro em detrimento dos interesses do último, ambos a serem supervisionados pelo Estado.

Em novembro de 1930, Getúlio Vargas e a coalizão dos tenentistas e da oligarquia dissidente procuraram atender reivindicações dos operários e dos camponeses, sendo assim foram decretadas várias leis sociais. Sua política tinha caráter aparentemente dúbio, pois ora favorecia os trabalhadores, ora criava instrumentos para combatê-los. De forma mais sistemática do que as interventorias dos Estados, o Governo Provisório por meio de seu Ministério dos Negócios do Trabalho, Indústria e Comércio difundiu a ideologia da conciliação de interesses das classes. Explica Carone: "No discurso de posse, Lindolfo Collor fala que o seu 'programa é a ação. Vamos começar a agir'. Mas, o que se dá, na verdade, é uma política de aproximação com industriais e classes dominantes e cerceamento progressivo das liberdades operárias. Numa série de discursos posteriores, o novo ministro tenta vulgarizar o seu pensamento e dar idéia de seu espírito democrático. Na sua fala do Rotary Club do Rio de Janeiro, afirma aos industriais e comerciantes que, em primeiro lugar, existe o interesse nacional, porque a 'regularização jurídica das relações entre o capital e o trabalho obedecerá, pois, entre nós, ao conceito de colaboração de classes.",27

A política do Ministério do Trabalho consistia em que qualquer reivindicação dos trabalhadores deveria ser objeto de apreciação dos órgãos patronais representantes do setor em que se dava o litígio para um possível acordo. De fato, essas tentativas do Ministério para coordenar empregados e patrões, capital e trabalho serviam como forma disciplinar e instrumento de limitação dos avanços trabalhistas. Em 19 de março de 1931, é decretada a Lei de Sindicalização. Edgard Carone comenta: “(Essa lei), chamada por Lindolfo Collor de 'a primeira iniciativa sistemática no sentido da organização racional do trabalho, em nosso país', não passa de uma adaptação da Carta del Lavoro, de Mussolini. Nela há separação entre os sindicatos econômicos, e os sindicatos profissionais, não havendo, naturalmente, mais atividade política nos sindicatos. Além disso, só é reconhecido um sindicato de cada profissão, deixando de existir a antiga pluralidade sindical; e o Ministério intervém e controla a vida financeira

\footnotetext{
${ }^{27}$ CARONE, E. Op. cit., p. 132.
} 
do sindicato. Como diz um velho militante da época, Everardo Dias, o que se tem são 'sindicatos não garantidos pelo Estado, mas a serviço do Estado, tutelados pelo Estado, com administração escolhida adrede pelas autoridades e não por assembléias democráticas, livres de qualquer interferência estranha'. (...) A nova lei é combatida por operários e patrões até que a Constituição de 1934, estipula no artigo 120, parágrafo único, que a 'lei assegurará a pluralidade sindical e a completa autonomia dos sindicatos.",28

Depois da exoneração de Lindolfo Collor, as duas gestões seguintes do Ministério do Trabalho - a de Salgado Filho, entre abril de 1932 e julho de 1934, e a de Agamenon Magalhães, entre julho de 1934 e novembro de 1937 - foram marcadas pelo tom paternalista no tratamento dos "humildes" e pela difusão da ideologia anticomunista. De forma geral, o Ministério empenhava-se em transmitir para os operários a imagem do Governo Provisório como construtor de um país moderno em que a classe trabalhadora ocuparia posição de relevo. Essa retórica governamental sobre o tratamento especial concedido à questão social contribuía para a formação da opinião favorável das massas operárias e para o controle dos sindicatos. Como observa Carone, o discurso do Ministro Salgado Filho dá prova disso: “As reclamações (dos operários) devem ser ouvidas nos gabinetes”. E prosseguindo paternalisticamente adverte que “deveis ter sempre presente que os vossos interesses só serão convenientemente resguardados, só poderão ser concedidos aqueles benefícios a que vosso labor faz jus, por meio de uma exposição polida, uma reclamação moderada. Junto ao ministro (...), explicareis a causa do desagrado, mostrareis a causa, o prejuízo oriundo deste ou daquele ato". E, para evitar malentendidos, Salgado Filho adverte contra os “estranhos... que se vos apresentam como patronos, partidários da agitação como

\footnotetext{
${ }^{28}$ CARONE, E. Op. cit., pp. 146-147. A lei de Sindicalização regulava os direitos das classes patronais e operárias, porém, segundo Edgard Carone: "(ela também estabelecia) entre outras obrigações (a) “abstenção, no seio das organizações sindicais de toda e qualquer propaganda de ideologias sectárias, de caráter social, político e religioso, bem como de candidaturas a cargos eletivos estranhos à natureza e finalidade das associações". Os estatutos dos sindicatos devem ser aprovados pelo Ministério do Trabalho. Haverá direito de formar, nos Estados, uma federação regional e estas formarem uma Confederação Brasileira do Trabalho. "Ainda como órgãos de colaboração com o Poder Público, deverão cooperar os sindicatos... por conselhos mistos e permanentes de conciliação e julgamento, na aplicação das leis que regularem os meios de dirimir conflitos suscitados entre patrões, operários ou empregados". (...) Se houver cisão de um sindicato, "será reconhecido o que reunir dois terços da mesma classe". Nenhum operário pertencente a sindicato reconhecido pelo Ministério do Trabalho "poderá, sob pena de ser excluído, fazer parte de sindicatos internacionais."” Idem, ibidem, p. 146.
} 
recursos para evitar vossos males (...). Deveis acautelar-vos dessa infiltração perniciosa." 29

Frente ao movimento operário e sua atividade sindical, o intento do grupo de Pedrosa era o de lutar contra a ideologia da conciliação de classes e a favor de uma coligação dos sindicatos contra os governantes e a burguesia: "O que (os trotskistas) pedem (1931) é 'unidade de toda a organização sindical revolucionária', em São Paulo, mas, 'dentro da Confederação Geral do Trabalho do Brasil, que é o único organismo operário central', e que tem lutado revolucionariamente a favor do operariado; 'unidade para a luta contra a burguesia', luta contra as 'tapeações do governo, por intermédio do Ministério do Trabalho, que manobra para enganar as massas trabalhadoras, desviá-las do terreno da luta de classe, mergulhá-las no charco do colaboracionismo e do reformismo'; propor Congresso Regional Sindical de São Paulo, com representantes dos sindicatos de todas as facções, até dos anarquistas, "para concretizar o problema da unidade e eleger a direção definitiva da futura federação Sindical Regional, aderente a CGTB"”. O ponto alto na política de coligação de sindicatos foi o ano de 1934, "no momento das eleições estaduais para a Assembléia Estadual Constituinte: esta frente única sindical - trotskistas, anarquistas e até comunistas - leva à ampliação das reivindicações operárias'.,30

Em 9 de julho de 1932, estourou a Revolução Constitucionalista em São Paulo. Nesse ano, Mário Pedrosa fundou a Casa Editora Unitas, responsável pela publicação de vários textos marxistas. ${ }^{31}$ Entre eles, é preciso destacar a tradução e o prefácio feito por Pedrosa de um conjunto de ensaios de Trotski sobre a crise alemã, intitulado "Revolução e contra-revolução na Alemanha". As ações urgentes da Liga Comunista Internacionalista no Brasil eram a reunião dos movimentos operários para a revolução comunista e a organização da luta contra o fascismo. Por um lado, o cenário político internacional começava a ter repercussão mais pungente aqui e ocorria um realinhamento coetâneo das diversas tendências políticas inscritas na sociedade brasileira, por outro, agravava-se a luta encarniçada entre as oligarquias políticas e o tenentismo. Como se sabe, a vitória dos tenentes na revolução de 1932 marcou seu

\footnotetext{
${ }^{29}$ Idem, ibidem, pp. 136-137.

${ }^{30}$ Continua Carone: os trabalhadores conquistam a jornada de oito horas, as férias, etc., "[conquistam] [...] novas leis sociais (salário mínimo regulamentado para cada profissão), seguro contra invalidez, luta pela gratuidade e laicidade do ensino, nacionalização do serviço público, dos bancos, das terras, etc." CARONE, E. A república nova (1930-1937). São Paulo: Difel, $2^{\mathrm{a}}$ edição, 1976, pp. 275-276. (colchetes nossos).

${ }^{31}$ Cf. Idem, ibidem, pp. 278-279.
} 
declínio político e ascensão de movimentos ideologicamente mais definidos e mais organizados. Dentre esses movimentos políticos é preciso destacar a consolidação das ações dos comunistas ligados ao PCB - que em 1935 fundariam com Prestes a Aliança Nacional Libertadora - e o agrupamento das facções de direita, que, entusiasmadas com a ascensão dos fascistas na Europa, começaram a se organizar num movimento político - Ação Integralista Brasileira - mais coeso para tomar o poder. ${ }^{32}$

O integralismo passava a ser reflexo da reação das classes governantes contra as conquistas e a movimentação política da classe operária. Em meados de 1932, o Manifesto da Ação Integralista Brasileira já estava pronto, porém a eclosão dos combates da Revolução Constitucionalista adia para o mês de outubro seu pronunciamento por Plínio Salgado. Os dois princípios básicos do documento são a idéia de união nacional e a de cultura brasileira, sob os auspícios de um Estado Forte. Da seguinte forma, a ideologia integralista é definida no Manifesto: "Deus dirige os destinos dos povos. O homem deve praticar sobre a terra as virtudes que o elevam e aperfeiçoam. O homem vale pelo trabalho, pelo sacrifício em favor da família, da Pátria e da sociedade." Porém a subordinação do homem não deve impedi-lo de ver que "a riqueza é um bem passageiro, que não engrandece ninguém", e que bmens e classes "podem e devem viver em harmonia". (...) Acima da superioridade particular de cada um, existe a "suprema finalidade", que é um "pensamento profundamente brasileiro, que vem das raízes de nossa história". O que é preciso é tornar a nação "organizada, una, indivisível, forte, poderosa, rica, próspera e feliz": daí ser necessário "união íntima e perfeita de seus filhos e o término das divisões dos Estados, dos partidos, das classes etc.",33

\footnotetext{
${ }^{32}$ Em 1932, Plínio Salgado se afastou de líderes do movimento tenentista para lançar o Manifesto de Outubro ( 2 de outubro) e, por sua vez, João Alberto manteve contato com autoridades do governo fascista de Mussolini. Na revista Hierarquia I, n ${ }^{\circ}$, março e abril de 1932, Plínio Salgado descreve seu encontro com Benito Mussolini: “Numa tarde de junho, depois de ter visto toda a Itália Nova, depois de a ter julgado com todo o rigor, eu me vi, no Palácio Veneza, frente a frente com o gênio criador da política do Futuro". "Era Mussolini. Esse homem criara a Nova Itália...." "Lembro-me bem das palavras de minha despedida. Mussolini lera no meu olhar meu grande amor pelo meu Brasil. Augurou-me os mais completos triunfos à mocidade do meu país. E concitando-me a não esmorecer no entusiasmo e na fé pelo futuro do Brasil, pediu-me que fizesse justiça à sua Itália". CARONE, E. Op. cit., p. 205. Em 18 de setembro de 1932, o embaixador italiano no Brasil, Vittorio Cerruti, envia o seguinte telegrama para a Chancelaria de Roma: "Tive anteontem um longo e cordial colóquio com João Alberto, que me fez declarações de estilo absolutamente fascista. Ele disse que o Brasil deverá permanecer um período de alguns anos de luta intestina se persistir no estilo liberal antiquado, a não ser que os brasileiros se convençam de que a salvação da nação na presente época histórica está nos regimes que exercitam uma autoridade indiscutível e ilimitada através da imposição de uma rígida disciplina.” PONTES, J. A. V. "Sangue brasileiro" In Nossa História, São Paulo: Vera Cruz, Ano 2, n² 21, julho 2005, p. 44.

${ }^{33}$ CARONE, E. Op. cit., p. 223.
} 
A luta do grupo de Mário Pedrosa pela unidade de toda a organização sindical revolucionária teve como decorrência inevitável a formação da Frente Única Antifascista em $1933 .{ }^{34}$ Em 5 de janeiro desse ano, o jornal A Platéia divulga o parecer esclarecedor de Pedrosa sobre o Congresso Anti-guerreiro realizado em Amsterdã, sob a responsabilidade de Henry Barbusse e Romain Rolland. Nele, Pedrosa questionava a eficácia de ação do Congresso de Amsterdã posto que seus membros não partilhavam de análises comuns sobre as causas motivadoras da guerra. No caso de Pedrosa, a guerra tinha sua raiz na luta imperialista entre as grandes potências e deveria ser combatida pelo proletariado internacional. Por sua vez, o Congresso constituía-se de um "amálgama heterogêneo de elementos vindos das diversas classes sociais que, por definição, não podiam misturar as bandeiras nem deliberar em comum” e Pedrosa continua "os seus iniciadores são dois escritores pequeno-burgueses que não passam de simples pacifistas humanitários. Barbusse, que é o presidente do Congresso, se caracteriza pelo confusionismo abjeto, incapaz de uma atitude política definida. (...) Os outros personagens do congresso ainda valem menos do ponto de vista revolucionário contra a guerra imperialista. Que se pode esperar de um Congresso anti-bélico que tem como principais figuras um Patel, ferrenho nacionalista burguês hindu (...) (ou) um general alemão Schonaich que, enquanto assina no congresso manifestos contra o pacifismo, escreve dias depois num jornal de Berlim um artigo declarando-se pacifista". 35

Ainda que houvesse as melhores intenções possíveis na organização do Congresso Anti-guerreiro por Barbusse e Rolland, Pedrosa acreditava que o pacifista de hoje poderia se tornar o nacionalista de amanhã e que a falta de uma consistência maior dos argumentos e dos objetivos do movimento político levaria à sua própria ruína. Sendo assim, era preciso denunciar os interesses e as ações da burguesia que levavam

\footnotetext{
${ }^{34}$ Carone relata: “A luta operária não se limita, porém, ao integralismo. A tradição antifascista é anterior ao movimento do Sigma e, na década de 1920, os protestos contra o regime mussoliniano são comuns. Depois de 1930 dá-se simples continuidade que aparece ilustrada em contínuas afirmações. Em janeiro de 1931, quando a nossa burguesia quer homenagear o aviador Ítalo Baldo, La Difesa, jornal antifascista de São Paulo, organiza contramanifestação que é proibida pela polícia. Em novembro de 1933, quando o nazismo controla toda a Alemanha, os intelectuais paulistas lançam Manifesto de denúncia contra a guerra e seus articuladores, o fascismo (...). O repúdio ao nazismo aparece com a colocação de bombas em cinemas onde se exibem fitas patrióticas alemãs ou quando os operários do Recife negam-se a amarrar o dirigível Hindemburg no seu mastro. Mas o que melhor fundamenta a luta é a idéia de se congregar permanentemente em forma de combate um 'Comitê Estudantil de Luta Contra a Guerra Imperialista e o Fascismo', cria-se depois o Comitê Nacional Provisório de Luta Contra a Guerra Imperialista e o Fascismo, filiado ao movimento Internacional nascido em Amsterdã-Player, por iniciativa de Henri Barbusse e Romain Rolland.” CARONE, E. Op.cit., pp. 127-128.

${ }^{35}$ CARONE, E. A segunda república (1930-1937). São Paulo: Difusão Européia do Livro, 1973, p. 392.
} 
países como a Alemanha, a Itália e o Japão a entrarem em guerra contra as demais potências econômicas e militares pela conquista de novos mercados no mundo. Somente a revolução internacional dos comunistas poria fim às guerras; diz Pedrosa: "Para os marxistas revolucionários, isto é, para os comunistas, só o proletariado organizado é capaz de lutar efetivamente contra a gue rra imperialista. Segundo os ensinamentos de Lênine só se pode lutar contra esta arrastando toda a massa proletária organizada a uma ação comum, sob a direção revolucionária da IC, como só há um meio de conduzir a luta contra ela: é a 'transformação da guerra imperialista em guerra civil'. (...) Nessa questão capital não só para a sorte do proletariado como de toda a humanidade, o comunista deve guardar intransigentemente a clareza dos princípios: a ação contra a guerra é, e tem de ser, uma questão de luta de classes."

Seguindo as proposições de Lênin em "O imperialismo, fase superior do capitalismo" (1917), Pedrosa dizia que se o capitalismo fosse conservado, a guerra não poderia ser evitada. Em contraposição à proposta dos socialistas para um movimento pacifista que unisse os mais diversos interesses de classe, Pedrosa apresentava as teses da esquerda comunista: “A fração comunista que está seguindo com mais fidelidade a política de Lênine, nessa questão, são os oposicionistas da esquerda, liderados por Trotski, que no Congresso de Amsterdã a sua ala esquerda, marxista-revolucionária, constituídos em minoria e que, à resolução vaga, feita para agradar a todos os paladares e a contentar a todas as opiniões adotada pela maioria da assembléia, opuseram uma resolução de nítido caráter proletário, com proposições claras, positivas, sem rodeios, comprometedoras, para uma ação eficaz e revolucionária contra as guerras imperialistas. Eles lançaram a idéia de um congresso imediato das grandes organizações proletárias existentes, com o objetivo de traçar um plano de mobilização das massas proletárias para lutar contra as ameaças da guerra que estão surgindo em toda a parte, especialmente contra a União Soviética." $" 37$

Não se propunha a ruptura com o Congresso Anti-guerreiro, mas a atuação nele para forçar mudanças em suas propostas. Aqui está o sentido inequívoco da frente única que atuaria mais tarde em São Paulo contra os integralistas: "Baseando-se nas declarações solenes feitas pela Segunda Internacional no seu congresso do ano passado, sobre a própria pressão das massas proletárias que a seguem, de solidariedade à URSS em caso de agressão imperialista (...), a IC devia tomar publicamente a iniciativa desse

\footnotetext{
${ }^{36}$ CARONE, E. Op. cit., p. 393.

${ }^{37}$ Idem, ibidem, p. 394.
} 
congresso, convidando para ele não só as duas Internacionais socialistas reformistas, (...) e outras organizações proletárias de massa existentes. Os reformistas estariam assim presos pela palavra pública que deram, pelos seus órgãos mais altos, e ficariam desmascarados perante a massa proletária que os segue, se recusassem o convite. No caso contrário, se aceitassem, esse congresso seria o único órgão possível, nas condições atuais, capaz de arrastar o proletariado em peso, numa luta decisiva, gigantesca contra as ameaças de guerra à URSS, contra o banditismo imperialista nas colônias e países dependentes (China, América do Sul etc.) contra os perigos de guerras inter-imperialistas em geral. As conseqüências dessa luta seriam incalculáveis, podendo levar a um resultado que à maioria poderia parecer paradoxal, mas que para o marxista seria 'normal'. É que em vez de acabar a guerra, o que acabaria seria o próprio regime capitalista." 38

Em 7 de outubro de 1934, os integralistas organizaram uma grande marcha do movimento em São Paulo. Os operários e as esquerdas reuniram-se para deter a manifestação integralista. ${ }^{39}$ Edgard Carone descreve assim o conflito: "Pela primeira vez o Sigma tenta fazer marcha espetacular na capital paulista e, para isto, são convocados adeptos de outros Estados. Enquanto as 'legiões' sobem a Avenida Brigadeiro Luís Antônio, para depois se concentrarem na Praça da Sé, as esquerdas ocupam os seus lugares e permanecem no Edifício Santa Helena; a polícia, no entanto, guarnece toda a Praça da Sé e adjacências. Às três horas da tarde 'começam a chegar os primeiros membros do Partido Integralista (...)'. Logo depois surgem os primeiros conflitos entre pequenos grupos populares e integralistas; nesta hora, por descuido da polícia, dispara uma metralhadora que provoca pânico e mortes. Logo a situação serena e começam a chegar 'as primeiras tropas integralistas (...)'. Quando já haviam chegado cerca de 500 homens, novamente irrompe tiroteio. Desta feita os primeiros disparos partiram dos altos do prédio Santa Helena e do lado oposto. (...) a ordem é estabelecida pela segunda vez. Novamente reunidos no centro da praça, desta vez em menor número, os integralistas faziam esvoaçar as suas bandeiras e davam os seus gritos característicos

\footnotetext{
${ }^{38}$ CARONE, E. Op. cit., p. 394.

39 Edgard Carone relata que dias antes da marcha integralista em São Paulo, o PCB lança um manifesto "ao Partido Socialista, ao Partido Trabalhista, à Liga Comunista Internacional, a todos sindicatos da Coligação Proletária, à Federação Operária de São Paulo, à Confederação do Trabalho e autônomos, a todas organizações populares anti-guerreiras, antifascistas, estudantis, etc" para a formação de uma gente única contra os integralistas. CARONE, E. A república nova (1930-1937). São Paulo: Difel, $2^{a}$ edição, 1976, p. 125.
} 
- Anauê! Anauê! (...) Novos tiros foram disparados (...). E o resultado final é a fuga espavorida dos integralistas." 40

Anos mais tarde, Mário Pedrosa expunha sua luta ao lado dos operários, anarquistas, comunistas e socialistas contra a marcha dos integralistas em São Paulo: "O nazismo vitorioso na Alemanha estimulou os fascistas caboclos a vestirem camisa verde, fazerem saudação de braço estendido, arranjarem um führer nacional, armaremse e saírem às ruas espancando homens de esquerda onde encontrassem, e desfilando com sua milícia militarizada de milhares de homens até cerimônia de juramento à bandeira no Largo da Sé, em face do edifício Santa Helena, onde tinha sede a Federação Brasileira dos Sindicatos dos Trabalhadores, recém-criada. O aparato militar e acintoso da cerimônia visava, conforme tática nazista da conquista da rua antes da tomada do poder, intimidar os trabalhadores ameaçando a própria existência de seus sindicatos de classe. Apesar de inexperiente ainda, a federação compreendeu o perigo e o sentido da manobra e da ameaça. Então, a seu apelo, uma frente única de todas as esquerdas se formou com o fito expresso de, em face da passiva neutralidade do governo, dispersar pela violência aquele desfile. A 7 de outubro de 1934, com efeito, o povo em massa dos bairros proletários acorreu ao Largo da Sé armado de qualquer coisa (pau, faca, foice, espingarda, pistola) e dissolveu no peito (centenas de feridos, uma dezena de mortos dum lado e do outro, muitíssimas prisões) a parada dos galinhas-verdes que nunca mais desfilaram pelas ruas de São Paulo. Continuaram a fazê-lo porém no Rio até o golpe estado-novista de novembro de 1937, com que, com sua cumplicidade, a ditadura liberal indefinida de 1930 se definiu como fascista, e o Sr. Felinto Muller (...) (instituiu) pela primeira vez o terror nazista em nossa terra., ${ }^{, 41}$

\footnotetext{
${ }^{40}$ Idem, ibidem, pp. 125-126.

41 Felinto Muller foi da ala pró-fascismo do governo Vargas. PEDROSA, M. "Entre a Semana e as Bienais" In Mundo, homem, arte em crise. (org. Aracy Amaral). São Paulo: Perspectiva, 1986, pp. 278279. Comenta Mary Houston: “(Em 1934, Mário) (...) tenta formar uma frente única das esquerdas contra o integralismo. No dia 7 de outubro, a esquerda consegue impedir uma passeata integralista no Largo da Sé em São Paulo, onde ocorre um grande tiroteio com mortos e feridos de ambos os lados e, inclusive, na própria polícia. (...) Num determinado momento em que a polícia havia conseguido dispersar os manifestantes, Mário se encontrou sozinho num canto da praça. Foi então cercado por vários integralistas que gritavam: "vamos acabar com esse podre". Por sorte uma menina de 12 anos, filha de Klassenkampt, membro do exército vermelho, colocou-se diante de Mário dizendo: "Não tenha medo, eu vim aqui para ajudar você." Diante disto, os integralistas o deixam em paz. Porém, pouco depois Mário seria baleado (...). Seus amigos o aconselham a precaver-se, pois seu nome é um dos primeiros numa lista de pessoas a serem mortas pelos integralistas. Mário refugia-se então na Galeria Itu, na Rua Barão de Itapetininga, onde ocorre a exposição modernista de Portinari." HOUSTON, M. "Cronologia” In Mário Pedrosa: arte, revolução, reflexão. Centro Cultural Banco do Brasil, Porto Alegre, 06-07-1992, pp. 54-56. Também, o professor Edmundo Moniz conta: "Eu conheci Mário Pedrosa em 1934, na sede do Sindicato dos Professores. Edifício Odeon (Rio de Janeiro), então sob a presidência de Rodolfo Coutinho. Eu era onze anos mais moço do que os dois. Rodolfo Coutinho e Mário Pedrosa militaram no Partido Comunista
} 


\section{$\underline{\text { O despertar da consciência política no meio artístico brasileiro }}$}

Com a Revolução de 1930, a pressão dos acontecimentos políticos e sociais se fez sentir de tal forma no ambiente artístico e cultural do Brasil que artistas, escritores e intelectuais começaram a participar mais ativamente da política. ${ }^{42}$ De fato, a acirrada disputa pelo poder, entre as oligarquias e o tenentismo, repercutiu na agitação criativa que ora tentou formular novo rumo para o país, ora buscou encontrar novas expressões artísticas mais condizentes com a circunstância vivida. Embora as preferências e as posições, adotadas pelos artistas, estivessem longe do amplo consenso, todos eles tencionaram encontrar uma solução definitiva para o lapso existente e corrosivo entre arte e sociedade. Com a necessidade de tomar posição frente aos problemas de seu tempo, os artistas modernos se afastaram das polêmicas eminentemente artísticas da década de vinte e substituíram-nas pela ascendência da temática social. A política passava a ter maior relevância do que a discussão centrada sobre a legitimidade de um estatuto próprio para as artes, ou como diria Mário Pedrosa, as polêmicas deixavam de ser artísticas para se tornarem políticas. ${ }^{43}$

No plano artístico, duas ações se destacaram no início dos anos trinta: a reforma da Escola Nacional de Belas-Artes, no Rio de Janeiro, e a fundação de associações para

\footnotetext{
Alemão, pertenceram à oposição de esquerda, colocando-se ao lado de Trotski na luta contra Stálin, e defendiam a formação da IV Internacional. Mário Pedrosa, que fundara em 1933, a Liga Comunista Internacionalista em São Paulo, andava de bengala como conseqüência de uma bala na coxa que o tinha atingido num conflito, na Praça da Sé, entre os integralistas e comunistas.” Idem, ibidem, p. 13.

42 Walter Zanini restitui à efervescência cultural da década de 1930 sua significação como elo fundamental entre as atividades da Semana de 1922 e o cenário artístico e cultural do Brasil no PósGuerra: "O processo de abertura cultural desencadeado nas décadas de 1910 e 1920 teria continuidade nos anos de 1930, sendo uma de suas evidências maiores a publicação de obras fundamentais sobre a sociedade brasileira, assinadas pelo modernista Sérgio Buarque de Holanda, pelo regionalista, 'modernista a seu modo', Gilberto Freire e Caio Prado Júnior. As restrições à liberdade de pensamento, impostas no período de 1937-45, prejudicaram, em certas áreas mais que em outras, esse desenvolvimento, mas não conseguiram sustá-lo. Na verdade, o poder não se furtava, às vezes, a assimilar, com oportunismo, os princípios do Modernismo." ZANINI, W. A arte no Brasil nas décadas de 1930-40 - o grupo Santa Helena. São Paulo: Nobel \& Editora da Universidade de São Paulo, 1991, pp. 22-23.

${ }^{43}$ Cf. PEDROSA, M. "Entre a Semana e as Bienais” In Mundo, homem, arte em crise. (org. Aracy Amaral). São Paulo: Perspectiva, 1986, p. 278. Paulo Mendes de Almeida, que viveu as transformações da época, disse: "Logo após a vitória da revolução de 1930, instalou-se no País generalizado estado de ebulição. Passados os primeiros momentos de euforia dos vencedores, e de desalento dos vencidos, entrou a Nação num período de sobressaltos, dela se apoderando uma sensação de instabilidade, com as modificações sucessivas dos quadros de governo, e a possibilidade sempre presente de novos pronunciamentos militares. Em São Paulo, sobretudo, vivemos dias de permanente inquietação, que em pouco nos conduziriam à trama das conspirações de que viria a irromper a Revolução Constitucionalista de 1932.” ALMEIDA, P. M. de. De Anita ao Museu. São Paulo: Perspectiva, 1976, p. 41.
} 
promoção da arte moderna, em São Paulo. Essas iniciativas colaborariam para o esforço de renovação da produção artística e consolidariam opções estéticas no Brasil até pelo menos o fim da década de 1940. Se a arte de viés social começava a ser difundida por todo o País, nem por isso seus adeptos ganharam aprovação imediata e unânime da sociedade. As dificuldades de legitimidade e de sobrevivência da arte moderna eram enormes: nessa época, a arte restringia-se a objeto de fruição da elite econômica e de intelectuais e por uma série de razões não conseguira ainda alcançar o grande público; os resultados da crise de 1929 desaconselhavam novos investimentos em arte a curto prazo; os velhos acadêmicos inimigos da arte moderna ganhavam novos aliados oriundos tanto das piores forças políticas que chegaram ao poder com a Revolução de 1930, como de simpatizantes da estética fascista. O antagonismo de conservadores e modernistas se exprimiu na luta entre aqueles que condenavam as manifestações mais renovadas da arte para salvar os valores da família e da pátria e aqueles que defendiam a arte moderna para a formação do homem futuro.

Em 1930, a Escola Nacional de Belas-Artes mantinha com vigor sua tradição acadêmica e funcionava com recursos governamentais - por isso o controle de suas atividades foi mais visível do que nas sociedades para promoção de arte moderna de São Paulo. Esses dois aspectos juntos fizeram com que a ENBA sustentasse por muito tempo convencionalismos artísticos e fosse enclave de uma mentalidade avessa às inovações modernas. A situação pareceu mudar quando os tenentes indicaram Francisco Campos para o ministério da Educação. Por sua vez, o chefe de gabinete do Ministério, Rodrigo Mello Franco de Andrade, foi responsável pela posse do jovem arquiteto Lúcio Costa, que entrara em contato com a arquitetura moderna e era admirador da Bauhaus e de Le Corbusier, como diretor da ENBA. Walter Zanini diz: "O diretor recém-nomeado empenhou-se em contratar novos professores, considerados pelos descontentes como 'futuristas' - Warchavchik, A. S. Buddeus, Celso Antônio e Leo Putz (...). Lúcio Costa, contudo, ao mesmo tempo que renovava, mantinha os velhos mestres, no que obedecia ao seu espírito de conciliação. No inevitável confronto de forças que se provocou, o antigo corpo docente acabaria por levar a melhor. ${ }^{, 44}$

Além das mudanças no curso de arquitetura da ENBA, a reformulação do Salão Nacional de Belas-Artes foi ponto alto da tentativa de Lúcio Costa para modernizar o meio artístico brasileiro. Segundo Zanini: "Lúcio Costa (...) tomaria naquele ano a

\footnotetext{
${ }^{44}$ ZANINI, W. História geral da arte no Brasil, (V. II). São Paulo: Instituto Walther Moreira Salles, 1983, pp. 569-570.
} 
decisão de transformar a XXXVIII Exposição Geral de Belas-Artes (1931) numa manifestação aberta a todas as tendências. O ‘Salão Revolucionário' ou dos 'Tenentes', como seria apelidado, constituiu-se por isso em novo marco da vanguarda. (Nas palavras de Mário Barata) 'Pela primeira vez a pintura moderna aparecia francamente ao grande público' (...) e no próprio reduto em que era intransigentemente rechaçada. Tudo, porém, duraria pouco. Diante da onda de protestos dos inconformados acadêmicos, o espírito conservador do certame foi restabelecido. (...) A pretendida reforma da ENBA, que se incorporava à Universidade, não resistiu mais que alguns meses. Como afirmou Manuel Bandeira: 'Não creio que a arte dos tenentes vingue na Escola. A retirada do ministro Campos arrastará provavelmente a saída de Lúcio Costa. Os generais voltarão ao trambolho da avenida Rio Branco. Não faz mal. Lúcio Costa deixa um ponto luminoso na história daquela casa: reformou em bases decentes o curso da arquitetura e deu o exemplo de uma verdadeira exposição de artes plásticas. ",45

A contribuição de Lúcio Costa foi abrir espaço para o ensino e para a divulgação das novíssimas tendências da arquitetura e da arte através da ENBA e seu erro foi tentar conciliar adeptos de arte acadêmica e moderna - prática que seria revalidada posteriormente pelos Salões Nacionais nos anos 1940 com a criação da Divisão Moderna - na mesma instituição. Entretanto, o Salão Revolucionário foi um retrato da variada produção artística brasileira, pois ali se congregaram modernistas da primeira geração e da nova geração, tais como Flávio de Carvalho e Candido Portinari, além de pintores acadêmicos e arquitetos. Para Zanini: "A reformulação do Salão Nacional, graças à liberalidade de espírito de Lúcio Costa, coadjuvado pelo poeta Manuel Bandeira, permitia finalmente que a ele tivessem acesso os artistas modernos. É verdade que este ensejo foi logo contrariado e que se reentrava a seguir no velho domínio do pompierismo. Mas o Salão Revolucionário provocava uma quebra nas legitimidades anteriores, mesmo sendo uma miscelânea paradoxal de pintores, escultores, gravadores e arquitetos, entre a índole mais retardatária e o que constituía as vanguardas locais."46

No caso de São Paulo, a falta de apoio governamental e a crise no incipiente mercado de arte levaram os artistas a se organizar em associações nos idos de trinta. Essas associações visavam criar espaços para a promoção da arte moderna. Em 23 e 24 de novembro de 1932, surgem respectivamente a Sociedade Pró-Arte Moderna (SPAM)

\footnotetext{
${ }^{45}$ ZANINI, W. Op. cit., pp. 569-570. (parênteses nossos).

46 ZANINI, W. A arte no Brasil nas décadas de 1930-40 - O grupo Santa Helena. São Paulo: Nobel \& Editora da Universidade de São Paulo, 1991, p. 26.
} 
e o Clube dos Artistas Modernos (CAM). Essas associações cumpriram seus objetivos imediatos de oferecer oportunidade de trabalho para os artistas e de difundir a arte moderna para um público que a desconhecia quase completamente. Porém elas serviram também como instâncias para o aprofundamento de outras questões mais urgentes. Com mais projeção do que as poucas associações não institucionais de artistas, existentes no Rio de Janeiro, as de São Paulo contribuíram para a continuidade das pesquisas modernas em arte e mais ainda para a fomentação de debates sobre temas emergentes da sociedade brasileira - nesse aspecto, o CAM teve muito mais importância do que a SPAM. Se antes o vínculo entre arte e circunstância social parecia frouxo, a partir do surgimento das associações de artistas para promoção da arte moderna completoutse o irremediável esforço de pensar os problemas da arte em sua conexão com os acontecimentos sociais e políticos que ocorriam no Brasil e no mundo.

A debilidade da academia e o fato de as grandes produções artísticas dependerem com exclusividade de iniciativas particulares tornaram possível maior liberdade de expressão, inclusive política, para os artistas de São Paulo. Dessa forma, a luta que primeiro foi direcionada ali contra as forças da reação no campo artístico em 1922 encontrou na política seu último campo de batalha em 1930. Mário Pedrosa comenta: "As idéias políticas revolucionárias vieram à tona com a crise das instituições e a crise econômica do café que deram por um momento, sobretudo em São Paulo, ligeiros sintomas de vacância de poder. Osvaldo de Andrade, numa profissão de fé comunista, rompeu com a própria classe, a aristocracia do café, vencida e decadente, convertido por um momento à ideologia do Partido Comunista de então e à revolução proletária. Ao lado e em oposição à Sociedade Paulista de Arte Moderna, fundada por antigos promotores da Semana, já agora acusados de grã-finos, aristocratas e reacionários, lança-se o Clube de Arte Moderna, Flávio de Carvalho, seu organizador e animador, intelectual de alta têmpera, artista de múltiplas possibilidades, rico e desabusado (...) enche o meio paulistano com os ecos de suas atividades e seus desafios. (...) $\mathrm{O}$ ambiente de alta tensão social e de crise institucional não permitia mais as explosões puramente estéticas ou culturais da Semana." ${ }^{, 47}$

A Sociedade Pró-Arte Moderna foi resultado do esforço conjunto de interessados em arte e de artistas, ligados à geração da Semana de 1922, para retomar as atividades culturais e produzir arte moderna no tempo em que a crise política e

\footnotetext{
${ }^{47}$ PEDROSA, M. "Entre a Semana e as Bienais” In Mundo, homem, arte em crise. (org. Aracy Amaral). São Paulo: Editora Perspectiva, 1986, pp. 277-278.
} 
institucional assolava o Estado de São Paulo. A reunião de inauguração da SPAM ocorreu na Casa de Gregori Warchavchik, no dia 23 de novembro de 1932, e dela participaram Paulo Mendes de Almeida, Paulo Prado, Olívia Guedes Penteado, Anita Malfatti, Tarsila do Amaral, Lasar Segall, entre outros. Enquanto o último tornou-se responsável pela organização e execução dos projetos da SPAM, Tarsila do Amaral logo se desligou da associação e participou depois mais ativamente no CAM. Nos mais variados campos da cultura, a SPAM visava atuar. Como diria Paulo Mendes de Almeida: "O programa da SPAM era vasto. Propunha-se a 'estreitar as relações entre os artistas e as pessoas que se interessam pela arte em todas as suas manifestações', promover exposições, concertos, conferências, reuniões literárias, organizar anualmente o 'mês da arte', e instalar uma sede social, 'com salões de festas e exposições, uma sala de leitura, ateliê para artistas, etc.', reclamando para tanto, 'a colaboração de todos os artistas e amigos da arte'. E a verdade manda dizer que, embora, com duração efêmera, quase tudo isso conseguiu ela fazer." 48

Por serem os sócios da SPAM, em sua maioria, gente da alta sociedade ou artistas e intelectuais já reconhecidos no meio artístico paulista, não houve entre eles o interesse direto, como no CAM, pelos temas políticos. Tudo se resolvia à sombra das manifestações artísticas modernas, que naquele contexto bastavam para causar grande celeuma e reações indignadas por parte de moralistas, da imprensa conservadora e sobretudo dos integralistas. Em seu breve período de existência, a Sociedade produziu duas exposições: a primeira, em 28 de abril de 1933, trazia peças das coleções particulares de Olívia Guedes Penteado, Samuel Ribeiro, Paulo Prado, Mário de Andrade e Tarsila do Amaral. Nela se podia ver Picasso, Léger, Brancusi, Lipchitz, De Chirico, Le Corbusier, entre outros artistas importantes e também nomes de peso da cena paulista, tais como: Anita Malfatti, Victor Brecheret, Lasar Segall, Antonio Gomide, Hugo Adami, Tarsila do Amaral. A segunda exposição ocorreu no final de 1933 e dela participaram artistas residentes no Rio de Janeiro, entre eles: Guignard, Di Cavalcanti e Portinari. Essas exposições causaram menos contenda entre setores conservadores e a SPAM - mesmo assim Paulo Mendes de Almeida registra um atentado contra a $\mathrm{I}^{\mathrm{a}}$ exposição de arte moderna da SPAM - do que seus bailes vanguardistas $^{49}$ e o fato de Lasar Segall encabeçar a comissão executiva da Sociedade.

\footnotetext{
48 ALMEIDA, P. M. de. De Anita ao Museu. São Paulo: Editora Perspectiva, 1976, p. 42.

${ }^{49}$ Os bailes da SPAM foram organizados com a única finalidade de arrecadar fundos para a associação, mas se tornaram um dos grandes eventos da cena paulista. Neles se via o trabalho coletivo de artistas na
} 
Os bailes da SPAM foram os alvos de crítica escolhidos tanto pela polícia do Governo Provisório como pelos setores conservadores da sociedade civil. No primeiro baile da SPAM em 1933 ocorreu a intervenção da polícia sem conseqüências mais graves. Muitas pessoas ali reunidas quiseram manifestar, em tom festivo, sua opinião sobre a Revolução Constitucionalista com uma marchinha de crítica ao Governo Provisório. Porém, relata Paulo Mendes de Almeida: "a tropa que policiava as imediações, e que era tropa da ditadura vitoriosa, não gostou dessa versão. E o baile acabou, para não acabar pior, com os convidados saindo entre alas de baionetas..." ${ }^{50}$ Já o segundo baile, realizado no início de 1934, provocou reações indignadas dos setores conservadores, não tanto pelas quebras de decoro cometidas por um ou outro convidado em tempos de Carnaval, mas pelo simbolismo iconoclasta que revestia a SPAM como associação de artistas modernos contra os valores da religião, do civismo e dos bons costumes. Por isso, o integralista José Bonifácio de Souza Amaral, que já condenara publicamente o Teatro da Experiência de Flávio Carvalho no CAM, escreveu um artigo na Secção Livre do Diário Popular denunciando as atividades subversivas dos membros da SPAM.

Diz Paulo Mendes de Almeida: “(Em 21 de fevereiro de 1934), José Bonifácio publicou uma tremenda objurgatória contra a Sociedade, a que deu o título de 'Os fins secretos da Spamolândia'. Insultos não escassearam nesse artigo, inspirado, segundo seu autor, em sua crença em Deus, na Pátria, na Família e na suprema força da Moral Cristã. Para ele, a SPAM era um conglomerado de 'estrangeiros de nacionalidade um pouco incerta, outros neo-brasileiros desafetos de nossas tradições, e outros ainda, embora pertencentes ao tronco racial mais antigo' - todos empenhados num programa de dissolução dos costumes. E terminava com um apelo às autoridades: 'No meu entender, a polícia de São Paulo devia fechar a SPAM com mais razões do que teve para fechar o Teatro da Experiência.' (...) Naquele arrazoado havia, evidentemente, injustiça e paixão.

\footnotetext{
decoração do salão de festas, a apresentação de composições de Camargo Guarnieri e os balés de Chinita Ulmann. Paulo Mendes de Almeida diz: "seus organizadores se obstinaram em dar-lhe (ao baile "Carnaval na Cidade de SPAM" em fevereiro de 1933) o cunho de uma realização artística. E sob esse aspecto, efetivamente, conseguiram fazer alguma coisa que jamais fora vista em São Paulo. Sem forçar a expressão, de um baile de Carnaval conseguiu-se fazer verdadeira obra de arte.” ALMEIDA, P. M. de. Op. cit., p. 45. (parênteses nossos). Com o dinheiro arrecadado no evento é que se pode estruturar a associação de artistas e construir sua nova sede no palacete Campinas ao lado da Praça da República. Como os gastos com a nova sede da SPAM tinham exaurido os recursos financeiros da associação, organizou-se novo baile de carnaval. À maneira das inovações artísticas do primeiro, o segundo baile foi denominado "Expedição às matas virgens da Spamolândia".

${ }^{50}$ Idem, ibidem, p. 46.
} 
A resposta que se deu foi o silêncio." ${ }^{, 51}$ Iniciava-se a campanha contra a SPAM. Embora não tenha recebido o mesmo tratamento dado ao CAM, que foi fechado à força pela polícia sob a acusação de difundir idéias subversivas, a SPAM teve também seu destino selado pela intolerância do meio social paulista e pelas disputas políticas que se abriam no contexto histórico e social do Brasil e do mundo.

A saída de Lasar Segall da Comissão Executiva da Sociedade e a morte de Olívia Guedes Penteado, em 1934, assinalam o fim das atividades da SPAM. Sem unanimidade, Segall manteve-se à frente da comissão executiva e ficou enfraquecido com a morte de Olívia Guedes. Depois de proferir a conferência "Das relações entre a arte gótica e a arte moderna", Segall foi destratado pelo público ouvinte e por um grupo de sócios descontentes com as diretrizes da SPAM. Diante das acusações contra sua pessoa e contra o expressionismo, Segall resolveu deixar a Sociedade. Em carta aos membros da comissão executiva, ele explicava: "Já por alguns meses estava eu ciente dos ataques injustificados e injustificáveis de alguns colegas sócios da Spam, os quais tomavam por ensejo cada realização da sociedade, assim como todas as minhas palavras e todos os meus atos, para fomentar, atrás de minhas costas, intrigas mesquinhas e no mínimo desagradáveis contra minha pessoa. (...) As insinuações, porém, do mesmo grupo de 'descontentes', após a (Conferência), (...) ultrapassaram por demais o limite do que é permitido no domínio da crítica legítima. (...) Considero-as intoleráveis do ponto de vista humano e artístico, e só posso qualificar de baixa e covarde",52

A sorte estava lançada e a SPAM não teve tempo de se defender: após a saída de Lasar Segall, os membros da comissão executiva fizeram uma reunião derradeira para decretar o fim da Sociedade. Da mesma forma que o CAM, a perseguição sistemática feita pelos aparelhos do governo e pelos integralistas contra as associações de artistas em São Paulo levou os sócios da SPAM a se dispersarem e, por conseguinte, a arte moderna encontrou-se mais uma vez desamparada e na berlinda dos acontecimentos políticos. Apesar da retórica de José Bonifácio de Souza Amaral, o CAM foi sem dúvida mais atacado pelos poderes instituídos e pelas forças reacionárias do que a SPAM. Isso explica a sobrevida maior da SPAM. Ela era formada ou por gente reconhecida no que fazia, ou por membros da alta sociedade sem motivação para lutar por transformações sociais profundas que representassem perigo evidente para sua

\footnotetext{
${ }^{51}$ Idem, ibidem, p. 59.

${ }^{52}$ Carta de Lasar Segall aos membros da Comissão Executiva da SPAM. Reproduzida em ALMEIDA, P. M. de. Op. cit., p. 73. (parênteses nossos).
} 
própria classe, ao passo que o CAM levou até as últimas conseqüências as idéias modernas de transformação estética e política da sociedade para a formação do homem do futuro. Se as duas associações estavam unidas pela intenção comum de promover a arte moderna num meio inóspito às novidades, o CAM nasceria como dissidência e tentativa de ultrapassar os limites da SPAM. ${ }^{53}$

Na expressão de Paulo Mendes de Almeida, o CAM foi uma dissidência da SPAM "antes que a SPAM existisse"; por isso ele nasceu apenas um dia depois da inauguração dela. O CAM foi fundado por Flávio de Carvalho com a ajuda de Antônio Gomide, Carlos Prado e Di Cavalcanti em um prédio da Rua Pedro Lessa, número 2, próximo ao Viaduto do Chá, região central de São Paulo no final do ano de 1932. Os quatro fundadores decidiram pintar a sede do Clube, “cada um, um painel nas paredes. Houve festa com vinho e barulhada, a festa se espalhava pelas janelas a fora e alcançava o passante logo em baixo; Nair Duarte Nunes trouxe um gigantesco bolo que apareceu entre cânticos e gritos estranhos, Noêmia Mourão (então aluna de Di Cavalcanti) foi enviada ao filósofo italiano, dono do restaurante do lado (...) para a compra de garrafões de vinho. Os painéis se prolongaram por uma semana, entre visitas, discussões, danças ao som do pente com papel de seda e cantos esquisitos. (...) Frank Smith e senhora ofereceram um vodka com pimenta curtido em rapé. Logo apareceu um piano não sei donde e com ele, executores. Mais gente veio, Anita Malfatti, Osvaldo Sampaio, etc... e o Clube dos Artistas Modernos, solidamente fundado, progredia com rapidez."

\footnotetext{
${ }^{53}$ Paulo Mendes diz que Flávio de Carvalho foi o responsável pela idéia de fundar uma associação de artistas em São Paulo: “(...) numa conversa, no salão de chá do antigo Mappin Stores, à Praça do Patriarca. (...) Achavam-se presentes Arnaldo Barbosa, Vitório Gobbis, o autor destas linhas e Flávio de Carvalho, que foi o pai da idéia e que ali a expôs a seus companheiros. Depois combinaram-se encontros para falar sobre o assunto com outras pessoas.” ALMEIDA, P. M. de. Op. cit., p. 76. Para Toledo, Flávio de Carvalho pensou em fundar uma associação de artistas com vistas a suprir a carência de espaços de exposição de arte moderna: "Terminado o Carnaval de 1932, vem a São Paulo (...) o pintor japonês (...) Tsuguharu Foujita (...) que procurava um lugar para expor em São Paulo, e Geraldo Ferraz acaba por apresentá-lo a Flávio de Carvalho que poderia resolver o impasse, o que aliás não aconteceu. (...) Esse fato (levou Flávio) a pensar com seriedade no seu próprio caso como artista militante e na escandalosa precariedade exibida por uma São Paulo tão carente de espaços para realizações artísticas, em particular as de tendência modernista. As antigas idéias de criar um "laboratório artístico" juntam-se agora a planos para a fundação de um clube...” TOLEDO, J. Flávio de Carvalho - O comedor de emoções. São Paulo: Brasiliense \& Editora da Universidade Estadual de Campinas, 1994, p. 124. (parênteses nossos). Ainda que isso fosse motivo decisivo, a fundação do Clube de Flávio de Carvalho tinha objetivos mais amplos e, por isso, houve a dissidência entre o CAM e a SPAM: "(os encontros para fundação da associação) foram numerosos, preliminares foram suscitadas, surgiram divergências, ora de forma, ora de substância. E Flávio (...) achou mais prático fundar desde logo o Clube dos Artistas Modernos, já que lhe pareciam morosas as démarches em curso para a criação da SPAM, e principalmente porque suspeitava de que esta acabasse por revestir um caráter um tanto ou quanto grã-fino - o que não era de todo improcedente." ALMEIDA, P. M. de. Op. cit., p. 76. (parênteses nossos).

${ }^{54}$ CARVALHO, Flávio de. "Recordação do Clube dos Artistas Modernos" In RASM (Revista Anual do Salão de Maio), n 1, São Paulo, 1939, s/ p. Apud TOLEDO, J. Op. cit., p. 1130. (parênteses nossos).
} 
Do início ao fim de sua curta existência, o CAM elaborou e executou propostas ousadas. Nele, muitos eventos se destacaram e causaram alarido nos diversos setores conservadores da sociedade: exposições de arte, concertos e recitais de música popular, conferências sobre assuntos artísticos e políticos, encenações teatrais. O objetivo principal do Clube, como centro irradiador de cultura, foi veicular a produção artística moderna e propor debates sobre temas atuais no meio social e artístico da cidade de São Paulo. Em pouco tempo, o CAM ganhou fama nacional. Paulo Mendes recordaria: "Em pouco tempo, o CAM tornourse um ponto obrigatório de encontro para quantos, na cidade, achavam-se de qualquer forma ligados às manifestações artísticas e intelectuais. Mesmo da Capital e de outros centros do País, surgiam pessoas diretamente endereçadas àquele prédio da Rua Pedro Lessa, àquele ambiente agradável, onde a conversa e as discussões ferviam, à medida que os copos se esvaziavam. (...) Muitas vezes se improvisaram festas, danças que entravam ruidosas pela madrugada adentro. Enfim, uma invulgar instituição, que ao extinguir-se, (...) deixou-nos a todos, não apenas saudosos, mas um pouco dispersos e desarvorados." 55

Se o clima de incertezas dominou o ano de 1932, por sua vez, o ano seguinte foi marcado pela tomada de consciênc ia política de grande parte dos artistas modernos. Por extensão, as associações de artistas tentaram se mobilizar, mas entre a SPAM e o CAM, apenas o último atendeu ao chamamento do momento vivido. ${ }^{56}$ No recém-fundado Clube de Artistas Modernos, a programação cultural foi intensa e contou com a contribuição de muitos artistas e intelectuais. Uma quantidade enorme de eventos foi produzida nos mais variados campos da arte e do pensamento, tais como: a apresentação da cantora Elsie Houston Péret e de composições de Marcelo Tupinambá; os concertos do violinista Frank Smith com Camargo Guarnieri ao piano; o quarteto Klein; os

\footnotetext{
55 ALMEIDA, P. M. de. Op. cit., p. 78. (parênteses nossos). Para Walter Zanini, o CAM notabilizou-se por seu programa muito mais ativo do que o da SPAM. Além disso, o Clube foi crítico do grã-finismo da SPAM: "detestamos elites - não temos sócios doadores". ZANINI, W. História geral da arte no Brasil, (V. II). São Paulo: Instituto Walther Moreira Salles, 1983, p. 583. Ainda que o CAM se jactasse de seu caráter independente, ele também dependeu de patrocinadores. Para um estudo mais detalhado sobre a repercussão da criação do CAM e sobre a polêmica entre o Clube e a alta sociedade paulista, ver: TOLEDO, J. Op. cit., p. 130 e seguintes.

56 Aracy Amaral comenta a iniciativa de Mário de Andrade de tentar introduzir a discussão de temas políticos e sociais na SPAM: “Até Mário de Andrade, nesse ano, reivindica posição nesse sentido, em texto no catálogo da exposição da SPAM, associação que congregava antigos modernistas: (palavras de Mário) '(...) O que realmente faz falta em nossa pintura spamista são criadores de ordem social. É uma falha sensível essa ausência de arte social entre nós, a não ser que compreendamos como tal o diletantismo estético, caracterizadamente burguês, em que persistimos. Esperemos que, em exposições futuras, o ecletismo natural da SPAM apareça completado com pintores que se resolvam a tomar posição qualificada, não apenas diante da natureza, mas da vida também."” AMARAL, A. Arte para quê?: a preocupação social na arte brasileira, 1930-1970: subsídios para uma história social da arte no Brasil. São Paulo: Studio Nobel, 2003, p. 41. (parênteses nossos).
} 
espetáculos de dança regional com Catita Passano e de dança moderna; um curso de pintura cubista ministrado aos sábados por Antônio Gomide; a exposição de "Arte dos loucos e das crianças", organizada por Osório César; a exposição da artista alemã Käthe Kollwitz e a de cartazes russos; uma série de conferências como a de Caio Prado Júnior sobre a URSS e a de David Alfaro Siqueiros sobre o muralismo mexicano; as encenações do Teatro da Experiência, criado por Flávio de Carvalho 57 .

O Teatro da Experiência foi alocado no antigo armazém de couros que se localizava no térreo do Prédio ocupado pelo CAM. A idéia era produzir teatro moderno em São Paulo e a empreitada foi bem-sucedida. No final de 1933, Flávio de Carvalho convidou Oswald de Andrade para escrever o primeiro texto a ser encenado na inauguração do teatro. A peça "O homem e o cavalo" não ficou pronta a tempo e, em novembro, estreou no Teatro da Experiência uma peça escrita pelo próprio Flávio de Carvalho. Relata Paulo Mendes de Almeida: "Era um armazém de proporções mesquinhas, onde se construiu um palco cênico e se alinharam cadeiras (...). Ali foi encenado o Bailado do deus morto - estranha peça 'falada, cantada e dançada; os atores usavam máscaras de alumínio e camisolas brancas, o efeito cênico era um movimento de luzes sobre o pano branco e o alumínio' - na palavra do próprio autor, que assim a descreve: 'A peça envolve uma escala de alguns milhões de anos e mostra as emoções dos homens para com seu próprio deus (...)'. Os principais atores eram o pintor Hugo Adami, Carmen Melo, os sambistas Risoleta e Henricão, Guilhermina Gainor e Dirce de Lima. Na direção estava o próprio Flávio de Carvalho. (...) sem dúvida constituía (...) uma importante experiência.",58

Malgrado o sucesso do espetáculo - que lotou a sala improvisada com duzentos e setenta e cinco lugares e que teve grande repercussão nos jornais de São Paulo e do Rio de Janeiro -, a Liga das Senhoras Católicas, o crítico Duarte Leopoldo e Silva e outros exigiram providências das autoridades contra o Teatro da Experiência. ${ }^{59}$ Condenando a peça de Flávio de Carvalho, Francisco de Sá escreveria o artigo "O ‘Teatro da Experiência' é um caso de polícia” no jornal A Platéia em 16-11-1933. Diz ele: "Antes de mais nada, devo dizer que o 'Teatro da Experiência', que ontem se inaugurou [nos] (baixos da sede do clube referido) é um caso de polícia. [...] Foi esta a impressão que tive, assistindo àquilo a que denominaram 'O Bailado do Deus Morto' e

\footnotetext{
${ }^{57}$ Para uma descrição completa da agenda do CAM, ver: TOLEDO, J. Op. cit., pp. 138-193.

${ }^{58}$ ALMEIDA, P. M. de. Op. cit., p. 82. (parênteses nossos).

${ }^{59}$ Cf. TOLEDO, J. Op. cit., p. 184.
} 
que outra coisa não é senão uma autêntica 'macumba', apenas com a agravante de que não tem o menor respeito pela religião, pela família ou pela moral! [...] Aquilo poderá ser muito interessante... para os 'artistas modernos'; [...] porém, o que não resta dúvida, é que se atenta contra a moral [...]. A censura proibia até as companhias rotuladas de 'gênero livre' [...]. Entretanto o departamento que agora superintende esse serviço [Delegacia de Costumes] admite que se profiram palavras obscenas [...]. O certo, porém, é que não se pode admitir numa Capital como a nossa, representações da natureza dessa que ontem, a título de Experiência, foi dada no teatro do 'Clube dos Artistas Modernos'., 60 .

Quando se preparava a terceira encenação do "Bailado do deus morto", a Delegacia dos Costumes mobilizou seus homens para controlar a situação no CAM. Toledo descreve o episódio: "seis emissários fardados, armados com espantosas metralhadoras e em ruidosas motocicletas, com ordem expressa de proibir a apresentação da terceira récita do teatrinho que, àquela hora, já estava repleto. Depois de um pequeno alvoroço na porta, enquanto Flávio discutia todo diplomático com os guardas, o intrépido e desassombrado tenente (João) Cabanas, interrompe abruptamente as negociações e explicações do artista e, dirigindo-se com arrogância aos policiais, lhes diz marcial e ameaçador: (...) “ - Digam ao Sr. Costa Netto que o teatro vai funcionar e se a polícia aparecer aqui, será recebida a bala! (...) Os uniformes se eletrizam indignados... (...) Afrontados e humilhados, os guardas (...) (chefiados) pelo próprio delegado Costa Netto que desrespeitado em sua determinação, se vê na obrigação moral de tomar satisfações pessoais (e) verificar com rigor as tais 'obscenidades' ali ocorridas" $"$.

A intervenção foi episódica, porém o Teatro da Experiência não escaparia de uma segunda investida da Delegacia dos Costumes. Alguns dias depois, mediante o fechamento quase iminente do teatro do CAM, Flávio de Carvalho fez publicar um abaixo-assinado no Diário de São Paulo que contou com as assinaturas de Mário Pedrosa, de Geraldo Ferraz, de Caio Prado Júnior, e de muitos outros. A iniciativa não

\footnotetext{
${ }^{60}$ TOLEDO, J. Op. cit., p. 184. [colchetes nossos].

${ }^{61}$ Continua Toledo: "Cabanas, que havia sido, afinal, o autor responsável pelo desenlace, misteriosamente desaparecera na multidão... (...) (apesar da tentativa de Flávio para contornar a situação, policiais e) a truculenta autoridade invade $(\mathrm{m})$ abruptamente o teatro, causando súbito pânico na platéia, para ali, diante da perplexidade geral, manter acirrada discussão com o artista, que agora, irritado, (...) vociferava furioso: 'A Constituição que vai ser votada e as demais leis em vigor nos garantem a liberdade de pensar, escrever e representar o que bem entendermos! (...) Se a polícia quer defender o decoro de parte da população, proibindo a representação da inocente peça, atentará contra os direitos da outra parte, dos que assistiram e aplaudiram o Teatro da Experiência"” Idem, ibidem, p. 195. (parênteses nossos).
} 
debelou o atentado contra o "teatrinho" que teve de fechar suas portas e, logo depois, também o CAM deixaria de existir.

$\underline{\text { Um divisor de águas na crítica brasileira: a conferência sobre Käthe Kollwitz }}$

Por um lado vanguardeiro e por outro militante, o CAM representou diferença de atitude frente à arte moderna. Sob pressão, ele foi uma tentativa sincera de inserir as discussões estéticas e as novas propostas artísticas nos debates sobre a complexidade dos acontecimentos sociais e políticos de sua época. Foi a partir dessa tentativa sem precedentes que se iniciaram, no Brasil, as primeiras veiculações de arte moderna e afim com temática acentuadamente social. Entre elas é preciso destacar a grande repercussão ocasionada pela exposição de Käthe Kollwitz - amiga de Rosa Luxemburgo - no CAM, com oitenta obras em várias técnicas como: xilogravuras, litografias, águas fortes e desenhos. Inaugurada em 2 de junho de 1933, essa exposição entusiasmou o meio artístico e intelectual. Daí, a crítica de Mário de Andrade, intitulada "Käthe Kollwitz” e publicada no Diário de São Paulo em 9 de junho, que diz ser a exposição da artista alemã uma das contribuições mais felizes do CAM, a conferência de Mário Pedrosa sobre "As tendências sociais de Käthe Kollwitz", em 16 de junho, e também os comentários de Afonso Schmidt: "Essa pintora, cujo talento orientou o período que acaba de encerrar-se na Alemanha, foi afastada da escola oficial de arte que dirigia, reintegrando-se na massa escura dos humildes, cujos sentimentos foram o motivo único de sua grande obra."62

Nessa época, as manifestações da arte de vanguarda alemã e afim se destacaram no gosto dos artistas brasileiros e em especial dos gravadores que, segundo Otília Arantes, já tinham visto: "Três anos antes, (a artista) Käthe Kollwitz (que) participara de uma mostra de gravura expressionista alemã, responsável pelo menos em parte, por

${ }^{62}$ Afonso Schmidt continua: "Diante da situação aflitiva dessa pintora inconfundível, algumas associações européias resolveram distribuir pelo mundo numerosos trabalhos, para que as associações de outros países se encarregassem de organizar exposições e vendê-los. (...) São Paulo conta neste momento cerca de oitenta gravuras de Käthe Kollwitz. São oitenta gritos de angústia. (...) a vida em estilhaços. Ontem presente à inauguração desse mostruário sombrio, onde só o gênio brilha, não pude deixar de pensar, por comparação, na felicidade "standard" de vida brasileira, que se esqueceu do calendário, que ainda não tomou conhecimento do ano apocalíptico de 1933..." SCHMIDT, A. "A vida", O Estado de São Paulo, 03-06-1933 Apud TOLEDO, J. Flávio de Carvalho - O comedor de emoções. São Paulo: Brasiliense \& Editora da Universidade Estadual de Campinas, 1994, p. 145. (parênteses nossos). Muitos artistas e intelectuais compraram obras de Käthe Kollwitz: Mário de Andrade, Tarsila do Amaral, Geraldo Ferraz, etc. 
um curioso fenômeno local de retorno de um impulso estético reprimido: o expressionismo, (...) justamente marcara o início de nossa revolução nas artes plásticas. Depois de um período recalcado pela preponderância das vanguardas francesas mais explosivas, estava novamente na ordem do dia, só que agora em chave social mais acentuada." ${ }^{63}$ Um exemplo dessa nova gravura brasileira de traço expressionista foi Lívio Abramo. Anita Malfatti e Lasar Segall introduziram o expressionismo no Brasil, em seguida, despontava Osvaldo Goeldi. Até mesmo nas obras de Cândido Portinari do final dos anos trinta, que prenunciaram sua adesão ao muralismo, há o traço expressionista sutil, acentuando no desenho o tamanho exagerado das mãos e dos pés das figuras humanas. Entretanto, como mostraria Mário Pedrosa em sua conferência, a artista alemã Käthe Kollwitz que fizera sua opção pelo retrato social, utilizaria principalmente o traço naturalista para acentuar as mazelas e a fisionomia de mães pobres que perderam seus filhos na guerra, de operários carcomidos, etc.

A célebre conferência de Mário Pedrosa sobre "As tendências sociais de Käthe Kollwitz" ocorreu numa sexta-feira, dia 16 de junho de 1933, às nove horas da noite no Clube dos Artistas Modernos. Devido ao seu sucesso, ela foi publicada em várias partes no semanário antifascista $O$ Homem Livre - dirigido por Pedrosa e por Geraldo Ferraz em 2, 8, 14 e 17 de julho de $1933 .{ }^{64}$ Seguindo de perto as considerações do crítico e ensaísta Sérgio Milliet, nos anos cinqüenta, sobre a importância da conferência de Pedrosa como inauguradora de uma crítica de arte brasileira de fundo sociológico, Aracy Amaral conclui que: “Até a publicação desse texto de Pedrosa, (...) a crítica de arte no Brasil se caracterizava por seu cunho descritivo, ou por uma retórica rançosa, ou era constituída de blagues afrancesadas, ou ainda vinculada ao colunismo social e à literatura, sendo em geral exercida por jornalistas, poetas e escritores, sem maior preocupação com a interpretação do fenômeno artístico. Redigido por ocasião da exposição de Käthe Kollwitz, em São Paulo, no Clube dos Artistas Modernos de Flávio de Carvalho, a esse artigo seguia-se pouco depois o texto inspirado na exposição de Portinari, (...). Mencionando já a visível preocupação social do pintor de Brodowski, Mário Pedrosa abre, com essas reflexões, um novo tempo na crítica de arte no País." ${ }^{, 65}$

\footnotetext{
63 ARANTES, O. B. Fiori. Mário Pedrosa: itinerário crítico. São Paulo: Cosac Naify, 2004, p. 33. (parênteses nossos).

${ }^{64}$ Em O Homem Livre, a conferência de Pedrosa saiu publicada com o subtítulo: "Käthe Kollwitz e seu modo vermelho de perceber a vida".

${ }^{65}$ AMARAL, A. Arte para quê?: a preocupação social na arte brasileira, 1930-1970: subsídios para uma história social da arte no Brasil. São Paulo: Studio Nobel, 2003, p. 38. (parênteses nossos).
} 
De modo geral, as conclusões de Aracy Amaral sobre a precariedade dos estudos estéticos e históricos de artes plásticas no Brasil do início dos anos trinta e sobre a importância do ensaio de Mário Pedrosa sobre Käthe Kollwitz são endossadas por Walter Zanini. Ambos entendem que o primeiro ensaio de fôlego de Pedrosa inaugurou um novo patamar mais alto de análise para a crítica de arte brasileira. Expõe Zanini: "A crítica de arte do Modernismo, bastante incipiente nos anos anteriores à década de 1930 e restrita a poucos nomes, emersos da literatura e do jornalismo, adquiriu maior consistência nos dois decênios seguintes. Alguns autores demonstravam melhor preparo e profundidade de conceitos, no crescente número dos que a exerciam, geralmente procedentes daquelas mesmas fontes culturais. $\mathrm{O}$ que equivale a dizer que perseverava sua condição autodidata. (...) (Os críticos mais conhecidos da década de 1930 eram:) Mário de Andrade, (...) Aníbal Machado, Luís Martins, Geraldo Ferraz, Paulo Mendes de Almeida e Sérgio Milliet. (...) (Contudo) desde 1933 destacava-se Mário Pedrosa, durante algum tempo radicado em São Paulo, depois de sua estada na Alemanha.,

A mesma pressão dos acontecimentos sociais e políticos que favoreceu a difusão e a publicação de autores marxistas, como alternativa para a crise que se vivia no País, foi responsável por despertar nos artistas e escritores o interesse pelas concepções de realismo artístico e pelo debate sobre a função social da arte. Por isso, o sucesso da conferência sobre Käthe Kollwitz deve ser avaliado como resultado da união do interesse que a obra da artista alemã despertava com o fato de a interpretação feita por Pedrosa basear-se na teoria marxista. ${ }^{67}$ Pode-se dizer que essa conferência deu concreção para aquilo que os artistas e a crítica nacional apenas sondavam para além dos limites do território das artes. Em parte, a condição retardatária da crítica brasileira no reconhecimento dos problemas sociais é explicada pela repercussão que as propostas da Semana de Arte Moderna tinham ainda no meio cultural e artístico do início dos anos trinta. Logo a tendência de ênfase sobre a temática social ecoaria com força entre críticos e artistas plásticos brasileiros, principalmente depois do reconhecimento artístico das gravuras de Lívio Abramo e das pinturas de Cândido Portinari.

A conferência de Mário Pedrosa sobre Käthe Kollwitz divide-se em três partes cujos assuntos principais são respectivamente: a correspondência entre a atividade

\footnotetext{
${ }^{66}$ ZANINI, W. A arte no Brasil nas décadas de 1930-40 - O grupo Santa Helena. São Paulo: Nobel \& Editora da Universidade de São Paulo, 1991, pp. 78-79. (parênteses nossos).

${ }^{67}$ Otília Arantes esclarece que: “(...) fez data (...) a conferência de apresentação da artista (Käthe Kollwitz) proferida por Mário Pedrosa - alguém tentava pela primeira vez, no Brasil, de modo sistemático e razoavelmente articulado, (...) uma interpretação marxista da arte.” ARANTES, O. B. F. Op. cit., p. 34. (parênteses nossos).
} 
artística e o modo de produção, o caráter social da arte e o posicionamento dos artistas frente aos problemas sociais e políticos de sua época. Em sua análise, Pedrosa visava sobretudo recuperar o sentido da função social na arte moderna e defender a mensagem política da arte. Ele discutia o afastamento da experiência estética do conjunto das atividades sociais e concluía que a humanização da arte dependia necessariamente da desalienação completa do trabalho social e da superação dos novos constrangimentos sociais e técnicos da era atual. Assim, a única saída viável para a arte seria reabilitar sua função social e laborar para a integração da experiência humana cindida pela divisão da sociedade em classes. Essa equação difícil, porém essencial, entre a reabilitação da função social da arte e a necessidade de transformação da sociedade para a realização plena da arte somente poderia ser solucionada através do posicionamento político e consciente dos artistas.

Pedrosa iniciava sua conferência com uma profissão de fé na revolução comunista e alertava os espectadores que, em nossa época, os fenômenos estéticos assim como o destino da arte estavam vinculados ao curso derradeiro do processo social como um todo: "A arte não goza de imunidades especiais contra as taras da sociedade, nem no seu pórtico param, sem transpô-lo, os prejuízos e as contingências mesquinhas ou trágicas do egoísmo de classe. Como outra qualquer manifestação social, é ela corroída interiormente pelo determinismo histórico da luta entre os diversos grupos sociais."68 Com o aumento do antagonismo de classes no regime capitalista, a arte deixava de ser o resultado de uma experiência comum entre os membros de uma comunidade para tornar-se a expressão de um ponto de vista particular e de classe sobre o modo de organização e de vida na sociedade. Se, por um lado, a arte perdeu seu sentido de experiência comum, por outro, ela não deixou de estar submetida ao determinismo histórico que a une com o processo social como um todo. É justamente a partir da constatação desse estado de coisas que se revelava o caráter social da arte hoje e a sua função sintetizada na opção de combate ou não em favor da transformação das condições de vida.

A constatação de que a arte partilha do mesmo destino do processo social como um todo permite que se retire dela a aura de atividade inefável para definir, em bases mais concretas, sua identidade com as demais atividades sociais. Diz Mário Pedrosa: "Sendo o fenômeno estético uma atividade social como outra qualquer, está por isso

\footnotetext{
${ }^{68}$ PEDROSA, M. "As tendências sociais da arte e Käthe Kollwitz" In Política das Artes (org. Otília Beatriz Fiori Arantes). São Paulo: EDUSP, 1995, p. 36.
} 
mesmo situado pelo conjunto de todas as outras manifestações da sociedade, isto é, por uma determinada civilização. ${ }^{, 69}$ Com isso, Pedrosa indicava que a compreensão do fenômeno estético ou da atividade artística não se faria sem um estudo específico da sociedade em que ela surgiu. Essa posição remetia à necessidade de uma abordagem sociológica da arte, que tomasse como base a comparação da organização e do desenvolvimento de vários estágios das sociedades primitivas com a sociedade capitalista $^{70}$. Para tal fim, como critério de análise objetiva da identidade existente entre a arte e o conjunto das atividades sociais, Pedrosa recorreu ao modo de produção para esclarecer de que maneira, inserindo-se no desenvolvimento histórico e participando de um processo de constituição comum, a arte separou-se do conjunto das outras atividades sociais.

$\mathrm{Na}$ primeira parte de sua conferência, Mário Pedrosa adotava a teoria marxista sobre as leis do desenvolvimento da sociedade, isto é, o materialismo histórico, para explicar a origem e a natureza do fenômeno artístico. Dessa forma, Pedrosa partia não das idéias elaboradas para legitimar o modo de associação entre os homens numa determinada sociedade, mas das condições materiais da vida provenientes da organização do trabalho social. Ele chegava, assim, à caracterização das forças produtivas e das relações de produção nos diversos estágios das sociedades desde as mais primitivas até as mais complexas. Na verdade, a preocupação de Pedrosa era comparar o sentido social do trabalho entre os povos ditos primitivos e a sociedade capitalista moderna e, a partir daí explicar o fenômeno artístico. Os povos primitivos gozavam de uma situação comum relativamente à produção de bens materiais, pois os instrumentos e as técnicas de produção eram compartilhados e de conhecimento de todos. Vivendo em um estado de apoio e ajuda mútua, a experiência estética desses povos também era comum e não se distinguia, em importância, do restante das atividades sociais. Com o desenvolvimento das relações de propriedade dos meios de produção, o trabalho tornourse a condição de sobrevivência de uns e o consumo conspícuo de outros. Na sociedade capitalista, onde esse processo alcançou

\footnotetext{
${ }^{69}$ Idem, ibidem, p. 36.

${ }^{70}$ Otília B. F. Arantes expõe: "Mário Pedrosa se serve de toda uma conceituação marxista, de expressões tais como determinismo histórico, modos de produção etc., para refazer a história da arte do ponto de vista das relações homem-natureza de acordo com o itinerário básico do Capital. Mas essa não é a única fonte, quando mais não seja, pela ausência de uma estética propriamente dita nos textos de Marx e Engels. É quando vêm em socorro Hegel, Ernst Grosse ou Gottfried Semper (e Karl Bücker)." ARANTES, O. B. Fiori. Op. cit., p. 36. (parênteses nossos).
} 
desenvolvimento completo, tanto o trabalho como a arte perderam seu sentido social originário.

Apoiado em Ernst Grosse, Pedrosa demonstrava que nas sociedades ditas primitivas não havia uma divisão clara entre o trabalho social e a atividade artística, pois as habilidades técnicas aprimoradas para a caça e para a pesca eram úteis na feitura de uma escultura, de um desenho ou de uma pintura. Com a ampliação das aquisições técnicas ocorreu a passagem dessa primeira forma de agrupamento de caçadores e coletores para as sociedades agrícolas rudimentares. Nelas, ainda que houvesse um decréscimo do talento plástico, não foi rompido o vínculo existente entre a arte e as outras atividades sociais. Todos os que caçavam, coletavam víveres ou aravam a terra e criavam animais eram capazes também de produzir arte: "Eis porque, entre os povos primitivos, o talento artístico é generalizado, sendo mesmo o dos povos caçadores superior ao dos criadores e agricultores primitivos. (...) (E como diria Gottfried Semper,) entre os primitivos, a atividade artística era presa ao desenvolvimento da técnica, embora rudimentar, mas o contato do homem com a natureza era tão estreito que tinha uma aparência quase pessoal. Mal surgira então o primeiro utensílio para pôr uma separação entre o indivíduo e o meio ambiente. E por isso as formas de arte e os motivos estéticos eram determinados pelas formas naturais que interessavam mais direta e imediatamente ao próprio homem - a natureza viva, animal."

Em contato com a natureza, o homem atribuiu a ela um caráter pessoal ou, nos termos da Teoria da Gestalt, uma característica fisionômica para a aparência. Tudo lhe inspirava familiaridade e sua existência estava integrada ao sentido que ele construía na relação com as coisas. Sua compreensão do mundo, sua organização social e todas as suas atividades faziam parte de uma experiência única e comum. No caso da arte, essa seria a chave interpretativa de Pedrosa para diferenciar os povos primitivos e o estágio civilizacional posterior caracterizado pela separação crescente entre o homem e a natureza, em que as formas naturais foram substituídas por formas decorativas ou ornamentais. Os instrumentos- máquinas passaram a determinar as novas condições de trabalho na sociedade: "Esse processo é o que Marx chamou de 'formação dos órgãos produtivos do homem social'. (...) A tecnologia revela a atividade do homem perante a natureza, o processo imediato de produção de sua vida; por conseqüência, suas condições sociais e os conceitos intelectuais que dele jorram. (Conclui Pedrosa:) desde

\footnotetext{
${ }^{71}$ PEDROSA, M. “As tendências sociais da arte e Käthe Kollwitz” In Política das Artes (Org. Otília Beatriz Fiori Arantes). São Paulo: EDUSP, 1995, pp. 36-37. (parênteses nossos).
} 
que os instrumentos originais, saídos por assim dizer do organismo humano, transformaram-se em acessório de um novo aparelho mecânico, a sua forma tende a emancipar-se totalmente dos limites da força humana."

A distinção conceitual que Pedrosa faz em sua conferência entre uma experiência estética vinculada às condições humanas e outra derivada das imposições mecânicas do desenvolvimento técnico é fundamental para se compreender tanto os horizontes de sua crítica à arte sem função social como sua aposta na identificação da atividade artística com as demais atividades sociais. Tratava-se de reverter os determinismos históricos do momento presente e recuperar o sentido social da arte. Sem dúvida, o modo de vida dos povos primitivos e sua arte eram símbolos persuasivos da síntese possível entre trabalho e experiência estética nos limiares da transformação social, ao passo que a arte esvaziada de sentido social estava estreitamente ligada ao processo de alienação do trabalho e de perda do significado coletivo da experiência estética. Na sociedade capitalista, o trabalho se distanciou das condições humanas e a nova técnica passou a ditar a forma e o ritmo da produção: "O trabalho, que no início era adaptado a este (homem), começa a exigir, pelo contrário, que o homem se adapte a ele. O novo aparelho mecânico já não é mais o antigo utensílio acessório do organismo humano. Torna-se porém o instrumento de um outro instrumento mecânico. E o homem, manejador do primeiro utensílio, vai tornar-se depois um instrumento, manivela de um maquinismo que ele mesmo criou." ${ }^{, 73}$

O processo de alienação do trabalho completava-se e, no ápice desse processo, o homem deixava de ser sujeito para se tornar objeto da história: "Senhor, até então, de seu instrumento de ação sobre a natureza, isto é, seu trabalho, o homem é afinal apartado deste. $\mathrm{O}$ trabalho e o trabalhador começam a ter destino separado. O caráter social daquele despe-se dos restos de seu subjetivismo antropomórfico. O trabalhador perdeu a propriedade da produção, isto é, do resultado do seu trabalho. O modo de produção passou a ser cada vez mais indiferente ao próprio destino pessoal dos trabalhadores. As novas condições econômicas surgidas com a introdução da nova economia capitalista provocam por sua vez uma extraordinária revolução na técnica. As ciências físicas têm então extraordinário desenvolvimento. Começa a expirar a era da manufatura. (...) A produção da máquina por meio da máquina é instituída, ao apresentar-se o problema de produzir mecanicamente uma série de formas geométricas

\footnotetext{
${ }^{72}$ Idem, ibidem, p. 37. (parênteses nossos).

73 PEDROSA, M. Op. cit., p. 39. (parênteses nossos).
} 
necessárias às diversas partes da máquina (...). Chegava-se aqui ao fim do ciclo humano da técnica e da produção. A mão do homem foi definitivamente destituída de sua função condutora na produção." 74

Pedrosa não tinha uma visão pessimista sobre o desenvolvimento da civilização ou sobre a evolução da técnica, o que estava em questão era justamente o processo pelo qual as relações sociais se despersonalizaram e a exploração do trabalho pelo capital foi mantida em contradição com as conquistas técnicas que pareciam libertar o homem. Recuperar a função social da arte significava colocá-la a serviço da humanização da sociedade e do próprio homem e não sob a égide da técnica completamente despersonalizada ou das leis da mecânica na sociedade capitalista: "As formas em marcha para a abstração, acabam existindo por si mesmas, perdendo a ganga subjetiva com que nasceram. No mais alto grau de sua evolução, a forma é inteiramente determinada pelo princípio mecânico, tornando-se totalmente independente do antigo aspecto originário e tradicional de um instrumento primitivo que se transformou em máquina. Toda forma em seu início revela a sua origem humana e impressionista. As leis da estética seguem nesse sentido as leis da mecânica. E toda forma só encontra o seu apogeu quando é determinada pela função específica de sua matéria e do princípio vital desta. Pode-se dizer que ela evolui da sensibilidade para o pensamento abstrato."75

$\mathrm{Se}$, em um primeiro momento, a técnica parecia servir para a construção de uma nova sociedade, logo em seguida a divisão da sociedade em classes, o egoísmo da burguesia, pôs o homem novamente em grilhões. Nesse estágio final, o trabalho despersonalizado tornava-se o fastio da civilização e a arte separava-se de vez das atividades sociais. Perdida sua unidade com o trabalho, em suma sua função social, pouco restava à arte. Empobrecimento da experiência coletiva, do trabalho e da arte: "Desumanizado completamente o trabalho social, pouco a pouco despoetiza-se, e o seu ritmo não é mais determinado pelo esforço humano. Extravasando da medida do homem, cai sob as leis do mecânico. (...) É aqui que se apresenta, no desenvolvimento industrial moderno, o tremendo 'paradoxo': o mais poderoso dos meios de libertação do homem da escravização à natureza transforma-se no meio mais infalível de escravizar o homem, isto é, o operário, à sociedade, isto é, ao capital. (...) Eis aí o processo seguido

\footnotetext{
${ }^{74}$ Idem, ibidem, p. 40.

75 PEDROSA, M. Op. cit., p. 40.
} 
através da história nas relações entre o trabalho e a arte. A sua unidade originária foi perdida. A função social da arte decaiu. Abria-se a era do culto impessoal da forma.,"76

Na segunda parte de sua conferência, Pedrosa se ateve em explicar o caráter social da arte, que dependia das condições materiais e do modo de produção em uma determinada sociedade e que, contribuindo para a formação de uma concepção geral de mundo, ao mesmo tempo dela fazia parte. Nas sociedades mais organizadas, o caráter social da arte era definido, assim como a concepção geral de mundo, pelo equacionamento da relação entre natureza e sociedade. Pedrosa afirma que as primeiras concepções de mundo derivadas do modo de produção da sociedade, tais como a da Grécia antiga, formaram uma mitologia que seria a base para a criação artística. A primeira se constituía em visão totalitária de mundo expressa por uma classe dominante. Em casos posteriores como no período do Renascimento, o caráter social da arte não se realizaria sem a harmonização difícil entre a concepção de natureza e a de sociedade, já que se pronunciava o conflito entre classes. É justamente nesse momento que se verificou a substituição do caráter social e coletivo da arte por uma compreensão do mundo e uma caracterização da experiência artística centradas no indivíduo.

A partir do desenvolvimento da produção material e das relações de propriedade no capitalismo, a concepção de mundo e a experiência da arte foram divididas entre as classes sociais. Havia, por assim dizer, idéias e também experiências distintas para cada classe. Só uma nova concepção geral de mundo poderia solucionar tal situação. Enquanto classe dominante e capaz de impor por algum tempo sua visão, a burguesia forjava o antípoda canhestro de uma concepção geral, verdadeiramente coletiva, do mundo. Nesse sentido, também a arte perdia sua função pública, ocupava-se apenas dos dilemas e anseios individuais e se tornava objeto de prazer e de distração para poucos. Pedrosa explica: "A burguesia nascente, aglomerada nos centros urbanos em florescimento, acumulando riquezas sobre riquezas, segura de si e entusiasmada pelos seus triunfos econômicos, é ávida de gozo terreno, consumida por um frenesi dionisíaco de viver e de dominar. A finalidade econômica social da produção submete-se ao interesse individual. Surgem para a estética os problemas novos do desenvolvimento da personalidade, as grandes paixões do homem individual na sua relação com o seu próximo.",77

\footnotetext{
${ }^{76}$ Idem, ibidem, pp. 40-41.

77 PEDROSA, M. Op. cit., p. 43.
} 
Se, de um lado, a sociedade burguesa tornava possível com sua revolução técnico-científica uma abordagem racional da natureza, de outro, faltava uma nova visada sobre os problemas sociais. Eles requeriam a superação do individualismo burguês e a abolição da sociedade de classes. Cabia ao proletariado cumprir essa tarefa histórica e proporcionar a síntese da concepção de sociedade e de natureza, isto é, o surgimento de uma "nova concepção geral do mundo, em que tanto a sociedade como a natureza se integrem científica e harmoniosamente". ${ }^{78}$ Assim, o destino histórico da sociedade e sua visão coletiva do mundo bem como a função pública da arte dependiam da vitória final do proletariado na luta de classes. Diz Pedrosa: "Quanto ao conceito de sociedade, a teoria geral ainda em formação precisa, para impor-se definitivamente, vencer a batalha contra as formas da reação (...). Daí (o processo de) (...) individualização da imaginação moderna, que assinala a expressão artística de nossos dias. (...) os artistas modernos não fazem outra coisa do que inconscientemente extrair, não de uma mitologia, mas de uma concepção científica e racional da natureza, as formas e as realizações estéticas de suas criações." $" 79$

O processo de "individualização da imaginação moderna" resultava da falta de uma concepção geral de mundo, sendo que essa última se manifestava como reafirmação do indivíduo burguês contraposto ao plano social coletivo. Ainda que os artistas se apropriassem da concepção de natureza oferecida pelas ciências modernas para criar uma nova ordem artística, eles padeciam da perda da concepção de sociedade. Era louvável que os artistas se afastassem das soluções individuais e até abrissem mão provisoriamente das perscrutações mais prolíficas sobre concepções plásticas de espaço e de tempo a fim de divisar o esforço de construção coletiva de outra sociedade. Para que sua arte colaborasse na construção da idéia e da experiência de mundo, era preciso posicionamento no conflito de classes. A arte moderna deveria assumir "uma forma classista de consciência pública" e direcionar sua posição crítica contra os valores da sociedade capitalista baseada na técnica despersonalizada e no trabalho submetido ao imperativo mecânico. Só assim, a arte e os artistas recuperariam suas funções eminentemente sociais.

A arte moderna realizar-se-ia em duas vias possíveis: ou continuar seu aprimoramento técnico e de questões exclusivas do campo artístico, ou aproximar-se das ações candentes de sua época, fazer a crítica dos valores estabelecidos e fundar sua

\footnotetext{
${ }^{78}$ Idem, ibidem, p. 44.

${ }^{79}$ PEDROSA, M. Op. cit., p. 44. (parênteses nossos).
} 
prática no esforço da transformação social que posicionasse novamente o homem no centro das decisões históricas. Por isso, a arte assim como o homem eram instados a se posicionar e a decidir o rumo de seus destinos. Segundo Pedrosa, a independência da arte revelava-se na opção feita pelos artistas, porque o campo artístico estava dividido estética e socialmente: "de um lado, a arte desses criadores que ficaram absorvidos por essa segunda natureza superposta à primitiva que é nossa natureza moderna e mecânica - a técnica - e desligados completamente da sociedade, em parte por estreiteza mental, em parte para não tomar uma atitude em frente à implacável batalha das duas classes inimigas. (...) Voltam passadisticamente à torre de marfim, no meio das fabulosas miragens de aço que os rodeiam. No outro lado, colocam-se os artistas sociais, aqueles que se aproximam do proletariado e, numa antecipação intuitiva da sensibilidade, divisam a síntese futura entre a natureza e a sociedade. (...) É o caso de Käthe Kollwitz ",80

Embora muitos progressos tivessem ocorrido na arte moderna devido à sua apropriação das conquistas da ciência, eles não garantiam uma reviravolta completa dos fundamentos da sociedade burguesa e atuavam no interior da ordem social conservadora. A atividade crítica e independente da arte se efetivaria com a crítica dos condicionamentos e valores que negavam a reabilitação do sentido vital que ligava a arte com a sociedade. Pedrosa afirma: "Já Wagner, depois da tormenta revolucionária de 1848, dizia: 'Na época de sua floração, a arte nos gregos era conservadora, porque se apresentava à consciência pública como uma expressão válida e conforme. Entre nós, a arte verdadeira é revolucionária, pois só existe em oposição aos valores geralmente admitidos'. Em nossos dias, a arte só poderá ser restaurada na sua dignidade antiga e representar uma função social, embora talvez com prejuízo de sua pureza estética, se se opuser aos valores admitidos. Na sociedade cortada pelo mais terrível antagonismo de classes, só atingirá a consciência pública, ou pelo menos uma forma classista de consciência, (...) sendo revolucionária." ${ }^{81}$

$\mathrm{Na}$ terceira parte de sua conferência, Pedrosa analisou a trajetória artística de Käthe Kollwitz. Muito mais ligada à expressão gráfica do que à cor, a artista alemã conseguia adequar, como poucos, a escolha técnica aos temas de suas obras. A linha, feita com grafite ou com carvão, maculava de forma precisa a superfície do papel dando-lhe vida. Os vincos na madeira ou na chapa metálica de impressão captavam

\footnotetext{
${ }^{80}$ PEDROSA, M. Op. cit., pp. 46-48.

${ }^{81}$ Idem, ibidem, p. 44.
} 
melhor, que na aquarela ou que no óleo, as marcas de sofrimento nos rostos e nos corpos e os farrapos das roupas ou dos calçados gastos com que os proletários se vestiam. A utilização do contraste entre o preto da composição e o branco do papel, o uso do grafismo para a execução das tonalidades e, por conseguinte, para a elaboração dos volumes das figuras permitiam que a artista criasse em suas obras uma atmosfera sufocante e sombria. Ali, se encontravam homens, mulheres e crianças que tinham perdido sua qualidade humana. Não era possível reconhecê-los individualmente e as suas vidas pareciam incertas. Entretanto, sem muita claridade no interior da composição e sem um horizonte visual amplo, as figuras humanas ganhavam realce no entorno indefinido. Saiam do anonimato. Não era para menos, o homem e seu destino consistiam nas temáticas principais da artista.

Ao contrário dos artistas modernos que se submeteram à técnica e à máquina, Käthe Kollwitz recuperava a figuração humana em suas obras. Seus temas favoritos eram: os operários, a guerra, a figura da mulher e a da mãe com seus filhos. Em todos eles destaca-se a preocupação social. A artista tomava posição frente aos problemas sociais e políticos de sua época em favor do proletariado e, por isso, sua arte era tendenciosa. Pedrosa comenta: "Tudo que há de vital e embrionário dentro da atual sociedade não se sujeita mais a esta subordinação indigna à máquina. Os tempos dessa subordinação já passaram. Homens novos reclamam hoje novamente a restauração do seu primado sobre a entidade mecânica sobre-humana e gigantesca que eles mesmos criaram." ${ }^{82}$ As obras de Käthe Kollwitz exprimiam o anseio pela ransformação da sociedade, mas não eram exemplos da realização da arte na sociedade socialista. Embora elas indicassem que a temática social tornara-se um imperativo para a arte moderna, a verdadeira arte socialista surgiria da síntese dos temas sociais com a pesquisa plástica pura ou com os motivos técnicos impessoais: “(...) Os motivos sociais (...) tornam-se cada vez mais ricos e pedem a sua integração na obra artística moderna. (...) (Eles atingirão) um equilíbrio interior mais profundo, integrados aos motivos técnicos" 83 .

As obras de Käthe Kollwitz eram testemunhos vivos da crise do capitalismo e da mensagem de humanização da arte e do próprio homem trazida pelos operários que fazem a revolução comunista: "Dentro da sociedade burguesa, uma outra sociedade se forma, nos subterrâneos das minas, nos cortiços e nas aglomerações suburbanas, sob os

\footnotetext{
${ }^{82}$ PEDROSA, M. Op. cit., p. 48.

${ }^{83}$ Idem, ibidem, p. 48. (parênteses nossos).
} 
tetos das grandes usinas, nas cavernas das forjas e das caldeiras, no bojo das máquinas, ao contato dos motores. E ela tem a chave do mundo nas suas mãos grosseiras e encarvoadas. É este o único grupo social nascido com a máquina, despojado por ela, mas o único capaz de entender o seu segredo e que porá a sua grande mão violenta sobre o volante vertiginoso e selvagem do maquinismo (...). Este mundo novo obriga todos os homens que ainda restam de fora a uma determinada posição social. O destino da arte de Käthe Kollwitz não está, pois, na própria arte. Está socialmente no proletariado. É uma arte partidária e tendenciosa. Mas que assombrosa universalização! (...) o que ela aspira através da miserável opressão da hora presente é um novo humanismo superior." $\$ 44$

Nem a dualidade burguesa nem as idéias falsas de colaboração possível entre classes, em benefício de governos nacionalistas, perturbaram as convicções e as predileções artísticas de Käthe Kollwitz. Desde o início de sua trajetória, a artista optou por representar as angústias e as dores do proletariado. Nesse momento histórico, sua arte continha mais verdade sobre os acontecimentos que afligiam o homem moderno. Um caso disso são as composições que tratam dos horrores da guerra. Enquanto o burguês falseia o sentido da realidade: "vista pelo povo, (...) sentida pelo proletariado, (a guerra) sem deformação ideológica ou tendenciosa, sem a ignóbil masturbação patriótica com que é exaltada, sem reclame de soldados desconhecidos nem de heróis de opereta, sem glória, sem generais gordos e estrelados, sem anjos da guarda nem senhoras caridosas que mandam bombons e cigarros para as trincheiras. A guerra de Kollwitz só tem sacrifícios anônimos e monstruosos, só tem viúvas a quem não resta mais nada, na miséria e na dor", e Pedrosa conclui: "não há arte, não há proeza estética, (...) que consiga exprimir a mesma intensidade emotiva, a mesma universalidade, colocando-se (...) (na) posição social da burguesia." 85

A figura da mulher e das mães com seus filhos constituíram também temas de muita importância nas obras de Käthe Kollwitz. Ela se identifica com as angústias da mulher proletária e com os sofrimentos das mães que perderam seus filhos na guerra ou que não podem alimentá-los. No tratamento desses temas, Pedrosa observa uma inovação formal, pois Kollwitz se afasta do traço naturalista e incorpora elementos da arte de vanguarda, em especial do expressionismo. Com isso, os temas perdem em descrição fidedigna de detalhes o que ganham em universalização: "Essa profundeza

\footnotetext{
${ }^{84}$ PEDROSA, M. Op. cit., p. 49. (parênteses nossos).

${ }^{85}$ Idem, ibidem, p. 50.
} 
que (Käthe Kollwitz) mostra é um dos traços femininos mais típicos de sua sensibilidade. E talvez explique a ausência da classe inimiga nas suas gravuras. Esta só aparece nelas de modo indireto. Aparece sob a forma de uma fatalidade social. Aquele ambiente tenebroso em que são envolvidas as suas figuras representa a fatalidade social da classe inimiga; aquela vida dolorosa e trágica de sua gente trai a reação feminina de sua sensibilidade que é puramente instintiva e sentimental. A mulher proletária ainda não ultrapassou essa fase primitiva de consciência de classe. A ausência de qualquer vestígio da natureza já demonstra porém que todos os males vêm da sociedade, vêm dos homens.",86

A arte de Käthe Kollwitz era a melhor expressão de uma arte proletária, partidária e interessada na revolução. Por negar o conceito de humanidade para explicar a crise da sociedade atual, a arte tendenciosa de Kollwitz tem muito mais humanidade pois propõe recuperar a humanidade da arte e do homem - que qualquer outra expressão artística habituada ao status quo: "Interessada e tendenciosa como é, partidária por sistema, não há entretanto arte mais profundamente humana." ${ }^{~} 87$ Se o proletariado usaria a crítica das armas para fazer a revolução, a arte tendenciosa seria a arma da crítica contra as mazelas do regime capitalista. É preciso frisar que, ocorrida a revolução, tanto o proletariado se extinguiria como classe quanto a arte proletária deixaria de existir. Assim como Leon Trotski, Pedrosa acreditava que a arte proletária servia à causa da revolução, mas não seria a expressão da sociedade futura: “O proletariado é uma classe transitória. A sua existência está condicionada a uma luta constante e terrível pela vida. Não lhe sobram momentos para ensarilhar as armas e entregar-se aos prazeres da contemplação e da imaginação gratuita. A sua arte tem que ser também transitória e utilitária. Até agora, a expressão mais nobre dela é Käthe Kollwitz." ${ }^{, 8}$

\footnotetext{
${ }^{86}$ PEDROSA, M. Op. cit., p. 53. (parênteses nossos).

${ }^{87}$ Idem, ibidem, p. 56.

88 Idem ibidem, pp. 54-56. Eis o que Trotski diz, ao refutar as principais argumentações dos proletkultistas (adeptos da cultura proletária): "Cada classe dominante cria sua cultura e, em consequiência, sua arte. A história conheceu as culturas escravistas da antiguidade clássica e do Oriente, a cultura feudal da Europa medieval e a cultura burguesa que hoje domina o mundo. Daí, a dedução de que o proletariado deva também criar a sua cultura e a sua arte. (...) O proletariado terá muito tempo para criar uma cultura proletária? (...) pode o proletariado, nesse lapso de tempo, criar uma nova cultura? (Essas dúvidas são legítimas), porque os anos da revolução social serão anos de uma feroz luta de classes, na qual a destruição ocupará maior lugar que a atividade construtiva. O proletariado, em todo caso, gastará a sua energia principalmente na conquista do poder, na sua manutenção, no seu fortalecimento e na sua utilização para as mais urgentes necessidades da existência e da luta posterior. Ora, durante esse período revolucionário, que encerra em limites tão estreitos a possibilidade de uma edificação cultural planificada, o proletariado atingirá o clímax de sua tensão e dará a manifestação mais completa do seu caráter de classe. E, inversamente, quanto mais o novo regime estiver protegido contra perturbações militares e políticas e quanto mais favoráveis se tornarem as condições para a criação cultural, tanto mais o
} 
Como diria Trotski, na polêmica com os proletkultistas, não era possível imaginar que um esquema criativo aplicado para a avaliação e para a denúncia das condições sociais reais servisse para a arte, a fim de extrair dela uma linha precisa e definitiva de desenvolvimento futuro. A arte proletária não era a arte da sociedade socialista. No que concerne a esse assunto, antes do ano de 1924, Bukharin já travara um debate amplo com Trotski e Lênin sobre o tema da cultura proletária. Tanto Trotski como Lênin defendiam a importância das criações humanas do passado, seus bens culturais e em particular sua arte, ao passo que Bukharin considerava toda a cultura burguesa como nociva ao desenvolvimento dos ideais comunistas. Embora esse debate levantasse questões interessantes sobre a relação entre política cultural e liberdade criativa e sobre as origens sociais da arte, a sua solução se deu pela advertência de Lênin e Trotski sobre o curso necessário da revolução proletária. A resposta à legitimidade do movimento para consolidação de uma cultura própria do proletariado foi estritamente política: o caráter transitório do proletariado.

Para Bukharin, não era possível dar continuidade aos padrões culturais burgueses na sociedade socialista, do que não discordavam os velhos líderes da Revolução Soviética, Lênin e Trotski. Mas até que ponto a revolução tinha estabelecido uma verdadeira sociedade socialista? Encontrava-se aí o centro do problema, na proposta de Bukhárin de incentivar a formação de uma cultura genuinamente proletária. Pelo que se sabe, Lênin contestou com veemência as decisões do Congresso de Cultura Proletária de 1920. Em um discurso pronunciado no III Congresso da União das Juventudes Comunistas da Rússia, em 2 de outubro daquele ano, Lênin dizia que a cultura proletária não passaria a existir por um passe de mágica, mas se construiria "conhecendo com precisão a cultura que criou a humanidade". ${ }^{89}$ Por isso, a atitude dos proletkultistas de abandonar toda a herança cultural era um erro torpe. Como afirmou Lênin aos jovens reunidos no Congresso, não se tratava apenas de promover uma assimilação de valores, vazia. Era preciso evitar tanto a reprodução de conteúdos e a atividade mental não-reflexiva como a auto-satisfação da consciência produzida unicamente pelo posicionamento político.

proletariado se dissolverá na comunidade socialista, libertar-se-á de suas características de classe, isto é, deixará de ser proletariado”. TROTSKI, L. Literatura e revolução. Rio de Janeiro: Zahar Editores, 1980, pp. 161-162. (parênteses nossos). Cf. também: STRADA, V. "Do realismo socialista ao zdhanovismo" In História do marxismo; o marxismo na época da terceira internacional: problemas da cultura e da ideologia. (Org. Eric J. Hobsbawn). Rio de Janeiro: Paz e Terra, 1987, pp. 143-146.

${ }^{89}$ LÊNIN, V. I. La literatura y el arte. Moscou: Editorial Progresso, 1979, pp. 267-268. 
Talvez Trotski tenha tratado o tema da cultura proletária de forma mais direta, a ponto de não deixar dúvidas quanto ao significado do termo e sobre sua validade. Para ele, dado seu caráter histórico, o proletariado não tinha condições de formar uma cultura legítima. Ocupado com a defesa e a luta ferrenha contra seu inimigo histórico, o proletariado não teria chance de aprimorar uma cultura própria e distinta da cultura burguesa. Sendo assim, a construção de uma nova cultura seria obra de um movimento paulatino que viria em conjunto com a elevação educacional das massas e com o surgimento de condições muito mais favoráveis ao labor criativo. Trotski concluía que, quando chegar o período da vitória completa da revolução, o proletariado não existirá mais como classe e, por isso, a nova cultura não será proletária. Diz ele: "Se rejeitarmos o termo cultura proletária, que fazer então com o proletkult? Convenhamos então que proletkult significa atividade cultural do proletariado, isto é, a luta encarniçada para elevar o nível cultural da classe operária. Tal interpretação, na verdade, não diminui em nada a sua importância." $" 90$

Além do esforço dos proletkultistas para a elevação cultural do proletariado, Trotski diz que toda forma de arte "enriquece a experiência espiritual do indivíduo e da coletividade, apura o sentimento, torna-o mais flexível, mais sensível" e que o proletariado deveria ter oportunidade de conhecer a arte burguesa, "integrada para sempre no patrimônio da humanidade". ${ }^{91}$ Não era possível imaginar a construção da sociedade socialista sem uma educação estética do homem. Essa educação se iniciava com a assimilação da cultura do passado e com os esforços presentes. Ao contrário dos proletkultistas que condenavam o individualismo da arte e da cultura burguesas, Trotski explicava que artistas, tais como Gorki, contribuíram para a revolução: "Há individualismo e individualismo. (...) Gorki, imbuído do individualismo romântico do vagabundo, soube nutrir o espírito primaveril da revolução prole tária nas vésperas de 1905, porque ajudou a despertar a personalidade numa classe em que a personalidade, uma vez despertada, procura relacionar-se com outras personalidades despertadas. $\mathrm{O}$ proletariado necessita de alimentação e educação artísticas.",92

Mário Pedrosa tinha em conta a análise de Trotski quando proferiu a conferência sobre Käthe Kollwitz. Tanto Pedrosa como Trotski afirmavam que a arte na sociedade socialista recuperaria seu significado social. Ela não seria arte proletária nem arte

\footnotetext{
${ }^{90}$ TROTSKI, L. Literatura e revolução. Rio de Janeiro: Zahar Editores, 1980, p. 177.

${ }^{91}$ Idem, ibidem, p. 148 e 166.

92 Idem, ibidem, pp. 192-193.
} 
burguesa. Enquanto a sociedade não se transformasse, a independência da arte consistia em sua luta a favor da revolução e contra os valores admitidos. Assim como Trotski, Pedrosa não dizia que a arte proletária era a única alternativa legítima e viável para a revolução. Mesmo os artistas burgueses de posições individualistas, se se aproximassem do proletariado, poderiam contribuir para a transformação da sociedade. Porém, era preciso avaliar que a contribuição dos intelectuais e dos artistas advinha da criatividade artística ou invenção formal aliada ao posicionamento político. O destino da arte e o da sociedade estavam em jogo. Daí a necessidade de uma crítica radical de todos os valores. Uma crítica dos valores artísticos e dos valores sociais e políticos, pois a revolução comunista simbolizava uma alteração profunda da sociedade capitalista.

No ano de 1933, de luta encarniçada contra o capitalismo e contra a ascensão do fascismo, era imprescindível que os artistas se posicionassem em favor da revolução comunista. Tanto no plano internacional como no nacional, as alternativas de convivência dos interesses da pesquisa puramente plástica com os debates políticos pareciam demasiado ingênuas, pois elas enfrentavam forças organizadas e a parafernália de propaganda nacionalista dos governos conservadores. Para piorar ainda mais o terreno movediço das transformações políticas e sociais, estavam em voga crescente as ideologias da colaboração entre classes veiculadas pelo fascismo na Europa e também como se viu mais atrás - pelo governo de Getúlio Vargas no Brasil. Essas ideologias não confundiam apenas os movimentos reivindicatórios dos trabalhadores, que precisavam ser controlados, mas também setores dos artistas e da intelectualidade. As idéias dividiam os homens e as artes não podiam os integrar de novo. A conferência de Pedrosa foi a contrapartida crítica dessa situação. Nela, ele enfatizou as diferenças entre as classes, a luta do proletariado como momento consciente de transformação histórica e a posição das artes no interior dos conflitos sociais e políticos.

Segundo Pedrosa, a posição de independência da arte moderna não provinha (naquele momento de crise política e social) de suas invenções formais, mas de sua capacidade em formular uma crítica consistente de todos os valores da sociedade conservadora, já que a luta da arte por sua liberdade de pesquisa passava primeiro pela recuperação de seu sentido social. O lugar de atuação dos artistas estava definido. Pedrosa fala sobre eles, que "(a grande maioria deles) ainda não vence(u) dentro de si mesmos a profunda antinomia filosófico-social que domina nossa época. E é o impasse 
de onde não podem sair. Os seus esforços são grandes mas unilaterais". ${ }^{93}$ Os artistas eram tolhidos porque sua arte perdera função social, mas ao mesmo tempo ela era um presságio da sociedade futura: "A simultaneidade e a generalização do movimento chamado de arte moderna, por toda a parte e através de todas as diferenciações episódicas ou parciais, mostram o seu caráter social verdadeiro. Não foi capricho individual de ninguém nem movimento superficial da moda. Foi um momento na evolução histórica da estética e uma imposição das forças produtivas e culturais da época."94 Ainda que a arte moderna fosse um processo de solução definitiva entre a forma novíssima e o conteúdo social da nova época, ele "continua inacabado e não passará de um processo evolutivo, marcado pela dualidade burguesa, e sua concepção puramente natural ou técnica deixa ainda de fora a sociedade". 95

Pedrosa sabia que por causa da pesquisa plástica e da pureza estética, a arte moderna tinha dado um salto qualitativo em relação à arte do passado e já apontava para a realização de um novo estado de consciência ou para "uma forma social mais nobre", mesmo assim ele aventava a proposta de ênfase do conteúdo sobre a forma para que as obras de arte pudessem alcançar a consciência pública. A arte vivia um paradoxo em que seu maior contributo, a saber, a renovação dos elementos plásticos e a revolução dos valores estéticos não bastavam. Era justamente no terreno da política que se encontrava a solução dos impasses daquela época. Em outras palavras, a recuperação do sentido social da arte dependia da transformação da sociedade e, por isso, a arte precisava colaborar com o proletariado. Ela possuía uma tarefa histórica. ${ }^{96} \mathrm{Com}$ a revolução e o assentamento da sociedade socialista, a arte ganharia novo sentido social e novos estímulos. Estava por se realizar uma dialética histórica da negação do falso estatuto de liberdade na arte moderna e de sua filiação à causa da política revolucionária para a realização final e plena da arte na sociedade futura.

Em 1934, Mário Pedrosa escreveu o artigo “impressões de Portinari” para o jornal Diário da Noite. Nesse artigo, ressaltava-se a mesma preocupação com a função social da arte evidenciada na conferência sobre Käthe Kollwitz. Não era para menos, Portinari deixara as pesquisas plásticas de sua fase inicial sobre a vida em Brodósqui para encontrar a matéria social no Rio de Janeiro: "Portinari começou sua obra pagando

\footnotetext{
93 PEDROSA, M. "As tendências sociais da arte e Käthe Kollwitz" In Política das Artes (Org. Otília Beatriz Fiori Arantes). São Paulo: EDUSP, 1995, p. 45. (parênteses nossos).

${ }^{94}$ PEDROSA, M. Op. cit., p. 45.

95 Idem, ibidem, p. 45.

${ }^{96}$ Cf. Idem, ibidem, p. 50.
} 
tributo à sua terra, Brodósqui. Primeiro contato com a natureza, os homens, etc. (...) Seus primeiros quadros tratam das crianças de seu tempo. Ele as espalhou pela vastidão da terra roxa, da terra nova de Brodósqui (...). Os temas são ingênuos: crianças atrás do palhaço, circo de cavalinhos, cemitério pequenino no fundo, parecendo uma horta. Nesta vastidão marrom salpicada de claro-escuro e de acidentes de luz, ninguém distingue ninguém. (...) As reminiscências infantis satisfeitas, o artista mudou de cenário. Emigrado para a cidade, começou a ver a gente agora com maior curiosidade. Gente trepada pelos morros urbanos. Nesta posição, a gente fica mais exposta e ele principiou a enxergá-la com mais objetividade." ${ }^{, 97}$

Pedrosa descreveu a evolução criativa de Cândido Portinari como um processo de aproximação gradual com a realidade em que os personagens pouco reconhecíveis de suas primeiras obras agora se individualizavam. A figuração impera. Eram homens e mulheres simples que ganhavam reconhecimento, pois centrados na tela para visão do espectador. Além da individualização dos personagens, eles eram postos em primeiríssimo plano. Em geral, os personagens da fase pós-brodósquiana localizavam-se aquém da profundidade convencional de apresentação do retrato na pintura e isso proporcionava uma proximidade com os espectadores. Em contraposição ao retrato burguês que tentava ou dar dignidade sóbria ou exaltava qualidades morais (distinção, circunspecção, honradez, etc.) pelo afastamento intencional entre o retratado e o espectador, os personagens de Portinari se avizinhavam íntima ou familiarmente do espectador. Aqui, Pedrosa ressaltava o equacionamento da relação fundo-figura: “Aqueles homenzinhos indistintos continuaram no entanto a crescer, individualizaramse. Tornando-se adultos, isolam-se pouco a pouco uns dos outros, exigindo maior atenção, e vão chegando para a frente, para a frente, até tomarem como hoje o quadro todo, como querendo pular para fora. Que atração pela vida, pela realidade, terrena e social!" 98

Em fase subsequiente, Portinari investigou a estrutura plástica da tela e depurou a relação entre o espaço compositivo, com a geometrização dos planos, e a plasticidade emocional das figuras. Agora, o que interessava eram as formas possíveis de estruturar a pintura. Procurando as leis próprias da composição e uma expressão mais abstrata das formas - o que garantiu mais universalidade para as figuras na fase madura de Käthe

\footnotetext{
${ }^{97}$ PEDROSA, M. "Impressões de Portinari” In Acadêmicos e Modernos (Org. Otília Beatriz Fiori Arantes). São Paulo: EDUSP, 1998, p. 155.

${ }^{98}$ Idem, ibidem, p. 156.
} 
Kollwitz -, Portinari encontrou o "esquema da realidade". 99 Depois de conquistar a estrutura compositiva e de estabelecer um lugar adequado para a figura e para o fundo, o problema do Pintor consistia em solucionar os dilemas entre a estrutura descarnada da composição e o conteúdo, entre a estrutura e a matéria pictórica. Explica Pedrosa: "Ao idealismo formal, abstrato, que se revela nesta fase, se opõe uma nova contradição dialética, uma nova exigência da matéria. Esta é a fase do absolutismo da forma. Esse rigorismo formal construtivo se opõe à representação do conteúdo. À força de procurar a essência interior da forma, a unidade estrutural da composição, o conteúdo material (e social) se perdeu. Falta agora a realidade ponderável, concreta, da matéria."100

Portinari deslindou, assim, no aprimoramento técnico do modelado a solução para recuperar o conteúdo "material e social" em suas obras. Com essa técnica, o Pintor conseguia dar às suas figuras um tratamento plástico capaz de lhes acentuar a corporeidade e acentuar o peso. A matéria plástica modelada sobre as telas de Portinari assemelhava as figuras humanas com esculturas. Suas figuras enchiam-se de cor, do claro-escuro e de matéria luminosa. Pedrosa afirma, ao comentar a tela Café: "O modelado do cafezal, com aquelas linhas cruzadas representando as carreiras de cafeeiros, constitui uma trama da comunicabilidade de antenas, ligando as figuras e os céus entre si, e os integrando na mesma materialidade luminosa. (...) Em relação à fase anterior, ele (...) descobriu que as coisas, as figuras e o espaço se ligam num mesmo tecido compacto e materializado. A penetração das figuras, porém, ainda é epidérmica, e sua materialidade consiste sobretudo na nitidez dos seus contornos e na consistência luminosa e concreta de suas superfícies." 101 Sobre a tela Índia e Mulata, Pedrosa arremata: "Acentuando a intenção de pura corporeidade que domina este quadro, (...) o valor extra-plástico (social) surgiu assim independente da intenção imediata do artista." 102

Com esse artigo, além de apresentar Cândido Portinari como um dos grandes talentos da arte brasileira moderna, o objetivo de Pedrosa foi propor que o pintor resolvesse a principal contradição estrutural de suas obras, a saber: a relação difícil entre figura e fundo. Pedrosa diz: "suas figuras projetam-se brutalmente para fora, enquanto o fundo do quadro se enche de amplidão, perspectivas, horizontes, paisagens, céus, uma vida intensa de plenos e cores representando a natureza na sua expressão concreta e

\footnotetext{
${ }^{99}$ Idem, ibidem, p. 156.

${ }^{100}$ PEDROSA, M. Op. cit., p. 157.

${ }^{101}$ Idem, ibidem, p. 158.

102 Idem, ibidem, p. 158.
} 
social, a terra e o trabalho. É o que há de mais contrário à técnica e à estética do retrato e do quadro. Essa contradição porém é inevitável, isto é, dialética. É preciso toda a técnica pictórica - a ciência da composição - do artista, para ainda assim conseguir dentro destes limites aquela admirável criação que é o Preto da Enxada. É o apogeu de sua ascensão criadora. A unidade artística foi conquistada aqui passo a passo, como numa dura partida de xadrez. O artista jogou aqui, (...) com todos os recursos (...) recorrendo a outros meios estranhos da pintura mural, da escultura, do monumental." ${ }^{, 103}$

Nessa época, Mário Pedrosa estava muito interessado na arte revolucionária mexicana, principalmente de Diego Rivera e de David Alfaro Siqueiros - que dera uma palestra sobre muralismo no CAM. Com seu artigo, Pedrosa tentava convencer Portinari a abandonar de vez a pintura de cavalete e partir para a pintura mural. Essa última seria a expressão adequada para uma verdadeira arte social que estivesse ao alcance das massas: "Portinari está diante, talvez, de um impasse. Mas pode ser que seja também diante do futuro. A volta à grande arte sintética, presidida pela arquitetura, que foi perdida com o início da era capitalista, anuncia-se. A pintura já marcha para essa integração com o afresco e a pintura mural moderna. Portinari sente esta atração. Como se deu com Rivera, com a escola mexicana. Aliás, a matéria social o espreita. A condição de sua genialidade como pintor está ali. É como uma espécie de esfinge da lenda grega: trata-se para ele de 'decifrá-la' ou de ser 'devorado'". 104

Em 1935, Portinari participou de uma exposição no Instituto Carnegie de Pittsburgh, Estados Unidos. Ali, ele ganhou uma menção honrosa com seu quadro Café e tornou-se conhecido da crítica de arte internacional. Como ressaltara Pedrosa, a obra de Portinari atingia o ponto de transição possível da tela para o mural. Também alguns críticos norte-americanos notaram isso. Annateresa Fabris comenta: "A crítica norteamericana saúda unânime o sopro renovador da obra de Portinari. (...) Dorothy Kantner, do Pittsburg Sun Telegraph, destaca o valor expressivo da deformação portinariana: 'Cândido Portinari, pintor brasileiro, que obteve a segunda menção honrosa, conhece o valor das deformações para conseguir efeitos picturais. O seu quadro premiado Café, é excelentemente desenhado e rico em tons pardacentos e suaves verdes acinzentados. Os trabalhos da colheita de café apresentam deformações propositadas, mas o efeito aumenta a força e avigora a pintura. Poderia ser realizada com o tema uma interessante

\footnotetext{
${ }^{103}$ Idem, ibidem, p. 160.

${ }^{104}$ PEDROSA, M. Op. cit., p. 161.
} 
composição mural. (...) O Café, de Cândido Portinari, é a aparição espetacular do Brasil.",105

O interesse da crítica norte-americana por Portinari centrava-se no fato de que eles apreciavam não só o muralismo, mas também o realismo social. A partir do início da década de 1930, o muralismo mexicano tornara-se uma febre nos Estados Unidos. Por isso, os programas de apoio às artes e aos desempregados do governo Roosevelt (WPA-FAP) patrocinaram os artistas para fazerem murais com conotação "social", sem compromisso com os ideais revolucionários comunistas dos muralistas mexicanos e como parte da propaganda do trabalho realizado pelo governo na superação da crise econômica que assolava o país. A aclamação de Portinari como um dos mais importantes pintores da 'Arte Americana' viria posteriormente com uma série de exposições de suas obras em instituições norte-americanas e com a execução de pinturas murais para a Seção Hispânica da Biblioteca Nacional de Washington em 1941. Nessa data, Portinari e Pedrosa, que então residia nos Estados Unidos, retomam contato. Era preciso fazer uma avaliação do significado das obras e da tendência seguida por Portinari. Assim, Pedrosa escreveu, em 1942, um ensaio crítico sobre o percurso do pintor brasileiro, intitulado "Portinari: de Brodósqui aos murais de Washington".

\footnotetext{
${ }^{105}$ FABRIS, A. Portinari, pintor social. São Paulo: Editora perspectiva \& EDUSP, 1990, p. 10.
} 
Capítulo 2. O apelo trotskista e a defesa da arte independente 


\section{$\underline{\text { A virada de cento e oitenta graus na política externa da URSS }}$}

Em meados de 1935, realizoutse o VII Congresso do Comintern em Moscou. Nele, Georgy Dimitrov admitiu que, após a malograda revolução comunista na Alemanha e a vitória de Hitler, era necessária uma reorientação da política da Internacional Comunista e, por conseguinte, dos partidos comunistas. Dimitrov discursou sobre o fim do isolamento da vanguarda revolucionária e sobre a formulação tática da Frente Popular. ${ }^{106}$ Essa surgia como uma alternativa à 'Teoria do Terceiro Período' e propugnava, em princípio, uma aliança ampla contra o fascismo. Na prática, a aliança antifascista da Frente Popular consistiu na aproximação dos comunistas com seus antigos adversários: os socialistas, a socialdemocracia, os anarquistas, os intelectuais de esquerda e de centro, os liberais e setores "progressistas" da burguesia. Por isso, Dimitrov e outros dirigentes salientaram que os comunistas deveriam evitar divergências ideológicas com os demais membros da aliança e não enunciar, por motivos óbvios, a perspectiva possível de triunfo da revolução proletária ao final do conflito envolvendo as principais potências imperialistas.

Com sua plataforma de combate ferrenho ao comunismo, o fascismo era uma ameaça real para a sobrevivência da URSS. Ao contrário das invectivas contra todas as potências imperialistas, os dirigentes do Comintern no VII Congresso diferenciaram politicamente as democracias burguesas e os regimes fascistas. Paolo Spriano comenta: "Em 1935-38, introduziu-se uma distinção relevante, nas posições do movimento comunista, a propósito daqueles que são chamados de 'adversários' (e o termo compreende tradicionalmente [...] seja os fascistas, seja os social-democratas, anarquistas e republicanos). [...] O fascismo não é mais somente indicado como a forma mais reacionária, mais chauvinista, mais agressiva, da ditadura do capital financeiro, mas se torna um adversário de periculosidade diferente da dos outros. [...] No informe de Dimitrov [...] dividia-se o campo capitalista em Estados imperialistas adeptos da guerra - o regime nazista alemão e o militarista japonês - e em Estados igualmente

\footnotetext{
${ }^{106}$ Depois da curta vigência do pacto russo-germânico de não-agressão, entre 1939 e 1941, a estratégia da Frente Popular foi substituída pela da Frente Nacional.
} 
imperialistas, mas 'pacíficos', ou seja, desejosos de manter o status quo existente. Os primeiros constituem - dizia-se - o 'inimigo principal'."107

Não se tratava mais de considerar as democracias burguesas como regimes social-fascistas nem de advogar a luta de classe contra classe, a situação política pedia que se estabelecessem alianças entre classes, para combater a expansão das ligas e dos regimes fascistas, e que se firmassem acordos políticos e coalizões de forças militares com países como a França e a Inglaterra para defender a URSS. Por isso, os dirigentes do Comintern revisaram as posições da Internacional Comunista e distinguiram com clareza a etapa da revolução democrática, que combatia e erradicava a ameaça fascista, da etapa propriamente dita da revolução socialista. Spriano diz: "Em primeiro plano, punha-se a proclamada necessidade - e, portanto, a valorização - da defesa das liberdades democráticas por parte da classe operária. (...) Percebia-se - e isso atuava profundamente na consciência dos operários - o valor desta conquista (de luta) unitária. (...) Não casualmente é este o período no qual, para o Comintern, a recuperação do conceito de "revolução democrática" assume um significado novo. (...) Não se identifica, na verdade, (...) uma temática da sociedade de transição. (...) E também os dirigentes da Internacional reiteram a concepção dos dois tempos, bem distintos entre si, o da revolução democrática e o da revolução socialista."

A aproximação política com as democracias burguesas parecia ser a melhor alternativa para defe nder a URSS numa possível guerra. Isso explica porque, a partir de 1935, os dirigentes do Comintern transigiram sobre temas importantes tais como o da defesa da liberdade e o dos valores democráticos burgueses ou não aprofundaram mais a crítica sobre a desigualdade nas sociedades capitalistas. Nas palavras de Spriano: "É indubitável que tanta insistência posta pelos comunistas na delimitação do âmbito democrático do movimento de frente popular corresponde a preocupações da política exterior soviética, a qual considera que só não radicalizando a luta de classes na França e na Espanha é que se pode firmar uma aliança estatal entre a URSS e as democracias

\footnotetext{
107 SPRIANO, P. “O movimento comunista entre a guerra e o pós-guerra: 1938-1947” In História do marxismo. (Org. Eric J. Hobsbawn). (vol. X). Rio de Janeiro: Paz e Terra, 1987, pp. 133-134. (colchetes nossos).

108 Idem, ibidem, p. 134. (parênteses nossos). Continua Spriano: "Afirma-se, por exemplo, que a revolução democrática em curso na Espanha, tendo como protagonistas o proletariado e o campesinato pobre, não pode ser tipificada como revolução democrático-burguesa clássica. A classe operária, pegando em armas para defender a República Espanhola, lutando contra os fascistas, os grandes proprietários rurais e o capital financeiro, luta por erradicar as próprias raízes do fascismo, as bases sobre as quais ele se apóia socialmente, e modifica assim as relações entre as classes, embora sem dar vida a uma revolução socialista, historicamente não ainda na ordem do dia." Idem, ibidem, pp. 134-135.
} 
ocidentais, como baluarte contra a agressividade hitleriana. Isso não significa, por si só, que se tenha sufocado no nascedouro (...) um impulso para a revolução proletária, de que faltam, com efeito, muitas condições; mas é menos discutível a constatação de que a excessiva prudência (...) (do) Comintern (...) haja debilitado a força da (Frente Popular) ${ }^{\prime 109}$.

Se a perspectiva da revolução proletária era deixada em suspenso por falta de condições históricas, não por acaso a URSS foi aclamada e ficou conhecida pela opinião pública internacional como o primeiro país a combater abertamente o fascismo. Spriano confirma: "Sem que se deva falar de 'ideologia das frentes populares', uma vez que o espírito antifascista de massa que as anima transcende essa fórmula, o período marcado por esta experiência exprime contraposição de valores, socialistas e democráticos, por um lado, e, por outro, autoritários, militaristas, clericais, fascistas. (...) A capacidade expansiva do movimento comunista se capta nitidamente no 'filocomunismo' de uma parte tão substancial da juventude e da intelligentsia, da vanguarda literária e artística. O termo 'companheiros de viagem' ressoa como algo não instrumental, especialmente para uma nova geração que se bate pela causa da República Espanhola (...). Observe-se, nesta medida, a percepção da URSS que penetra no antifascismo militante, tanto na esquerda americana quanto no trabalhismo inglês ou na SFIO francesa." "10

Enquanto os comunistas se uniam com seus antigos adversários políticos nas frentes populares, ocorria a interdição dos debates no Comintern, a perda completa de autonomia dos partidos comunistas e da Internacional Comunista, que se burocratizava para atender interesses políticos exclusivos do Estado soviético. Acrescia-se a isso que, a partir de 1936, as oposições de esquerda e de centro bem como lideranças "não confiáveis" do exército foram liquidadas nos Tribunais de Moscou. Entretanto, muitos observadores não se opuseram à forma como Stálin resolvia os problemas políticos internos da URSS, por causa da grande contribuição dos comunistas na luta antifascista. Spriano diz: "Não obstante tudo o que permanece inconciliável ou inaceitável, a URSS aparece como o único Estado verdadeira e completamente antifascista, o único que ajuda maciçamente os republicanos espanhóis, e a tal ponto que até as repercussões negativas dos processos de Moscou, (...) são postas em surdina - nas áreas democráticas

\footnotetext{
109 SPRIANO, P. Op. cit., pp. 135-136. (parênteses nossos).

${ }^{110}$ Idem, ibidem, pp. 136-137.
} 
e trabalhistas - em homenagem à função insubstituível que se atribui à URSS na luta comum.",111

Eric Hobsbawm apresenta três motivos para a adesão ampla dos trabalhadores, da juventude de esquerda e, principalmente, dos intelectuais aos movimentos antifascistas: "Em primeiro lugar, o fascismo em si, [...] tornara-se a maior expressão internacional da direita. Os movimentos políticos fascistas [...] cresceram e se multiplicaram em muitos países. [...] Em segundo lugar, a ameaça do fascismo não se limitava de modo algum à esfera política. A questão em jogo - e ninguém se dava conta disso melhor do que os intelectuais - era o futuro de toda uma civilização. Se o fascismo pisoteava Marx, pisoteava igualmente Voltaire e John Stuart Mill. Rejeitava o liberalismo em todas as suas formas, com a mesma decisão implacável com que recusa o socialismo e o comunismo. [...] Em terceiro lugar [...], 'o fascismo significava a guerra'. A cada ano, depois de 1933, algum acontecimento o confirmava drasticamente: o putsch nazista na Áustria (1934) foi seguido pela guerra da Etiópia (1935), pela reocupação hitleriana da Renânia, pela guerra da Espanha (1936), pela invasão japonesa na China (1937), pela ocupação da Áustria e, finalmente, por Munique (1938)."112

Entretanto, a participação dos partidos comunistas ligados à Terceira Internacional no movimento antifascista mais amplo - que agregou elementos tanto de esquerda como de direita - produziu estarrecimento e profunda crise em seus militantes. Isso porque, no decorrer das conquistas e avanços de Hitler, as frentes populares deixaram de ser uma coalizão entre os comunistas e os demais segmentos políticos de centro e de esquerda para se tornar uma união ampla dos comunistas com liberais, com a burguesia e com governos que declarassem guerra às potências fascistas. Eric Hobsbawn comenta: "As dificuldades maiores surgiram quando o movimento comunista internacional adotou a política antifascista. As consequiências da passagem da linha de 'classe contra classe' à de sustentação do antifascismo (...) representou (uma mudança dramática) naquilo que a maior parte dos comunistas tinham aprendido a pensar e a crer na esfera da política. Seu credo havia sido formulado justamente em

\footnotetext{
${ }^{111}$ Idem, ibidem, p. 137.

112 HOBSBAWM, E. J. "Os intelectuais e o antifascismo" In História do marxismo: o marxismo na época da terceira internacional: proble mas da cultura e da ideologia. (Org. Eric J. Hobsbawn). (vol. IX). Rio de Janeiro: Paz e Terra, 1987, pp. 264-266. (colchetes nossos). Hobsbawn conclui sobre a ameaça fascista: "o que Hitler fazia constituía uma ameaça para todos. Esta ameaça foi dramatizada imediatamente pela abolição do regime constitucional e democrático, pelos campos de concentração, pelas queimas de livros, pela expulsão ou emigração em massa dos dissidentes políticos e dos judeus, inclusive a nata da vida intelectual alemã. Tudo o que a história do fascismo italiano até então tinha somente anunciado tornavase agora explícito e visível, mesmo para os olhos mais míopes.” Idem, ibidem, p. 265.
} 
contraposição ao liberalismo e à socialdemocracia, para proteger o bolchevismo voltado à revolução mundial - de qualquer contaminação de reformismo ou de compromisso com o status quo." 113

O Comintern se conciliava com os inimigos históricos não só do comunismo, mas da própria teoria marxista. Se, no início, a tática da Frente Popular de união dos comunistas com outras forças de centro e de esquerda foi responsável pelo rechaço da ascensão do fascismo em vários países, posteriormente a aproximação recomendada pelo Comintern com os liberais e com a burguesia "progressista" baralhou as ações e as perspectivas dos partidos comunistas e impediu a organização dos trabalhadores para a luta revolucionária contra o capitalismo. Segundo os dirigentes do Comintern, não era possível conciliar o combate ao fascismo com a revolução proletária, já que a URSS precisava naquele momento da aliança política com as democracias burguesas e de todo apoio externo possível para se defender. Por sua vez, muitos militantes e intelectuais de esquerda, que apoiaram os movimentos antifascistas, anteviram o desastre político e as conseqüências mais nefastas da nova tática das frentes populares e questionaram a facilidade com que a Internacional Comunista passava da luta acirrada contra o capitalismo para a aceitação dos regimes burgueses.

Isso comprometeu de maneira irremediável o movimento comunista internacional. Em nenhum país, o desdobramento tático das frentes populares teve consequiências tão graves e arruinou os movimentos de esquerda como nos Estados Unidos. Ali, o partido comunista americano se ligou ora com as forças retrógradas no campo da cultura e das artes, ora com os "progressistas" que ensejavam uma política internacional e belicista dos norte-americanos para o mundo. Alan Wald explica: "No começo de 1935, uma manobra na política do Partido Comunista tornou-se aparente. Não apenas o esperado renascimento cultural proletário falhara em se materializar, mas também a Internacional Comunista (...) (abandonava) sua política ultra-revolucionária do Terceiro Período de 1928-33. Depois da desastrosa consolidação do hitlerismo, facilitado pela recusa dos Comunistas em obter unidade de ação com os Social

\footnotetext{
${ }^{113}$ HOBSBAWM, E. J. Op. cit., p. 303. (parênteses nossos). Sem dúvida, a tática da Frente Popular visava também uma transição para o socialismo diferente do processo revolucionário experimentado na URSS. Essa transição se daria por meio da hegemonia das principais forças envolvidas na luta vitoriosa contra o fascismo, a saber: os operários, os camponeses e os membros do partido comunista. Em seu ensaio sobre os intelectuais e o movimento antifascista, Hobsbawm discorre sobre a alteração da estratégia adotada pelo Comintern para a revolução proletária. Não era mais possível imaginar uma revolução prole tária como aquela que aconteceu na Rússia. O comunista italiano, Palmiro Togliatti foi um dos idealizadores da nova perspectiva de chegada ao socialismo por etapas. Cf. HOBSBAWM, E. J. Op. cit., pp. 303-307.
} 
Democratas Alemães contra os Camisas Pardas, o partido começou a procurar uma aproximação defensiva com forças capitalistas 'progressistas' e liberais. Os clubes John Reed, fundados como organizações de trabalhadores e de intelectuais proletarizados que eram abertamente anti-capitalistas e partidários da União Soviética, foram peremptoriamente liquidados pelo partido em favor de formações como o Congresso de Escritores Americanos e a Liga de Escritores Americanos que tinham uma simpatia maior pelos liberais dentre os acadêmicos, os autores comerciais e os literatos."

A posição de Trotski destoava dos consensos e das unanimidades da época. Ele criticava tanto a conciliação de interesses de classe como a etapa da revolução democrática formuladas pelos dirigentes do Comintern e executadas nas frentes populares. Para Trotski, embora a formação de uma aliança ampla de combate das ligas fascistas fosse imprescindível, não se poderia perder de vista a chance de abertura da revolução proletária na luta contra o fascismo. Deutscher relata: “(Trotski) criticou a frente única tal como a praticavam Thorez e Blum, sob a alegação de que sua ação se limitava às manobras parlamentares e alianças eleitorais; e que não procurava despertar os trabalhadores para uma luta extra-parlamentar contra o fascismo, e que poderia ter aberto também a perspectiva da revolução socialista. Lançou seu sarcasmo contra o Comintern, que o denunciava por insistir com os socialistas e comunistas alemães para que, em conjunto, barrassem o caminho que Hitler trilhava para o poder e que agora, sem qualquer disfarce, adotava a frente única apenas para transformá-la numa tática de evasão, ‘cretinismo parlamentar' e oportunismo. (...) A Frente Popular - argumentou Trotski, não associaria a classe média inferior com os trabalhadores, mas abriria um abismo entre eles, porque as classes médias inferiores estavam voltando as costas para os radicais." 115

\footnotetext{
${ }^{114}$ WALD, A. M. The New York intellectuals: the rise and decline of the anti-stalinist left from the 1930s to the 1980s. North Carolina: The University of North Carolina Press, 1987, pp. 80-81. (parênteses nossos).

115 DEUTSCHER, I. Trotski - O profeta banido. Rio de Janeiro: Editora Civilização Brasileira, 1984, p. 289. (parênteses nossos). Isaac Deutscher conclui: "O fracasso final da Frente Popular justificaria a maioria das críticas de Trotski. No momento, porém, a ação conjunta socialista-comunista conseguiu fazer recuar as ligas fascistas, que jamais se recuperaram de sua derrota, e a frente popular inegavelmente despertou a classe operária durante certo tempo e deu tremendo impulso ao seu movimento. Só posteriormente a política da Frente Popular iria diminuir a energia dos trabalhadores, afastar a pequena burguesia e com isso levar o país à reação e prostração, com que a deflagração da Segunda Guerra Mundial a foi encontrar. Mas, em 1934-35, à medida que diminuía o perigo do fascismo, o apelo de Trotski em favor da ação extra-parlamentar e das milícias operárias parecia intempestivo, não tendo provocado nenhuma reação. Observando, de seu retiro nos Alpes, as primeiras manobras da Frente Popular, registrou em seu diário que 'esta ordem solapou a si mesma, sem qualquer esperança. Desmoronará com um mau-cheiro'. Apenas alguns anos se colocavam entre os triunfos da Frente Popular e o grande mau-cheiro do colapso de 1940.” Idem, ibidem, pp. 289-290.
} 


\section{A esquerda e a política governamental para as artes nos Estados Unidos}

Nos Estados Unidos, a tática da Frente Popular fez com que os stalinistas se aproximassem dos defensores da ideologia nacionalista. Em oposição à tendência dominante no Comintern antes de 1935, que identificava na classe proletária o surgimento de uma nova cultura anti-capitalista, os partidos comunistas espalhados pelo mundo reabilitavam a noção de cultura ocidental contra a barbárie fascista. Nessa mudança de estratégia política, também o Partido Comunista dos Estados Unidos da América tratou de defender a herança cultural norte-americana e de apoiar os ideais liberaldemocráticos que fundaram aquele país. Assim, os dirigentes do PCEUA se aproximavam mais e mais não só das classes médias mas também dos liberais e da burguesia nacional. ${ }^{116}$ Seguia-se aqui, sem questionamento, o exemplo da luta contra o fascismo na Europa, que conseguira em pouco tempo unificar diversas forças sociais principalmente em torno de metas e de valores comuns.

Para as artes, a adesão à Frente Popular significava dar prioridade aos temas nacionais, prosseguir com a tradição naturalista ou realista social norte-americana e se afastar das manifestações vanguardistas. Serge Guilbaut expõe a repercussão, no meio artístico e cultural, da proposta de 'americanização' da política, feita por Earl Browder, líder do PCEUA: "A idéia básica (do Primeiro Congresso de Artistas Americanos realizado em 14 de fevereiro de 1936) foi anunciada por Lewis Mumford, um escritor liberal, que salientou o estado catastrófico do mundo e então a importância da assembléia dos artistas, não apenas para possibilitar que eles se defendessem coletivamente contra a Depressão mas também (...) contra o fascismo (...). (Embora Stuart Davis mostrasse) que 'crescentemente, a expressão de problemas sociais

\footnotetext{
${ }^{116}$ Segundo Elizabeth G. Seaton, a estratégia da Frente Popular para a construção de um movimento antifascista amplo, que possibilitou a aliança instável entre a URSS e as democracias ocidentais, foi a alternativa dos comunistas para garantir direitos dos trabalhadores como o de livre associação. Seaton esclarece: "Durante o VII Congresso Mundial da internacional comu nista em Moscou em 1935, (...) Concluindo que eles (os comunistas) tinham falhado em entender o fascismo com a maior ameaça para a classe trabalhadora, os membros (...) decidiram se juntar a governos de esquerda e forças centristas das nações democráticas do Ocidente em uma aliança antifascista. Os Comunistas ainda declaravam que o capitalismo era "fascista", mas o PCA abrandou seus ataques contra as bases capitalistas da democracia americana. Os membros salientaram o objetivo de preservar liberdades suprimidas pelos governos fascistas, particularmente a liberdade de associação e de expressão.” SEATON, E. G. Federal prints and democratic culture: the graphic arts division of the Works Progress Administration Federal Art Project, 1935-1943. Tese de Doutorado. Northwestern University, Illinois, 2000, p. 66. (parênteses nossos).
} 
hodiernos na nova Arte Americana deixa claro que nos tempos em que nós estamos vivendo, poucos artistas podem permanecer indiferentes, envolvidos com problemas de seus estúdios', (ele concluía em favor da) rejeição do nacionalismo em pintura. (Ao contrário de Munford) (...) Davis salientou a idéia de que tais slogans populares como Save America for Democracy assim como o apelo de alguns intelectuais por um novo Americanismo era hipócrita e cheirava a nacionalismo fascista." 117

Contudo, Meyer Schapiro e Lynn Ward foram responsáveis pela análise mais consistente sobre os prejuízos da idéia de arte nacional apregoada pela Frente Popular. Em seu pronunciamento conjunto, intitulado "Raça, Nacionalidade e Arte" e apresentado no Primeiro Congresso de Artistas Americanos, eles diziam: "Nós temos muita simpatia por uma 'Arte Americana' em que o conceito de América é muito vago, frequentemente definido como uma 'expressão americana genuína' ou uma 'arte explicitamente nativa' (...). Em face disso, nós podemos reconhecer que a base real para uma separação emocional entre os membros da tribo e os de fora é encontrada nos mais ou menos obscuros sentimentos de rivalidade econômica e insegurança; que esta separação torna-se uma barreira efetiva para uma solução válida dos problemas que todos os artistas enfrentam; ... que finalmente a palavra 'Americana' usada daquele modo não tem significado real. Ela suspende um véu de unidade fictícia e cega nossos olhos para o fato que não pode haver arte em comum entre os Americanos do Rockefeller Center, os Americanos da Legião em Terre Haute, e simbolicamente os Americanos da Faculdade Nacional do Arkansas." 118

Schapiro e Ward apontavam em seu pronunciamento que a arte não se encontrava desvinculada dos interesses de classe e que esse era o principal motivo pelo qual se condenava a proposição falseadora e ambígua de uma arte nacional. Nesse período, Schapiro estava ainda muito interessado na arte realista que se empenhava na revolução social completa e, sendo assim, sua crítica se apoiou menos nos aspectos formais do que no significado político da mensagem estética endossada pelo PCEUA. A polêmica entre Meyer Schapiro e Jacob Burk, no Clube John Reed, sobre qual seria o campo artístico mais eficaz, a gravura ou a pintura, na conscientização das massas e na revolução é elucidativa da proposta de Schapiro e de muitos comunistas para as artes. Elizabeth Seaton relata: "(Schapiro criticara a exposição "A crise mundial expressada

\footnotetext{
117 GUILBAUT, S. How New York stole the idea of the modern art - abstract expressionism, freedom, and the cold war. Chicago: The University of Chicago Press, 1985, pp. 19-20. (parênteses nossos).

${ }^{118}$ SCHAPIRO, M. \& WARD, L. "Race, Nationality and Art", First American Congress, pp. 38-41 Apud GUILBAUT, S. Op. Cit., p. 21.
} 
na arte" de 1933). Segundo Schapiro, a exposição foi em parte mal-sucedida em exibir idéias revolucionárias por causa do enfoque de seus participantes na pintura. (...) (Ele) via como má orientação não apenas a adesão de membros à pintura de cavalete como uma arte 'social', mas também sua 'devoção à pintura mural'. Ele recomendou em vez disso o que Andrew Hemingway descreveu como um 'modelo agitprop de arte revolucionária', formas tais como pôsteres que já tinham estabelecido relações populares e políticas." 119

Ao mesmo tempo que se adotava a tática da Frente Popular nos Estados Unidos, a linha estética do realismo socialista se consolidava na URSS em 1934 e era difundida internacionalmente pelos partidos comunistas. Isso gerou certo desconforto para Schapiro e para muitos intelectuais ligados ao PCEUA, já que em sua maioria eles não viam como antagônicos os interesses pelo realismo, pela revolução social e também pela arte de vanguarda. Com a difusão da doutrina do realismo socialista, os stalinistas declaravam não ser exequíivel o vínculo entre a arte de vanguarda e o comunismo. A conseqüência disso para o cenário cultural norte-americano foi que o realismo passava a ser enfatizado na época não só pela política cultural norte-americana, mas também pelas diretrizes estéticas do PCEUA. Embora fossem concepções diferentes de realismo, o direcionamento tático da Frente Popular seguido pelo Partido Comunista aproximou-o mais da arte nacionalista incentivada pelo governo de Franklin Delano Roosevelt através da Works Progress Administration - Federal Art Project (WPA-FAP) ${ }^{120}$ do que dos esforços despendidos por um Schapiro, por um William Phillips ou por um Philip Rahv a fim de conciliar teoria marxista e estética.

Daí em diante, a disputa da intelectualidade norte-americana de esquerda, sobretudo para aquela ligada ao PCEUA, estabeleceu-se entre os que apoiavam exclusiva e invariavelmente ou o naturalismo e o realismo social do New Deal ou a arte moderna. Por uma série de fatores, Phillips e Rahv, fundadores da Partisan Review, assim como Meyer Schapiro, se afastaram progressivamente do PCEUA, compuseram o movimento anti-stalinista de esquerda e se aproximaram do trotskismo em 1937. Alan Wald expõe a divergência de posição entre stalinistas e trotskistas no que se refere às técnicas e à temática das artes: "O que ajudou a diferenciar as críticas influenciadas

\footnotetext{
${ }^{119}$ SEATON, E. G. Federal prints and democratic culture: the graphic arts division of the Works Progress Administration Federal Art Project, 1935-1943. Tese de Doutorado. Northwestern University, Illinois, 2000, pp. 58-59. (parênteses e itálico nossos).

${ }^{120}$ Programas criados durante o New Deal: Administração do Progresso de Obras (WPA) e Projeto de Arte Federal (FAP).
} 
pelos trotskistas, especialmente aquelas que poderiam se reunir em torno da reorganizada Partisan Review, e o que exacerbou suas relações com os comunistas, foi sua disposição para abertamente combinar o marxismo com uma agressiva simpatia por temas e técnicas modernistas dos anos 1920, exemplificadas por T. S. Eliot. Em contraste, a atitude comunista oficial foi expressa por Mike Gold: 'Nos anos vinte, os jovens poetas seguiram T. S. Eliot. Eliot era para o período de boom da poesia o que Mencken fora para a prosa; ambos eram anti-povo, mentalidades fascistas, e ambos foram arrastados como pilares podres na enchente de novos critérios e novas demandas que a depressão trouxe para os escritores americanos.",121

$\mathrm{O}$ comentário de Mike Gold se filiava às idéias que foram divulgadas pelo Primeiro Congresso dos Escritores Soviéticos em 1934. Nele se propunha a doutrina do Realismo Socialista para as artes, que em essência realista se opunha à arte de vanguarda ocidental. ${ }^{122}$ Segundo Paul Wood, "compareceram (no Congresso) mais de seiscentos delegados, incluindo quarenta do exterior; e em 26 sessões foram feitas não menos que trezentas contribuições. E, ainda que ocorressem, os desacordos não foram significativos. As conclusões eram de que o Congresso apenas oficializara perspectivas que já haveriam sido decididas - como, de fato, haviam. Todos os grupos rivais, proletários e vanguardistas do mesmo modo, haviam sido dissolvidos e foi criada a única União dos Artistas - à qual os artistas que desejassem atuar na União Soviética deveriam aderir. Diz-se que a política (soviética para as artes) havia sido decidida em encontros secretos realizados no apartamento de Máximo Gorky em Moscou em

\footnotetext{
${ }^{121}$ WALD, A. M. The New York intellectuals: the rise and decline of the anti-stalinist left from the 1930s to the 1980s. North Carolina: The University of North Carolina Press, 1987, p. 94.

${ }^{122}$ Autores como Vittorio Strada, Katerina Clark e Paul Wood problematizaram a visão corrente sobre o Realismo Socialista. Para eles, não era possível entender o realismo socialista somente como uma doutrina de controle das artes, mas também como uma proposta mediada pelas condições históricas vividas pela URSS. Veja-se o comentário de Vittorio Strada: "Podemos tomar como ponto de partida aquele que foi o evento central da vida literária soviética: o Congresso dos Escritores de 1934, onde foi oficialmente consagrada a doutrina do 'realismo socialista'. O 'realismo socialista', nascido solenemente naquela reunião, que contou com a presença de dirigentes como Zdhanov e Bukharin e de escritores como Gorki e Fadeiev, é um fenômeno de indubitável complexidade política e cultural e deve ser analisado como tal, evitando-se as sumárias e irônic as polêmicas de que habitualmente tem sido alvo." STRADA, V. "Do 'realismo socialista' ao zdhanovismo" In História do marxismo: o marxismo na época da terceira internacional: problemas da cultura e da ideologia. (Org. Eric J. Hobsbawn). (vol. IX). Rio de Janeiro: Paz e Terra, 1987, p. 156. Paul Wood apresenta a hipótese de Katerine Clark: "O Realismo Socialista, na maioria das vezes, é visto pelos comentaristas ocidentais como uma camisa-de-força que impediu inexoravelmente a diversidade na arte por algum tempo. Entretanto, a situação talvez fosse mais complexa. Katerina Clark argumentou, persuasivamente, que a adoção do Realismo Socialista foi de alguma forma o reverso do período proletário que o precedeu. Ele foi criado, ela afirma, por aqueles que sentira $\mathrm{m}$ a necessidade de restabelecer a qualidade na arte, que estava sendo perigosamente ameaçada pela dinâmica agressiva do proletariado." WOOD, P. "Realismos e realidades" In BRIONY, FER et alii. Realismo, racionalismo, surrealismo: a arte no entre-guerras. São Paulo: Cosac \& Naify Edições, 1998, p. 320. (parênteses nossos).
} 
outubro de 1932, quando um grupo de políticos e intelectuais convidados discutiram um nome para o novo tipo de arte. Que essa arte seria 'realista' não estava em questão. Alguns, entretanto, queriam-na 'monumental'; outros, 'heróica'; e outros, ainda 'proletária'. Uma figura em particular, entretanto, continuava insistindo em que ela fosse 'socialista'. Essa figura era Stalin. E assim ficou 'Realismo Socialista'”. ${ }^{123}$

O movimento anti-stalinista de esquerda, formado em sua maioria por intelectuais e por artistas, tentava unir novamente vanguarda política e artística para recuperar o sentido original da revolução comunista. Daí, a aproximação com Trotski e a valorização da arte moderna, ambos condenados e banidos da URSS pelos stalinistas. Se o realismo em arte predominava nos anos trinta, ficava cada vez mais evidente que se carecia de uma alternativa para ele. O esgotamento estético do realismo era resultado tanto da perda de sua função conscientizadora quanto de sua grande eficácia como instrumento de propaganda governamental. No caso dos Estados Unidos, a arte realista de cunho nacional foi incentivada pelo governo e amplamente empregada pelos artistas que participaram dos programas da WPA-FAP. Ela estava direcionada para a exaltação dos ideais democráticos norte-americanos contra as ideologias estrangeiras e servia como instrumento de divulgação dos projetos e das realizações no governo Roosevelt para vencer a crise econômica e social que assolou o país.

Franklin D. Roosevelt tomou posse na Presidência dos Estados Unidos em 4 de março de 1933. Em sua carreira, ele já tinha governado Nova York, um dos estados em que a crise econômica foi mais acentuada, e ali o New Deal fora concebido. Tratava-se de um programa de governo ambicioso que pretendia atender tanto os capitalistas como os trabalhadores. Robert Sherwood aponta que, naqueles anos, Roosevelt modelara a atuação decisiva do Estado no campo social: “A 21 de agosto de 1931 o governador Roosevelt pronunciou (...): 'Que é o estado? É a representação devidamente constituída de uma sociedade organizada de seres humanos (...). O dever do estado para com os cidadãos é o dever do empregado para com o patrão. (...) Um dos deveres do estado é socorrer aqueles cidadãos que se virem vítimas de circunstâncias a tal ponto adversas que os deixem incapazes de satisfazer mesmo as mais simples necessidades sem amparo de outros. Dita responsabilidade é reconhecida por todas as nações civilizadas ... (...) A

${ }^{123}$ WOOD, P. Op. cit., pp. 323-324. (parênteses nossos). 
esses desafortunados cidadãos deve-se estender o amparo do governo, não como caridade, mas como uma face do dever social"”. 124

Roosevelt estava ciente de que se o Estado não interviesse para salvar o capitalismo e não minimizasse o abismo social, instalado no governo Hoover, talvez fosse muito provável uma alteração sem precedentes em todo o sistema econômico, social e político norte-americano. Sherwood, biógrafo da Casa Branca, comenta: "(Se o fascismo ascendia na Europa) bem mais imediata como ameaça era a suspeita, profundamente arraigada, de que a coisas poderiam acontecer aqui. Os dentes de dragão do fascismo e do comunismo, sementes do mal, espalhavam-se pelo mundo todo e naquele inverno de bancos a fechar, de vales em lugar de dinheiro, de filas intermináveis, era compreensível o temor de que aquelas sementes daninhas viessem a germinar e deitar raízes em solo americano." ${ }^{25}$ E Roosevelt discursou, mais tarde, sobre a índole democrática do povo norte-americano: "Se tempo houve em que foi posto à prova o vigor espiritual de nosso povo, esse tempo foi o da terrível depressão de 1929 e 1933. Nessa ocasião, o povo poderia ter-se voltado para ideologias estrangeiras, como o comunismo e o fascismo. (...) Todavia, nossa fé democrática foi suficientemente vigorosa. O que o povo americano pediu em 1933 não foi menos democracia, foi mais democracia - justamente o que recebeu." ${ }^{\text {126 }}$

De fato, o New Deal consistiu no patrocínio de programas de amparo aos desempregados, mas foi também e principalmente um programa de investimentos na área de infra-estrutura para refortalecer a economia capitalista. Robert Sherwood descreve o surgimento do WPA-FAP e seus resultados: “(Em fins de outubro de 1933), Roosevelt perguntou (a Hopkins) quantos empregos deveriam ser criados e (ele) respondeu que seriam da ordem de quatro milhões. (Roosevelt deu sinal positivo e o grupo de Hopkins elaborou os planos para execução do programa) que, em seus primeiros 30 dias de existência, empregou quatro milhões de pessoas e, em menos de quatro meses, deu início a 180 mil projetos e gastou mais de 933 milhões de dólares. Estavam lançadas as bases do que seria (...) a WPA e estabelecido o princípio do direito ao trabalho, que não poderia mais ser renegado. (A Administração de Obras Civis (CWA) que se tornou depois a WPA) era um programa caro e não poderia continuar muito tempo em sua escala original. (...) os resultados foram memoráveis. Incluíam: 40

\footnotetext{
${ }^{124}$ SHERWOOD, R. E. Roosevelt e Hopkins: uma história da Segunda Guerra Mundial. Rio de Janeiro: Nova Fronteira, 1998, pp. 46-47.

${ }^{125}$ SHERWOOD, R. E. Op. cit., p. 54. (parênteses nossos).

126 Idem, ibidem, p. 59.
} 
mil escolas construídas ou ampliadas; 3,5 milhões de metros de canos de esgotos instalados; 469 aeroportos construídos e 529 ampliados. (...) Entre as 4.264 .000 pessoas para as quais foram arranjados empregos havia três mil escritores e artistas; isso era o ponto de partida do Projeto de Arte Federal."127

Por causa do WPA-FAP, políticos da oposição acusaram Roosevelt de comunista. Para a maioria deles, o governo não deveria gastar dinheiro com programas sociais. No entanto, alguns membros da ala direitista confiavam no presidente. Sherwood diz: "Houve mesmo alguns empresários que observaram que o New Deal não era o que eles temiam: o prólogo do comunismo nos Estados Unidos. Tratava-se, de fato - como Roosevelt o concebera e o conduzira - de uma revolução política da direita, levantando-se para lutar em sua própria defesa. (...) (E Gerald W. Johnson comenta:) 'Quem tem dúvidas a respeito deveria atentar para o fito de que grupo algum sofre maior decepção com o Sr. Roosevelt do que os extremistas radicais. (...) O mais irritado membro do clube da Union League jamais lançou contra ele tantas ofensas quanto as empregadas constantemente pela imprensa comunista, até ficar evidente que Roosevelt não precisava deles, mas eles sim é que precisavam desesperadamente dele. A razão desse ódio dos radicais não é difícil de entender. Vem do fato de que aquele que esperavam fosse o liquidante do capitalismo, já que o apunhalara tão rudemente, talvez fosse, isto sim, um cirurgião de cujo bisturi o capitalismo emergisse, não morto, mas forte como nunca, dono de um novo sentido de vida. Os radicais talvez não estejam bem certos disso, mas seguramente temem que tal coisa aconteça e esse temor é evidentemente bem fundado ...,",128

O Projeto de Arte Federal foi criado porque se sabia que artistas, escritores e intelectuais tinham poder de influência sobre a opinião pública. No início dos anos trinta, muitos deles podiam ou tinham se aproximado ou do partido comunista ou de movimentos políticos de esquerda. Jonathan Harris expõe a natureza e os objetivos do FAP em atender os artistas plásticos: "Em 1933, o New Deal do governo de Roosevelt criou gigantescos programas de assistência social e esquemas de frentes de trabalho [...]. Entre esses programas de trabalho havia uma série de projetos concebidos para permitir que os artistas trabalhassem em troca de um salário padrão de 21 dólares por semana. No mais amplo deles, o FAP (1935-1943), os artistas se viram engajados coletivamente - contratados pelo Estado - como produtores para clientes do setor público (escolas,

\footnotetext{
127 SHERWOOD, R. E. Op. cit., pp. 68-69 e p. 74. (parênteses nossos).

${ }^{128}$ Idem, ibidem, pp. 91-92. (parênteses nossos).
} 
hospitais, prisões e outras instituições que desejassem receber obras de arte para expor). No geral, incentivavam os estilos 'naturalistas' e 'realistas', os quais predominaram, e a maioria dos artistas trabalhava em projetos para edifícios e locais públicos e não para galerias de arte ou museus." 129

Com exceção dos artistas nova-iorquinos, que desenvolveram uma série de experimentos formais modernos na Seção de Cavalete de Nova York, a maior parte dos artistas ligados ao FAP produziu naturalismo ou realismo social. Harris comenta: “[...] seria um equívoco afirmar que os trabalhos produzidos por Pollock, Rothko e outros foram 'típicos' da Arte Federal. [...] [Harris faz referência a obras públicas como o relevo escultural de Cesare Stea (1936), patrocinado pelo governo norte-americano, cuja temática são os trabalhadores do New Deal]. Esse trabalho compartilha elementos estilísticos e iconográficos da escultura realista socialista da União Soviética da mesma época, como O operário e a mulher da fazenda-modelo, obra de Vera Mukhina de 1937. Embora em escala consideravelmente menor, o relevo de Stea usa as convenções da 'monumentalidade' para transmitir a grandeza do 'trabalhador do Estado' como símbolo da missão da nação de reconstruir-se. Essa abstração simbólica, o 'trabalhador' personificado, foi um emblema ideológico chave na União Soviética e nos Estados Unidos da década de 30. Tanto o estado supostamente comunista (URSS) como o democrático (EUA) mobilizaram a retórica da transformação econômica e social em suas missões ideológicas oficiais - a suposta criação do socialismo na União Soviética e a reorganização do capitalismo em sistema democrático controlado e moralmente justificável nos Estados Unidos."

129 HARRIS, J. "Modernismo e cultura nos Estados Unidos, 1930-1960" In WOOD, P. et alii. Modernismo em disputa: a arte desde os anos quarenta. São Paulo: Cosac \& Naify Edições, 1998, p. 10.

${ }^{130}$ Idem, ibidem, pp. 12-13. (colchetes nossos). Segundo Harris não seria possível encontrar nas obras de arte norte-americanas da década de 1930, um estilo único ou um repertório estrito de temas comuns a todos os artistas: "Sucessivamente 'expressionistas', 'estilizadas' ou até 'cartunísticas', todas essas obras continham, entretanto, significados socialmente simbólicos e uma preocupação em representar suas imagens dos Estados Unidos da época da Depressão - seja a vida metropolitana nova-iorquina alienada, a crise na zona rural, ou o 'realismo democrático-capitalista' do (FAP) representando o cidadão-proletário estadunidense que conseguiu trabalho com o New Deal de Roosevelt.” Idem, ibidem, p. 13. (parênteses nossos). Sobre o grupo de artistas nova-iorquinos que iniciaram posteriormente as pesquisas do expressionismo abstrato, Harris esclarece que todos eles estavam envolvidos com política na década de 1930: "Juntamente com Rothko, Robert Motherwell e outros expressionistas abstratos, (Pollock) se envolveu com a política de esquerda como membro do Sindicato dos Artistas, fundado em 1934 para permitir aos artistas empregados pelo Estado negociar melhores condições e pressionar por períodos mais longos de trabalho nos projetos estatais (...). Além disso, artistas e críticos da esquerda envolveram-se em questões e debates políticos nacionais e internacionais, como a Frente popular contra o Fascismo, criada em 1935, e contra a Guerra Civil Espanhola, em 1936. Guernica, de Pablo Picasso, concluída em 1937, tornou-se ao mesmo tempo um símbolo da oposição ao bombardeio fascista da cidade espanhola e um símbolo da tentativa de fazer uma intervenção artística politicamente convincente que não se apoiava nas 
Harris aponta que os responsáveis pelo Projeto de Arte Federal incentivavam a produção de arte nacionalista. A partir de 1937, a arte norte-americana seria denominada Realismo Democrático pelos mentores e executores da FAP. O realismo, que servira antes para agitação e propaganda do comunismo e que estava agora a serviço da política de Roosevelt, era resultado da união dos valores democráticos dos Estados Unidos e da capacidade de atingir as massas em contraposição à arte européia. Harris elucida o vínculo que se estabeleceu entre arte e política no FAP: "O diretor do Projeto de Arte Federal, Holger Cahill, tornou explícita a relação entre a cultura e a democracia nos Estados Unidos na década de 30. Essa ligação era um elemento-chave na filosofia que orientava o projeto e, num discurso pronunciado na abertura de uma mostra de arte patrocinada pelo governo no Museu de Arte Moderna de Nova York em 1936, Cahill declarou que o projeto visava, em parte, minar as tradições acadêmicas importadas da Europa do século XIX bem como as recém-chegadas convenções da arte modernista. Nesse sentido, seu programa, baseado em questões culturais e políticas nacionais, diferia do programa dos artistas de esquerda, que, embora desejassem assistir a uma revolução socialista nos Estados Unidos, tinham também uma perspectiva internacionalista.",131

Para Cahill, o Realismo Democrático representava não menos os valores nacionais dos Estados Unidos que uma alternativa para o mundo, já que a arte européia era produto de uma civilização em crise. Harris diz: "Cahill atacava o Modernismo de vanguarda e também a arte acadêmica tradicional porque via em ambos importações essencialmente 'estrangeiras' de uma civilização européia ainda semifeudal que estava prestes a envolver a si e ao resto do mundo em mais uma guerra. (...) (Harris conclui:) essa forma de polêmica racista foi um componente do nacionalismo do New Deal que levou alguns administradores da arte governamental a atacar o predomínio da arte européia em geral nos Estados Unidos e que, por meio do Projeto de Arte Federal, cogitava uma intervenção do Estado na cultura nacional em prol da causa da conservação e da promoção de uma arte americana nativa. Tal arte deveria ser produzida por americanos para todo o povo americano; por isso as subvenções não objetivavam apenas deter o Modernismo americano e europeu, mas também democratizar radicalmente a experiência e a inteligibilidade de uma arte 'autêntica'

convenções do 'naturalismo' ou 'realismo social' então dominantes nos Estados Unidos.' Idem, ibidem, pp. 15-16. (parênteses nossos).

${ }^{131}$ HARRIS, J. Op. cit., p. 16. 
produzida por americanos. A existência e a influência de uma pequena mas influente Vanguarda Modernista - quase toda baseada em Nova York e patrocinada por uma intelligentsia exclusivista - era anátema para o populismo do Projeto de Arte Federal." 132

Encerrava-se a disputa sobre a Frente Popular e, por conseguinte, surgia uma alternativa para o Realismo Democrático nas artes plásticas. Muitos intelectuais e militantes decidiram se afastar do PCEUA não apenas por causa dos erros táticos que levaram os comunistas a apoiar o New Deal de Roosevelt e a tradição artística dos Estados Unidos, ${ }^{133}$ mas porque repercutiam as últimas notícias da URSS sobre a instalação dos Tribunais de Moscou. Foi assim que se consolidou o movimento norteamericano de esquerda cujo mote era o anti-stalinismo. Serge Guilbaut informa: "Depois do Primeiro Congresso de Artistas Americanos em 1936, a desaprovação da Frente Popular por uma parte dos intelectuais de esquerda tornou-se mais organizada e virulenta. O abismo entre trotskistas e stalinistas se ampliou (...). Não obstante as notícias sobre os Tribunais de Moscou, o Partido Comunista continuou a dar sustentação para a Rússia stalinista. Isso, e o pacto Russo-Germânico, levou um crescente número de intelectuais desiludidos para a oposição, porque eles não podiam sustentar a postura não crítica do Partido. Para muitos intelectuais, ficava cada vez mais claro que era necessário independência de todos os partidos políticos para os artistas e escritores." 134

\footnotetext{
${ }^{132}$ HARRIS, J. Op. cit., pp. 17-18. (parênteses nossos).

${ }^{133}$ Em 1937, ocorreu o estreitamento conjuntural da aliança entre o Partido Comunista e a política do New Deal. Comenta Seaton: "O (PCEUA) começou a manifestar mais abertamente apoio a Roosevelt em fevereiro de 1937, depois da solicitação do presidente para que o Congresso desse a ele a autoridade para forçar a retirada de juízes da Suprema Corte (...). Não obstante o fracasso desse esquema de engessar a corte, (...) os comunistas viram isso como um sinal do compromisso de Roosevelt em resistir aos conservadores. (...) A Décima Convenção do Partido Comunista dos Estados Unidos, ocorrida em Nova York em 26 de maio, modificou a política da Frente Popular para incluir o apoio oficial de Roosevelt e do New Deal. Em seu informe na conferência de 28 de maio, Browder alinhou a Frente Popular com a "ala New Deal do Partido Democrático" (...). Clarence Hathaway, editora do Daily Worker, deu a essa coalizão um novo nome americanizado, a "Frente Democrática"'. SEATON, E. G. Federal prints and democratic culture: the graphic arts division of the Works Progress Administration Federal Art Project, 1935-1943. Tese de Doutorado. Northwestern University, Illinois, 2000, p. 157. (parênteses nossos).

${ }^{134}$ GUILBAUT, S. How New York stole the idea of the modern art - abstract expressionism, freedom, and the cold war. Chicago: The University of Chicago Press, 1985, p. 21.
} 


\section{Apelo trotskista: o Manifesto por uma arte revolucionária e independente}

Com o exílio em 1937, Mário Pedrosa iniciou atividade intensa como militante ligado à IV Internacional. Sua ida à Europa ocorreu em condições pouco favoráveis, já que ele fugia às pressas do Brasil. Tendo a prisão decretada, seu amigo Nelson Chaves emprestou-lhe o passaporte. A ameaça iminente de ser preso pela polícia de Getúlio Vargas e a impossibilidade de adiar a viagem fizeram com que Pedrosa embarcasse em um navio controlado pelos nazistas em direção à França. Naquela ocasião, ele não descartava a possibilidade de ser identificado e de ser alvo de um pedido de extradição ditado pelo governo brasileiro. Consciente do perigo que corria, tratou de levar consigo um livro de Goethe, que deixava todas as manhãs sobre a cômoda antes da chegada dos funcionários encarregados de inspecionar as cabines. Chegou a Paris e encontrou Pierre Naville. Esse último entrou em contato com Trotski e indicou Pedrosa para trabalhar como secretário da seção trotskista francesa e para colaborar nos trabalhos de fundação da IV Internacional. ${ }^{135}$

A tentativa de fundação da IV Internacional esbarrava em dificuldades impostas pelo cenário político na Europa e no mundo. Daí, a insistência de alguns militantes em não proclamar sua fundação. Havia motivos fortes para isso: os trotskistas não tinham suporte relevante das camadas proletárias; a 'Oposição de Esquerda' na URSS, a mais numerosa entre todas, tinha sido dizimada nos campos de trabalho forçado ou nos fuzilamentos coletivos; o crescimento vertiginoso da ameaça fascista e a irrupção

\footnotetext{
135 Cf. HOUSTON, M. "Cronologia” In Mário Pedrosa: arte, revolução, reflexão. Centro Cultural Banco do Brasil, Porto Alegre, 06-07-1992, pp. 56-57. Por causa da perseguição da GPU aos militantes trotskistas e do perigo de receptação de documentos sobre a fundação da IV Internacional, Pedrosa passou a utilizar o pseudônimo "Lebrun". Mary Houston relata a trajetória de Mário Pedrosa: "Em 1935, [Pedrosa] transfere-se para o Rio de Janeiro e passa a trabalhar na Agência Havas. Ajuda clandestinamente a Aliança Nacional libertadora e se liga a certos elementos do PCB, como Barreto Leite, que escreve a famosa carta a Prestes criticando a ANL. [...] Com o golpe [comunista] deste ano (com o qual não tinha qualquer envolvimento), passa a ser procurado intensamente pela polícia [...]. [Em 1936], Mário monta, clandestinamente, um prelo para publicar a Luta de classe, e lança, em nome da LCI [Liga Comunista Internacionalista] e da ala esquerda do PCB, liderada por Hermínio Sacheta, a candidatura simbólica de Luís Carlos Prestes, que se encontrava na prisão, à presidência da República. [Em 1937], escreve um ensaio de análise econômica e política da situação brasileira que circulou apenas em versão mimeografada. [...] Vem o golpe de estado de 10 de novembro e recomeçam as perseguições políticas. Mário é processado e foge para Paris utilizando o passaporte de um amigo." Idem, ibidem, pp. 56-57. (colchetes nossos).
} 
iminente da guerra compunham um quadro conjuntural nada animador. Mesmo assim, Trotski insistiu na necessidade de fundar a IV Internacional. O curso dos acontecimentos veio mostrar a fraqueza da nova organização, pois a despeito dos esforços de seus militantes, a Internacional não contava com uma base tão numerosa e uma estrutura organizada como a que os partidos comunistas possuíam. Na França, sua importância seria abafada pela guerra e pela atividade criminosa dos stalinistas e, finalmente, nos Estados Unidos, onde sua atuação foi conturbada por causa da luta entre as frações trotskistas, ela não conseguiu se aproximar da classe trabalhadora cooptada pelo PCEUA e pelo governo de Franklin D. Roosevelt.

Depois da crise no campo e da baixa brutal da produção de alimentos que trouxe fome para a URSS em 1933, iniciava-se uma nova fase de tensão dentro da cúpula dirigente. A eliminação das forças oposicionistas significava a perpetuação do regime stalinista diante de tamanha crise. Esse processo de caça às oposições foi além dos limites do território russo e se intensificou na ação da GPU nos países europeus. Foi assim que Rudolf Klement foi assassinado. Companheiro jovem de Mário Pedrosa no Secretariado Internacional, Klement levou consigo a mensagem da morte próxima de Trotski. Além de alguns papéis sobre a situação dos grupos trotskistas em vários países e poucas atas para a realização do Congresso de Fundação da IV Internacional, os agentes da GPU não encontraram nada mais com ele. Sem dúvida, sua morte foi um símbolo da eliminação definitiva das atividades de oposição trotskista na Europa, tal como havia sido a morte de Leon Sedov (Liova), além de ser também nesse caso um ataque pessoal a Trotski. Apesar de todas as pressões contra a realização do congresso, seus preparativos continuaram em ritmo acelerado.

Para evitar novas ações terroristas ficou decidido que o Congresso de Fundação da IV Internacional se realizaria na casa de Alfred Rosmer em Périgny, local pouco movimentado nas imediações de Paris. Ali, em 3 de setembro de 1938, o Congresso foi realizado em uma sessão ininterrupta e sem a presença de observadores, para evitar outros atentados. A participação foi restrita aos membros mais estreitamente ligados às posições de Trotski, sendo que Pedrosa participou dessa reunião representando as sessões da América Latina e, dado o peso da organização trotskista norte-americana, que contava naquela época com cerca de dois mil membros, o seu representante Max Shachtman presidiu a conferência. Issac Deutscher expõe o acontecimento: "Estavam presentes 21 delegados, pretendendo representar as organizações de onze países. A conferência foi instalada ainda sob o impacto dos recentes assassinatos e raptos. Elegeu 
três jovens mártires, Liova, Klement e Erwin Wilf, como seus presidentes honorários. (Apesar da objeção da seção polonesa) (...) na votação, a conferência resolveu, pela maioria de 19 contra 3, proclamar a Quarta Internacional naquele momento. (...) (E Deutscher conclui:) Trotski resolveu 'fundar' a nova Internacional numa época em que, como os poloneses advertiram, tal medida não poderia provocar nenhum impacto."136

Trotski enviou uma carta, em 1 de junho de 1938, para os membros do Congresso de Fundação da IV Internacional. Nela, ele expunha os motivos para a fundação de uma nova Internacional, que se opusesse tanto à organização social democrata como à III Internacional e que recuperasse as bandeiras da revolução proletária e do internacionalismo: "Em todo o curso de sua história, o proletariado nunca foi tão enganado e traído por suas organizações como é hoje, vinte e cinco anos depois do início da Primeira Guerra Mundial e alguns anos ou quiçá apenas meses antes do início da Segunda (...). A internacional socialdemocrata, como foi ilustrada pela última e mais recente experiência governamental de Leon Blum em França, é uma auxiliar do aparato do estado burguês, que a convoca para que o ajude durante os períodos mais difíceis e para o mais vergonhoso trabalho: em particular, preparar uma nova guerra imperialista. O papel da Terceira Internacional é ainda mais criminoso e daninho - se tal coisa é possível - porque encobre os serviços que presta ao imperialismo, com a autoridade roubada da Revolução de Outubro e do bolchevismo. Sobre o solo da Espanha, o stalinismo demonstrou, com evidente clareza, que assumiu o papel de gendarme internacional contra a revolução proletária, o mesmo papel que jogou o Czarismo contra a revolução burguesa." 137

Ademais Trotski trazia, com aquela carta, o debate sobre o significado e o estado atual das artes para a pauta do Congresso de Fundação. Não se tratava de uma paixão irremissível. Foi necessidade não somente de se posicionar sobre os últimos acontecimentos que ocorriam na URSS e no mundo, mas também de abrir interlocução com intelectuais, escritores e artistas norte-americanos. Ainda que Trotski estivesse interessado prioritariamente em fundar a nova Internacional como órgão difusor da doutrina bolchevique junto ao proletariado, não era mais possível pensar no sucesso dessa empreitada sem contar com apoio de parte da intelectualidade simpatizante e

\footnotetext{
${ }^{136}$ DEUTSCHER, I. Trotski: o profeta banido. Rio de Janeiro: Editora Civilização Brasileira, 1984, pp. 432-435.

${ }^{137}$ TROTSKI, L. "El arte revolucionario y la Cuarta Internacional" In Litterature et Revolution, editado por Maurice Nadeau (1964). Disponível em: 〈http://www.ceip.org.ar/escritos/libro5/html/T09V238.htm>. Acesso em: 28 de fevereiro de 2002. Carta aberta aos membros do Congresso de Fundação da IV Internacional.
} 
difusora da causa comunista. De certa forma - e apesar de possuírem objetivos muito diversos - isso também ocorria com o regime stalinista, pois o respaldo que a URSS adquiria internacionalmente nos meios intelectuais da Europa e também nos Estados Unidos servia para a sustentação do regime. Se para Stálin a influência e a notoriedade do regime soviético capitalizavam adeptos em todas as partes, para Trotski a aproximação com os intelectuais dava-se tanto pelo esforço de formação de uma opinião crítica majoritária a favor da tese internacionalista da revolução comunista, e consequentemente da renovação do regime na URSS, como pela necessidade de afirmação da essência revolucionária da arte.

A carta de Trotski continha um esboço das linhas principais de um artigo mais extenso sobre a relação entre o Estado soviético e as artes, publicado duas semanas depois na revista norte-americana Partisan Review. ${ }^{138}$ Nesse artigo, Trotski esclarecia com mais detalhes sua compreensão do fenômeno artístico e indicava o impasse principal vivido pela arte em seu tempo. Não havia qualquer tentativa de sobrestimar a possibilidade de intervenção ativa da arte sobre a realidade. Trotski avaliava a realização das potencialidades da arte em conjunto com a transformação política e social. Ainda que suas proposições fossem generosas no que concerne ao futuro, o destino atual da arte estava condicionado à realização ou não de uma nova sociedade. Ele diz: "De modo geral, o homem expressa na arte a sua exigência da harmonia e da plenitude da existência - quer dizer, do bem supremo do qual é justamente a sociedade de classes que o priva." ${ }^{\text {"139 }}$ Essa seria a relação fundamental entre a arte e seu tempo. O que significava dizer que, fora desse horizonte histórico, a arte não poderia atuar.

Restringida por regras na URSS e instrumentalizada em vários países, a arte tinha um futuro incerto. Ainda que ela colaborasse para a transformação estética da

\footnotetext{
138 Artigo publicado na Partisan Review em 17 de junho de 1938, sob o título "A arte e a revolução" In BRETON, A. \& TROTSKI, L. Por uma arte revolucionária independente. São Paulo: Paz e Terra: CEMAP, 1985, pp. 91-100. Segundo Trotski, a própria escolha do estilo da carta indicava que havia coesão entre a forma e o conteúdo. Esse realismo narrativo era expressão das novas condições históricas e de uma necessidade interior da linguagem artística. Por sua vez, esta estava marcada pelo anseio da mudança completa das condições sociais em que se inseria. A perspectiva histórica utilizada por Trotski inclui, sem exceção, a participação de todas as atividades humanas e o estudo apurado dos vínculos entre arte e política: "Permita-me, porém, lançar um relance sobre a missão histórica da Quarta Internacional, não só com os olhos de um proletário revolucionário senão também com os olhos do artista de profissão que sou. Nunca separei estes dois campos de minha atividade. Minha caneta nunca me serviu como brinquedo de diversão pessoal ou para as classes dominantes. Sempre me esforcei por expressar os sofrimentos, esperanças e lutas das classes trabalhadoras, porque é assim que me aproximo da vida e portanto da arte, a qual é parte inseparável desta." TROTSKI, L. "El arte revolucionario y la Cuarta Internacional" In Litterature et Revolution, editado por Maurice Nadeau (1964). Disponível em: <http://www.ceip.org.ar/escritos/libro5/html/T09V238.htm>. Acesso em: 28 de fevereiro de 2002.

139 TROTSKI, L. "A arte e a revolução" In BRETON, A. \& TROTSKI, L. Por uma arte revolucionária independente. São Paulo: Paz e Terra: CEMAP, 1985, p. 91.
} 
realidade, todo seu esforço de formação de uma nova sensibilidade poderia não convergir para a emancipação final do homem. Afinal, perguntava Trotski, o que evitaria que a arte permanecesse condenada nos dias atuais assim como "a arte grega pereceu sob as ruínas da sociedade escravista" ${ }^{140}$ A alternativa desse impasse não se resolveria por conta única e exclusiva da arte. Naquele período, em que o condicionamento artístico evidenciava os desígnios da sociedade de classes ou da burocracia stalinista, parecia não restar horizontes amplos de criação. Entretanto, Trotski viu aquilo que poucos ousaram ver, um espírito comum que na luta pela transformação social permearia a vida intelectual e artística: "A inevitável crise atual do capitalismo implica uma crise de toda a cultura humana, incluindo a arte. (...) De certa forma, a situação geral do mundo obstaculiza o caminho revolucionário da criatividade, aos artistas talentosos e sensitivos. Este caminho desgraçadamente está obstruído pelos fétidos cadáveres do reformismo e do stalinismo. Se a vanguarda do proletariado mundial encontra sua direção, a arte de vanguarda encontrará novas perspectivas e uma nova esperança. Entretanto a chamada Internacional Comunista, que não concede ao proletariado mais que derrotas e humilhações, continua dirigindo a vida intelectual e a atividade artística da ala esquerda da intelectualidade internacional." ${ }^{141}$

Trotski afirmava que o impulso contestador da arte não se subordinava às regras burocráticas, às fórmulas prontas e aos esquemas estabelecidos. Para ele, a arte em sua essência se opunha à realidade falseada ou apresentava um mundo que ainda não estava realizado. ${ }^{142} \mathrm{~A}$ arte era avessa ao dirigismo cultural e lutava tanto contra a mistificação da realidade quanto contra a legitimação de um poder tirânico e desumano. Em oposição a esse estado de coisas, Trotski pretendia indicar uma nova relação entre arte e política: "A Quarta Internacional, obviamente, não pode assumir a tarefa de dirigir a arte, quer dizer, dar ordens ou prescrever métodos. Tal atitude para com a arte só pode caber nas

\footnotetext{
${ }^{140}$ Além do doutrinarismo e da instrumentalização nas artes, Trotski aponta o problema da assimilação da mensagem artística revolucionária pelo capitalismo: “A força da sociedade burguesa foi, durante longos períodos históricos, mostrar-se capaz de disciplinar todo movimento 'subversivo' em arte e levá-lo até o 'reconhecimento' oficial, combinando pressões e exortações, boicotes e adulações. Mas, tal reconhecimento significava no fim das contas a chegada da agonia. Então, da ala esquerda da es cola legalizada ou da base, das fileiras da nova geração da boêmia artística, levantavam-se novas correntes subversivas que, após algum tempo, subiam por sua vez os degraus da academia.” TROTSKI, L. Op. cit., p. 91.

${ }^{141}$ TROTSKI, L. "El arte revolucionario y la Cuarta Internacional" In Litterature et Revolution, editado por Maurice Nadeau (1964). Disponível em: <http://www.ceip.org.ar/escritos/libro5/html/T09V238.htm>. Acesso em: 28 de fevereiro de 2002.

${ }^{142}$ Trotski dizia que em essência a arte era contestadora. Por isso, ela não poderia sobreviver em um regime totalitário: "a criação intelectual é incompatível com a mentira, a falsificação e o oportunismo". TROTSKI, L. "A arte e a revolução" In BRETON, A. \& TROTSKI, L. Por uma arte revolucionária independente. São Paulo: Paz e Terra: CEMAP, 1985, p. 99.
} 
mentes dos burocratas de Moscou, embriagados de onipotência. A arte e a ciência não encontram sua essência fundamental através de modelos; a arte, por sua própria natureza, os rechaça. (...) Os resultados desta hegemonia são particularmente notáveis na URSS, onde a atividade criativa revolucionária havia alcançado seu alto desenvolvimento. A ditadura da burocracia reacionária asfixiou e prostituiu a atividade intelectual de toda uma geração. É impossível observar sem repugnância física as reproduções de pinturas e esculturas soviéticas, nas quais funcionários armados de pincéis, sob a vigilância de funcionários armados de rifles, glorificam a seus chefes como 'grandes' homens e 'gênios"”,143.

A tarefa da IV Internacional consistia em oferecer uma nova perspectiva revolucionária para o proletariado. Mas, não era apenas isso. Seu esforço visava criar uma alternativa para o mundo. Essa era sua tarefa principal, sem a qual, a arte estaria também condenada. A conclusão de Trotski não deixava dúvida para os intelectuais e para os artistas sobre qual posicionamento eles poderiam ter sobre a revolução comunista e sobre a URSS. Mas, não foi exatamente isso que aconteceu, pois a solidariedade com os comunistas stalinistas crescia na Europa e no mundo, sobretudo depois das vitórias da Frente Popular na Espanha. O agravamento das relações sociais nas sociedades burguesas, nos anos trinta, e a crescente notoriedade do regime soviético levaram muitos intelectuais, escritores e artistas a se voltarem para a causa comunista. Isso em si não deixava de ser desejável, pois no entender de Trotski, revolução e arte andavam juntas. Porém, o que ele se perguntava é: a que custo se fazia isso? Já que era imprescindível separar as duas forças existentes e em tensão no regime soviético: de um lado, o proletariado e, de outro, a burocracia dirigente ${ }^{144}$.

\footnotetext{
${ }^{143}$ TROTSKI, L. "El arte revolucionario y la Cuarta Internacional" In Litterature et Revolution, editado por Maurice Nadeau (1964). Disponível em: <http://www.ceip.org.ar/escritos/libro5/html/T09V238.htm>. Acesso em: 28 de fevereiro de 2002. Sob o efeito devastador de sua crítica ao regime socialista da URSS, a única alternativa da burocracia foi proibir e censurar a expressão franca da arte. No caso do potencial revolucionário da arte na URSS, ela contestou ali a realização da liberdade e do socialismo. Era como se o contexto histórico permitisse essa via de mão dupla para a arte: de um lado, ela mantinha-se como expressão viva das condições reais de transformação da realidade, de substituição da visão de mundo estabelecida, de outro lado, ela não podia manifestar a realização plena de suas potencialidades sem a transformação efetiva das velhas condições.

${ }^{144}$ Trotski diria no Manifesto por uma arte revolucionária independente: "Mas sob esse aspecto, justamente, a História armou aos artistas uma grandiosa cilada. Toda uma geração de intelectuais 'de esquerda', no decurso dos dez ou quinze últimos anos, voltou-se para o Leste, e em graus diversos, ligou seu destino, senão ao do proletariado revolucionário, pelo menos à revolução triunfante. Mas não é a mesma coisa. Na revolução triunfante não há somente a revolução, mas também a nova camada privilegiada que subiu às suas custas. Na realidade, os intelectuais 'de esquerda' mudaram de senhor." BRETON, A. \& TROTSKI, L. Por uma arte revolucionária independente. São Paulo: Paz e Terra: CEMAP, 1985, p. 92. Trotski referia -se aqui às personalidades proeminentes da cultura européia que se tinham direcionado para a defesa do stalinismo, tais como André Malraux, Romain Rolland, etc.
} 
Na década de 1930, ocorreu em toda parte aquele mesmo processo intenso de debate sobre os impasses da sociedade moderna, que levava de roldão as discussões e contribuições artísticas. O desenvolvimento do fascismo - como foi dito - urgia atitudes emergenciais. Esse parecia ser um momento de descompasso entre a produção artística analítica das vanguardas artísticas, que guardava a essência de uma pesquisa pura sobre as relações intrínsecas do material, e um chamado à realidade em forma de combate político. Por um lado, a crise social profunda que enredava a Europa e o mundo era uma das causas do chamamento de muitos dos principais artistas para o trato direto com as questões da política e para uma tomada de posição política efetiva. Por outro, a posição de destaque internacional conquistada pela URSS facilitava a penetração e influência de suas idéias na intelectualidade européia, que por sua vez acreditava no comunismo como bandeira de salvação contra o fascismo.

A opção pela URSS stalinista transformava-se em uma verdadeira armadilha para aqueles que se dispunham a abrir mão de suas pesquisas e conquistas no campo das artes em troca da vitória definitiva do socialismo. A solução de continuidade e a descrição dessa turba de ações desencontradas, que paralisavam a descoberta artística e incentivavam uma volta à arte mais convencional, foi esboçada por Trotski em seu livro “A Revolução Traída". Para ele, não se tratava de apostar, como um último recurso, a própria alma no regime soviético para combater o fascismo e sua pretensa união das classes em favor de um desenvolvimento nacional. Desde o final da década de vinte, Trotski alertava que a URSS não era uma alternativa viável para o interesse internacionalista da revolução e que, se não houvesse mudanças, o desenvolvimento da arte estava ali comprometido. Por isso, os artistas encontravam-se à mercê de seu próprio engano e mais ainda os artistas modernos que fizeram a escolha por uma doutrina política e por um regime que não aceitava em hipótese alguma suas produções artísticas.

Nesse cenário sufocante e sem sinal de qualquer garantia para uma concordância satisfatória entre o processo revolucionário e a arte de vanguarda, a posição de Trotski surgia irrefutável como mais um, entre poucos, oásis seguro. Sua argumentação condenava a posição stalinista e mostrava como muito da intelectualidade e dos artistas foram levados pela proposta ética do regime soviético, que encoberta pela idéia de construção do socialismo, negava a liberdade de manifestação artística para somente no futuro garanti-la em todo seu significado. Para Trotski, a condução dos assuntos relacionados à cultura, e por pressuposto às artes, 
seguia de forma geral a mesma falta de visão que comprometia irremediavelmente as conquistas sociais do período revolucionário do regime, a ponto de invalidá-las. Em suma, a ética da formação de um homem de senso livre e coletivo foi substituída pela justificação de toda sorte de repressão à criatividade e ao pensamento.

Todos os avanços apontados por Trotski no período inicial da revolução e que conduziam ao semblante de uma nova sociedade, não tiveram prosseguimento ou qualquer solução satisfatória. A ética para a qual vários artistas e intelectuais europeus de vanguarda se dirigiam com espontaneidade, quando defendiam o regime soviético, era no fundo a ética dos meios que justificavam os fins. Esse alerta de Trotski servia para mostrar bem de que maneira era lícito tomar frente na luta contra o fascismo e, ao mesmo tempo, em favor de uma revolução internacional que renovasse o regime soviético, em termos muito mais generosos. Seu enfoque foi voltado para a crítica das forças vitoriosas no regime e para uma elucidação clara das deficiências próprias da natureza circunstancial e do lugar ocupado pela Rússia no cenário internacional de desenvolvimento do capitalismo moderno. Portanto, dois registros, o político e o econômico, pressionavam a formação de uma cultura tolhida. ${ }^{145}$

Em “A Revolução Traída” de 1937, Trotski já mostrava até que ponto a arte fora levada para o campo das atividades administradas pelo Estado soviético. Esse processo de intervenção nas artes e na cultura em geral iniciava-se como parte da dominação ideológica investida contra as massas. Seus principais motivos eram a força das condições concretas de desenvolvimento da revolução na URSS e, ao mesmo tempo, a tentativa de preservação do poder político pela burocracia. Daí resultava uma atividade

\footnotetext{
${ }^{145}$ Não existia uma solução de continuidade para a crise social e para a nova dimensão ética forjada pela arte moderna quer nos termos exclusivos de uma compreensão pura do desenvolvimento nacional, quer no desenvolvimento do socialismo em um só país. Por isso, era necessária uma renovação do regime para que fosse possível modificar os contornos de sua política cultural. A alternativa ética dava-se como parte das ações de transformação social mundial e não tinha precedência em relação ao princípio revolucionário na política, mas deveria ocorrer em concomitância com ele. Isso explica a posição de Trotski sobre as origens sociais do desmantelamento cultural dos soviets e de todas as experiências de vanguarda artística durante o período stalinista, que tinham sua fonte na própria formação histórico-econômica da Rússia. Nesse contexto de pressão das necessidades e de estado crônico de penúria, a política dirigiu todas as atividades sociais para o desenvolvimento econômico acelerado do país. Perdia-se de vista o des tino civilizatório da construção da sociedade em direção ao socialismo. A única alternativa possível para a recuperação dos próprios ideais revolucionários e para a liberdade da arte era a volta à tese internacionalista. Com ela, poder-se-ia eliminar o dilema central da concorrência do regime soviético com os países mais avançados do capitalismo. Se se imaginava que uma revolução em escala mundial seria conseguida em pouco tempo, devido às condições históricas propícias, e através da mobilização dos trabalhadores, por seu turno, as artes não serviriam como instrumento de cooptação da intelectualidade, mas seu desenvolvimento era parte fundamental da própria transformação apregoada pela revolução. Ela fazia parte do imenso esforço destinado à formação de um novo modo de vida, de um novo sentido de coletividade e da liberação completa do homem para sua realização e a realização de seu destino. Cf. MARCUSE, H. Le marxisme soviétique. Paris: Éditions Gallimard, 1963, pp. 177 e seguintes.
} 
estatal de sinais trocados para os valores da cultura na sociedade soviética, com a anunciação da sociedade socialista realizada e com a aproximação dos mesmos valores da civilização burguesa ocidental. Para Trotski, essa inversão desconsiderava que a cultura e a arte nutriam-se das relações sociais e que a solução dos problemas econômicos mais elementares na URSS "não (significava) todavia a vitória do socialismo como novo princípio histórico."146 Assim, a máxima da "transformação dos homens" era utilizada pela burocracia stalinista para dar a impressão de que o regime socialista estava consolidado.

A burocracia stalinista justificava as modificações implementadas pelo regime como o único caminho possível para a construção do socialismo. Essa alternativa, ao mesmo tempo política e econômica, levava consigo o domínio das artes. O retrocesso cultural que atingia a URSS era parte da necessidade da burocracia de fundar uma hierarquia social definida e estável que reificasse as relações sociais de poder e de subordinação. Com o antagonismo entre o discurso e a prática, estabelecia-se um padrão ético coletivo baseado no cinismo e na hipocrisia dos meios dirigentes. Acrescia-se a isso o interesse em restabelecer e aprofundar a semelhança com as condições gerais reinantes nas sociedades ocidentais. Por causa da direção tomada pelo regime soviético sob o comando de Stálin, Trotski concluiu que ocorrera uma inversão dos valores do socialismo: "Nenhuma geração pode saltar por sobre sua própria cabeça. Todo o movimento Stakhanov está fundado nesse momento no 'egoísmo baixo'. Seu único padrão de medida, que é o número de calças e gravatas adquiridos pelo trabalho, confirma a 'mesquinhez pequeno-burguesa'."147.

Trotski dizia que as revoluções burguesas foram fundamentais no desenvolvimento político e cultural do Ocidente, mas na Rússia, sob as condições históricas de crise do capitalismo, esse processo foi interrompido e levou à rota do socialismo. Daí surgiu a base das principais contradições tanto no domínio da economia como no da cultura. O outro lado da moeda na revolução russa foi o que Trotski descreveu como a "miséria socializada". Ao mesmo tempo em que se reabilitava a família, a proibição do aborto e a permissão dos cultos religiosos, a relação monetária triunfava pela insuficiência material e cultural do Estado. Conclui Trotski: "Em vez de dizer: Encontramo-nos demasiado indigentes e demasiado incultos para estabelecer

\footnotetext{
146 TROTSKI, L. La revolucion traicionada. Buenos Aires: El Yunque Editora, 1973, p. 179. (parênteses nossos).

${ }^{147}$ Idem, ibidem, pp. 168-169.
} 
relações socialistas entre os homens, nossos filhos ou netos o farão, os chefes do regime recompõem as inutilidades rotas da família e impõem, sob rigorosas ameaças, o dogma da família, fundamento sagrado do socialismo triunfante."148 Acentuava-se a tendência medíocre e conservadora nos meios dirigentes de se perpetuarem no poder e dava-se respaldo à ética da conquista individualista e da vantagem pessoal na aquisição de conforto e de bem-estar.

Trotski concluía que a sociedade soviética assumiu "um caráter mais ou menos pequeno-burguês na economia, na família e na poesia". ${ }^{149}$ É justamente por causa dessa diferença de análise sobre a URSS que foi possível a Trotski acenar para outra experiência artística. Ela encontrava-se na posição oposta ao modelo defendido pelo regime stalinista, que balizava o dirigismo cultural como referência única e designação de valor. O stalinismo queria uma arte que servisse de propaganda das conquistas do regime soviético. Daí chegava-se, ao invés da conclusão sobre a determinação ou autonomia relativa da arte, à proposição de seu caráter instrumental e, por consequiência, passível de orientação externa, extra-artística. O dirigismo cultural ou a instrumentalização da arte passava m a ser o modo de expressão consciente dos limites condicionais e intencionais da mensagem artística. Sendo assim, a arte transpunha o campo de construção de uma nova sensibilidade para a simples apresentação fantasiada do mundo, segundo normas e critérios estabelecidos pela direção política da URSS. Ocorria a passagem rápida e drástica da perspectiva de tomada de consciência dos artistas do problema central da sociedade moderna, que se resumia na luta de classes,

\footnotetext{
${ }^{148}$ TROTSKI, L. Op. cit., p. 159. O intuito do pensamento de Trotski, com relação à cultura e às artes e, por extensão, ao problema fundamental delas em nossa época, era fornecer um novo parâmetro para sua produção e reafirmar o compromisso da arte com a mudança social através de sua essência libertadora. A identidade da arte com os valores em construção do novo homem adviria da ruptura com as condições econômicas e políticas responsáveis por sua escravização em todas as partes. Nessa via, seria impensável supor que a posição devida à arte na nova sociedade fosse dispensável e condicionada a fatores utilitários ou apenas à estratégia política. Para Trotski, a fase inicial da revolução abrira, com suas medidas inauditas até aquele momento, uma nova concepção para se pensar toda a contribuição humana em favor de sua própria libertação. Assim, a arte ocupava a mesma posição de importância que a mulher teria na nova sociedade. Comenta Trotski: "A Revolução de Outubro manteve com honradez sua palavra com respeito à mulher. $\mathrm{O}$ novo poder não se contentou em dar à mulher os mesmos direitos jurídicos $\mathrm{e}$ políticos que ao homem, senão que, mais ainda, fez tudo o que podia e mais que qualquer outro regime para abrir-lhe realmente o acesso a todas as conquistas econômicas e culturais. (...) A revolução intentou heroicamente destruir o antigo 'lar familiar' podre, instituição arcaica, rotineira e esmagadora na qual a mulher das classes trabalhadoras está condenada a trabalhos forçados desde a infância até a velhice. À família, considerada como uma pequena empresa fechada, devia sucedê-la, segundo a intenção dos revolucionários, um sistema acabado de serviços sociais: maternidades, berçários, jardins de infância, restaurantes, lavanderias, dispensários, hospitais, (...), cinemas, teatros, etc. A absorção completa das funções econômicas da família pela sociedade socialista, ligando toda uma geração pela solidariedade e pela assistência mútua, devia trazer para a mulher, e por fim ao casal, uma verdadeira emancipação do jugo secular" Idem, ibidem, pp. 153-154.

${ }^{149}$ Cf. Idem, ibidem, pp. 159-160.
} 
para um estágio de defesa a todo custo das conquistas da revolução e de sua institucionalização.

Mais e mais, a França tornava-se um lugar instável e perigoso para a continuidade dos trabalhos da IV Internacional. Trotski então aconselhou os membros do Secretariado Internacional a transferirem sua sede e os arquivos para os Estados Unidos. Mário Pedrosa viajou para lá e passou a residir em Nova York no final de 1938. Ali, Pedrosa travou contato permanente com militantes trotskistas norteamericanos, entre os quais os mais conhecidos eram James Burnham, Max Shachtman e James P. Cannon, e com muitos artistas, literatos e críticos de arte que se aproximaram do trotskismo, tais como Clement Greenberg e Meyer Schapiro. No que concerne à mudança do Secretariado Internacional, ela não vis ava apenas preservá-lo, mas era estratégica do ponto de vista internacionalista de Trotski para a formação de uma base substancial de apoio da classe trabalhadora norte-americana à causa revolucionária . Trotski entendia que a nova etapa de organização da classe operária poderia surgir nos Estados Unidos e dali reconquistar a Europa e entrar de maneira triunfal na própria URSS. Também, segundo sua avaliação, o surgimento de um levante contra o capitalismo se daria no Ocidente sob a escolha, ou do modelo soviético, ou do restabelecimento de novas bases para a revolução sob influência da nova Internacional. Pedrosa e os militantes norte-americanos foram incumbidos de difundir as propostas da Internacional nas Américas.

Isaac Deutscher comenta a influência das idéias de Trotski sobre intelectuais, escritores e artistas norte-americanos: "Entre a intelectualidade americana radical, especialmente nos meios literários, o trotskismo fazia progresso, nessa época. Sob o impacto da grande depressão, da ascensão do nazismo, da guerra civil espanhola, muitos intelectuais americanos foram atraídos para o Partido Comunista, mas os espíritos mas críticos censuraram o oportunismo da Frente Popular, que levava o partido a cortejar Roosevelt e a saudar o New Deal. Espantaram-se e horrorizaram-se com os julgamentos de Moscou e as manobras equívocas e os rituais bizarros do stalinismo. O trotskismo lhes parecia como uma brisa fresca irrompendo em meio ao ar sufocado da esquerda e abrindo novos horizontes. Homens de letras responderam ao pathos dramático da luta de Trotski e à sua eloquiência e seu gênio literário. O trotskismo tornou-se como que uma moda que deixaria muitas marcas na literatura americana. Entre os escritores, especialmente críticos, por ele influenciados estavam Edmund Wilson, Sidney Hook, James T. Farrell, Dwight Macdonald, Charles Malamud, Philip Rahv, James Rorty, 
Harold Rosenberg, Clement Greenberg, Mary MacCarthy, (...) (Meyer Schapiro) e muitos, muitos outros."150

No final de 1937, Philip Rahv e William Phillips romperam com o PCEUA e deram nova orientação para a Partisan Review. As posições de Trotski ressoaram como uma alternativa contra o controle sobre as artes e contra o antimodernismo defendido pelo PCEUA. Deutscher relata: "Dirigida por (Ravh e Phillips), a revista vinha sendo publicada sob os auspícios dos John Reed Clubs e, indiretamente, do Partido Comunista. Os diretores, porém, irritados pela interferência do partido na literatura, constrangidos pelas suas oscilações políticas e abalados pelos julgamentos de Moscou, suspenderam a publicação. (Em 1937) (...) voltaram a editá-la, mas modificaram-lhe a orientação: a Partisan Review ficava a favor do socialismo revolucionário e contra o stalinismo. (A aproximação entre os editores da revista e Trotski foi difícil, pois ele) (...) tinha dúvidas quanto à seriedade da dedicação da Partisan Review ao socialismo revolucionário. (...) Em fins do ano, à medida que a revista se tornava mais violenta em seu anti-stalinismo, o gelo se quebrou. $\mathrm{O}$ momento de maior aproximação da revista com Trotski surgiu quando Breton e Rivera, inspirados por Trotski, publicaram em suas páginas o Manifesto pela liberdade da arte e convocaram uma Federação Internacional dos Autores e Artistas Revolucionários, para resistir às interferências totalitárias na literatura e nas artes."

Breton chegou ao México, em 1938, com o intuito de conversar com Trotski. Não fora lá para uma entretien, mas para se aproximar do líder revolucionário e dissipar de uma vez por todas o malestar reinante entre os surrealistas e os trotskistas franceses. Essa animosidade principiou no interior do grupo surrealista com a ruptura de relação entre Pierre Naville e André Breton, e ainda contou com a saída de outros membros que

\footnotetext{
${ }^{150}$ DEUTSCHER, I. Trotski: o profeta banido. Rio de Janeiro: Editora Civilização Brasileira, 1984, pp. 442-443. (parênteses nossos). Até o momento da invasão da Finlândia pelos exércitos soviéticos em 1939, Max Shachtman, James P. Cannon e James Burnham foram os principais aliados de Trotski na coordenação dos trabalhos das sessões da Internacional e na tentativa de reordenar a ação do proletariado mundial. Após a realização da IV Internacional, intensificou-se a correspondência entre Nova York e a Casa Azul. Era apenas o início das atividades, em que se decidiam as novas tarefas sem que a Internacional tivesse algum aumento substancial de seus participantes. Não se esperava uma adesão da noite para o dia, mas uma alternativa ao papel exercido pela Terceira Internacional, que recuara de sua posição internacionalista. Além disso, esses militantes estiveram envolvidos de forma decisiva na formação de uma comissão internacional para defesa da oposição política russa nos processos de Moscou em 1937 e 1938, quando o terror no regime adquire seu aspecto mais brutal com as famosas troikas, ou tribunais de massa, que condenaram milhares de pessoas à morte. Trotski, sem titubear, toma a iniciativa da defesa de seus velhos companheiros de oposição ao stalinismo. Ele mesmo seria vítima daqueles tribunais, que sem apelo da decisão, o condenariam à morte por traição à revolução. O líder do exército vermelho vitorioso era declarado culpado perante a Revolução de Outubro, que ele ajudara a construir.

${ }^{151}$ Idem, ibidem, pp. 443-444. (parênteses nossos).
} 
condenavam a aproximação daquele movimento artístico com o comunismo. Contudo, Breton estava decidido a aproximar os surrealistas da revolução comunista. Por sua vez, Trotski acolheu muito bem a iniciativa e tinha grande interesse pelo encontro com vistas a formar um agrupamento político e artístico consistente não somente na Europa, mas também nos Estados Unidos e no mundo. Tanto ele como Breton já haviam feito críticas severas à linha oficial das artes na URSS. ${ }^{152}$ Com a iniciativa, Trotski ansiava por apresentar uma alternativa à arte dirigida e ganhar a confiança de intelectuais e artistas para uma nova revolução.

Em 25 de julho de 1938, o "Manifesto por uma arte revolucionária independente" era publicado, com as assinaturas de André Breton e Diego Rivera, na Partisan Review. Como se sabe, Breton declarou mais tarde, em novembro daquele ano, numa de suas entrevistas na França, que a idéia do manifesto surgira a partir de uma proposta que Trotski lhe fizera e que a defesa de uma concepção libertadora da arte foi decisiva na elaboração do texto final: "Esse manifesto apareceu sob a assinatura de Diego Rivera e a minha (...). Esclareço que se deve mais a Trotski do que a Rivera e a

\footnotetext{
${ }^{152}$ Na França, André Breton e Paul Eluard foram expulsos do Partido, em 1933, depois de apoiarem as críticas de Ferdinand Alquié sobre a 'cretinização' do regime soviético. No mesmo ano, Breton aproximou-se da Oposição Internacional de Esquerda. Os antecedentes de luta em favor de Trotski foram a moção contra sua expulsão da URSS, em 1929, e a campanha de asilo político que, Breton ajudou a realizar e que conseguiu a permanência provisória de Trotski na França pelo período de dois anos, entre 1933 e 1935. Além disso, Breton foi co-autor de um manifesto contra a expulsão de Trotski, intitulado "Planeta sem passaporte" e publicado na imprensa francesa em 24 de abril de 1934. Esse Manifesto contou com cerca de vinte e uma assinaturas de intelectuais, poetas, artistas - entre as quais a do próprio Breton, de Paul Éluard, de Benjamin Péret, de Yves Tanguy -, além de outras personalidades francesas e estrangeiras. Cf. NADEAU, M. História do surrealismo. São Paulo: Perspectiva, 1985, pp. 160-161. Em primeiro de abril de 1935, convidado por Vitezslav Nezval e Karel Telge para uma conferência em Praga, Breton questionava o estreitamento entre a política comunista e a mensagem artística com a seguinte pergunta: "Rigorosamente falando, existe, ou não, uma arte de esquerda capaz de se defender, ou seja, apta a justificar sua técnica 'avançada' pelo simples fato de se achar a serviço de um estado de espírito de esquerda?" BRETON, A. "Posição Política do Surrealismo" In Manifestos do surrealismo. Rio de Janeiro: NAU Editora, 2001, p. 251. Para ele, não era possível indicar o caráter de uma nova manifestação artística pela sua adequação ao ideal revolucionário, nos termos de uma expressão necessária e explícita. Com isso, tínhamos a defesa da autonomia do surrealismo. Ao contrário de uma validação da arte através da simples transposição dos assuntos de sua época, a atualidade crítica da arte poderia ser encontrada somente em uma análise aprofundada e em uma elucidação analítica de seus recursos, que levasse ao conhecimento da predileção do artista pelo desenvolvimento de uma técnica e não de outra. Essas razões internas e, ao mesmo tempo, objetivadas de forma sistemática nos forneceriam o vínculo que se quer existente entre a arte moderna e a revolução. Breton rompia com o Partido Comunista da URSS e da França, sem que isso implicasse uma ruptura com a Revolução. A arte expressava seu tempo, através de seus meios e no desenvolvimento da técnica segundo a vontade de cada artista. Desse modo, ela fazia parte da empreita revolucionária. Seu desenvolvimento, sem a predestinação de uma idéia e sem qualquer barreira, na forma da técnica empregada pelo artista era, para Breton, a possibilidade ambicionada ou não de se "traduzir o mundo numa linguagem nova, que essa ambição tentou, ao longo do caminho, submeter todas as demais, e não podemos impedir-nos de ver aí a razão da influência única no mundo que, no plano poético e talvez no plano moral, esta obra exerce, do brilho excepcional que ela continua a desfrutar". Idem, ibidem, p. 257.
} 
mim a independência total ali reivindicada do ponto de vista artístico". ${ }^{153}$ Partia-se desse ponto para dois objetivos principais vinculados à elaboração do Manifesto: a tomada de posição frente ao dirigismo nas artes e a fundação de uma federação internacional que reunisse intelectuais e artistas do mundo inteiro em prol da revolução comunista e que fizesse fente às organizações culturais e ações governamentais dos stalinistas, dos nazistas, dos rooseveltistas, etc.

Naquela ocasião, Breton não mencionara o fato de que o nome de Rivera substituíra o de Trotski por uma questão estratégica de se conseguir uma disposição mais favorável da vanguarda artística internacional com a FIARI e, talvez, uma adesão de grande parte da intelectualidade que apoiava o regime stalinista. O Manifesto foi redigido a duas mãos, sendo traçado em linhas gerais por Breton e, posteriormente, desenvolvido por Trotski, que "colava e cortava", acrescia e suprimia partes do texto inicial de Breton ${ }^{154}$. Realizaram-se várias reuniões entre os dois, que resultaram em várias anotações nas margens das páginas até a elaboração da versão final. Esse texto foi, em suma, o produto de um conjunto de contribuições pessoais, mas que sinalizavam um entendimento fundamental e comum sobre as artes. Sua importância histórica foi apresentar uma alternativa franca e aberta para a atividade livre da arte moderna, a despeito do fracasso da Federação Internacional. Assim, o Manifesto não foi somente uma resposta ao realismo socialista, mas também a todas as formas de cooptação da arte em favor de interesses exclusivos da política.

Maurice Nadeau afirmou que os esforços de Breton para fundar a Federação Internacional na França não deram frutos por causa da iminência do conflito armado que tomaria conta da Europa: "De volta a Paris, (...) (Breton) dedica-se à criação de uma seção francesa da FIARI. (...) O momento não era mais para a arte independente. Além disso, discussões internas do grupo surrealista (...) infelizmente foram levadas para a FIARI. De outro lado, os 'proletários', como Marcel Martinet e Henry Poulaille, revelam uma influência demasiado grande dos surrealistas sobre a organização. Em vez de contrabalançá-la por uma contribuição equivalente, fecham-se em suas posições. Tentativa interessante de reagrupamento no plano revolucionário dos artistas independentes, a FIARI entra em decadência antes mesmo de ter começado sua

\footnotetext{
${ }^{153}$ BRETON, A. "Visita a Leon Trotski" In BRETON, A. \& TROTSKI, L. Por uma arte revolucionária independente. São Paulo: Paz e Terra: CEMAP, 1985, p. 62. (parênteses nossos).

${ }^{154}$ Cf. ROCHE, G. "Introdução" In BRETON, A. \& TROTSKI, L. Op. cit., pp. 20-21.
} 
tarefa."155 Ainda que, para Nadeau, as medidas para o tempo de paz não fossem as mesmas que em tempo de guerra, houve a expectativa de Breton de que a nova federação constituísse um meio de propagação de uma verdadeira consciência artística.

A iniciativa de fundar a FIARI partiu de Breton, sendo a conclusão emergente e prática do Manifesto por uma arte revolucionária independente. Ele diz: "milhares e milhares de pensadores e de artistas isolados, cuja voz é coberta pelo tumulto odioso dos falsificadores arregimentados, estão atualmente dispersos no mundo. (...) Toda tendência progressiva na arte é difamada pelo fascismo como uma degenerescência. Toda criação livre é declarada fascista pelos stalinistas. A arte revolucionária independente deve unir-se para a luta contra as perseguições reacionárias e proclamar bem alto seu direito à existência. Uma tal união é o objetivo da Federação Internacional da Arte Revolucionária Independente (FIARI) que julgamos necessário criar."156 Com isso, Breton e Trotski aspiravam a melhores condições para o desenvolvimento das artes, mas a iniciativa esbarrava na mesma dificuldade encontrada no momento da fundação da IV Internacional e verificava-se um retraimento crescente dos debates em torno das questões da arte ou das escolhas políticas, no qual as iniciativas artísticas e os discursos foram substituídos pelas armas.

Duas posições norteiam o "Manifesto por uma arte revolucionária independente", a saber: a condenação da arte dirigida e a defesa da arte independente. Por um lado, a arte dirigida sinalizava a batalha circunstancial vencida pelas forças contra-revolucionárias, por outro, a arte independente fazia parte das forças empenhadas no processo revolucionário de transformação da realidade. Trotski e Breton afirmavam que a arte independente, mesmo não substituindo a política no conflito de classes, estava naturalmente vinculada à realização dos ideais políticos mais revolucionários. ${ }^{157}$ $\mathrm{Na}$ abertura do Manifesto, os dois autores descrevem o estado vigente das artes, da cultura e da ciência: "Pode-se pretender sem exagero que nunca a civilização humana

\footnotetext{
${ }^{155}$ NADEAU, M. História do surrealismo. São Paulo: Editora Perspectiva, 1985, pp. 160-161. (parênteses nossos).

${ }^{156}$ BRETON, A. \& TROTSKI, L. Por uma arte revolucionária independente. São Paulo: Paz e Terra: CEMAP, 1985 , pp. 45-46.

${ }^{157}$ Cf. WALD, A. M. The New York intellectuals: the rise and decline of the anti-stalinist left from the 1930s to the 1980s. North Carolina: The University of North Carolina Press, 1987, p. 145. Para Wald, Trotski afirmava no Manifesto que, a arte se deixada livre, confluiria com os ideais políticorevolucionários e, por conseguinte, colaboraria para a abertura de uma nova etapa na história da humanidade. Ao contrário de Guilbaut, Wald entendeu o surgimento do Manifesto como a efetivação de uma alternativa para a arte dirigida desde que se efetivasse a alternativa política revolucionária. Guilbaut erra, quando afirma que o Manifesto foi uma solução ambígua sobre a relação entre arte e revolução. Cf. GUILBAUT, S. How New York stole the idea of the modern art - abstract expressionism, freedom, and the cold war. Chicago: The University of Chicago Press, 1985, pp. 26-29.
} 
esteve ameaçada por tantos perigos quanto hoje. Os vândalos, com auxílio de seus meios bárbaros, isto é, deveras precários, destruíram a civilização antiga num canto limitado da Europa. Atualmente, é toda a civilização mundial, na unidade de seu destino histórico, que vacila sob a ameaça das forças reacionárias armadas com toda a técnica moderna. Não temos somente em vista a guerra que se aproxima. Mesmo agora, em tempo de paz, a situação da ciência e da arte se tornou absolutamente intolerável."158

Trotski e Breton mostravam que em países como a Alemanha nazista e a URSS, a arte livre era considerada um perigo para a manutenção da ordem social e passou a ser ali controlada e dirigida pelo governo. Se o que de mais fundamental na arte é o exercício de sua liberdade de criação, "ora, (diziam os autores), o mundo atual nos obriga a constatar a violação cada vez mais geral dessas leis (leis específicas a que está sujeita a criação intelectual), violação à qual corresponde necessariamente um aviltamento cada vez mais patente, não somente da obra de arte, mas também da personalidade "artística". O fascismo hitleriano, depois de ter eliminado da Alemanha todos os artistas que expressaram em alguma medida o amor pela liberdade, fosse ela apenas formal, obrigou aqueles que ainda podiam consentir em manejar uma pena ou um pincel a se tornarem os lacaios do regime e a celebrá-lo de encomenda, nos limites exteriores do pior convencionalismo. Exceto quanto à propaganda, a mesma coisa aconteceu na URSS durante o período de furiosa reação que agora atingiu seu apogeu."159

No quarto parágrafo do Manifesto, escrito exclusivamente por Trotski, faz-se a crítica aos liberais que defendiam os ideais democrático-burgueses e o realismo social na arte norte-americana. Diz Trotski: "É evidente que não nos solidarizamos por um instante sequer, seja qual for seu sucesso atual, com a palavra de ordem: 'nem fascismo nem comunismo', que corresponde à natureza do filisteu conservador e atemorizado, que se aferra aos vestígios do passado 'democrático'. A arte verdadeira, a que não se contenta com variações sobre modelos prontos, mas se esforça por dar uma expressão às necessidades interiores do homem e da humanidade de hoje, tem que ser revolucionária, tem que aspirar a uma reconstrução completa e radical da sociedade, mesmo que fosse apenas para libertar a criação intelectual das cadeias que a bloqueiam e permitir a toda humanidade elevar-se a alturas que só os gênios isolados atingiram no passado. Ao

\footnotetext{
${ }^{158}$ BRETON, A. \& TROTSKI, L. Op. cit., p. 35.

${ }^{159}$ Idem, ibidem, p. 37. (parênteses nossos).
} 
mesmo tempo, reconhecemos que só a revolução social pode abrir a via para uma nova cultura."160

A revolução nas artes faz parte da revolução completa da sociedade, mas a arte só pode encontrar seu lugar definitivo e harmônico e se realizar plenamente numa nova sociedade. Trotski e Breton comentam: "A (verdadeira) revolução comunista não teme a arte. Ela sabe que ao cabo das pesquisas que se podem fazer sobre a formação da vocação artística na sociedade capitalista que desmorona, a determinação dessa vocação não pode ocorrer senão como resultado de uma colisão entre o homem e um certo número de formas sociais que lhe são adversas. Essa única conjuntura, a não ser pelo grau de consciência que resta adquirir, converte o artista em seu aliado potencial. ${ }^{161}$ (...) Segue-se que a arte não pode consentir sem degradação em curvar-se a qualquer diretiva estrangeira e a vir docilmente preencher as funções que alguns julgam poder atribuirlhe, para fins pragmáticos, extremamente estreitos. Melhor será confiar no dom de prefiguração que é o apanágio de todo artista autêntico, que implica um começo de resolução (...) das contradições mais graves de sua época e orienta o pensamento de seus contemporâneos para a urgência do estabelecimento de uma nova ordem."

Se, no parágrafo nove de seu ensaio preliminar, Breton propunha que o lema do Manifesto fosse: "TODA LICENÇA EM ARTE, EXCETO CONTRA A REVOLUÇÃO PROLETÁRIA", por sua vez Trotski corrigiu-o escrevendo "toda licença em arte"163, e arrematou, "Na época atual, (...) o artista, sem ter sequer necessidade de dar a sua dissidência social uma forma manifesta, vê-se ameaçado da privação do direito de viver e de continuar sua obra pelo bloqueio de todos os meios de difusão. É necessário, desde este instante, que ele compreenda que seu lugar está além, não entre aqueles que traem a causa da revolução e (...) a causa do homem, mas entre aqueles que (...) permanecem como os únicos qualificados para ajudá-la a realizar-se e para assegurar por ela a livre expressão ulterior de todas as manifestações do gênio humano. (...) O que queremos: a independência da arte - para a revolução (;) a revolução - para a liberdade definitiva da arte." 164

\footnotetext{
${ }^{160}$ BRETON, A. \& TROTSKI, L. Op. cit., p. 38.

${ }^{161}$ Wald esclarece: "(O Manifesto) repetiu os sentimentos expressos (por Trotski) em "Arte e política em nossa época" e enfatizou que o artista "é o aliado natural da revolução"." WALD, A. M. The New York intellectuals: the rise and decline of the anti-stalinist left from the 1930s to the 1980s. North Carolina: The University of North Carolina Press, 1987, p. 145.

${ }_{162}$ BRETON, A. \& TROTSKI, L. Op. cit., pp. 39-40.

163 Idem, ibidem, p. 42. (Caixa alta de Breton).

${ }^{164}$ Idem, ibidem, pp. 44 e 46.
} 
Uma das principais questões discutidas no Congresso de Fundação da IV Internacional foi a tese sobre a defesa incondicional da URSS, em caso de ameaça de invasão durante o novo conflito mundial. Essa defesa incondicional mantinha-se atrelada ainda às conclusões de Lênin sobre o período pós-revolucionário russo. Naquele momento, a defesa da URSS justificava-se como ação contra a ameaça imperialista iminente, fosse ela agressão de uma única potência ou de uma coalizão. Sabia-se que Stálin mantinha aproximação não totalmente declarada com a França e a Inglaterra, como estratégia defensiva em caso de guerra. Assim, a tese de defesa da URSS foi aprovada no Congresso da IV Internacional, e considerava legítima a aliança do governo soviético com as potências comprometidas na eventual guerra imperialista. Não houve nenhuma restrição às deliberações unânimes da Internacional até que vieram a público os acordos secretos entre Hitler e Stálin.

Em 23 de agosto de 1939, Hitler firmou um pacto secreto de não-agressão com a URSS, também chamado de pacto Ribbentrop-Molotov, garantindo que não fosse atacado em duas frentes. Quando a notícia veio à tona, iniciourse um processo de intensa discussão dentro das bases do Partido dos Trabalhadores Socialistas (S.W.P.) nos Estados Unidos. Havia, por parte dos oposicionistas do Comintern, indignação perante o apoio indireto dado ao regime nazista. ${ }^{165}$ No entanto, a situação política internacional não oferecia muitas alternativas e mesmo que Stálin já tivesse tentado um acordo com Hitler em 1934, é fato conhecido que houve várias tentativas frustradas da diplomacia russa em estabelecer acordos com a Grã-Bretanha e com a França. A aliança com Hitler ocorreu depois de uma última tentativa da URSS em promover uma aliança defensiva com as democracias francesa e inglesa.

A alegação apresentada por França e Grã Bretanha, contra uma possível aliança com Stálin, era o repúdio ao sistema político comunista. Temia-se, com isso, uma influência maior dos movimentos trabalhistas e, principalmente, dos partidos comunistas nesses países. Em primeiro de setembro de 1939, deu-se o início das

\footnotetext{
${ }^{165}$ Não apenas os trotskistas, mas também muitos intelectuais e militantes de esquerda e liberais norteamericanos deixaram de apoiar a URSS, logo após as notícias do pacto entre Stálin e Hitler. Serge Guilbaut comenta: "Para muitos (militantes, artistas e) intelectuais o inverno de 1939, que presenciou a repartição da Polônia e a entrada da França e da Inglaterra na guerra, foi um período dramático, um período de reconsideração e reavaliação de tudo aquilo em que os intelectuais de esquerda acreditavam (...). Aos olhos de liberais surpresos, "a crise que o pacto nazi-soviético representou para os escritores americanos foi espiritual, ntelectual e moral." Intelectuais que haviam depositado sua fé na Frente Popular ficaram perdidos quando aquela atrativa estrutura entrou em colapso." GUILBAUT, S. How New York stole the idea of the modern art - abstract expressionism, freedom, and the cold war. Chicago: The University of Chicago Press, 1985, p. 39.
} 
invasões expansionistas de Hitler e das potências do Eixo na Europa, e a situação de consenso entre os militantes norte-americanos e Trotski ganhou novos contornos. $\mathrm{O}$ pacto entre Alemanha e URSS estabelecia, num acordo informal e secreto, a invasão e a divisão da Polônia e ainda mais a conquista das áreas estratégicas para os dois países, a Finlândia e os países dos Balcãs. Nas alas minoritárias do trotskismo, em particular no grupo a que Pedrosa pertencia, passa-se rapidamente da discussão sobre a defesa incondicional para a condenação da política belicista promovida pelo stalinismo.

Em 9 de novembro de 1939, pouco antes da invasão da Finlândia por tropas russas, Mário Pedrosa redige um ensaio intitulado "The defense of the USSR in the present war", que colocava em dúvida a questão da defesa incondicional da URSS. A proposta do ensaio fez parte de uma série de manifestos redigidos por vários militantes comunistas e socialistas contra a ação combinada entre Hitler e Stálin. O grupo fracional de Pedrosa contestava, em revistas como a New International, as principais alegações de Trotski sobre a defesa da URSS na guerra. Por sua vez, o ensaio de Pedrosa passava da discussão sobre a tese defensiva, proposta por Trotski, para a caracterização da natureza do Estado soviético. Pedrosa julgava que a discussão sobre a defesa ou não da URSS na guerra era resultado da própria razão de ser do Estado soviético e do papel que ele exercia no processo revolucionário. Em outras palavras, para se chegar à tese da defesa incondicional era preciso entender que o poder exercido com exclusividade pela burocracia e a implementação de sua política internacional não interferiam nas bases das conquistas econômicas da URSS. ${ }^{166}$

Essa era a opinião defendida por Trotski, pois ele entendia que a política internacional russa oscilava cada vez mais no apoio ao imperialismo das potências européias, sem que isso resultasse em qualquer mudança substantiva do Estado soviético, ainda que não descartasse em momento algum a hipótese da contra-revolução. A conciliação de apoio às potências européias fazia parte da prerrogativa de defesa e, ao mesmo tempo, da tentativa de manter em caráter provisório as conquistas da revolução nos limites do país. Nessa elação de forças entre as potências ocidentais, Trotski contrariou a opinião comum de que a URSS consolidaria um tratado com a França e a Inglaterra, contra o imperialismo alemão, e previu o acordo entre Hitler e Stálin: "Depois de esmagar as massas soviéticas e romper com a revolução internacional, a

\footnotetext{
${ }^{166}$ Sobre a polêmica entre o grupo fracional da IV Internacional e Trotski, ver ensaio de Dainis Karepovs, intitulado "Mário Pedrosa e a IV Internacional". Nele, o autor trata do desligamento de Pedrosa da IV Internacional. KAREPOVS, D. "Mário Pedrosa e a IV Internacional" In Mário Pedrosa e o Brasil, (org. José Castilho Marques Neto). São Paulo: Fundação Perseu Abramo, 2001, pp. 99-130.
} 
camarilha do Kremlin se transformou em um joguete do imperialismo. Nos últimos cinco anos a diplomacia de Stálin foi, em todos os assuntos especiais, só um reflexo (...) da de Hitler."167

Para os trotskistas, a III Internacional impedia as ações do internacionalismo revolucionário, pois ela servia apenas aos interesses políticos e econômicos internos da URSS. Porém, a caracterização da URSS do ponto de vista dualista - revolucionária e contra-revolucionária ao mesmo tempo - era a chave para se entender a defesa incondicional da propriedade nacionalizada como base para o socialismo e a condenação da política dirigente. Diz Trotski: "A luta contra a guerra, o imperialismo e o fascismo exigem uma luta incansável contra o stalinismo, manchado de crimes. Quem defende direta ou indiretamente o stalinismo, quem cala suas traições ou exagera sua força militar, é o pior inimigo da revolução, dos povos oprimidos, do socialismo. Quanto antes for derrocada a camarilha do Kremlin pela ofensiva armada dos trabalhadores, maiores serão as possibilidades de uma regeneração socialista da URSS, mais próximas e amplas as perspectivas da revolução internacional." 168

Leon Trotski entendia a defesa incondicional da URSS, como salvaguarda das conquistas da Revolução de Outubro, a saber: o processo de nacionalização dos meios de produção. Para ele, a deposição do poder dirigente permitiria a reconstrução e o desenvolvimento dessa base socialista da URSS. Somente isso garantiria a volta ao internacionalismo revolucionário, posto que seria mais fácil destituir a casta mantida no Kremlin do que reiniciar um processo de expropriação da burguesia nacional que poderia contar com o apoio de outros países capitalistas. A tarefa da nova militância internacionalista seria iniciar a formação dos movimentos proletários em todos os países e manter a crítica ao regime stalinista. Para Trotski, o final da Segunda Guerra marcaria o início de um processo revolucionário internacional e a destituição da burocracia na URSS. Essa alternativa parecia mais plausível, embora ele não descartasse o arrefecimento das forças revolucionárias em todo o mundo.

\footnotetext{
167 TROTSKI, L. “A recent lesson” In New International, New York, dezembro de 1938. Disponível em: <http://www.ceip.org.ar/escritos/Libro6/html/T10V111.htm\#_ftn1>. Acesso em: 20 de março de 2002. Para Trotski, Stálin colaborava efetivamente com o regime nazista desde sua campanha contra a frente única.

${ }^{168}$ Idem, ibidem.
} 


\section{Política e cultura: a ação dos Estados Unidos na América Latina}

A Segunda Guerra Mundial não só impediu o aumento dos movimentos revolucionários liderados pelos trabalhadores na Europa, mas também contribuiu para a consolidação de novas relações políticas no continente americano. Mesmo que, em 1939, os Estados Unidos reafirmassem sua política de neutralidade e de isolamento frente à guerra na Europa, eles não tardaram em estabelecer vínculos mais fortes na América Latina. Estavam interessados em defender seus interesses comerciais e temiam tanto a influência crescente da Alemanha, em países como a Argentina e o Brasil, quanto o surgimento de movimentos revolucionários e também o crescimento do antiamericanismo. A história das relações políticas entre os Estados Unidos e os demais países da América se baseava no "direito manifesto" - propugnado pela Doutrina Monroe - com a aplicação do "big-stick" e da "dollar diplomacy". Em 1933, Franklin D. Roosevelt anunciou uma nova fase diplomática denominada Política da Boa Vizinhança. Para além da mera retórica governamental sobre cooperação educativa, cultural e econômica para o desenvolvimento mútuo dos países americanos, a nova política visava fixar a influência dos Estados Unidos no continente, proteger os interesses de grandes companhias norte-americanas e abrir ou recuperar mercados fornecedores de matérias-primas e consumidores de produtos industrializados.

Gerard Colby e Charlotte Dennet relatam a disputa política e econômica entre Alemanha e Estados Unidos pela América Latina: "Em abril de 1939, quando Adolf Berle juntava forças para 'expulsar' as linhas aéreas alemãs da América Latina, Laurence Rockefeller foi convidado para almoçar com Robert W. Johnson (...). A Johnson \& Johnson tinha grandes interesses na América Latina. Seus maiores concorrentes eram as empresas alemãs, especialmente a Bayer. Como a maior parte das empresas farmacêuticas, ela dependia do Amazonas para conseguir as plantas usadas na fabricação de remédios. (...) Johnson estava preocupado com relatos sobre a crescente presença empresarial alemã na América Latina. Berlim, reconhecendo que a região seria uma fonte de matérias-primas só superada pela Europa meridional, tinha estimulado um enorme crescimento do comércio. Os latino-americanos viram neste comércio um alívio bem-vindo à queda nas compras anglo-americanas no período de depressão. Por volta 
de 1940, muitos países latino-americanos estavam vendendo duas vezes mais para a Alemanha do que comprando dela. Os aviões alemães estavam entre os mais luxuosos e sofisticados artigos vendidos para a América Latina. Estas vendas ajudaram a corrigir o déficit comercial da Alemanha com o hemisfério, enquanto aumentavam a dependência regional da tecnologia alemã. Também proporcionou trunfos de propaganda para os nazistas."169

Aproveitando-se da situação, Getúlio Vargas demonstrava interesse em fechar acordos tanto com o governo alemão quanto com o norte-americano. Antonio Pedro Tota comenta a disputa ideológica travada entre o american way of life e ofronterlebnis alemão no Brasil: “(Essa última formulação), que (parecia) (...) transformar a Alemanha nazista em uma notável potência mundial, chamava a atenção de parte dos oficiais do Exército brasileiro. O general Pedro Aurélio de Góis Monteiro foi convidado a assistir a um dos muitos e grandiosos desfiles-manobras militares em Berlim. Góis Monteiro não chegou a visitar a Alemanha, mas de uma forma ou de outra havia, no ideário doa militares que fizeram a Revolução de 1930, um projeto de expansão auto-sustentada. Embora não contássemos com um passado de experiências técnicas (...), tínhamos, ao menos, recursos naturais incomparavelmente maiores que os da Alemanha. (...) Enquanto não conquistasse sua independência técnica, o Brasil poderia comprar, pelo sistema de compensações oferecido pelos alemães, armas e máquinas (da indústria germânica). Na transação não haveria exatamente dinheiro, mas troca de produtos por produtos. Já em 1935 '[...] o governo brasileiro fez um acordo para uma compensação informal com a Alemanha, apesar de ter assinado um tratado de comércio bilateral com os Estados Unidos",. 170

169 COLBY, G. \& DENNETT, C. Seja feita a vossa vontade: a conquista da Amazônia: Nelson Rockefeller e o evangelismo na idade do petróleo. Rio de Janeiro: Record, 1998, p. 145. Marat Antiásov expõe o plano norte-americano de construção de uma fortaleza americana para a proteção da civilização ocidental dos ataques revolucionários do comunismo e principalmente da barbárie nazi-fascista: "Em 1939 começou a segunda guerra mundial. Os principais rivais dos Estados Unidos, Inglaterra e Alemanha, se encontraram de mãos atadas. Os países latino-americanos ficaram em uma situação difícil por consequiência da perda dos mercados e fornecedores europeus. Para a expansão norte-americana criavamse condições excepcionais. A esse período correspondeu um considerável crescimento das inversões e do comércio estadunidenses nos países latino-americanos. A guerra permitiu aos Estados Unidos, alcançar também êxitos políticos no continente. (Os) Estados Unidos intensificaram ainda mais a difusão do ideal de 'comunidade' panamericana como 'continente de paz', ao qual com esforços conjuntos era preciso proteger e fortalecer. "O destino nos encarrega a tarefa de criar no Hemisfério Ocidental uma fortaleza onde ainda se pode preservar a civilização", sublinhava Franklin Roosevelt em setembro de 1939, ao pronunciar seu discurso no Congresso" ANTIÁSOV, M. Panamericanismo: doctrina y hechos. Moscou: Editorial Progresso, 1986, pp. 52-53.

170 TOTA, A. P. O imperialismo sedutor: a americanização do Brasil na época da Segunda Guerra. São Paulo: Companhia das Letras, 2000, p. 26. (parênteses nossos). Ainda que haja muita controvérsia sobre até que ponto houve ou não um alinhamento político do governo Vargas com a Alemanha nazista, Pedro 
O interesse dos Estados Unidos pela América Latina fez com que a administração de Franklin D. Roosevelt enviasse técnicos para fazer estudos específicos sobre recursos minerais e naturais a serem explorados. Adveio daí, por exemplo, os primeiros mapas geológicos detalhados sobre o solo brasileiro. Em 1939 e 1940, o governo norte-americano intensificou acordos de cooperação com os demais países americanos a fim de selar sua influência no Continente. Pedro Tota relata a importância estratégica conquistada pela América Latina no biênio: "As Américas, não só os Estados Unidos, tinham, segundo Roosevelt, de se transformar numa fortaleza do hemisfério. Na reunião pan-americana de setembro-outubro de 1939, os países americanos, instados pelos Estados Unidos, formaram uma comissão, que deu origem ao Conselho Econômico e Financeiro Interamericano. Os delegados dos Estados Unidos também conseguiram aprovar a formação de uma zona de neutralidade de trezentas milhas em torno do continente americano. (...) Depois que o exército nazista invadiu a Dinamarca, em abril de 1940, a política americana precisava com urgência encontrar fórmulas que garantissem a segurança do continente. A miséria e o atraso econômico dos países latino-americanos poderia propiciar revoluções lideradas por nacionalistas, socialistas ou simpatizantes do nazi-fascismo, movimentos que punham em xeque os interesses dos Estados Unidos. (...) Aos olhos (...) dos norte-americanos, a fraqueza não só econômica e social, mas também militar - dos países da América Latina era uma ameaça direta aos Estados Unidos."

Governo e empresários norte-americanos, como Nelson Rockefeller, estavam preocupados não só com a influência e a espionagem alemã na América Latina, mas também com as agitações trabalhistas crescentes. Se o nacionalismo, o comunismo ou o fascismo progredissem no Continente e fossem aliados do descontentamento das populações empobrecidas e excluídas, aumentariam os riscos de sobrevivência para as

\footnotetext{
Tota assinalou a ambigüidade política astuciosa de Vargas em lidar com norte-americanos e com alemães: "As formulações dos militares encontravam, no entanto, obstáculos em nossa realidade histórico-cultural, que exigia mecanismos diferentes do modelo germânico. Vargas parecia entender melhor nossa formação. Ele procurava manter-se, no plano internacional, eqüidistante em relação tanto ao imperialismo mercantil ianque como ao imperialismo romancista germânico. Esse jogo não era facilmente entendido pelo estadomaior das Forças Armadas. Alguns hábeis e sensíveis assessores de Roosevelt, responsáveis pela política externa americana, estavam atentos aos conflitos de nossa política." Idem, ibidem, p. 27. De fato, o Governo de Vargas se aproximou dos países do Eixo no início da Segunda Guerra e, posteriormente, a partir de 1940, tornou-se aliado dos Estados Unidos. Para Edgard Carone, isso não caracterizava o Estado Novo como um regime fascista: "O Estado Novo é o primeiro momento em que se tenta dar um sentido mítico ao Estado, personalizado não só no que se denomina Estado Nacional, ou Nação, como também em seus expoentes e chefes. Em momento nenhum o mito atinge os ápices dos regimes fascistas, mas conteúdo e forma se delineam dentro do mesmo espírito e intenção." CARONE, E. O Estado Novo. Rio de Janeiro, São Paulo: Difel, 1976, p. 166.

${ }^{171}$ TOTA, A. P. Op. cit., pp. 46-47.
} 
empresas norte-americanas. $\mathrm{O}$ antiamericanismo encontraria condições propícias para crescer. Foi por causa disso que a administração de Roosevelt começou a articular uma nova política internacional e resolveu investir em programas sociais e acordos econômicos para minorar os problemas da América Latina. Gerard Colby e Charlotte Dennet relatam a guinada da política externa norte-americana no período da reeleição de Roosevelt: "Enquanto a Blitzkrieg nazista varria a França, funcionários da Compañia (Compañia de Fomento Venezolano) começaram a olhar para uma possível era do pósguerra em que os interesses Rockefeller competiriam livremente na Venezuela com as empresas de propriedade dos nazistas triunfantes. (...) Com a aproximação das eleições de 1940, dois grupos poderosos com preocupações coincidentes começavam a formular uma nova estratégia americana para a América Latina. Um grupo liderado pelo subsecretário de estado Summer Welles, o secretário-assistente Adolf Berle e o diretor da União Panamericana, Leo Rowe, era conhecido do público e da imprensa. O outro grupo se reunia em escritórios particulares de empresas e se centrava em Nelson Rockefeller. Os de fora o chamavam 'o grupo",172

Em 1940, o Departamento de Estado do governo Roosevelt, a Pan American Union e o Office of the Coordinator of Inter-American Affairs (OCIAA), chefiado por Rockefeller, acertaram uma política mais ou menos coesa de intervenção na América Latina. Maria de Fátima Tacuchian comenta o plano norte-americano: "Durante a guerra, a ênfase dada ao reforço e ampliação das funções das organizações panamericanas, tornou-se o instrumento principal da 'Política da Boa Vizinhança'. Desta forma, o governo norte-americano fortalecia as relações com o Hemisfério, sem abrir mão do poder de interferência exercido no passado, através de ações militares. (...) Um dos desdobramentos da recente política foi a implementação de uma propaganda massiva em prol dos valores da cultura americana. (...) Em junho de 1940, o presidente Roosevelt expressava (...) sua preocupação sobre as relações econômicas com a América Latina e as ações que deveriam ser empreendidas, tendo em vista o recente relatório preparado por Nelson Rockefeller, um ativo participante no setor petrolífero na Venezuela. Embora tratando primordialmente de questões econômicas, comerciais e administrativas, o documento recomendava a criação de um amplo programa de relações culturais, científicas e educativas (...). A proposta frisava a importância de se

172 COLBY, G. \& DENNETT, C. Seja feita a vossa vontade: a conquista da Amazônia: Nelson Rockefeller e o evangelismo na idade do petróleo. Rio de Janeiro: Record, 1998, p. 123. (parênteses nossos). 
garantir a posição política e econômica do país no Hemisfério, independentemente dos resultados da guerra na Europa, mas para tal seria de fundamental importância (promover o desenvolvimento econômico) (...) das Américas do Sul e Central, embora mantida num 'contexto de cooperação e dependência econômica",173.

A tentativa de formar a Fortaleza da Liberdade e de afastar do continente toda sorte de influência européia já surgira nos primeiros anos do governo de Roosevelt e se consolidou paulatinamente com as conferências pan-americanas. Tacuchian relata: "Em todas as propostas aparece, como denominador comum, a idéia de um hemisfério integrado, onde os países americanos estariam irmanados por um sistema de mútua cooperação, empenhados em proteger seus territórios contra a prática colonialista dos países europeus e, ao mesmo tempo, em promover o desenvolvimento econômico em termos continentais. (...) Assim formulada, a idéia foi apresentada e discutida em 1933, na Conferência Interamericana de Montevidéu, (...) confirmada e ampliada na Conferência Extraordinária Americana de Buenos Aires, em 1936, e na Conferência Interamericana de Lima, em 1938, na emergência do conflito mundial. (...) desta forma, Roosevelt firmava o compromisso de uma estreita cooperação política e econômica com os povos da América Latina e sinalizava para uma reorientação de propósitos, na tradicional política externa dos Estados Unidos para a região. (...) O Presidente americano propunha-se a desenvolver uma estratégia de aproximação baseada em três princípios: não intervencionismo, retorno a uma política de respeito mútuo e estabelecimento de um novo panamericanismo de solidariedade e de paz." 174

Nesse contexto, responsável pelas seções da América Latina, Mário Pedrosa colaborou com Trotski e com outros militantes na descrição da situação política no Continente, em 3 de setembro de 1938. O comentário dos militantes da IV Internacional detinha-se nas novas relações entre os Estados Unidos e os demais países do continente americano. Esse assunto tornava-se importante não só para denunciar a ação imperialista norte-americana sob a égide da Política da Boa Vizinhança, mas também para a derrubada definitiva da tese corrente, propugnada pelos stalinistas e difundida pelos partidos comunistas em escala internacional, sobre as condições potenciais e existentes de desenvolvimento político e de independência econômica nas colônias e ex-

\footnotetext{
173 TACUCHIAN, M. de F. G. Panamericanismo, propaganda e música erudita: Estados Unidos e o Brasil (1939-1948). Tese de doutorado apresentada ao Departamento de História da Faculdade de Filosofia, Letras e Ciências Humanas da Universidade de São Paulo. Orientador: Prof. Dr. Arnaldo Daraya Contier. 1998, p. 40. (parênteses nossos).

${ }^{174}$ Idem, ibidem, pp. 32-33.
} 
colônias. Tratava-se de questionar a possibilidade de conciliação entre a classe trabalhadora e a burguesia nacional como processo necessário para o desenvolvimento nacional e para a transformação posterior das relações produtivas e sociais. Ao contrário do que defendiam os stalinistas, os trotskistas vetaram a possibilidade de se pensar em um desenvolvimento econômico nacionalista nos países latino-americanos, por causa da relação de dependência entre as burguesias autóctones e a burguesia norte-americana.

A influência e a expansão econômica promovida pelos Estados Unidos no continente eram resultados de seu rápido desenvolvimento industrial e financeiro e dos problemas enfrentados pelos países europeus durante a Primeira Guerra Mundial. Esses fatores combinados davam àquele país a chance de estabelecer sua hegemonia sobre a maioria dos países da América Central, do Sul e do Caribe. Diz a tese apresentada pelos trotskistas: "Com o objetivo de obter a 'porta fechada' na América Latina, isto é fechada para os rivais e aberta para os Estados Unidos, o 'democrático' imperialismo ianque foi aguçado nos países latino-americanos pelas mais autocráticas ditaduras militares mestiças que têm servido para sustentar a estrutura imperialista e garantir sua ininterrupta corrente de super-utilidades ao Colosso do Norte. O caráter real do 'democrático' capitalismo ianque se revela melhor que tudo nas ditaduras tirânicas dos países latino-americanos, com as quais se acham indissoluvelmente ligadas sua sorte e sua política (...). Os déspotas sanguinários sob cuja oprimente dominação sofrem os milhões de operários e campesinos da América Latina, os Vargas e os Batistas, não são, em essência, mais que as ferramentas políticas dos 'democráticos' Estados Unidos imperialistas." 175

Em outubro de 1940, Pedrosa publicou o artigo "What next in Latin America" na revista New International - novo veículo de comunicação do Partido dos Trabalhadores (WP $)^{176}$-, no qual ele retomava as teses formuladas para o Congresso da IV Internacional. Não havia por que considerar a burguesia nacional como um suposto aliado em favor de uma autêntica independência nacional. Comenta Pedrosa: "O infortúnio de Vargas repete-se em larga extensão em outros países americanos. Na outra extremidade do continente, nós vemos agora a conclusão final do corajoso esforço de Cárdenas, na verdade o único representante progressista de toda a burguesia latinoamericana, que com seriedade experimentou obter a emancipação econômica de seu

\footnotetext{
175 Fragmento de tese aprovada pela Conferência de Fundação da Quarta Internacional, 03-09-1938. Cópia cedida gentilmente por Al Richardson.

${ }^{176} \mathrm{O}$ Workers Party foi fundado pelo grupo trotskista fracional, expulso da IV Internacional no início de 1940, do qual participaram: C. R. L. James, Max Shachtman, Mário Pedrosa, entre outros.
} 
país. A burguesia mexicana, por base e covardia, como todas as classes burguesas de países jovens em nossa época tempestuosa, permitiu que seu único líder capitulasse, preferindo se submeter e barganhar com os imperialistas antes do que ter de seguir o curso difícil da resistência enérgica." $" 177$

No alvorecer do século XX, a burguesia nacional dos países latino-americanos aproveitou-se dos conflitos de interesse entre os Estados Unidos e a Inglaterra e depois da entrada em cena da Alemanha nazista, para conquistar seu papel político e econômico dominante. Porém, dizia Pedrosa, em nenhum momento, ela acenou em favor de um processo impetuoso de independência nacional, temendo que isso pudesse aguçar as contradições sociais internas e proporcionar a chance de um levante dos trabalhadores. Pedrosa descreve as causas do insucesso da empreitada política da burguesia nacional: "A decadência do mercado mundial, o isolamento das economias nacionais e a crise crônica da agricultura - todos esses desenvolvimentos conduziram para a ruína econômica e também solaparam o poder político dos grandes proprietários de terras. (...) A industrialização fez sua entrada definitiva na América Latina; a luta entre o imperialismo americano e inglês tornourse mais violenta; e a classe burguesa nacional emergente apareceu sob o estágio político em ascensão da bandeira de emancipação econômica ... da dominação inglesa. (...) Os motins políticos do pósguerra em toda parte do continente são mais ou menos expressões desse fenômeno. Esta foi a era de ouro de seu nacionalismo burguês. Mas, por infelicidade, tornou-se cada dia mais claro que, como marxistas sul-americanos haviam provado, este nacionalismo jovem, que chegou tão tarde na cena internacional, não encontrou um ambiente favorável para o seu florescimento."178

Se alguns países conseguiram retomar o desenvolvimento econômico depois da crise de 1929, isso se deu em termos nacionais. Essa fora a época da autarquia alemã, do ‘socialismo em um só país' e das restrições alfandegárias nas colônias inglesas. Mesmo ali, Pedrosa alertava para o desdobramento dessa situação com o surgimento de um

\footnotetext{
${ }^{177}$ PEDROSA, M. "What next in Latin America" In New International, New York, outubro de 1940, p. 189. Cópia gentilmente cedida por Ernie Haberkern.

${ }^{178}$ Idem, ibidem, p. 189. Os "jovens marxistas sul-americanos", na alusão de Pedrosa, eram nada mais nada menos que seu grupo de amigos, Lívio Xavier e Aristides Lobo, e ele próprio. Em 3 de fevereiro de 1931, como participantes da Oposição Internacional de Esquerda, eles publicaram um artigo, intitulado "Esquisse d'une analyse de la situation economique et sociale au Bresil", sobre as condições e o desenvolvimento do capitalismo no Brasil, na revista francesa La lutte de classes. Cf. também PEDROSA, M. \& XAVIER, L. "Esboço de análise da situação brasileira" In A luta de classe, Rio de Janeiro, 03-02-1931, pp. 03-04. O artigo foi assinado por M. Camboa e Lyon, respectivamente: Mário Pedrosa e Lívio Xavier.
} 
novo tipo de imperialismo, que ele denominou como a necessidade de reconstruir a unidade da economia mundial sobre uma nova base "superimperialista": "Sombrio de fato é o futuro do estado nacional burguês na América Latina. Os grupos que, como resultado do fermento político das últimas duas décadas, ora encontram-se no poder estão exauridos. Consideremos, por exemplo, as grotescas acrobacias de um Vargas, um camaleão político do mais baixo tipo, que mantendo-se no poder, descobriu finalmente o 'nacionalismo' econômico. Em nome do qual ele obteve sucesso em seu último coup d'état. (...) A política nacionalista de Vargas é uma falência completa. Para justificar (essa política) (...), ele suspendeu os pagamentos dos débitos externos e se 'rebelou' contra a exploração imperialista, proclamando a independência econômica do Brasil. Dois anos depois dessas belas promessas, ele julgou necessário recomeçar o pagamento dos serviços do débito externo a despeito da completa exaustão dos recursos do país, e não tinha outra alternativa exceto começar a cortejar o capital internacional." ${ }^{179}$

No início da Segunda Guerra, agudizou-se a crise dos estados nacionais latinoamericanos, que não conseguiram até aquele momento desenvolver-se por força de sua dependência do capital externo. Os Estados Unidos assumiam cada vez mais a posição de nova potência superimperialista e sua influência na América Latina seria marcada pela política de empréstimos financeiros capazes de criar vínculos de dependência duradouros. Assim, a influência decrescente da Inglaterra e da Alemanha no continente deixava os Estados Unidos em uma situação privilegiada. Não se falava mais de uma influência territorial conseguida através de intervenções armadas na América Central ou Caribe, tal como fora a política de Woodrow Wilson, mas da nova política de Roosevelt para a América Latina. Diz Pedrosa: "O papel atual do imperialismo ianque na América Latina é puramente parasítico. Depois da crise de 1929 e das convulsões políticas que balançaram a América Latina, o governo americano decidiu parar os investimentos adicionais de capital em países ao sul do Rio Grande. (...) Portanto, o capitalismo americano (...) alimenta-se de rendas e de juros de pagamento sobre o capital investido ou emprestado há muito tempo (...). Esta política de rapina e parasítica vicejou precisamente sob o signo da 'boa vizinhança'.",180

A superioridade produtiva e militar dos Estados Unidos capacitava-os para o domínio econômico e político da América Latina. Para Pedrosa, os efeitos sobre os

\footnotetext{
${ }^{179}$ PEDROSA, M. "What next in Latin America” In New International, New York, outubro de 1940, p. 189. (parênteses nossos).

${ }^{180}$ Idem, ibidem, p. 189.
} 
demais países do continente eram evidentes. Ele então cogitou a possibilidade de uma disputa intercontinental entre Roosevelt e Hitler, que tomariam posse das áreas de influência que antes pertenciam ao Império Britânico. Na América Latina, esse novo poder "superimperialista" promoveria o estabelecimento de uma autarquia continental, onde todos os países estariam subordinados a uma série de decisões e interesses vindos de Washington ou de Berlim. Nessa nova etapa, a única forma dos Estados Unidos garantirem sua influência sobre os países do continente seria a vitória sobre o fascismo no continente com o estabelecimento de uma autarquia comandada por Washington. Daí, o fim dos estados nacionais com a abertura e o desenvolvimento de áreas de influência dos Estados Unidos. Comenta Pedrosa: "O imperialismo ianque pode (...) reformar a economia desses países de modo a transformá-las em uma simples economia complementar adaptada ao aparato produtivo e militar da nação-proprietária. Isso não ocorrerá sem o tipo de 'intervenção cirúrgica' que Hitler aplica na Europa."181

Sua análise foi circunstancial e não contava, até aquele momento, com a possibilidade da derrota de Hitler. Entrementes, ela apontava a dependência dos países latino-americanos e a consolidação das áreas de hegemonia dos Estados Unidos. A tendência histórica descrita por Pedrosa veio a se confirmar. Ele anteviu a ação das novas potências mundiais, a saber: os Estados Unidos e a URSS, no pós-guerra. Entre o final da década de 1930 e início da década de 1940, a expectativa de formação de uma aliança de classes em prol da constituição de um Estado nacional independente e de uma independência econômica nacional mostrava-se irrealizável, pois não havia perspectiva de uma intervenção política orquestrada pela burguesia. Seu papel histórico de classe estava esgotado e a solução mais fácil dava-se pela sua subordinação à nova ordem do capitalismo americano ou germânico. Sem dúvida, estávamos diante da confirmação do caráter retardatário das políticas nacionalistas no continente latino-americano.

Pedrosa acreditava que a formação desse novo imperialismo, que excedia em proporções nunca antes vistas as velhas disputas dos países capitalistas no começo do século $\mathrm{XX}$, forçava o fenecimento das fronteiras nos países periféricos e abria - como sua negação consumada - uma perspectiva nova de causa comum entre os povos oprimidos pela nova ordem. Como contraponto a essa situação, não seria mais a burguesia nacional a grande responsável pela transformação social, mas os deserdados da terra que em sua nova atuação histórica dariam a palavra final de combate ao

\footnotetext{
${ }^{181}$ PEDROSA, M. Op. cit., p. 191.
} 
imperialismo. Diz Pedrosa: “Os continentes estão sendo 'totalitarizados', quer queira quer não. Profundas e irresistíveis necessidades econômicas arrebatam com uma força cega as velhas fronteiras nacionais. Esta formidável simplificação da geografia está sendo concluída, na falta de uma ação da classe trabalhadora internacional, sob a proteção tempestuosa da contra-revolução permanente do imperialismo. (...) Os escravos coloniais daqui em diante não terão fronteiras arcaicas dividindo-os; eles então terão a consciência de ser, em cada hemisfério, um único povo oprimido."182 À primeira vista, o artigo de Pedrosa fecha questão sobre as condições criadas pela nova ordem mundial, que não se traduzem em um processo infalível e inevitável de transformação socialista.

A expectativa de transformação revolucionária não era dada apenas pelas condições objetivas e contraditórias do imperialismo, mas dependia também da ação consciente da classe trabalhadora. O que é interessante notar é que por mais que o processo de transformação não fosse infalível, a nova ordem por si colaborava com a formação de consciência dos povos. Conclui Pedrosa: "Uma vez que os latifundiários e a burguesia da América Latina tenham se arruinado, não restará nada mais a eles do que baixar suas cabeças sob o jugo do novo conquistador. A tarefa (dos trabalhadores, camponeses e intelectuais) será unificar as Américas na fraternidade proletária e reconstruir seu Novo Mundo sobre as pedras de fundação da paz e do socialismo. Mas esta grande revolução apenas pode ser completada com a colaboração da classe trabalhadora americana." ${ }^{183}$ Em lugar das burguesias nacionais, os trabalhadores, os camponeses e os intelectuais convertiam-se nos responsáveis pelo destino da América Latina, apenas e tão somente se esse processo fosse realmente internacional e contasse com participação de todos os explorados na formação de um novo mundo.

O que balizou o interesse renovado dos Estados Unidos pela cultura da América Latina foi a tentativa de suprimir a influência dos modelos e das tradições européias e, sobretudo, alemãs no Continente. A palavra de ordem passou a ser a investigação das tradições culturais das Américas. Isso significava, por um lado, creditar valor aos ideais de liberdade e de democracia norte-americanos e condenar o nacionalismo 'dos outros' países, e por outro, valorizar a diversidade étnica e cultural do continente americano em franca oposição ao critério racial nazi-fascista. Tacuchian salienta a opção da política de

\footnotetext{
182 PEDROSA, M. "What next in Latin America" In New International, New York, outubro de 1940, p. 191.

${ }^{183}$ Idem, ibidem, p. 191. (parênteses nossos).
} 
Roosevelt pela cultura das Américas: "O encaminhamento das propostas apresentadas durante o conclave (da Divisão de Relações Culturais do Departamento de Estado) revela o interesse do governo norte-americano pela cultura da América Latina, (...) e um compromisso de envolvimento do governo federal no processo, chamando a si a tarefa de estimular o intercâmbio entre os países americanos. O tom geral dos discursos referese à transferência de interesse cultural, antes centrado na Europa e agora declaradamente voltado para os países do sul. (...) A tônica das discussões girava em torno da idéia de "cooperação" e "integração" dos povos americanos, da necessidade de deslocamento do movimento cultural para o sentido norte-sul, ao invés do tradicional movimento do leste (Europa) para o oeste (EUA) e, por outro lado, reconhecia-se o imenso desconhecimento entre os países do Hemisfério Ocidental." ${ }^{184}$

Até pelo menos 1943, quando o destino da Alemanha nazista pareceu estar consumado, as relações políticas e econômicas dos Estados Unidos com a América Latina foram consideradas prioritárias e, de fato, possibilitaram o desenvolvimento e a ampliação hegemônica da cultura, da indústria e da economia norte-americanas no mundo do Pós-Guerra. Por isso, o intercâmbio e a política cultural dos Estados Unidos para o continente americano estiveram ligados de forma invariável às estratégias políticas internacionais e às atividades propagandistas. Tacuchian diz: "O centro das decisões permaneceu no Departamento de Estado, pois as ações panamericanas envolviam relações diplomáticas internacionais. O Departamento controlava e exercia poder de veto sobre as propostas lançadas por outras agências (entre elas, a União Panamericana). Outro braço do programa era o OCIAA (...), agência emergencial formada para responder aos desafios gerados pela situação de guerra, e apesar de voltado primordialmente para a formulação de um programa econômico estratégico para o Hemisfério, tinha nas atividades culturais uma base de sustentação para a reformulação das mentalidades. Neste contexto, em que a política cultural e a propaganda mesclavam-se, o programa (artístico) (...) foi formulado com a finalidade de envolver a comunidade intelectual norte-americana na sua totalidade, abrangendo diferentes associações representativas de setores diversos, tais como o de educadores,

\footnotetext{
${ }^{184}$ TACUCHIAN, M. de F. G. Panamericanismo, propaganda e música erudita: Estados Unidos e o Brasil (1939-1948). Tese de doutorado apresentada ao Departamento de História da Faculdade de Filosofia, Letras e Ciências Humanas da Universidade de São Paulo. Orientador: Prof. Dr. Arnaldo Daraya Contier. 1998, p. 46. (parênteses nossos).
} 
musicólogos, artistas, orquestras, universidades, associações cívico-comunitárias e mesmo esferas governamentais ligadas à cultura, como a Biblioteca do Congresso."185

\section{A missão cultural norte-americana e Cândido Portinari}

As atividades culturais eram eficazes na persuasão e na construção de uma imagem positiva dos Estados Unidos e de sua política no Brasil. Por diversos meios, a Política da Boa Vizinhança se efetivava: a publicação de artigos e de reportagens completas em jornais e revistas norte-americanos sobre o Brasil e várias de suas personalidades; a difusão de programas da NBS, da CBS e de outras companhias radiofônicas, falados em português e voltados para o público brasileiro; a organização de expedições culturais de escritores, cineastas e artistas norte-americanos para conhecer o Brasil e sua cultura; a concessão de verbas para a ida dos artistas brasileiros consagrados para os Estados Unidos. A instituição que teve mais influência na execução dessas tarefas foi, sem dúvida, a OCIAA. Antônio Pedro Tota comenta: "A agência criada por Roosevelt e dirigida pelo magnata Nelson Rockfeller tinha (...) duas importantes incumbências: difundir entre os americanos uma imagem positiva dos países latino-americanos, em especial do Brasil, e convencer os brasileiros de que os Estados Unidos sempre foram amigos do Brasil. Essas foram as tarefas levadas a cabo pelos meios de comunicação de massa, que se consolidavam nos anos 40."186

O grande evento que marcou o início da aproximação cultural entre o Brasil e os Estados Unidos foi a Feira Mundial de Nova York em 30 de abril de 1939. Nela, o

\footnotetext{
185 Idem, ibidem, pp. 48-49. (parênteses nossos). Tacuchian descreve a estratégia político-cultural norteamericana para a América Latina nos seguintes termos: “As iniciativas (culturais) (...) foram incluídas na categoria das estratégias da 'guerra psicológica', complementando as iniciativas da 'guerra econômica'. (Envolvendo todos os setores da sociedade norte-americana), veiculando mensagens de reforço aos ideais de 'democracia' e 'liberdade'. (No caso da música), (...) artistas profissionais e amadores engajaram-se nos esforços de guerra, cantando, tocando ou compondo e publicando obras cívicas e patrióticas, trabalhando diretamente no "front" ou realizando turnês de concertos no país ou no exterior (...). (E conclui Tacuchian) no envolvimento da guerra (grande parte da intelectualidade e dos artistas norteamericanos) assumiram também o papel de "bons vizinhos"”. Idem, ibidem, p. 49. (parênteses nossos). Tota demonstra a perspicácia de Rockefeller em perceber a relação necessária que se deveria estabelecer entre o comércio norte-americano na América Latina e a promoção de um novo estilo de vida: "O serviço de informação de Rockefeller revelou, num relatório de 1941, que vários negócios americanos eram representados na América Latina por alemães e/ou simpatizantes do nazismo. Ironicamente, esses representantes usavam os anúncios e a propaganda das empresas para a difusão, ainda que velada, de mensagens antiamericanas. Nelson acreditava que o futuro dos empreendimentos na América Latina dependia da venda não só de produtos americanos, mas também do modo de vida americano." TOTA, A. P. O imperialismo sedutor: a americanização do Brasil na época da Segunda Guerra. São Paulo: Companhia das Letras, 2000, p. 54.

${ }^{186}$ Idem, ibidem, p. 93.
} 
governo brasileiro montou um pavilhão com tudo o que caracterizava o país naquele momento e lá foram expostos desde produtos de interesse para venda até símbolos de modernidade e obras da cultura brasileira. Tota diz: "A New York World's Fair abriu suas portas (...). Uma imensa vitrine de sofisticadas bugigangas foi apresentada para visitantes do mundo todo. Os brasileiros que (...) visitaram a Feira, ou que consultaram jornais e revistas, mal puderam conter a admiração. Ficaram atônitos diante de aparelhos de barbear, máquinas de lavar roupas, primitivos aparelhos de televisão e robôs. (...) O Brasil, assim como vários outros países, participou da (...) (Feira). O pavilhão brasileiro foi projetado por Lúcio Costa e Oscar Niemeyer. E, no lançamento da pedra fundamental do edifício, ouviu-se o discurso do ministro da Indústria, Comércio e Trabalho, dr. Waldemar Falcão, transmitido em ondas curtas do Brasil para os Estados Unidos. (...) Uma banda tocou o Hino Nacional. Logo a seguir, o discurso do ministro brasileiro enaltecia a Política da Boa Vizinhança, '[...] tão preconizada pelos presidentes Roosevelt e Getúlio Vargas [...]",. ${ }^{187}$

Nas artes plásticas, Cândido Portinari foi escolhido para representar o Brasil nos Estados Unidos e preparou três obras para a Feira: "Jangadas do Nordeste", "Cena Gaúcha" e "Festa de São João". Embora o Pintor tivesse recebido apoio entusiástico de intelectuais ligados ao Ministério da Educação, tais como Carlos Drummond de Andrade e Mário de Andrade, o círculo mais próximo do ministro Gustavo Capanema e também grande parte do meio artístico brasileiro manifestaram-se contra a escolha dele como expoente da arte brasileira. ${ }^{188}$ A acusação de que Portinari era favorecido pelo

\footnotetext{
${ }^{187}$ TOTA, A. P. Op. cit., pp. 94-96. (parênteses nossos).

188 Em fins de 1930 e início de 1940, muitos intelectuais e artistas ligados ao modernis mo brasileiro colaboraram com a política cultural do Ministério da Educação. Simon Schwartzman relata os motivos da aproximação que o governo brasileiro fez com os modernistas: "Era necessário desenvolver a alta cultura do país, sua arte, sua música, suas letras; era necessário ter uma ação sobre os jovens e sobre as mulheres que garantisse o compromisso dos primeiros com os valores da nação que se construía, e o lugar das segundas na preservação de suas instituições básicas; era preciso, finalmente, impedir que a nacionalidade, ainda em fase tão incipiente de construção, fosse ameaçada por agentes abertos ou ocultos de outras culturas, outras ideologias e nações. (...) Este projeto ambicioso (do Estado Novo) só explica em parte, no entanto, a preocupação do ministro com as atividades de tipo cultural e artístico. Uma outra parte, talvez mais importante, deve ser creditada a suas vinculações de origem com a intelectualidade mineira e, particularmente, com alguns expoentes principais do movimento modernista, vinculações mantidas e constantemente realimentadas por seu chefe-de-gabinete, Carlos Drummond de Andrade." SCHWARTZMAN, S. Tempos de Capanema. Rio de Janeiro: Paz \& Terra; São Paulo: EDUSP, 1984, p.79. Tanto Drummond como Mário de Andrade tinham suas concepções próprias de nacionalismo, que estavam em posição diametralmente oposta à concepção do Ministério da Educação. Criava-se uma disputa entre visões e mentalidades sobre o projeto brasileiro. Simon Schwartzman insiste que a atuação do Ministério para a formação de mentalidades obrigou Capanema a "compor, transigir ou enfrentar" setores mais proeminentes da intelectualidade e da vida artística brasileira: "Não era uma relação tão fácil quanto se imagina. Não há nada que revele, nos documentos e escritos do ministro, que ele se identificasse com os objetivos mais profundos do movimento modernista (...). (E Schwartzman comenta a
} 
Ministério da Educação era tema de polêmicas desde pelo menos 1935 e causou muito desconforto para o Ministro Capanema, que tentou até mesmo vetar, sem sucesso, a indicação do Pintor para a missão cultural nos Estados Unidos. ${ }^{189}$ Além disso, era boato corrente no círculo Capanema que as figuras deformadas, as mãos e os pés dos brasileiros pintados por Portinari, difundiriam uma imagem ruim do País. O impasse a bem dizer foi resolvido fora do País, pois Portinari era conhecido nos Estados Unidos e seu nome fora aprovado por Robert C. Smith, Alfred Barr Jr. e Florence Horn. ${ }^{190}$ Todos

concepção de Mário de Andrade sobre o nacionalismo): na perspectiva de Mário de Andrade, buscava uma retomada das raízes da nacionalidade brasileira, que permitisse uma superação dos artificialismos e formalismos da cultura erudita superficial e empostada. "Enquanto o brasileiro não se abrasileirar", escrevia Mário a Carlos Drummond em 1925, "é um selvagem. Os tupis das suas tabas eram mais civilizados que nós nas nossas casas de Belo horizonte e São Paulo. Por uma simples razão: não há Civilização. Há civilizações. Cada uma se orienta conforme as necessidades e ideais de uma raça, dum meio e dum tempo. (...) Nós, imitando ou repetindo a civilização francesa, ou a alemã, somos uns primitivos, porque estamos ainda na fase do mimetismo." SCHWARTZMAN, S. Op. cit. p. 79-80. Ainda que houvesse uma relação conflituosa entre modernistas e o Estado Novo, a cooptação de alguns deles para trabalhar junto ao ministro Gustavo Capanema deslindou até que ponto a estética modernista fora inócua ou assimilada pela política cultural do Ministério da Educação. Schwartzman expõe a falta de força dos projetos alternativos para se imporem frente à política cultural de Capanema: “(O que Mário de Andrade propunha) era um projeto revolucionário em seus objetivos. Mas o modernismo, do qual Mário de Andrade foi um dos principais representantes, era suficientemente amplo e ambíguo para permitir interpretações bastante variadas, e não se colocar em contradição frontal com o programa político e ideológico do Ministério da Educação. Em algumas versões, o modernismo se aproximaria perigosamente do irracionalismo nacionalista e autoritário europeu, e não é por acaso que o próprio Plínio Salgado seja identificado com uma das vertentes desse movimento. O que preponderou no autoritarismo brasileiro, no entanto, não foi uma busca das raízes mais populares e vitais do povo, que caracterizava a preocupação de Mário de Andrade, e sim a tentativa de fazer do catolicismo tradicional e do culto dos símbolos e líderes da pátria a base mítica do Estado forte que se tratava de constituir." Continua Schwartzman: "Capanema estava, seguramente, mais identificado com esta vertente do que com a representada pelo autor de Macunaíma (...). Era sem dúvida no envolvimento dos modernistas com o folclore, as artes, e particularmente com a poesia e as artes plásticas, que residia o ponto de contato entre eles e o ministério. Para o ministro, importavam os valores estéticos e a proximidade com a cultura; para os intelectuais, o Ministério da Educação abria a possibilidade de um espaço de desenvolvimento de seu trabalho, a partir do qual supunham que poderia ser contrabandeado, por assim dizer, o conteúdo revolucionário mais amplo que acreditavam que suas obras poderiam trazer." Idem, ibidem, pp. 80-81.

${ }^{189}$ O escritor Luiz Martins foi um dos que questionaram a proteção "oficial" do pintor Portinari e dos que reclamaram mais visibilidade para outros artistas plásticos brasileiros, tais como: Di Cavalcanti e Flávio de Carvalho. Para um estudo mais apurado sobre o caráter "oficial" da pintura de Portinari ver: FABRIS, A. T. Portinari: Pintor social. São Paulo: EDUSP \& Perspectiva, 1990, pp. 25-40 e 73-140. Para Annateresa Fabris, Portinari participou de vários projetos ligados ao governo de Getúlio Vargas, mas não foi cooptado pela ideologia populista. A tese central do livro de Fabris é que Portinari não era um pintor oficial do Estado Novo e que sua temática social possuía elementos de uma crítica profunda da sociedade brasileira. Como exemplo, Fabris alude à recorrente representação do proletário, do negro e do retirante nas telas de Portinari. Ao discutir uma das temáticas centrais de Portinari, Fabris propõe: "Poderá parecer difícil, à primeira vista, a dissolução da equação Portinari = pintor oficial. É justamente nesse quadro, no entanto, que está a chave para uma outra leitura do artista de Brodósqui, pois a temática do trabalho nada significa por si só, dissociada do modo pelo qual é tratada. E o tratamento que Portinari dá ao tema desmente a visão oficialista. (...) Se o tema é o trabalho (...), através dele, Portinari denuncia a falsa eqüidade do pacto populista. Nos discursos de Getúlio Vargas, todas as categorias sociais são consideradas igualmente trabalhadoras. Nos painéis de Portinari, aparece uma única categoria de trabalhadores: a massa marginal, o proletário. Rompe-se, portanto, o pacto capital/trabalho, na medida em que o negro é alçado a símbolo do trabalhador braçal brasileiro. Idem, ibidem, pp. 124-125.

${ }^{190}$ Robert C. Smith foi brasilianista, diretor assistente da Fundação Hispânica e muito interessado na obra de Portinari; Alfred Barr foi diretor do Museu de Arte Moderna de Nova York e comprou o quadro 
eles viam muita proximidade entre o realismo social norte-americano e a pintura de Portinari - o que caracterizava a tendência artística realista do Continente Americano em oposição à arte de vanguarda européia - com a diferença de que as obras de Portinari tratava m de mostrar a realidade brasileira, a nação ainda pouco desenvolvida e as camadas populares, o campesino e o trabalhador. Sem ter a intenção de fazer propaganda para o Estado Novo e sem conter uma mensagem política direta e revolucionária como os Muralistas Mexicanos, Portinari se adequava muito bem ao gosto do governo norte-americano. Ele tinha muita semelhança estética com as obras dos artistas da FAP, que em geral, promoviam o lema - o "trabalho reconstrói a nação" - e os feitos do governo Roosevelt.

No mês de junho de 1939, depois que se realizou a exposição "Arte Americana Hoje", ficou decidido que se deveria promover uma exposição de arte contemporânea latino-americana no Museu Riverside em Nova York, como atividade paralela à Feira Mundial de Nova York. Vários países latino-americanos e o Brasil enviaram obras para a exposição. Porém, a seção brasileira não contava com as obras de Portinari. Imediatamente, quem tomou a palavra em defesa de Portinari não foi ninguém menos que Henry Agard Wallace, então secretário da agricultura do WPA, presidente da comissão da New York World's Fair e futuro vice-presidente dos Estados Unidos. Wallace disse: “(para os visitantes que foram ver a seleção de arte do hemisfério, a exibição trouxe uma grande decepção) (...) a decepção foi a seção brasileira, que parecia ter sido escolhida por um 'barman' míope, e consistia quase que exclusivamente em pálidas imitações do academismo europeu. Que uma arte nativa de vigor considerável estava se formando no Brasil, os visitantes da Feira Mundial já haviam percebido, através dos painéis do pavilhão brasileiro, pintados pelo popular e rechonchudo Cândido Portinari, do Rio de Janeiro. Não havia nada dele na mostra."191

O "equívoco" das autoridades brasileiras seria corrigido na inauguração oficial do edifício do pavilhão brasileiro em 7 de setembro de 1939. Tota descreve: "Numa foto publicada no relatório elaborado pelo comissário-geral (Armando Vidal), (...) aparece Cândido Portinari (...). (E Tota comenta a passagem de Portinari pelos Estados Unidos:) Além da música, a pintura e a fotografia representavam uma outra face do Brasil nos

\footnotetext{
"Morro", em 1939, para exibi-lo na exposição daquele mesmo ano, intitulada "A arte de nosso tempo"; Florence Horn foi jornalista da revista Fortune e responsável por uma série de artigos sobre o Brasil, encomendados pelo governo norte-americano e publicados pela revista Time.

191 Cândido Portinari. Catálogo raisonné. Projeto Portinari; diretor, João Candido Portinari. Rio de Janeiro: Projeto Portinari, 2003, Volume 5, p. 228. Cf. Também WALLACE, H. A. "Art of the Americas" In Time, New York, 12 de junho de 1939, pp. 36-37.
} 
museus americanos. Portinari, cujos quadros foram expostos no MOMA, mostrou um Brasil que muitos americanos não conheciam. Um suplemento em rotogravura de $O$ Estado de S. Paulo registrou, numa reportagem fotográfica a inauguração da exposição de Portinari em Nova York. O próprio pintor compareceu ao vernissage, realizado em fins de 1940. Antes, John Jay Whitney, o importante colaborador de Rockefeller, ofereceu um jantar no grã-fino restaurante 21, ao qual compareceram Portinari, Armando Vidal - que estava encerrando as atividades do pavilhão brasileiro na feira de Nova York - e personalidades americanas. Portinari, prestigiado na terra do Tio Sam, voltou aos Estados Unidos em meados de 1941. Três de seus murais podem ser vistos numa seção da Biblioteca do Congresso, confusamente chamada Hispanic Division." ${ }^{192}$

Simultaneamente aos esforços do governo em promover o ingresso dos Estados Unidos no rol dos centros difusores de cultura para a América Latina, que culminaram com a Feira Mundial de Nova York, ocorria a adesão de grande parte da intelectualidade e da comunidade de artistas norte-americanos à política oficial da administração Roosevelt. Se os Estados Unidos estavam preocupados em exercer influência duradoura no Continente Americano só poderiam conquistá-la através da criação de bases culturais sólidas, que tornassem o american way of life padrão a ser seguido pela maioria dos países latino-americanos. Com o tempo - logo após o final do conflito mundial - essa política ganhou força geográfica generalizadora e se estabeleceu internacionalmente. O sucesso inicial da empresa governamental no âmbito das trocas culturais com os demais países das Américas e a tomada de posição política de intelectuais e de artistas se deram no momento em que Paris foi invadida pelas tropas alemãs no dia 14 de junho de 1940. Para muitos intelectuais norte-americanos, entre eles, Archibald MacLeish, ${ }^{193}$ apenas os Estados Unidos com seus valores de liberdade e de democracia poderiam defender a civilização ocidental contra a barbárie nazista, por isso era necessário apoiar a nova política norte-americana para o mundo.

Serge Guilbaut expõe qual era a questão candente para os intelectuais norteamericanos durante a queda da França: engajar-se na luta contra o fascismo ou não? E, mais ainda, de que modo seria possível isso? MacLeish era o porta-voz daqueles que condenavam a conivência com a política de neutralidade defendida pelo governo norteamericano sob pressão dos Republicanos. Diz Guilbaut: "Em 18 de maio de 1940, a

\footnotetext{
192 TOTA, A. P. Op. cit., pp. 97 e 106-107. (parênteses nossos).

193 Como bibliotecário-chefe da Biblioteca do Congresso em Washington, Archibald MacLeish convidou Cândido Portinari para pintar três murais nas paredes da seção hispânica daquela biblioteca.
} 
edição do Nation trouxe um artigo intitulado "Os Irresponsáveis" de Archibald MacLeish. MacLeish não era revolucionário, embora o partido comunista americano o tivesse cortejado durante a Depressão depois da publicação de sua carta aberta "Aos homens jovens de Wall Street". Ela continha um ataque contra a corrupção e a desigualdade e urgia que esses males fossem eliminados a fim de salvar o capitalismo, na opinião de MacLeish, o único sistema que permitia ao artista suficiente liberdade para desenvolver inteiramente seu talento. (Em seu artigo, Macleish fez um ataque virulento ao) (...) silêncio dos intelectuais americanos em face da guerra na Europa provocou uma longa série de polêmicas nas quais o Nation, a New Republic, e a Partisan Review tentaram definir o papel do artista e do intelectual em tempo de guerra." 194

Como Librarian da Biblioteca do Congresso, nomeado por Roosevelt, e em consonância com a Política da Boa Vizinhança, MacLeish convidou Cândido Portinari para pintar os murais da Fundação Hispânica. Embora tivesse se interessado pela arte de vanguarda européia, sua posição em 1940 seguiu mais de perto a de Hoger Cahill: MacLeish defendia o Realismo Democrático, e por semelhança Portinari, como expressão inovadora e legítima da arte nas Américas. Na política, MacLeish propunha que se formasse uma nova "frente popular" nos Estados Unidos, sem conotação política, para apoiar a entrada da nação norte-americana na guerra e para integrar os esforços de guerra contra o nazismo. Um vale-tudo em nome tanto da salvação da cultura contra a barbárie como do apoio à política internacionalista norte-americana. Segundo Guilbaut, Dwight Macdonald compreendeu muito bem o que a proposta de MacLeish encobria, isto é: a defesa de uma arte nacional norte-americana: "Por baixo da bandeira da defesa nacional, estas teses (a de MacLeish e a de Brooks) atacavam o modernismo internacional e defendiam uma arte nacionalista agressiva. (MacLeish e Brooks) atacavam o nacionalismo nazista em nome do nacionalismo americano. De acordo com Macdonald e os remanescentes leais da esquerda independente tais como Farrell, a solução proposta era tão perigosa quanto o que ela atacava. Ambas as versões de nacionalismo apelavam ao artista para que desistisse inteiramente de seu papel crítico e se tornasse uma peça na maquinaria da política."195

\footnotetext{
194 GUILBAUT, S. How New York stole the idea of the modern art - abstract expressionism, freedom, and the cold war. Chicago: The University of Chicago Press, 1985, p. 52. (parênteses nossos).

195 Idem, ibidem, p. 54. (parênteses nossos). Os irresponsáveis eram os intelectuais e militantes de esquerda anti-stalinista que não foram cooptados pela política internacional norte-americana. Macdonald diz: "Aqui nós temos aquela aproximação oficial com a cultura que se espraiou para além dos confins do
} 


\section{$\underline{\text { Os murais de Portinari em Washington }}$}

Mário Pedrosa permaneceu em Nova York até sua expulsão do Secretariado Executivo da IV Internacional em 1940. No ano seguinte, ele tentou retornar ao Brasil, depois de ter viajado por cinco países da América do Sul: Peru, Bolívia, Chile, Argentina e Uruguai. Nesses países travou contato com militantes trotskistas a fim de organizar um novo movimento de esquerda ligado à ala dissidente da IV Internacional e próximo das posições dos intelectuais e dos líderes do recém-criado Workers Party (WP). Pedrosa entrou no Brasil pela fronteira do sul e, logo que chegou ao Rio de Janeiro, foi reconhecido e preso. Por intermédio de seu pai, conseguiu sair da cadeia e foi obrigado a viajar imediatamente para os Estados Unidos, onde passou a residir em Washington. Ali, ele fez contato com Leo S. Rowe, diretor geral da organização internacional União Pan-americana. Por sua vez, Rowe contratou-o para trabalhar como colaborador do Boletim da União Pan-americana, em sua versão dedicada à cultura e às artes e publicada em língua portuguesa. ${ }^{196}$

No Boletim da União Panamericana são conhecidos três ensaios seus: um sobre o pintor Cândido Portinari, publicado em fevereiro de 1942; outro sobre a coleção Widener da Galeria Nacional de Artes dos Estados Unidos e outro ainda sobre o compositor Camargo Guarnieri, ambos publicados em 1943. A partir daí, Pedrosa pôde voltar sua atenção para as artes plásticas, oito anos depois de seu ensaio "Impressões de Portinari" de 1934. O novo ensaio sobre o pintor brasileiro foi intitulado "Portinari - de Brodósqui aos murais de Washington". Ele foi um ajuste de contas com os posicionamentos anteriores de Pedrosa e suas predileções pelo muralismo e pela arte filiada à revolução comunista. Na retomada de sua atividade como crítico de arte, Pedrosa encontraria nova chave interpretativa para a produção artística moderna dos anos subseqüentes. A execução dos murais de Portinari na Biblioteca do Congresso

\footnotetext{
movimento stalinista. A tese de Brooks é essencialmente uma ampliação do ataque aos 'irresponsáveis' feito um ano atrás por Archibald MacLeish, Bibliotecário do Congresso e íntimo da Casa Branca. E não poderia Goebbels, o inimigo da arte moderna 'degenerada', aplaudir não apenas a tendência cultural particular atacada mas também muitos termos do argumento: "Literatura original segue de algum modo o traço biológico; ela favorece o que os psicólogos chamam de 'direção da vida'; ela é uma força de regeneração que de algum modo conduz a raça sobrevivente'. 'Kulturbolschewismus', 'formalismo', 'escrita de círculos sociais', 'irresponsáveis', os termos diferem por razões estratégicas, mas o conteúdo e o Inimigo - é o mesmo." MACDONALD, D. Memoirs of a revolucionist, p. 213 Apud GUILBAUT, S. Op. cit., p. 54.

${ }^{196}$ Cf. PEDROSA, M. Política das artes. (org. Otília Arantes). São Paulo: EDUSP, 1995, pp. 353-354.
} 
oferecia oportunidade de que Pedrosa não somente atualizasse sua compreensão da arte com base nas experiências por ele vividas e nas transformações ocorridas no cenário internacional, mas também propusesse uma nova tendência para a arte brasileira.

No ensaio "Portinari - de Brodósqui aos murais de Washington" de 1942, Mário Pedrosa apresentou uma alternativa possível para a continuidade e o desdobramento do trabalho plástico de Portinari. Um desdobramento inscrito na variedade de pesquisas plásticas realizadas pelo próprio artista. Tratava-se de apontar uma alternativa para o processo recente de instrumentalização das artes, evidenciado no realismo socialista, na arte raciada nazista e no realismo democrático dos Estados Unidos. Pedrosa estava ciente das circunstâncias que levaram o pintor brasileiro a ser escolhido como representante da "Arte Americana". Ainda que houvesse no continente americano uma tendência predominante do realismo, essa se tornava cada vez mais uma imposição para a construção necessária da identidade entre os Estados Unidos e os demais países do continente. Para os intelectuais norte-americanos que mantinham relações estreitas com o governo Roosevelt, as diversas exposições e as pinturas murais de Portinari na Fundação Hispânica funcionavam não só como estreitamento dos laços dos Estados Unidos com o Brasil, mas também como forma de reafirmação e independência dos valores americanos frente à cultura européia.

Ao lembrar das palavras de MacLeish logo depois da inauguração dos murais em 12 de janeiro de 1942, Robert C. Smith comentaria o significado das pinturas de Portinari: "MacLeish declarou em uma carta para sua Excelência, o presidente Getúlio Vargas do Brasil, cujo interesse pessoal foi largamente responsável por tornar possível a viagem de Portinari a Washington, que a Biblioteca 'possuía não apenas pinturas bonitas que ilustravam o campo de interesses da Fundação Hispânica mas também uma altamente original e importante contribuição para a Arte Americana." ${ }^{, 197}$ De modo geral, os escritos de Smith, de MacLeish e de Rockwell Kent enfatizaram o ideal da América unida em torno de ideais de democracia e de respeito mútuo entre os países. Foi nesse mesmo sentido que se afirmou muitas vezes que Portinari pintava as raças colonizadoras do continente (o negro, o índio, o branco) como forma de evidenciar o fato estratégico de que, na América, elas viviam em harmonia e construíam uma nova civilização. A Fortaleza Americana era construída para defesa dos interesses norteamericanos no continente, e os discursos sobre a democracia norte-americana e seu

\footnotetext{
${ }^{197}$ SMITH, R. C. Murals by Cândido Portinari. Washington: The Hispanic Foundation of the Library of Congress, 1943, p. 09.
} 
esforço em estabelecer laços mais duradouros com os demais países americanos encobriam os interesses estratégicos e a atuação política e econômica dos Estados Unidos no continente.

O ensaio de 1942 divide-se em três partes: a primeira trata dos problemas técnicos e estéticos que acompanharam Portinari em toda sua trajetória; a segunda evidencia o momento em que o pintor brasileiro se interessa pela matéria social e se encaminha para expressões plásticas mais coletivas; na última parte, Mário Pedrosa seleciona alguns exemplos e discute como Portinari conseguiu solucionar de forma mais completa a relação entre os problemas técnicos e estéticos em suas obras e alcançou uma expressão menos literária na descrição da realidade. Esse ensaio foi o ponto de transição entre a avaliação de Pedrosa sobre o potencial revolucionário do muralismo e a defesa de uma arte livre. Era preciso fazer um ajuste de suas posições anteriores e lançar um novo caminho a ser trilhado pelas artes. Os murais de Portinari forneciam a ocasião. Visto que o realismo perdera sua função crítica, Pedrosa apontaria o distanciamento propositado das artes tanto do campo das ideologias quanto da produção para as massas como alternativa para que se preservasse o aspecto crítico, a natureza política e a ligação das artes com a revolução social.

Os problemas técnicos enfrentados por Portinari, nas fases decisivas de seu percurso, sempre estiveram acompanhados do problema estético. Essa preocupação constante com a técnica e com o material surgiu como modo de expressar seu realismo psíquico e, pelo menos em parte, por causa de sua formação acadêmica inicial como estudante ligado à Escola Nacional de Belas-Artes. Sob orientação dos professores Lucílio de Albuquerque e Rodolfo Amoedo, Portinari iniciou sua carreira como retratista, o que lhe valeu um prêmio de viagem para a Europa em 1928, com o retrato do poeta e amigo Olegário Mariano. Sua empreitada como pintor surgia pelo curso dos acontecimentos que viveu e pela sua consciência do ofício a cumprir, motivo pelo qual o Pintor foi diversas vezes considerado um verdadeiro trabalhador das artes. Isso explica sua seriedade com os aspectos técnicos da pintura; e Pedrosa diz: "eis por que Portinari nunca em sua vida foi diletante. E assim como os outros aprenderam a ser estucador ou marmorista, ele aprendeu o ofício de pintor. Hoje, um dos traços mais profundos de sua personalidade artística é precisamente esse caráter de artesão, de que nunca se desprendeu."198

\footnotetext{
198 PEDROSA, M. "Portinari - de Brodósqui aos murais de Washington” In Dos murais de Portinari aos espaços de Brasília. (org. Aracy A. Amaral). São Paulo: Editora Perspectiva, 1981, p. 08.
} 
Essa componente das obras de Portinari não interrompeu em momento nenhum o desdobramento incessante de suas descobertas pictóricas, mas transformoutse, com o passar do tempo, no cultivo dos modos de fazer adotados pela arte antiga. Isso não significou apenas a manutenção de sua atividade como retratista ao longo da vida, mas também a procura por soluções plásticas que ele adotou em seus quadros e murais mais arrojados. Da fase inicial marrom até o progressivo interesse pelo homem no meio social, dos murais no MEC até os realizados para a Biblioteca do Congresso em Washington, bem como em sua fase criativa posterior mais livre, houve um processo gradual de adoção de novas formas expressivas coordenado pela técnica pictórica. Se Mário de Andrade não encarou com dificuldade a tentativa conciliatória entre o moderno e o antigo proposta por Portinari, e acabou por nomeá-lo "o mais moderno dos antigos", inserindo-o no grande desenvolvimento do ideal de beleza em curso a partir do Renascimento, o mesmo não se deu com Mário Pedrosa no ensaio de $1942 .{ }^{199}$

${ }^{199}$ É importante notar que, três anos antes da publicação do ensaio de Pedrosa, todo o percurso de Cândido Portinari fora analisado, sob o prisma estético, por Mário de Andrade. Esse ensaio de 1939, cujo título era homônimo ao nome do pintor, constituiu um esforço de compreensão dos mais elaborados e dedicados, até então, à vida e à obra de um pintor brasileiro. Tratava-se de um ensaio em que estavam presentes tanto as idéias que Mário de Andrade tinha sobre a natureza da obra de arte como a cristalização de sua posição nacional no campo artístico. A tentativa de interpretação de Pedrosa dos murais de Portinari, sob nova chave, indicava um acerto de contas também com uma parcela específica da intelectualidade comprometida com os valores da arte moderna brasileira. Mário de Andrade e Portinari compartilhavam um conjunto evidente de princípios ou uma forma comum de entender a essência transformadora da cultura e da arte no final dos anos trinta. Por isso, no esforço de aclarar sua relação com os pressupostos estéticos de Mário de Andrade, Pedrosa empreendeu a análise das obras de Cândido Portinari e tirou delas conclusões novas e destoantes da via atilada pela qual passou e se estabeleceu por muito tempo o modernismo brasileiro. O ensaio de Mário de Andrade sobre Cândido Portinari situava-se na encruzilhada histórica em que se decidia o confronto das ideologias nacionais no Brasil e no mundo. No fatídico ano de 1939, tanto os valores nacionais como o realismo nas artes plásticas serviam menos para a formação de consciência das grandes maiorias do que para a propaganda imperialista e para a promoção e manutenção de regimes políticos. Mário de Andrade não conseguiu encontrar um território livre para a ação que o distanciasse da campanha nacional promovida pelo Estado Novo. Em sua análise da trajetória de Cândido Portinari, Mário insistiu em dois princípios-chave da estética em voga nos anos trinta: as origens do Pintor e a defesa do realismo para a construção de uma imagem nacional. De um lado, a origem campesina de Portinari lhe conferia uma posição diversa da dos outros artistas. Em seu trabalho não se separariam o artesão e o artista. União do estatuto do trabalhador das artes com o do criador de uma nova sensibilidade, união das origens da cultura popular brasileira com o que havia de mais avançado na arte moderna. De outro lado, o veículo escolhido por Portinari era o realismo, em que a consciência particular do pintor e de sua situação no mundo se expressava através dos elementos próprios da 
cultura brasileira. Cândido Portinari era "artista somado a artesão". Nele, o cuidado com a técnica não se transfigurava em um objetivo próprio, mas era parte inerente de um mesmo processo de resolução do problema estético e de "compreensão humana da vida". Diz Mário: "a riqueza prodigiosa (de sua fatura) (...), tal requinte poderia ser muito perigoso si se exercesse por si mesmo, porém (...) Portinari banha a sua cultura de pintor, de uma instintiva humanidade." ANDRADE, M. de. "Cândido Portinari" In O baile das quatro artes. São Paulo: Livraria Martins Editora, c. 1945, p. 106. (parênteses nossos). Essa produção de soluções plásticas, para os problemas de ordem técnica, de estética e de concepção de mundo, baseava-se em caminhos trilhados pela vanguarda artística e também pela arte de combate. No entanto, nenhuma dessas descobertas plásticas, já estabelecidas, exercia influência decisiva no desenvolvimento de sua expressão. Ao contrário disso, Portinari as refazia uma a uma, porque seu trabalho obedecia em primeira instância ao desenvolvimento de sua própria experiência plástica. Isso explica, em parte, uma das características principais de toda a obra do Pintor, que sempre foi muito afeito à apropriação de várias descobertas plásticas sem se fixar em uma específica ou segui-la em tudo. Para Mário de Andrade, isso não resultava menos de sua vivência do problema plástico, a partir do conjunto de sua produção, do que de sua compreensão da vida e de seu nacionalismo. Essas características aliadas eram a motivação da crítica à prática irrestrita do cubismo e do abstracionismo, como modelos puramente analíticos na pintura, e também da desaprovação da arte de combate. E elas serviam como ponto de partida para o reconhecimento de uma nova solução plástica, visto que ela tentava resolver seus impasses próprios e marcava seu encontro com a verdade de seu tempo. Diz Mário: "Cândido Portinari refaz a experiência pressentida, conformando-a aos elementos e caracteres que lhe são pessoais, à essencialidade plástica, ao tradicionalismo, ao realismo, ao lirismo, ao nacionalismo tão fortes da sua personalidade." Idem, ibidem, p. 107. O exame das experiências renovadas da vanguarda artística européia fornecia suporte para o encontro da solução plástica brasileira, assim como, a consciência crítica sobre os rumos da arte de combate impelia à defesa de uma concepção mais vasta da função social da arte. Essa descoberta intuitiva elaborada pela pintura de Portinari foi considerada por Mário como a conquista exemplar do ajuste entre forma e conteúdo na arte moderna brasileira. A obra de Portinari revelava a unidade entre a pesquisa plástica moderna e um senso de realidade proveniente de seus estudos da tradição pictórica européia. Houve, desde o princípio de sua atividade artística, a tentativa de conciliação entre uma pintura realista, baseada na figura humana, e as principais pesquisas sobre a forma na arte moderna. Por isso, Mário de Andrade explicou a tentativa de conciliação dessas duas vias paralelas como o interesse pelo desenho, ou pela elaboração da forma como elemento primeiro da composição e do assunto. Se nas composições de Portinari para o Ministério da Educação no Rio de Janeiro sobressaiam nos esboços descrições realísticas do assunto, na execução final elas eram substituídas pela imaginação criadora. Mas ele mesmo chega a um acordo sobre a definição de Portinari: "de tal forma ele funde a ciência antiga de pintura a uma personalidade experimentalista e anti-acadêmica moderna, que se poderá dizer que é o mais moderno dos antigos." Idem, ibidem, pp. 110-111. Assim, a referência à natureza é um dos elementos essenciais para descrição de sua pintura, trata-se de um movimento que parte do realismo visual em direção à forma. Mário de Andrade dizia que a estética realista de Portinari advinha de uma consciência psíquica da realidade ou de um realismo psíquico (esse termo foi empregado no sentido oposto do automatismo psíquico), que se manifestava na função documentária do Brasil e mais ainda pelo conhecimento plástico dos diferentes aspectos de nossa vida e pelo processo 
Enquanto Mário de Andrade avalizou a solução encontrada para a adequação entre a forma de expressão nova e a antiga, com vistas à inclusão satisfatória do tema e, por isso, da figura humana no universo analítico por excelência da pintura moderna, Pedrosa colocava em xeque até que ponto isso era realmente possível. Não que duvidasse da série de tentativas bem-sucedidas de "sínteses fugidias" executadas pelo Pintor, porém Pedrosa questionava se elas não se tornaram apenas uma necessidade inerente à obra de Portinari, que o impelia a uma procura desenfreada de novas soluções plásticas, e se aquela adequação valia como experiência modelar e definitiva para a arte. De um lado, o trabalho plástico de Portinari mantinha o ritmo lento de assimilação das técnicas, de outro, favorecia uma troca permanente das linguagens modernas no intuito de alcançar um equilíbrio plástico entre o antigo e o novo. Por várias vezes, houve a tentativa franca de superação dos problemas técnicos e estéticos que lhe apareciam com a evolução própria de seu trabalho, mas nem sempre os resultados alcançados proporcionaram uma solução de continuidade satisfatória, o que explica por sua vez o impulso inventivo de Portinari focado sempre em nova linguagem e novos modos de expressão. $^{200}$

Pedrosa observou nas superações da fase marrom, nas pinturas sobre Brodósqui e no afastamento da experiência de abstração geométrica dos planos e das dimensões, o início progressivo da substituição da tela pelo muro e pela técnica do afresco. As obras mais arrojadas do Pintor eram resultado do fascínio pelo monumental na figuração e da predileção pelo estudo das condições sociais; "o problema do homem, a realidade do homem é que agora o interessa". ${ }^{201}$ Aqui, Pedrosa retoma, em 1942, quase de forma

de identificação dos elementos formais brasileiros, "a purunga, o baú de lata colorida, a gangorra, o mastro de São João, etc.”. Essa era a função nacional de suas obras, assim como os maiores exemplos dela encontravam-se nos "assuntos-sínteses", nos quais a preocupação documentária é substituída pela apresentação de elementos psíquicos constantes, que são seus temas preferidos: o café, o morro, etc. Dessa forma, o nacionalismo de Portinari não estava fixado no assunto, mas na abordagem psíquica do artista na composição da obra de arte. Mário comenta a realização dos últimos afrescos: "todos respiram uma intimidade nacional profunda. Mas esta intimidade não deriva, nem derivará nunca no artista, de uma realização exteriormente escrava do assunto." Idem, ibidem, p. 113.

${ }^{200}$ Esse impulso derivava, pelo menos em parte, da precária conquista daquele equilíbrio plástico, o que não invalida a afirmação de Mário de Andrade sobre o cerne da pesquisa em Portinari: "a cada nova experiência técnica e a cada fase nova que lhe nasce oriunda de novos problemas estéticos a resolver", ela se alia a uma compreensão humana da vida. Cf. ANDRADE, M. "Cândido Portinari" In O baile das quatro artes. São Paulo: Livraria Martins Editora, c. 1945, pp. 106-107.

${ }^{201}$ PEDROSA, M. "Portinari - de Brodósqui aos murais de Washington" In Dos murais de Portinari aos espaços de Brasília. (org. Aracy A. Amaral). São Paulo: Editora Perspectiva, 1981, p. 11. 
literal, a descrição feita em "Impressões de Portinari", 1934, quando diz: "do destino do homem, (...) o homem de carne e osso, e não como uma forma abstrata. A plástica é agora o seu grande problema técnico. Sua fatura aproxima-se decididamente da maneira da escultura. Seu modelado, idem. É natural. Compreende-se que no momento em que o artista busca sobretudo a corporeidade escultural, seja atraído pelo lado escultural dos problemas plásticos." ${ }^{202}$ Assim, Portinari envolvia-se na pesquisa estética e técnica da deformação das figuras, colocando-as em posição central nas telas, o "Preto da Enxada" e o "Mestiço".

Em "Impressões de Portinari”, Pedrosa depositou grande expectativa na tendência de superação da contradição entre as figuras e os limites da tela no início da fase muralista. Pedrosa considerava a evolução de Portinari como uma abertura definitiva para "a expressão concreta da matéria em todas as suas manifestações". Naquele momento de agitação política no País, de precedência da importância do homem concreto sobre a construção abstrata da forma, o modelado e a monumentalidade ganhavam força insuperável, porque reavivavam como um fator positivo o interesse pela materialidade na obra, a procura do sentido social da arte e a contribuição dessa última para o processo de conscientização das maiorias. Mais uma vez, tratava-se da tentativa de conciliação entre o novo e o antigo e de sua solução no interesse pela técnica do afresco para inauguração de uma nova fase estética, baseada também na figuração. Comenta Pedrosa: "Portinari se encontra agora diante de uma contradição dialética fundamental da maior transcendência: as exigências da matéria social em sua dinâmica complexidade, e os limites técnicos naturais da arte pictórica especificamente burguesa - a pintura a óleo e o quadro de cavalete. É agora o maior de seus problemas como artista.",203

A tendência para o monumental, que era animada pela predominância do realismo, produzia verdadeira contradição entre a manutenção da profundeza de espaço no plano de fundo do quadro, à maneira renascentista de composição, e a importância atribuída em primeiro plano à figura modelada. Essa contradição, que se acentuava na relação entre figura e quadro, era vista como uma fuga proposital do naturalismo e das soluções abstratas. No entanto, Pedrosa tinha consciência da precariedade da solução conseguida nas pinturas imediatamente anteriores à realização dos primeiros murais por

\footnotetext{
202 PEDROSA, M. "Impressões de Portinari” In Acadêmicos e modernos. (org. Otília B. F. Arantes). São Paulo: EDUSP, 1998, p. 158.

${ }^{203}$ PEDROSA, M. Op. cit., p. 160.
} 
Portinari: "Essa contradição porém é inevitável, isto é, dialética. (...) O domínio da matéria, seu modelado vigoroso e preciso (...) a tudo se recorreu para alcançar aquela harmonia precária mas por isso mesmo profundamente dramática, profundamente dialética deste quadro. (...) Portinari está diante, talvez, de um impasse."204 A solução, antevista no ensaio de 1934, era a possibilidade de conciliação entre o modelado das figuras de Portinari e os espaços públicos através dos murais, a qual não representava uma alternativa efetiva, para a relação figura e fundo, fora dos parâmetros da figuração.

Em 1934, Pedrosa acreditava que o muralismo era a expressão mais bem acabada de uma arte humanizadora e uma promessa de síntese plástica, que o pintor brasileiro poderia levar a cabo na transposição de suas obras em tela para o muro. Afinal, suas pinturas já transgrediam a técnica e a maneira de compor o quadro, e também o seu anseio de caracterização do homem concreto evidenciava a insuficiência dos limites do quadro para a monumentalidade das figuras, dando a impressão de que não cabiam no quadro e saltavam para fora dele. Não haveria contradição entre a realização artística de Portinari e a matéria social, pois ambas faziam parte de um mesmo processo. Se Portinari adotasse o mural como expressão artística do "conteúdo social", isso seria a prova definitiva de que ele se comprometera com o processo de síntese plástica e social. Diz Pedrosa: "(pode ser que ele esteja) diante do futuro. A volta à grande arte sintética, presidida pela arquitetura, que foi perdida com o início da era capitalista, anuncia-se. A pintura já marcha para essa integração com o afresco e a pintura mural moderna. Portinari sente esta atração. Como se deu com Rivera, com a escola mexicana. Aliás, a matéria social o espreita."

O ensaio de 1942 não tomou o "conteúdo social" para a defesa explícita e direta de uma posição combativa ou filiada a preceitos político-partidários. Já não se tratava de evidenciar a força plástica, em benefício do "valor extraplástico (social) (que) surgiu assim independente da intenção imediata do artista", ${ }^{206}$ com o intuito de transformar a arte em arma revolucionária, mas de delimitar mais o que na arte caracterizava sua liberdade criativa inerente e resistente à instrumentalização. É com base nesse esforço que Pedrosa perscrutava até que ponto seria possível manter a atividade livre da arte, sem abandonar o passo da transformação social. Em outras palavras, o ensaio de Pedrosa foi uma tentativa sincera de apontar uma via crítica para a arte, que levasse em

\footnotetext{
${ }^{204}$ Idem, ibidem, pp. 160-161.

205 Idem, ibidem, p. 161. (parênteses nossos).

${ }^{206}$ PEDROSA, M. Op. cit., p. 158. (parênteses nossos).
} 
conta todas as modificações ocorridas no mundo. A solução artística passava pela retomada da importância de sua essência cognitiva da realidade, que não podia estar sujeita a restrições externas. Isso significava a retomada do vínculo que a arte mantinha com a realidade, sem estar subordinada inteiramente a ela ou sem que o conteúdo social se tornasse um imperativo artístico.

Pedrosa não tinha predileção por uma estética que se pautava na mera reflexão da realidade. ${ }^{207} \mathrm{~A}$ atividade artística encontrava seu aspecto estético essencial não na descrição de uma cena burguesa, mas como meio de propagação e como depositária da mensagem sobre a revolução social. Por isso, a diferença entre os dois ensaios de Pedrosa consiste em encarar a atividade artística como meio exato de propagação de uma mensagem, no qual a tarefa comunicativa se completava. Não se contestava essa tarefa da arte, mas a concepção da tela como janela. Visto que a relação entre conteúdo e forma revestia-se de uma nova complexidade e que era necessário entender a obra não mais como transposição literal de um conteúdo, o estudo sobre a capacidade da arte em transmitir mensagens deveria ganhar outra conotação. Essa foi a intenção de Pedrosa ao retomar a análise crítica da obra de Portinari, em 1942, com que ele iniciava de certa forma um processo de ultrapassagem da concepção presa à expressão do conteúdo na obra de arte em direção ao estudo atento de suas leis específicas e de sua liberdade formal, na qual o meio de expressão ganhava independência extraordinária, sem negar seu fundamento na sociedade.

Os problemas plásticos tinham levado Portinaria se interessar pelo mural como novo meio de expressão artística. Da mesma forma que para os artistas mexicanos, o mural apresentava-se como veículo eficiente para a expressão de temas sociais. A força comunicadora da pintura mural permitiu que artistas como Diego Rivero, Alfaro Siqueiros e outros conseguissem tratar de temas políticos e sociais que envolviam a sociedade mexicana. Mesmo que isso sirva para mostrar a afinidade de Portinari com o movimento muralista mexicano, não se pode esquecer que Pedrosa diz que não foi a denúncia social através do tema, mas os problemas da falta de adequação satisfatória

\footnotetext{
207 Há um interesse preponderante em "Impressões de Portinari” pela identificação do vínculo entre sociedade e arte, nos termos empregados no ensaio sobre Käthe Kollwitz, isto é, na sua função revolucionária e socializadora. Se, por um lado, Pedrosa negava o estreitamento entre a atividade artística e a realidade, por outro, recuperava os termos desse vínculo. Nesses ensaios, a arte deveria participar das lutas sociais de seu tempo, mas isso não significava de maneira nenhuma apostar em uma estética naturalista pautada na figuração. Daí, o comentário de Pedrosa sobre Portinari: "que ele não é, no fundo da sua personalidade artística, o vulgar retratista a que o querem reduzir (e que o sucesso do seu métier nesse gênero poderia confirmar), demonstra-o esse desrespeito pelo quadro, característico de toda esta fase final." Idem, ibidem, p. 160.
} 
entre a figura e o quadro, o ponto de partida do pintor brasileiro para a pesquisa plástica com as técnicas e a linguagem do mural. Conforme comentário de Pedrosa: "as origens do muralismo mexicano e da experiência no mesmo gênero do pintor brasileiro podem ser não só recusadas no tempo como também de natureza puramente estética. E isso explica perfeitamente por que não basta constatar qualquer relação de dependência cronológica para deduzir que foi por influência direta do movimento muralista do México que Portinari se decidiu também a entrar pelo mesmo caminho."208

A diferença entre Portinari e os muralistas mexicanos residia no modo como ambos chegaram ao mural; um pela via dos problemas técnicos e estéticos e os outros pelo interesse acentuado na mensagem política. Pedrosa esclarece: "De um modo geral se pode dizer que enquanto a escola mexicana se utilizou principalmente dos elementos de deformação caricatural, tirados não somente da experiência nesse sentido da pintura européia moderna, mas de uma grande tradição nacional própria (a caricatura sempre foi no México uma das grandes manifestações de arte popular), o que Portinari utilizou foi principalmente a deformação plástica, maciça, do modelado picassiano. A preferência nos processos de deformação - para a monumentalidade ou a corporeidade maciça num, no artis ta brasileiro, e para a expressividade social no outro, no movimento muralista mexicano - define a força interior que os impeliu à pintura mural, e as finalidades diversas a que visavam.,"209

Em oposição ao percurso analítico da vanguarda européia, nos idos da primeira metade do século XX, a arte moderna nos países americanos pautou-se nas pesquisas de superação das limitações tradicionais do espaço representativo do quadro. Essa tendência surgia em concomitância com a necessidade de atribuição de um novo sentido para as artes e visava, em última instância, a uma nova integração delas. Enquanto a atividade européia deixou como legado um processo de depuração e constituição da pesquisa plástica da forma e da cor no interior da tela, o mural foi a expressão alcançada pela arte no Continente Americano com o intuito de fornecer uma função social mais evidente para a pintura. Daí por que Pedrosa concluía em seu ensaio: "Sem dúvida, foram os artistas mexicanos os primeiros que se utilizaram das experiências novas resultantes das necessidades do alargamento do campo pictórico, num sentido mais amplo, menos limitado ao simples campo de pesquisas técnicas ou estéticas herméticas

\footnotetext{
${ }^{208}$ PEDROSA, M. "Portinari - de Brodósqui aos murais de Washington" In Dos murais de Portinari aos espaços de Brasília. (org. Aracy A. Amaral). São Paulo: Perspectiva, 1981, p. 13.

${ }^{209}$ Idem, ibidem, p. 14.
} 
ou gratuitas. É a sua glória indisputada. Constatando as limitações da pintura de cavalete, eles simplesmente foram às do cabo: puseram de lado a pintura a óleo e se entregaram ao afresco." 210

Por causa desse aspecto, o muralismo seria a expressão não apenas de uma nova forma de se lidar com os avanços da pesquisa plástica, mas também a intenção de ressaltar a capacidade comunicadora da arte. Aliás, esse foi o motivo principal da defesa acentuada dos murais de Portinari por Mário de Andrade e o que explica a solução figurativa como um contraponto da arte brasileira às pesquisas puristas realizadas pelas vanguardas européias. Com isso, Mário de Andrade chegaria a dizer que Portinari tinha se interessado muito pouco pelas soluções plásticas do cubismo e do abstracionismo por causa de seu esforço em preservar o espaço da figura humana nas telas e nos murais sem descartar, porém, em nenhum instante, a pesquisa autônoma da forma. Assim, o escritor brasileiro inseria-se no rol dos intelectuais e artistas americanos que acreditavam na recuperação do sentido social da arte moderna, na medida em que ela reativava sua função comunicadora e empreendia uma aproximação imediatamente eficaz entre o público e a arte. A despeito das diferenças de como Portinari e os pintores mexicanos chegaram ao mural, tanto num como nos outros, a figura tinha muita relevância e era imprescindível para que se manifestasse a contento a potencialidade comunicadora da obra. O que tanto Portinari e os muralistas mexicanos tinham em comum não era apenas a procura, no fim das contas, pelo sentido social na arte, senão também a tentativa de recuperação do assunto na pintura como seu veículo supremo.

Disso se origina o comentário de Mário Pedrosa, em 1942, sobre o conceito de funcionalidade na acepção empregada por Mário de Andrade. Em meio ao desenvolvimento pleno do modernismo no Brasil, o Escritor entendia que os murais de Cândido Portinari eram a síntese plástica do elemento cultural imprescindível para a propagação e o estabelecimento de uma configuração sociocultural legítima, ou ainda, a síntese entre a pesquisa mais avançada da forma artística e a expressão de um conteúdo genuíno sobre as relações sociais existentes, entre a imagem brasileira e a expressão artística internacional. Pedrosa dizia que era possível encontrar na obra de Portinari aquela "funcionalidade nacional” apontada por Mário de Andrade, contudo ela derivava

\footnotetext{
${ }^{210}$ PEDROSA, M. Op. cit., p. 14. Pedrosa continua: "(Cândido Portinari) queria simplesmente, movido por intrínsecas intenções monumentais, poder entregar-se à vontade às experiências de deformação do plástico. E compreendeu que para isso precisava, também, de um conjunto arquitetônico, ao menos de um muro, fora do qual não poderiam ser essas intenções expressas ou satisfatoriamente resolvidas. $\mathrm{O}$ movimento muralista mexicano, entretanto, ao que visava era sobretudo exprimir - na frente estética ou espiritual - os ideais da Revolução Mexicana.” Idem, ibidem, p. 15.
} 
menos da fixação de um elemento cultural e mesmo da alusão à especificidade brasileira do que de uma tentativa de interpretar nossa realidade. Pedrosa comenta: "Recenseando 'as indústrias brasileiras', os afrescos do Ministério da Educação têm o que Mário de Andrade chamou de 'funcionalidade nacional'. Mas nunca se prendem literalmente aos assuntos de cada painel nem visam demonstrar coisa alguma. No fundo, Portinari nunca viu nesses afrescos apenas uma realidade a exprimir, mas antes talvez a interpretar."211

Assim, Pedrosa ressaltava tanto a diferença entre Portinari e o muralismo mexicano como a insuficiência interpretativa do ensaio de Mário de Andrade sobre o pintor brasileiro com o objetivo de apresentar uma nova direção possível para a arte moderna no Brasil e no mundo. Por um lado, Portinari não tinha como respaldo de seus murais a realidade de um movimento revolucionário emergente que levou os pintores mexicanos a se aproximarem da população. Sua opção pelo mural era isolada e não constituía tendência dominante no Brasil. Por outro, Pedrosa enfatizava que a análise de Mário de Andrade sobre o caráter nacional da arte de Portinari e a escolha do pintor pela literalidade no tratamento dos temas desconsiderava a predileção pela liberdade na criação. Diz Pedrosa: "Nos afrescos de Portinari esteve sempre presente, ao lado ou acima da realidade, a finalidade plástica. Ele foge sempre - mesmo quando faz as maiores concessões ao elemento da realidade ou didático, ao qual chama de ilustração. (...) Um dos traços mais característicos da nova tendência é sem dúvida que a reação antinaturalista se acentua. (...) Sente-se opresso pelas contingências do trabalho ciclópico (Ministério da Educação) que realizou, pela insistência dos temas puramente nacionais, ou necessariamente nacionais, pelo medo legítimo de cair nas facilidades da descrição convencional e, sobretudo, pela falta de ressonância ou... ressonância demasiada dos mitos raciais e sociais, isto é, nacionais, que vai criando."212

A tentativa de Pedrosa de analisar a situação atual das artes fazia parte da sua compreensão de que se concretizaria mais cedo ou mais tarde a finalidade suprema da arte moderna como integração e síntese. Pedrosa acreditava em um processo potencial de integração das artes e de síntese entre arte e sociedade, que de certa forma serviu de baliza para o impulso direcionador de sua predileção artística. O ideal de integração das artes e de síntese da arte com a sociedade deveria partir de uma outra noção sobre o significado social da arte com vista a restabelecer a primazia da estética no campo da plástica. Foi assim que ele avalizou e uniu, no entendimento desse processo, o início das

\footnotetext{
${ }^{211}$ PEDROSA, M. Op. cit., p. 15.

212 PEDROSA, M. Op. cit., pp. 16-17.
} 
experiências de superação da tela pelo muro em 1934 e, posteriormente, a feitura dos murais em Washington. Guardadas as devidas diferenças entre as duas fases da obra de Portinari, houve a preocupação comum e a tentativa de confirmar nos acontecimentos plásticos um processo geral de transformação social, de integração e de síntese, responsável pela recuperação do mais alto significado social da arte e da construção de novas bases para o estabelecimento da sociedade moderna.

Antes de qualquer outra função, a arte seria responsável não apenas pela formação de uma nova consciência ampla e crítica para todos, mas também pela gênese do homem do futuro, na qual a função socializadora da arte estava acima de qualquer outro significado que se lhe atribuísse. Desse modo, Pedrosa esboçou uma alternativa viável para o realismo figurativo no ensaio de 1942, com base nas pesquisas analíticas da forma e da cor na pintura elaboradas pelas vanguardas européias, que mantinham relação óbvia e muito próxima com o fenômeno da arquitetura moderna. Certamente, na análise de 1934, o muralismo com sua dependência necessária do assunto não era encarado como pouco adaptado ou mesmo prejudicial à nova arquitetura, mas parecia ser a melhor solução plástica encontrada até aquele momento. Já em 1942, o problema da expressão e da liberdade artística ganham importância, evidenciando uma nova abordagem sobre o problema da comunicação em arte. Esta não se deveria fazer pelos termos tradicionais da transposição literal do conteúdo na obra, às custas da restrição na pesquisa formal. Agrega-se ao problema da variação do significado atribuído à função comunicativa na obra de arte, um interesse maior pelas leis específicas da produção plástica.

Pedrosa analisou e descreveu com minúcia os quatro painéis de Washington: Descoberta, Bandeiras, Catequese e Garimpo. Neles, o objetivo principal dos temas era recontar a história da América e das façanhas de portugueses e de espanhóis. Todo esse trabalho foi feito sem a utilização repetitiva, automática e vazia das soluções plásticas bem sucedidas encontradas nos murais do MEC, o que parecia indicar para o Crítico a abertura de uma nova fase na pintura de Portinari. Por certo, mantinha-se a semelhança em tratar o campo pictórico como uma composição literária, que era desvelada pelo recurso à mensagem ou ao conceito verbal sobre a realidade. Mesmo que o Pintor não visasse demonstrar algo ou não tomasse nada literalmente, a simples recorrência ao assunto evidenciava os limites de seu trabalho e sua rigidez em tentar preservar o nó de uma suposta relação evidente entre a pintura e a realidade. Com isso, a nova fase ainda tentava alcançar aquele equilíbrio frágil entre “o plástico e o abstrato, entre o puro 
pictórico e a vida", que Pedrosa observara como uma constante em toda a trajetória do Pintor; não obstante isso, a liberdade plástica alcançada na feitura dos murais de Washington foi maior.

Dessa forma, iniciava-se uma fase mais livre na criação, com um toque de influência das experiências surrealistas, em que predominava a cor azul. Ela era o resultado de uma série de trabalhos em pintura a óleo realizados pelo Pintor, na mesma época em que ele executava os murais do MEC. Ali, nos painéis e nas telas da Exposição de Nova York, bem como nos murais da Fundação Hispânica na Biblioteca do Congresso em Washington, o artista, "fora de seu país, fora do ambiente natal familiar, sentiu-se menos enraizado, mais livre para entregar-se, sem nenhum empecilho, de nenhuma ordem, ao demônio de sua virtuosidade, de seus recônditos impulsos, de sua inspiração. Jamais, e isso se depreende logo à primeira vista, em nenhum outro momento de suas realizações murais, se sentiu ele mais livre, mais desimpedido, mais disposto a fazer as ginásticas técnicas mais perigosas e as deformações mais violentas. Estas foram composições executadas sob um profundo sentimento interior de liberdade." 213

Cândido Portinari interessara-se pela pesquisa das soluções de uma plástica mais pura e, em particular, pelas experiências do Surrealismo, mas sua referência ao onírico dos surrealistas era muito fraca e a independência de suas imagens e ícones não era tão intensa a ponto de instigar uma difusão e uma profusão simbólica verdadeiras. Para Pedrosa, o que havia de comum entre o pintor brasileiro e os surrealistas era apenas a tendência de não abandonar por completo as referências à figura ou ao tema, que emprestavam significado à produção plástica. Nesse sentido, Portinari entendia a sugestão literária como meio e necessidade complementar da obra, resultando em um afastamento deliberado da pintura abstrata ou da pesquisa plástica totalmente pura. $^{214}$ Feita essa ressalva, Pedrosa apontaria a grande inovação do Pintor - como resultado do que parecia ser sua nova fase - na maior liberdade e criatividade do trabalho plástico e no seu distanciamento dos ícones nacionais ou dos mitos raciais. Por isso, Portinari parecia afastar-se um pouco do realismo figurativo e da predominância excessiva do assunto em seus murais.

Segundo Pedrosa, por um curso diferente, desafeito gradualmente ao estabelecimento do verídico em formas bem-sucedidas, o Pintor evitava a convenção e a

\footnotetext{
${ }^{213}$ PEDROSA, M. Op. cit., p. 19.

${ }^{214}$ PEDROSA, M. Op. cit., pp. 18-20.
} 
ênfase realista das cenas na pintura. Havia um indício nos murais de Washington de que ele trocava a importância e o interesse pelas "contingências externas" por um chamamento à universalidade inscrita na forma. A esse respeito, o Crítico diz: "ele tende ao que se poderia chamar de desmitologização de seus ícones, de suas imagens, de suas paisagens, numa fuga às contingências externas, de meio e de tempo, nacionais ou não". ${ }^{215}$ Isso sinalizava, para o Crítico, a relevância da procura feita pelo Pintor de um novo tipo de harmonia para a composição, na qual se substituía, com "uma sucessão de acordes dissonantes", o equilíbrio e a invariabilidade fácil na representação da realidade para "atingir uma harmonia mais transcendente e silenciosa."216 Tratava-se, nada mais nada menos, da constatação de um sintoma de desvencilhamento progressivo da literaridade na expressão pictórica.

A procura da harmonia mais transcendente e silenciosa derivava do decréscimo no interesse de Portinari pela solução fácil e pela adoção de ícones e de imagens prontas em sua pintura. Para ele, valia cada vez mais a pena fazer um aprofundamento dos problemas da forma para encontrar um tipo inédito de equilíbrio e de organização em toda a composição. Esse esforço do Pintor correspondia a um tratamento diferente dado à forma e à cor. De fato, a figuração mantinha-se de novo como a coluna vertebral dos murais de Washington, porém ela apagava com maior intensidade suas referências exteriores ou a referência naturalista e, com isso, caminhava-se tanto para a despersonalização das figuras como para a criação de espaços ou ambientes sem qualquer referência a lugares verdadeiros. Do mesmo modo, o movimento aproximativo em direção aos valores da cor dava-se não pela tentativa de Portinari em encontrar semelhança do objeto pintado com o efeito da filtragem da luz nos objetos externos, mas pela intensidade de absorção ou difusão das gamas cromáticas na percepção.

Para Pedrosa, dentre os murais da Biblioteca de Washington, o Garimpo parecia ser "o mais livre e mais audacioso". ${ }^{217}$ Nele, o Crítico encontraria um "contraste antinaturalista da luz e das cores (que) toma aqui todas as liberdades. O segredo da composição está em parecer que não existe. As figuras no entanto se arrumam em cruz, ou em $\mathrm{X}$, o que dá a todas uma unidade estrutural quase cósmica, e, ao mesmo tempo, uma força desintegradora extraordinária, pois permite um movimento de rotação que impede as figuras a se projetarem em todas as direções. (...) poderosos acordes

\footnotetext{
${ }^{215}$ Idem, ibidem, p. 19.

${ }^{216}$ Idem, ibidem, p. 20.

217 PEDROSA, M. Op. cit., p. 23.
} 
dissonantes dominam a cacofonia que ameaça irromper do contraste do branco e do preto, do azul e do vermelho.(...) O assunto é mais distante do que nunca."218 Aí, Pedrosa resumia, em uma solução provisória, toda a sua experiência em tantos anos de convívio com pessoas e com as dificuldades envolvidas na produção artística moderna, no Brasil e no mundo. Sem dúvida, a análise sobre aquele painel de Portinari apontava um caminho alternativo para a arte, que não estava em voga desde, no mínimo, o início dos anos trinta.

Como se vê, a tendência de uma arte mais pura parecia estar eclipsada pela ascensão do realismo figurativo. Contudo, Pedrosa assinalava, no que seria a inauguração da nova fase de Portinari, uma solução saudável para as intransigências da literalidade ou da subordinação da pintura ao assunto. Ao que tudo indica, a contradição entre a exigência do assunto e a pesquisa formal somente seria resolvida pelo Pintor na adoção irrestrita da pesquisa pura. Poder-se-ia concluir disso que Pedrosa já afirmava a impossibilidade de conciliar a figuração e a tendência analítica das vanguardas artísticas européias, mas não havia ainda uma defesa incondicional da arte abstrata e sim o apontamento de uma continuidade possível válida como o muralismo para a arte moderna. Por certo, encontrava-se uma "síntese fugidia", um dualismo do puro pictórico e da vida na obra de Portinari, que não seria resolvido sem a independência da plástica e a liberdade maior da pesquisa. Com isso, Pedrosa tentava indicar um novo caminho de pesquisas plásticas e de resultados estéticos para Portinari.

A solução plástica encontrar-se-ia no equilíbrio entre o assunto e o crescente antinaturalismo da forma e da cor. Por conseguinte, o problema da utilização ideológica da arte, através do figurativo, não invalidava ainda e por completo as proposições artísticas de Portinari ou de Rivera, pois o reparo devia ser feito na ênfase realista da figuração. Dado que a solução preponderante sinalizava o afastamento do assunto como justificação unívoca da obra - em benefício das relações estruturais e puras da composição, a chave para a interpretação da obra não poderia utilizar-se da compatibilidade entre o tema e a transposição direta dele para a pintura. Dessa forma, Pedrosa avaliava o painel de Portinari: “A dominante é azul, azul, azul, (...) a dominante é contrabalançada pelos tons verdes do barco, pelo vermelho da camisa de um garimpeiro, pelo cinza, pelo preto e branco das figuras (...) uma figura na composição atrai a atenção: é a de losangos vermelhos (...) os losangos vermelhos do primeiro plano

\footnotetext{
${ }^{218}$ Idem, ibidem, p. 24. (parênteses nossos).
} 
são quase os únicos tons quentes de todo o painel (...) eles chocam sem dúvida alguma a harmonia geral (...) sem esses berrantes vermelhos a ambiência seria outra, seria plácida e homogênea. Muitos haveriam de preferir assim. São evidentemente uma dissonância difícil.,219

A necessidade de Cândido Portinari fazer do painel Garimpo uma representação consistente do tema e do conteúdo social nele envolvidos realizou-se através da inclusão do vermelho e de suas variantes sobre o azul dominante na composição. Sem esses tons, não seria possível ressaltar o drama social da busca ávida pela riqueza e pelo poder, na qual se vêem "possessos metidos em xadrezes, imersos na grande doçura da atmosfera tão diferente, tão estranha à vibração e excitação daqueles bonecos mecanizados, duplamente escravos, do ouro e da sociedade."220 Conclui o Crítico: "sem aquele vermelho e seus derivativos, a própria violência escandalosa dos gestos e mãos escancaradas, dedos cortados, braços destemperados no ar, brandindo uma horrenda massa marrom, não conseguiria destoar, submergida na irresistível melodia dos azuis e cinzas e na trama imponderável de seus matizes. A composição seria 'ouro sobre azul', mas não provocaria nenhum drama plástico.,221

Sem essa dissonância, não se cumpriria a finalidade específica do muralismo, que era "exprimir uma realidade, concreta ou transcendente". Segundo Pedrosa, a tentativa de conciliação do tema com a laboração do valor das cores e da inter-relação estabelecida entre elas revelava aquele problema intrínseco de adequação na obra de Portinari, o que poderia indicar o início de um processo possível de superação do figurativo em prol do abstrato. Contudo, o problema central da adequação entre o drama vivido e o plástico solucionava-se de modo fundamental, também na pintura mural do Pintor, dentro dos limites da criatividade artística ou do domínio exclusivo da plástica. Isso tornava válida a maturidade de expressão conquistada por Portinari em Garimpo e mostrava que não havia apoio indispensável em facilidades ou clichês para a elaboração final da obra. Assim, "a finalidade afinal externa (...) é restaurada sem que ao mesmo tempo o artista caia na banalidade das descrições convencionais, mantendo-se no domínio da pura criação.",222

Anos depois, Mário Pedrosa comentaria - em tom autobiográfico - o início de seu interesse pelas expressões mais livres na arte em confronto com a análise das fases

\footnotetext{
${ }^{219}$ PEDROSA, M. Op. cit., pp. 24-25.

${ }^{220}$ Idem, ibidem, p. 25.

${ }^{221}$ Idem, ibidem, p. 25.

222 PEDROSA, M. Op. cit., p. 25.
} 
de Portinari: "Ele era um artista social por excelência. Com isso queremos dizer que sua inspiração vinha de fora, do convívio cultural, das influências determinantes no momento, dos problemas da época. Sua vocação era "política", não no sentido estrito da palavra, pois nunca foi um político, mesmo quando se candidatou e foi eleito no duro senador pelo PCB, mas num sentido amplo, de gosto, de convivência, de comércio social, de participação. Magnificamente armado artesanalmente, ouvia e gostava de captar idéias e sugestões dos meios intelectuais que apreciava. Aqui, permitam-me, num parêntese, uma nota pessoal: em Washington, durante a guerra, quando Cândido Portinari chegou para pintar os painéis da Biblioteca do Congresso, retomamos a velha camaradagem e o velho papo de outros tempos. Um dia, ele havia acabado o painel dedicado ao ouro do garimpo. Era o painel mais audacioso e expressivo do conjunto e este um dos mais felizes na obra portinaresca."223

Em seguida, Pedrosa discorre sobre sua impressão de que Portinari parecia seguir uma via mais livre e afastada dos excessos da literalidade na pintura. Essa impressão era condizente com os últimos trabalhos apresentados pelo pintor brasileiro em sua curta trajetória nos Estados Unidos, de Nova York a Washington. Contudo, o tempo não veio comprovar essa tendência. Por certo, Portinari interessava-se por retratar em suas obras pessoas simples, temas ligados ao trabalho e à exploração de camponeses e trabalhadores. Entretanto suas obras não tinham um tom político explícito, como se pode ver em alguns murais mexicanos. Diz Pedrosa: “Comentava eu, entusiasticamente, a maneira atrevida com que o pintor reduzia os detalhes figurativos, pé, nariz, cabeça, camisa, peneira, batel, água, pedra, etc., a manchas coloridas, a signos, a formas geométricas como triângulos, por exemplo, para realçar a força plástica significativa do todo, quando ele, com aquele seu jeitão esperto, à caipira, o bonachão, interrompe: " - Pois é, eu aqui me sinto mais livre do que no Brasil. Os literatos me atrapalham'. Ele queria dizer com isso que as idéias forçosamente literárias dos intelectuais amigos interferiam freqüentemente com as suas, ou os seus projetos puramente pictóricos. E ele nunca soube, com efeito, se livrar delas. No princípio de sua carreira, eu também, então seu amigo e freqüentador, me incluo entre aqueles intelectuais.",224

\footnotetext{
${ }^{223}$ PEDROSA, M. "A primeira Bienal” In Mundo, homem, arte em crise. São Paulo: Editora Perspectiva, 1986, pp. 261-262.

${ }^{224}$ PEDROSA, M. Op. cit., p. 262.
} 
Capítulo 3. A tradição moderna no Brasil: Portinari e a crítica de Pedrosa 


\section{$\underline{\text { Fim do Estado Novo - reconfiguração política nacional e internacional }}$}

Com a derrota iminente das potências do Eixo na Segunda Guerra Mundial, a base de sustentação do governo de Getúlio Vargas no Brasil perdeu força e surgiram as primeiras movimentações políticas em favor da abertura democrática. O governo ainda justificava a permanência da ditadura contra as reivindicações democráticas como um imperativo da guerra e dizia, para aplacar os ânimos, que o fim dessa seria também o fim da ditadura. Já em 1943, os estudantes universitários se mobilizaram contra o regime varguista e, no ano seguinte, líderes da oposição liberal se aproveitaram da tibieza e da situação cada vez mais insustentável do governo para lançar a candidatura do major-brigadeiro Eduardo Gomes à Presidência da República. Sem muita alternativa, em 28 de fevereiro de 1945, Vargas cedeu às pressões e assinou documento determinando o prazo final de noventa dias para a realização de eleições gerais. Todavia, Vargas não se deu por vencido: a perda de apoio da cúpula militar na sustentação da ditadura fez com que ele procurasse apoio popular dos movimentos sindicais controlados pelo governo e do Partido Comunista do Brasil.

No momento em que a campanha de Eduardo Gomes e o processo de transição da ditadura para o regime democrático se consolidavam, Vargas tentava conseguir apoio em diversos setores para sua permanência no governo. Edgar Carone diz: "Enquanto a posição de Goes Monteiro, aparentemente, é de respeito ao calendário eleitoral - pois muitos outros militares, como Juarez Távora e Juraci Magalhães, são patrocinadores da candidatura Eduardo Gomes -, Getúlio Vargas manobra em sentido diversionista. Diz acatar o desejo das forças eleitorais, que pôs em funcionamento todo o Código Eleitoral, que marcou a data do pleito para 2 de dezembro. Enquanto isto, manobra em três frentes para retardar ou impedir as soluções existentes. De um lado, joga com elementos oligárquicos de sua confiança - os Fernando Costa ou Benedito Valadares; de outro, incentiva ou canaliza correntes populares contrárias às candidaturas presidenciais; e, afinal, tenta captar as simpatias de Goes Monteiro e de segmentos do Exército. O jogo em três frentes dá-lhe maleabilidade e, ao mesmo tempo, o enfraquece, pois as contradições entre as três correntes é grande e o peso de cada uma, diferente."225

${ }^{225}$ CARONE, E O Estado Novo (1937-1945). Rio de Janeiro, São Paulo: Difel, 1976, p. 331. 
As manifestações públicas em favor da permanência de Vargas no governo deram expectativa de sobrevida à ditadura do Estado Novo. O "Queremismo" se beneficiou como movimento político do prestígio que Vargas desfrutava entre as massas populares: “(...), com elas, sua ação tem caráter diferente, fato que assusta seus parceiros. O movimento queremista (palavra derivada da expressão "Queremos Getúlio”) defende a palavra de ordem, Getúlio Vargas com Constituinte, e nasce em fins de junho, porém sua origem primeira é o movimento das panelas vazias, de março de 1945. Os operários que percorrem a capital paulista para atacarem os comícios antiEstado Novo, ou para gritarem slogans a favor do ditador, são indícios do primeiro movimento de massa simpático à idéia de continuidade de Getúlio Vargas. Em maio, grupos organizados interrompem os oradores que comemoram a queda de Berlim e 'quando o escritor Jorge Amado iniciou o comício, dirigindo-se ao povo, grupos foram surgindo, em alguns pontos da Praça [da Sé, em São Paulo], com retratos do Sr. Getúlio Vargas, ostentados em vara-paus. E puseram-se a interromper o orador, com o intuito de impedir que falasse'.,226

Ainda que Vargas não tenha sido deposto por ordem ou constrangimento externo e sim pela cúpula militar de seu governo, com a adesão do Brasil na guerra ao lado dos Aliados, os acontecimentos internacionais também influenciaram as decisões políticas aqui tomadas e exigiram posicionamento político brasileiro sobre os acontecimentos internacionais. Em relação ainda não explícita de antagonismo, tanto a URSS como os Estados Unidos participaram do processo de transição política no curso derradeiro do Estado Novo. Por um lado, os Estados Unidos trataram de incentivar a abertura democrática brasileira e o embaixador norte-americano no Brasil, Adolf Berle, foi mais um dos protagonistas na derrocada final da ditadura de Vargas. Por outro, a orientação de Moscou era que os partidos comunistas em todo o mundo deveriam apoiar os governos de seus países, fossem democracias ou ditaduras, na medida em que eles tivessem participado da luta contra o fascismo. De fato, as políticas externas da URSS e dos Estados Unidos serviram de apoio às correntes que, na política brasileira, disputavam o poder: ou propondo a continuidade de Vargas na Presidência da República até que fosse formulada uma nova Constituição para o país, ou exigindo a abertura democrática imediata e até mesmo a prisão ou o exílio do Ditador.

${ }^{226}$ CARONE, E. Op. cit., pp. 332-333. (parênteses do autor). 
Depois de ser liquidado pelas forças da repressão do Estado Novo, o Partido Comunista do Brasil reorganizourse em 1941. Foi o ano em que as tropas nazistas invadiram a URSS. Voltando ao Brasil um grande número de militantes comunistas residentes no exterior, iniciourse a campanha dos militantes do PCB para a participação do país na guerra ao lado das Nações Aliadas contra o fascismo. Em 1942, “a ação do PCB se amplia, o que o leva a crescer cada vez mais: liderando ou participando, conforme a situação, os comunistas se envolvem com o movimento estudantil, com os núcleos de defesa nacional, com as manifestações públicas a favor das Nações Aliadas, na campanha pela entrada do Brasil na guerra, na luta pela formação da Força Expedicionária Brasileira e na difusão de livros e revistas que defendem a posição de união nacional com Getúlio Vargas etc. A partir de 1942 e 1943, os militantes do partido - pouco importa a posição que adotam em relação ao Estado Novo - estão comprometidos intensamente na luta contra o fascismo externo, contra a agressão nazifascista. Coroando esse esforço de recuperação e de luta, ocorre em agosto de 1943 a II Conferência Nacional do PCB, isto é, a Conferência da Mantiqueira, que dá início à hegemonia do grupo do CNOP - Comissão Nacional de Organização Provisória -, que defende a tese da União Nacional com Getúlio Vargas."227

O documento final da Conferência da Mantiqueira sintetizava a idéia de cooperação de patriotas com Vargas à frente dos esforços de guerra, de colaboração de classes para a derrota definitiva do fascismo. O documento estabelece que "a União Nacional há de ser a conjunção efetiva de esforços de todos os patriotas do Brasil. São patriotas, independentemente dos matizes de suas opiniões políticas, os que aspiram para o bem-estar, progresso e cultura da Pátria. (...) Não são patriotas os pró-nazistas, os quinta-colunistas, os vendidos ao Eixo por dinheiro, ou pela fascinação dos mitos de superioridade racial, do estado corporativo totalitário, da Wermacht 'invencível', massacradora de povos. (...) A União Nacional não há de ser uma mera soma presumida de 'estados de espírito' supostamente congraçados. Há de ser uma conjugação efetiva de esforços, que se traduzirá, por isso mesmo, em realizações objetivas, da mesma forma que a soma dos esforços humanos dentro de uma usina siderúrgica se revela no escoar das corridas de ferro e de aço. (...) Evidentemente, essa união há de realizar-se em torno do governo do Presidente Vargas, que dirige o país em guerra, postas de parte antigas pendências e dissensões, que, neste momento, não se podem alegar nem fazer

${ }^{227}$ CARONE, E. A República liberal - Instituições e classes sociais (1945-1964). V. I. São Paulo: Difel, 1985, pp. 333-334. 
prevalecer diante do quadro supremo da Pátria em luta, na mais difícil e penosa de todas as guerras." 228

Quando saiu da prisão em 1945, Luís Carlos Prestes reafirmou a linha adotada pelo CNOP de União Nacional com Getúlio Vargas. Tratava-se de continuar fiel à linha determinada pela política russa para o mundo. Prestes diz: "Assim como em agosto de 1942 voltourse o nosso povo para o Sr. Getúlio Vargas, na esperança de que o antigo chefe do movimento popular de 1930 quisesse dirigi-lo na luta de morte contra o agressor nazista, o que o nosso povo espera agora do Sr. Getúlio Vargas, prestigiado como está pela vitória de nossas armas na Itália, são eleições livres e honestas. Este, o seu dever de homem e cidadão, e apesar de todas as divergências políticas que já nos separam de S. Excia. contra cujo governo já lutamos de armas na mão, não temos o direito de duvidar do patriotismo do chefe da Nação. (...) O que convém ao nosso povo, aos homens sensatos e honestos de todas as classes, é que as próximas eleições constituam mais um fator, e considerável, de unificação nacional, de paz, de ordem e de tranqüilidade. (...) (Mas, para que houvesse um processo democrático verdadeiro com eleições livres era necessário antes de tudo uma nova constituição para o país:) O que queremos é chegar através da União Nacional à verdadeira democracia, antes e acima de tudo a uma Assembléia Nacional Constituinte de que participem os legítimos representantes do povo, organizado em seus partidos políticos e comitês populares democráticos, para que possa livre e soberanamente discutir e votar a Carta Constitucional que almejamos.

O PCB defendia a convocação de uma Assembléia Nacional Constituinte para o estabelecimento efetivo de uma nova ordem política no Brasil. Carone relata: "No Informe Político apresentado ao Pleno Comitê Nacional (do PCB), Prestes enuncia que 'melhor caminho para a efetiva democratização do país não é certamente o estabelecido pelo Ato Adicional [eleições para Presidente da República e Parlamento]. Reclamamos a convocação de uma Assembléia Constituinte, em que os verdadeiros representantes do povo possam livremente discutir, votar e promulgar a Carta Constitucional que pede a Nação'. Esclarecendo melhor, Prestes em outra ocasião diz que a 'eleição da Assembléia Constituinte surgira para os comunistas como a melhor solução da crise política brasileira que atravessamos. O povo deveria entender que a realização de uma

\footnotetext{
${ }^{228}$ CARONE, E. O P.C.B. (1943-1964). São Paulo: Difel, 1982, pp. 13-14. (parênteses nossos).

229 PRESTES, L. C. "União nacional para a democracia e o progresso" Apud CARONE, E. Op. cit., pp. 37-38. (parênteses nossos).
} 
aparente transformação no regime - com as anunciadas eleições presidenciais e para deputados e conselheiros federais - (...) não era um passo efetivo para a democracia, se os poderes governamentais tivessem de ser exercidos em função de uma Constituição sempre condenada pelo povo. (Era necessária uma constituição democrática para o país, pois) se o presidente da República, se eleito em 2 de dezembro, exercesse o governo com os poderes fascistas da carta de 1937, (ele teria poder) inclusive para dissolver o próprio parlamento.", 230

Com a campanha 'Getúlio com Constituinte', o PCB - que contava na época com grande aceitação popular - objetivava formar uma ampla base no Parlamento e exercer influência decisiva na política do país. Até mesmo depois do naufrágio do movimento queremista e da deposição de Vargas com o golpe de 29 de outubro de 1945, quando Eurico Gaspar Dutra é empossado na presidência da república, o PCB continuou a defender a política de União Nacional. Essa orientação política seria seguida pelos militantes comunistas ligados a Moscou até o momento da ruptura de relações diplomáticas entre o Brasil e a URSS e a cassação do registro do Partido em 1947. Gina Guelman Gomes Machado, apoiada em Michel Löwy, apresenta um depoimento autocrítico que Luís Carlos Prestes faria, anos depois, sobre a estratégia da União Nacional defendida pelo PCB. Diz Prestes: "Em defesa dessa orientação política falsa, chegamos inclusive a cair em posições revisionistas do marxismo-leninismo, como a da tese de 'desenvolvimento pacífico' e da colaboração de classes, ou a tese de luta por uma impossível 'união nacional', bem como a entravar o desenvolvimento da luta de classes nas cidades e no campo."231

A partir da Terceira Reunião Pan-americana, realizada por intermédio do governo dos Estados Unidos na cidade do Rio de Janeiro, entre os dias 15 e 28 de janeiro de 1942, a influência norte-americana se torna determinante no Brasil e nos demais países da América do Sul. Era exigida, por parte dos Estados Unidos, uma tomada de posição clara de repúdio ao nazi-fascismo europeu. Em troca disso, os

\footnotetext{
230 CARONE, E. O Estado Novo (1937-1945). Rio de Janeiro, São Paulo: Difel, 1976, pp. 336-337. (parênteses nossos). Apesar da reivindicação justa por uma nova constituição para o país, o Partido Comunista do Brasil fechava acordo com Getúlio Vargas para que este permanecesse no governo até o fim dos trabalhos da constituinte. A partir daí, e com a conclusão dos trabalhos da Assembléia Nacional Constituinte, seria decidido de que maneira e por que meios se efetivaria ou não o processo de sucessão presidencial. Por sua vez, os oposicionistas se congregavam em torno da candidatura de Eurico Gaspar Dutra ou de Eduardo Gomes.

${ }^{231}$ MACHADO, GINA G. G. Vanguarda Socialista - busca de um caminho independente. Dissertação de mestrado. Faculdade de Filosofia, Letras e Ciências Humanas da Universidade de São Paulo. Orientador: Prof. Dr. Oliveiros S. Ferreira. 1982, p. 25.
} 
Estados Unidos se apresentavam como um mercado estável para transações comerciais e se infiltrava cada vez mais a idéia de que o modelo político a ser seguido pelo Brasil não se encontrava ultramar, na Itália ou na Alemanha, mas no continente americano, mais propriamente na democracia norte-americana. Carone diz: “(A Terceira Reunião) é convocada pelos Estados Unidos "diante da injustificada agressão de que foram vítimas..."; e tem como agenda a proteção do Hemisfério ocidental e a sua solidariedade econômica. As resoluções vitoriosas tratam da ruptura de relações diplomáticas com o Japão, a Alemanha e a Itália, e de questões relativas à produção e ao comércio, a fundação do Banco Interamericano e regulamentação para organização para a luta contra atividades subversivas, isto é, da quinta-coluna nazi-fascista. (...) A recomendação para os países americanos romperem com o Eixo - apesar de não aceita pela Argentina e pelo Peru - leva automaticamente o Brasil a concretizar o ato em 28 de janeiro de 1942."232

Um acontecimento de 1945 demonstra a pressão política exercida pelos Estados Unidos na política brasileira. Foi o episódio Berle. O diplomata norte-americano, que acabara de chegar ao Brasil, faria campanha pela democratização do país e, tempos depois, apoiaria e incentivaria a luta do governo de Eurico Gaspar Dutra contra o comunismo. Carone descreve o ocorrido: "Em 29 de setembro, outra celeuma é levantada por um fato insólito, mas aplaudido pelas oposições. O embaixador americano Adolf Berle faz discurso, em banquete, em que demonstra categoricamente a satisfação dos Estados Unidos pelas eleições no Brasil. Como é o governo brasileiro quem fala constantemente em realização das eleições, aparentemente o discurso parece ser uma forma de aplauso a esta realidade, mas o que o embaixador pretende é forçar o jogo a favor das oposições. No início da oração, Berle mostra que 'jamais foram tão estreitas as relações entre o Brasil e os Estados Unidos quanto hoje o são'. Atualmente o Brasil conquistou a vitória na guerra e 'leva adiante a causa das grandes liberdades humanas; liberdade de opinião, ou estar livre de temor, da privação, e a liberdade religiosa'. (...) 'O mundo inteiro se interessa pelos acontecimentos no Brasil, mas são estes mais de perto acompanhados pelos milhões de amigos norte-americanos do Brasil, que constituem a opinião pública dos Estados Unidos. Aque la opinião pública se regozijou perante a firme determinação brasileira de desenvolver e ativamente empregar as

${ }^{232}$ CARONE, E. Op. cit., pp. 282-283. (parênteses nossos). 
instituições do governo democrático, e aplaudiu os passos dados pelo governo do Brasil para atingir o grande objetivo que é a democracia constitucional'.,233

Getúlio Vargas manobrava para conseguir apoio de grupos políticos e de classes diversas, porém ficava cada vez mais difícil conciliar os interesses da oligarquia situacionista e do exército com os do movimento queremista e do PCB. Quando Vargas foi constrangido a se aproximar mais das massas populares e sinalizou afinidade maior com as propostas do $\mathrm{PCB}$, a oposição à sua permanência no governo cresceu tanto entre os membros do Exército que o apoiavam como entre as oligarquias situacionistas e as tendências políticas ligadas aos Estados Unidos. A disputa chega ao seu clímax: "Vargas manobra e as forças favoráveis a Eduardo Gomes continuam as suas articulações partidárias e a campanha eleitoral. Ataques e contra-ataques são mais radicais a partir de agosto e, em começo de outubro, a idéia do continuísmo getuliano atinge seu ponto alto, e circulam boatos de golpe de ambos os lados. A radicalização (...) leva as partes contrárias a influenciarem forças do Exército denunciando que o presidente da República quer impor governo de massa, ditadura popular, etc. A acusação encontra maior ressonância porque, independentemente, os comunistas têm programa semelhante ao de Getúlio Vargas, o que reforça a tese da convocação da Constituinte e amedronta as oposições."234

O mês de outubro de 1945 marcaria o fim do governo Vargas. A aproximação com as massas, com o PCB e as medidas nacionalistas do ditador brasileiro destroem a sustentação de seu governo. Carone diz: "na medida em que Getúlio se apóia em forças diferentes e joga com elas, sua posição o obriga a satisfazê-las. É assim que as camadas oligárquicas situacionistas, as forças do Exército e os queremistas representam interesses vários, mas estão ligados às atuais estruturas do poder. Como as forças queremistas se deslancham a partir de agosto, crescendo continuadamente nos meses seguintes, a sua expansão ameaça a própria 'frente-única' getulista, canalizada eleitoralmente para a candidatura Eurico G. Dutra. O queremismo, também, por suas

\footnotetext{
233 CARONE, E. Op. cit., p. 340. Continua Carone: “A reação de Getúlio Vargas é de irritação, mas apesar de insólita atitude, o presidente sabe que o discurso vai ser pronunciado e conhece o texto, embora possivelmente não esperasse a sua grande difusão. Como o jogo é de ações recíprocas, o discurso queremista de 3 de outubro, quatro dias depois, é mais do que uma resposta direta às diversas insinuações da oposição. Ainda mais, como o calendário eleitoral se aproxima, a tendência das correntes queremistas e a dos comunistas seria a de transformar o pleito de 2 de dezembro em eleição para uma Assembléia Constituinte, aceitando a inevitabilidade das eleições presidenciais, apenas se isso não fosse possível. Manobrando entre as duas opções, é que Getúlio Vargas pressiona popularmente as massas, manobra com correntes militares e procura se articular com os grupos oligárquicos situacionistas." Idem, ibidem, p. 341. ${ }^{234}$ Idem, ibidem, p. 335-336. (parênteses nossos).
} 
origens populares e populistas, acaba sendo acusado de se identificar com os comunistas, o que leva as oligarquias situacionistas e o Exército a desconfiarem dele, já que os dois últimos possuem caráter conservador e reacionário. A ruptura da 'frenteúnica' getulista faz com que o Exército, que está dividido em alas minoritárias próEduardo Gomes, e majoritária pró-Eurico Gaspar Dutra, se una, liderado ou apoiado pelas oligarquias que até aquele momento apóiam Getúlio. Sem a simpatia das oligarquias e das Forças Armadas, repelido pelos americanos que não vêem com bons olhos as últimas medidas nacionalistas de Getúlio Vargas, este é apeado do poder"235

235 CARONE, E. Op. cit., pp. 337-338. Thomas Skidmore relata o impacto das medidas nacionalistas de Vargas: "Depois de baixar os decretos destinados a 'redemocratizar' o Brasil, Vargas inclinara-se para a esquerda, na sua política interna. Em junho, assinara um decreto 'antitruste', criando uma comissão autorizada a desapropriar qualquer organização cujos negócios estivessem sendo conduzidos de maneira lesiva aos interesses nacionais. $\mathrm{O}$ decreto, que começou a vigorar em $1^{\circ}$ de agosto, tinha por objetivo estabilizar o custo de vida, proibindo a prática do monopólio. Mencionava especificamente 'empresas nacionais ou estrangeiras sabidamente ligadas a associações, 'trustes' ou 'cartéis'”. O decreto provocou o entusiasmo da esquerda e a indignação da direita. A UDN lançou um protesto imediato contra o decreto, considerando-o 'nada mais do que um instrumento do tipo nazi-fascista, com que o ditador ameaça toda a economia brasileira'. A fúria da oposição era particularmente violenta, porque se dizia que o decreto era dirigido principalmente contra a cadeia de jornais de propriedade de um antigetulista declarado, Assis Chateaubriand. Os interesses comerciais dos Estados Unidos também ficaram alarmados com o decreto, por motivos óbvios. Discretamente, estes procuraram obter modificações na sua regulamentação." SKIDMORE, T. Brasil: de Getúlio Vargas a Castelo Branco, 1930-1964. Rio de Janeiro: Paz e Terra, 1982, pp. 75-76. 
Vanguarda Socialista: formação de consciência, democracia e liberdade

Com a anistia política, logo depois de ter sido convidado por Paulo Bittencourt a fazer reportagens como correspondente internacional e de ter seu visto de partida dos Estados Unidos com destino à Europa negado, Mário Pedrosa decidiu voltar ao Brasil e passou a morar na cidade do Rio de Janeiro em 1945. Ali, ele deu continuidade às suas atividades como militante; fundou o semanário Vanguarda Socialista e encarregou-se de escrever muitos editoriais; tornou-se um dos responsáveis pela formação da organização política denominada União Socialista Popular; trabalhou como crítico de arte para o jornal Correio da Manhã, no qual criou uma seção específica dedicada às artes plásticas em novembro de 1946. Pedrosa adquiriu larga experiência política no exterior, como secretário da IV Internacional, desenvolveu estudos e presenciou o que se produzia de mais atual em arte nos Estados Unidos. Foi justamente na passagem por esse país que Pedrosa teve oportunidade não apenas de conhecer Alexander Calder, mas também de consolidar suas idéias sobre política, sociologia e filosofia. ${ }^{236}$

Pedrosa se afastou do movimento trotskista e o semanário Vanguarda Socialista serviu como órgão congregante, investigador e difusor de idéias renovadas sobre cultura, socialismo e democracia, contribuindo efetivamente para o desenvolvimento da tradição intelectual de esquerda no Brasil. Segundo os autores Dainis Karepovs, José Castilho Marques Neto e Michel Löwy, à continuidade inercial do movimento trotskista no Brasil, veio suceder - sob nova direção - a posição de Pedrosa em 1945, que discordava da caracterização dos membros da IV Internacional de que a URSS era um Estado operário degenerado: "O sinal de ruptura vem de fora, Mário Pedrosa, membro do Secretariado Internacional da IV Internacional, de cuja fundação participara em 1938, afastou-se das fileiras trotskistas em 1940: discordava da caracterização que a IV Internacional fazia da URSS - Estado operário degenerado. Pedrosa a caracterizava como um 'Estado livre burocratizado' (entendendo-se Estado livre como sendo um Estado sem compromisso com seus cidadãos, um Estado com um governo despótico). Com o correr do tempo tal posição chega aos demais integrantes da 'primeira geração', que a ela aderem. Não é mera coincidência o fato destes militantes estarem reagrupados, em 1945, em torno das propostas do Jornal Vanguarda Socialista, dirigido por Mário

\footnotetext{
${ }^{236}$ Cf. HOUSTON, M. "Cronologia” In Mário Pedrosa: arte, revolução, reflexão. Centro Cultural Banco
} do Brasil, Porto Alegre, 06-07-1992, pp. 59-60. 
Pedrosa, e não no PSR [Partido Socialista Revolucionário (trotskista) - fundado por Hermínio Sachetta e Rocha Barros].,237

O Vanguarda Socialista pretendia ir além das análises da IV Internacional e também das proposições da Segunda e da Terceira Internacionais. Gina Machado comenta o surgimento do semanário: “Ainda em 1945, com formulações socialistas radicais, mas independentes de qualquer agremiação política, surge o semanário 'Vanguarda Socialista', que reuniu um grupo de intelectuais sob a direção de Mário Pedrosa, com o intuito de formar as bases para a criação de um partido socialista independente no Brasil. O grupo editor do Vanguarda Socialista reunia intelectuais com grande vivência política no movimento socialista e sindical. Discordavam da linha adotada pelo Partido Comunista, pois entendiam que os PCs, subordinados à orientação de Stalin, haviam atrelado o movimento operário internacional aos interesses do Estado russo através de táticas políticas oportunistas. Não se reconheciam entre os socialistas reformistas, pois pretendiam dar continuidade às tradições do socialismo revolucionário. Somavam forças, no entanto, com o movimento da Esquerda Democrática, no que diz respeito ao apoio à candidatura de Eduardo Gomes, pois também consideravam ser esta a única saída democrática para pôr fim ao Estado Novo e ao predomínio de Vargas na política brasileira." 238

A primeira edição do Vanguarda Socialista foi publicada em 31 de agosto de 1945. Nela, Pedrosa e seu grupo redigiram o editorial, intitulado "Diretivas", em que expunham os objetivos seguidos pelo semanário. Seus objetivos: ser uma tribuna de debates sobre temas atuais, fundar um novo partido socialista, funcionar como formador de consciência, pois somente as lideranças e a classe proletária esclarecidas poderiam promover uma transformação social bem-sucedida, e por extensão garantir liberdade de pensamento e de expressão. Isso se refletia na própria constituição plural de seus

\footnotetext{
${ }^{237}$ KAREPOVS, D.; LÖWY, M.; MARQUES NETO, J. C. "Trotsky e o Brasil” In MORAES, J. Q. de. (org.). História do marxismo no Brasil - os influxos teóricos. Volume II. Campinas, SP: Editora da Unicamp, 1995, pp. 243-244. (Colchetes nossos). Para uma descrição completa das caracterizações da natureza do Estado Soviético e de suas tendências históricas ver: Idem, ibidem, pp. 227-228.

${ }^{238}$ MACHADO, GINA G. G. Vanguarda Socialista - busca de um caminho independente. Dissertação de mestrado. Faculdade de Filosofia, Letras e Ciências Humanas da Universidade de São Paulo. Orientador: Prof. Dr. Oliveiros S. Ferreira. 1982, p. 28. Um pequeno grupo formado por Mário Pedrosa, Geraldo Ferraz, Hilcar Leite, Edmundo Muniz e Nelson Veloso era responsável pela produção, divulgação e distribuição do Vanguarda Socialista, mas os estudos e os artigos, nele publicados, contaram também com a colaboração de intelectuais de esquerda, residentes em São Paulo ou no Rio de janeiro, tais como: Arnaldo Pedroso D'Horta, Aristides Lobo, Edgard Carone, Fulvio Abramo, Oliveiros S. Ferreira, Patrícia Galvão; entre outros, uns formados na tradição marxista e outros não. Além disso, eram reproduzidos estudos e artigos de revistas internacionais, tais como: The Call, Masses, La Batalha, The New Leader. Cf. Idem, ibidem, pp. 36-37.
} 
membros, provenientes ou não de organizações políticas e de formação intelectual não idêntica. No editorial está escrito: 'Vanguarda Socialista, como o nome indica, visa fazer a propaganda da idéia socialista a preparar, sem imediatismo ou tempo marcado, quadros para o futuro. Não é ó́gão de nenhum partido, não está sujeita a nenhuma disciplina partidária; é um trabalho coletivo de vários companheiros irmanados por um mesmo ideal e mais ou menos estruturados pela mesma base cultural marxista. Os editores deste semanário, também não pertencem a uma mesma organização política, acontecendo aliás que muitos deles não fazem parte de partido algum." 239

Era preciso salientar que o Vanguarda Socialista não era um veículo de agitação e propaganda, mas de formação de consciência para a fundação de uma nova via socialista: “(Vanguarda Socialista) não é um jornal de agitação para a massa; é um jornal de vanguarda. Isso significa que não visa lançar uma idéia, ou um objetivo exclusivo para uma multidão, e bater e rebater na mesma tecla, até que a massa aja em consequiência dessa agitação; queremos lançar muitas idéias, disseminar um corpo de idéias para os indivíduos, os pequenos grupos a fim de que esses, organizando-se e orientando-se por elas, se reúnam e se preparem para uma ação sistemática e esclarecida sobre o que se chama de largas massas. (...) O grupo de camaradas que se decidem a lançar o presente semanário têm isso em comum: a necessidade de se reorganizar o movimento socialista proletário, nacional e internacionalmente, sobre novas bases, e começando tudo de novo. Porque, na realidade, se trata de começar tudo de novo. Nós vamos aqui, auxiliando-nos mutuamente, e enriquecendo-nos com novos reforços, tentar desenvolver um trabalho de crítica e de construção relativamente ao passado movimento revolucionário ou reformista, comunista ou socialista, tal como evolveu até hoje.",240

Pedrosa e seu grupo se consideravam herdeiros da grande tradição das manifestações revolucionárias do pensamento e da ação. Entre elas, permanecia candente o brilho da Revolução Russa. Porém, mesmo nela era preciso avaliar os erros e acertos, de forma que não se repetissem no tempo presente e na posteridade: "Tentaremos tirar a experiência das formidáveis experiências que vêm abalando a humanidade, desde a primeira grande guerra mundial e a revolução russa, até os carregados dias de hoje, albores pálidos da nova era atômica. (...) Não olharemos para

\footnotetext{
${ }^{239}$ PEDROSA, M. et alii. “Diretivas” In Vanguarda Socialista, Rio de Janeiro, ano I, n’ 1,31 de agosto de 1945, (frontispício). (parênteses nossos).

${ }^{240}$ Idem, ibidem. (parênteses nossos).
} 
nenhum desses acontecimentos com olhos apologéticos. Não aceitaremos nenhuma ideologia, muito menos as oficiais, como explicação desses grandes acontecimentos. Para nós, por exemplo, a revolução russa foi o maior acontecimento do século, e deste, Lenine continua a ser a figura culminante. Mas nem de um nem de outra falaremos com unção religiosa ou beatífica admiração. Queremos tirar partido da importantíssima vantagem de vivermos mais de vinte anos depois daqueles fenômenos acontecerem."241

O Vanguarda Socialista pretendia oferecer uma continuidade de reflexão sobre os grandes acontecimento de nossa época e uma síntese crítica das várias vertentes do pensamento de esquerda e dos movimentos políticos, fossem eles o stalinismo, o trotskismo e/ou a socialdemocracia. Análise objetiva e distanciamento histórico faziam-se necessários não apenas no apontamento dos motivos que permitiram que o stalinismo vicejasse e se estabelecesse na URSS, mas também na avaliação da contribuição tanto do trotskismo para o movimento proletário internacional como do pensamento marxista ocidental. No que concerne aos fenômenos contra-revolucionários como o stalinismo e o fascismo, Pedrosa e seu grupo dizem: “(Não) encararemos o ulterior desenvolvimento da revolução russa ao que se chama hoje de stalinismo, movidos apenas por uma justa indignação de revolucionários que vêem os altos ideais conspurcados pela dura realidade; procuraremos estudá-lo objetivamente, separando o que ali foi ditado pela lei de ferro da necessidade objetiva e o que é conjuntural ou deformação evitável. O fenômeno do fascismo e do nazismo não é para nós, apenas, uma explosão de violência e de sadismo, mas uma resultante orgânica da época contrarevolucionária que mediou entre as duas guerras." 242

Seguem-se homenagem a Trotski e exposição de sua posição sobre a natureza do Estado soviético: "Reputamos igualmente (...) todas as lutas fracionais do passado (...). Nesse sentido encaramos o esforço sobre-humano de Leon Trotski de transportar para o Ocidente a formidável experiência do bolchevismo russo, como praticamente fracassado. A sua tentativa de deslocar a Internacional Comunista do ambiente russo em que pouco a pouco se transformara num instrumento da política externa do Estado russo, no intuito de restaurar- lhe o internacionalismo proletário, para que ficasse apenas, e na realidade, um instrumento a serviço do proletariado mundial independentemente das contingências da política externa soviética, não deu resultado. $\mathrm{O}$ isolamento da revolução russa, em virtude da revolução proletária nos outros grandes países do

\footnotetext{
${ }^{241}$ PEDROSA, M. et alii. Op. cit., (frontispício).

242 Idem, ibidem. (parênteses nossos).
} 
ocidente europeu não se ter dado, consumourse, e o resultado foi o nacionalismo soviético da era atual. Apesar de seu gênio político e da sua flama revolucionária, - a mais pura e a mais alta que já brilhou sobre a face da terra desde Saint Just -, a idéia de Leon Trotski não vingou, mas ele morreu, defendendo, intransigentemente, contra tudo e contra todos, os alicerces econômicos da União Soviética, isto é, a propriedade estatizada dos meios de produção e a planificação econômica, contra qualquer ataque de fora ou de dentro."243

Os militantes do Semanário almejavam a criação de novos partidos socialistas que congregariam tanto os membros egressos do trotskismo quanto os ligados à Segunda Internacional, lideranças da luta encarniçada contra seus inimigos comuns, o capitalismo e o stalinismo: "A Terceira Internacional foi burocraticamente dissolvida quando, como organização política autônoma do proletariado mundial já havia desaparecido. Os atuais partidos comunistas representam de uma parte, o passado e de outra, os interesses do Estado Soviético. Estão condenados à cisão em face das contradições sociais e políticas do mundo atual. Uma parte se transformará, definitivamente, num instrumento totalitário da atual tendência à estatização do capitalismo. A outra parte irá fundir-se às melhores forças proletárias que seguem hoje no campo da segunda Internacional, e constituirão, com outros grupos, os futuros partidos socialistas que serão a síntese do que de melhor trouxe o bolchevismo russo e o que de permanente e fecundo se contém no socialismo ocidental, cuja vitalidade provou ser muito mais irredutível do que pensaram os revolucionários russos."244

O Vanguarda Socialista surgia como expressão de três princípios: a igualdade econômica, a igualdade política e a liberdade de pensamento e de expressão. A diferenciação entre o comunismo e a nova via socialista encontrava-se justamente na compreensão da inseparabilidade daqueles três princípios. Pedrosa e seu grupo foram enfáticos na conclusão do editorial que apresentava o Semanário ao público, quando compararam a importância da liberdade para eles e as tentativas anteriores de edificação socialista: "O nosso semanário refletirá todos esses problemas e anseios. À luz da formidável experiência de nossa época, procuraremos analisar os acontecimentos nacionais e internacionais. Nosso esforço de superação não significa conciliação, que não resolve as contradições, mas apenas as contém resignadas ou passivas; significa realmente um esforço para resolvê-las, fazendo a depuração do que nelas ainda vive, ou

\footnotetext{
${ }^{243}$ PEDROSA, M. et alii. Op. cit., p. 04.

${ }^{244}$ Idem, ibidem, p. 04.
} 
já é morto. (...) Nosso esforço não é ambicioso; pois não é isolado. Por toda parte na Europa como na América, na França ou nos Estados Unidos, na Inglaterra como na Itália ou Alemanha, e até mesmo obscuramente, clandestinamente, talvez em algum recanto da Rússia, ele se vai registrando numa elaboração vagarosa mas constante, porque não passa do processo do próprio pensamento marxista que na volta às suas origens, quer renovar-se ao calor das formidáveis transformações de nossa época. Do fundo de suas pesquisas, estamos certos de uma coisa: é de que a liberdade não soçobrará para que o socialismo triunfe, pois, sem ela, o socialismo jamais será possível." 245

Ainda que houvesse propensão nas "Diretivas" em ressaltar a democracia e a liberdade como princípios insuperáveis na experiência ocidental do marxismo e como principal equívoco da estratégia bolchevista, que terminara com a vitória do stalinismo na URSS, Pedrosa e seu grupo tinham plena consciência de que o problema das relações econômicas transformava-se em impeditivo da igualdade política e do exercício da liberdade no Ocidente. Assim como na URSS a propriedade nacionalizada e a planificação econômica não garantiram, mesmo que transitoriamente, a consolidação da igualdade política e da liberdade, transformando-se em seu contrário, também no Ocidente capitalista a democracia e a liberdade não atingiram seu auge por falta da igualdade econômica. Essa equação entre igualdade econômica, igualdade política e liberdade era de difícil solução e precisava ser atingida para que o socialismo vingasse. Não por outro motivo, os militantes do Vanguarda Socialista visavam à síntese e à atualização das melhores forças da tradição marxista. Elas forneceriam uma resposta concreta aos novos acontecimentos e, por conseguinte, efetivar-se-iam como tentativas de crítica dos dois pólos da equação, a fim de se conseguir da melhor forma possível uma solução para a antinomia histórica, que persistia, entre igualdade econômica e igualdade política mais liberdade.

A opção pela democracia e pela liberdade consistia no diferencial de análise do Vanguarda Socialista. Se a tática bolchevista defendia que a igualdade política e a liberdade, bem como a realização da arte, seriam conquistas posteriores da revolução política com a modificação completa da base econômica e das relações de produção, agora e por causa dos acontecimentos prementes da época, Pedrosa e seu grupo apostavam muito mais na necessidade de se manterem inseparavelmente unidos - na

${ }^{245}$ PEDROSA, M. et alii. Op. cit., p. 04. (parênteses nossos). 
medida do possível - os princípios de igualdade econômica, igualdade política e liberdade, colaborando para a mesma finalidade. Os resultados dessa separação eram evidentes: de um lado, no Ocidente, ocorria uma institucionalização da liberdade em benefício de interesses econômicos socialmente obscurecidos, de outro, na URSS, a supressão completa da democracia e da liberdade em favor da prerrogativa econômica. Não poderia haver antagonismo entre esses princípios, a igualdade econômica não vingaria em detrimento da igualdade política e da liberdade e vice-versa.

O comunismo, o reformismo e as experiências socialistas mais recentes foram objetos principais de análise dos militantes do Vanguarda Socialista. Daí, o lançamento de uma plataforma política denominada "Novos Rumos" - um ano depois da inauguração do semanário -, que visava justamente elaborar alternativas para a transformação socialista. Gina Machado elenca os temas principais do Semanário: “Ao completar um ano de atividade, os editores do semanário elaboraram uma plataforma para discussão entre seus correligionários, colaboradores e leitores, apresentada sob a forma de 18 teses, com o título 'Novos Rumos'. Pretendiam com isso dar mais homogeneidade ao jornal, e conseguir novas adesões (...). As teses de Novos Rumos sintetizavam as principais posições da 'Vanguarda' frente à conjuntura política do pósguerra e refletem os problemas que se colocavam para esses socialistas independentes, tomando-se como parâmetro os avanços do socialismo. (...) Três temas se sobressaem nas teses, e representam o principal esforço de reflexão do jornal frente aos problemas do socialismo: a Revolução Russa e sua evolução através da história, o significado político e econômico da eleição do Partido Trabalhista na Inglaterra, e a questão do imperialismo."246

Como ficou dito acima, o Vanguarda Socialista seguiu de forma consensual a posição de Pedrosa sobre a natureza do Estado soviético. Em polêmica com os trotskistas, que consideravam a propriedade estatizada dos meios de produção e a planificação econômica como conquistas inabaláveis do socialismo frente ao poder político exclusivo da burocracia estatal, o Semanário defendia a posição de que não bastava uma revolução política na URSS, já que a burocracia tornara-se uma nova classe opressora e a economia, capitalista. O regime econômico da URSS seria caracterizado pelos militantes do Vanguarda Socialista como capitalismo de estado.

\footnotetext{
246 MACHADO, GINA G. G. Vanguarda Socialista - busca de um caminho independente. Dissertação de mestrado. Faculdade de Filosofia, Letras e Ciências Humanas da Universidade de São Paulo. Orientador: Prof. Dr. Oliveiros S. Ferreira. 1982, pp. 73-74. (parênteses nossos).
} 
Gina Machado explica: "O proletariado, ao perder o controle político do processo revolucionário, abriu caminho para formação de uma sociedade de classes na Rússia, 'senhora absoluta dos meios de produção e detentora da mais-valia.' A revolução russa, por circunstâncias que remetem às suas próprias peculiaridades, reproduziu, de forma inteiramente nova, o conflito de classes do capitalismo. (A saída era) (a) retomada pelo proletariado da gestão coletiva dos meios de produção e de distribuição do excedente que haviam sido pilhados pela burocracia que se perpetuava no poder, em benefício próprio." 247

O que estava em jogo nas "Diretivas" era mostrar que não havia ocorrido uma transformação efetiva da base econô mica no caso da Revolução Russa - negando a tese de Trotski sobre a nacionalização e o coletivismo da produção como fator de distribuição igualitária do produto social. De fato, havia fraqueza na análise trotskista diante da concentração do poder político e econômico no regime soviético. Esse poder exercido pela burocracia russa se fez então acompanhar da ideologia de que era preciso conquistar, antes de tudo, a igualdade econômica. Essa finalidade última da transformação política, que vetava por tempo indeterminado a realização do processo democrático e permitia o tolhimento da liberdade, era útil para a estabilização política do regime. Por sua vez, a justificação ideológica da garantia progressiva de igualdade econômica servia, no recrudescimento das práticas sociais, como legitimação da ditadura e adiamento histórico da necessidade de igualdade política e da liberdade.

O segundo tema de "Novos Rumos" foi a vitória democrática do Partido Trabalhista na Inglaterra. Essa vitória acenava para uma via alternativa frente ao descrédito sobre o regime soviético. Gina Machado explica: “O Partido Trabalhista teria superado as velhas práticas do reformismo social democrata, ao rejeitar lutar apenas

\footnotetext{
247 MACHADO, GINA G. G. Op. cit., p. 76. (parênteses nossos). Gina Machado continua: "Esta polêmica com os trotskistas em torno da natureza do Estado soviético é farta. Os trotskistas entendiam que a economia estatizada, mesmo sob controle de burocracia, havia superado o conflito capitalista, pela abolição da propriedade privada dos meios de produção. O proletariado seria reconduzido à direção do processo revolucionário, no sentido socialista, através de uma revolução política. A "Vanguarda" rejeitava estes postulados, e insistia na sua tese da necessidade de uma nova renovação social na Rússia, encontrando suas razões no próprio processo revolucionário, do qual se valiam reiteradamente para reforçar as posições do jornal (...). (E o semanário diz:) "Uma vez porém que as forças produtivas da Rússia não tinham chegado ainda a um nível de desenvolvimento capaz de suportar uma organização planificada da economia, ou funcionar sob a forma socializada, objetivo da revolução proletária, o problema fundamental a resolver era o mesmo que havia sido solucionado no ocidente pela burguesia no século passado quando chegou ao poder. Na Rússia, a nova burocracia, que surgiu do Estado soviético, teve que substituir-se à burguesia, e fez na Rússia o papel que aquela não pode realizar. (...) $\mathrm{O}$ proletariado entretanto perdeu nesse processo as suas posições teoricamente privilegiadas no novo processo que se criou. A burocracia estatal tornou-se uma classe, e o proletariado desceu outra vez a ser uma classe oprimida." Idem, ibidem, pp. 76 e 78.
} 
pela preservação de posições já conquistadas pelo proletariado. Enfrentava-se na época uma séria crise no sistema capitalista que se refletia no aumento do 'exército de desempregados' e na ampliação de movimentos direitistas que colocavam em risco os próprios sindicatos operários. A 'idéia do plano' - planejamento econômico - foi então a solução encontrada pelos trabalhistas ingleses para a 'superação do reformismo', na tentativa de conciliação do 'programa mínimo', elaborado para a solução de problemas 'imediatos', e do 'programa máximo', que tinha como meta a 'socialização dos meios de produção' e que era, por sua vez, adiado indefinidamente. Seria justamente em torno do conteúdo deste 'plano', que viria a exigir do governo um ímpeto revolucionário, no sentido transformador, para implantá-1o.,248

O terceiro tema tratado com ênfase no Vanguarda Socialista foi o capitalismo de Estado como nova tendência da economia global e a intensificação da luta imperialista. Gina Machado comenta: “Se, por um lado, a 'Vanguarda' reconhecia na evolução do capitalismo financeiro para novas formas de capitalismo de Estado um avanço no sentido socialista, reconhecia neste processo, novos mecanismos de tensões internacionais, com ameaças à paz mundial, pelo acirramento das disputas imperialistas entre Estados nacionais fortalecidos por esta mesma economia estatal. E isto ocorreria, em razão da tendência de nos próprios países capitalistas, os capitais privados se subordinarem aos interesses 'do estado nacional em concorrência, isto é, em luta com outros estados nacionais para organizar a economia em seu favor'. Desta forma, a luta pela 'redivisão do mundo', que ocorria na competição do capitalismo financeiro pelos mercados mundiais, teria sido substituída por uma luta pela 'dominação do mundo por um dos grandes estados imperialistas, sobretudo Estados Unidos e Rússia.'

\footnotetext{
${ }^{248}$ MACHADO, GINA G. G. Op. cit., p. 81. Gina Machado cita o artigo "Na Inglaterra - reforma ou revolução?", publicado no semanário em 7 de setembro de 1945: "A luta contra os privilégios e a conversão dos monopólios em instituições coletivas pode se processar no domínio do ajustamento jurídico às condições novas de dominação política e numa depuração do aparelho estatal. O proletariado inglês está em vias de exercer na Inglaterra uma hegemonia política que acabará por transformar a estrutura social do país. O partido trabalhista é o partido da classe trabalhadora. (...) Seus chefes, seus burocratas, que vivem no vértice, refletem naturalmente a parte mais conservadora da classe e do partido, dado o seu contato com a oligarquia dirigente do Estado e suas amarras imperialistas. O partido, no entanto, é em si o instrumento mais poderoso e mais direto da ação que o proletariado e as massas populares dispõem hoje para imprimir sua vontade e aspirações ao Estado e à sociedade britânica presentemente. Os elementos revolucionários da Inglaterra deverão estar dentro do partido para reforçar os elementos mais decididos na luta pela execução do programa socialista. (...) Os doutrinários custam a admitir que o processo de socialização se possa desenvolver assim de forma tão prosaica. E a insurreição, e a revolução, a catástrofe, perguntam, ansiados, como se toda teoria sobre a qual se apóiam, se fosse esboroar por isso. Eles esquecem que já Marx, em diversas vezes, falara na possibilidade do proletariado chegar ao poder na Inglaterra sem ser por uma revolução...." Idem, ibidem, pp. 81-82. Em artigos posteriores, o Vanguarda Socialista apontaria as contradições do governo trabalhista britânico: colaboração com o capital financeiro, manutenção do império, luta imperialista. Cf. Idem, ibidem, p. 83.
} 
Paradoxalmente, seria esta tensão, provocada pelas disputas imperialistas, que iria determinar o futuro da humanidade. Através de 'um estado de guerra permanente', a humanidade seria conduzida à barbárie (nova ordem totalitária), ou 'ao tempo da revolução proletária', caso os movimentos socialistas pudessem transcender à guerra imperialista e caminhar no sentido da implantação do socialismo."249

No cenário internacional do pós-guerra se presenciava a tendência de formação de Estados nacionais autônomos e a competição cada vez mais acirrada entre eles. Em uma conferência intitulada "Os socialistas e a III guerra mundial" e apresentada na Associação Brasileira de Imprensa (A.B.I.) em 13 de novembro de 1948, Pedrosa identificava o imperialismo como o grande problema do século. Sua avaliação sobre a situação política no plano internacional fazia coro ao diagnóstico de Lênin: "É que o pai do bolchevismo, quando escreveu sua obra sobre o imperialismo, calcada, toda ela, na obra clássica de Hilferding - "Das Finanzkapital” - assim retratava a situação do mundo já na Primeira Guerra Mundial: 'Monopólio, oligarquia, tendência à dominação e não à liberdade, exploração de um número crescente de nações pequenas ou fracas por uma ínfima minoria de nações ricas ou poderosas.' O retrato da situação no mundo, feito por Lenine, é hoje muito mais exato do que quando ele o descreveu." 250

Não se tratava mais de um cenário em que vários países se encontravam em conflito, mas de dois que disputavam entre si o controle do mundo. Os demais países seguiam a tendência geral de controle das importações e proteção das exportações para que pudessem participar da luta pela conquista de mercados externos. Diz Pedrosa: "Hoje, vemos um mundo apertado demais para caberem dentro dele os imperialistas de Washington e os ditadores de Moscou. Washington pretende organizar o mundo à sua imagem, isto é, à imagem de um liberalismo ultrapassado. (...) O sonho americano é ver os Estados Unidos substituírem a Grã-Bretanha na hegemonia que esta exerceu sobre o mundo em grande parte do século XIX, através da liberdade comercial, instrumento adequado para que se exercesse livremente, nas relações entre os povos, a superioridade da indústria inglesa naquela época. Por isso mesmo, vemos hoje a Grã-Bretanha tornarse um país de economia sitiada, em que os velhos princípios econômicos dos século passado são atirados às urtigas. A Grã Bretanha de hoje é forçada a controlar, a

\footnotetext{
${ }^{249}$ MACHADO, GINA G. G. Op. cit., pp. 79-80. (parênteses nossos).

250 PEDROSA, M. Os socialistas e a III guerra mundial. Rio de Janeiro: Vanguarda Socialista, 13-111948 , p. 01.
} 
selecionar as suas importações, e a proteger por todos os modos as suas exportações de mercadorias, a fim de que possa sobreviver.,251

Para explicar o contexto econômico e político do pós-guerra, Pedrosa retoma a discussão sobre as conseqüências da crise de 1929. A partir dela, entrou em descrédito a tentativa de manter o lastro internacional do ouro como equivalente para o sistema de trocas internacionais e, por conseqüência, permitir o livre intercâmbio comercial de produtos entre os países. Em seu lugar, restava aos países com menos reservas em ouro criar mecanismos próprios de financiamento da produção, tais como: a reserva de mercado ou a fixação do valor da moeda nacional com o intuito de dar mais competitividade aos produtos no mercado externo. Pedrosa diz que a intervenção ou não do Estado na economia tornava-se uma alternativa de vida ou de morte, pois "todo o problema então consistia em escolher entre não intervir, deixando que os milhões de desempregados se acumulassem, que as mercadorias se amontoassem sem escoamento, a fim de que o padrão monetário e o valor do ouro não sofressem ataque, até que de novo, automaticamente, não se sabe quando, os altos fornos da grande indústria voltassem a funcionar (...), ou intervir o Estado para dar trabalho aos desempregados, criar artificialmente mercados, estimulando a procura, elevando muros protecionistas cada vez mais altos, subvencionando as indústrias de exportação para o dumping no exterior, desvalorizando a própria moeda para aumentar a concorrência externa." 252

Os estados totalitários optaram pela segunda alternativa. Agiram contra o capital financeiro e recolocaram as forças produtivas em funcionamento na corrida armamentista para a conquista de novos mercados externos. A disputa econômica transformou-se inevitavelmente em conflito armado. Entretanto, a Segunda Guerra não veio frear esse processo, pelo contrário, ele apenas ganhou posteriormente, como diria Pedrosa, "graus de acabamento diferentes". De fato, houve alternância dos papéis decisivos na política internacional: saíam de cena Alemanha e Japão e entravam Estados Unidos e URSS. Ambos assemelhavam-se no esforço frenético de consolidar áreas de influência. Tanto a URSS quanto os Estados Unidos iniciaram uma disputa por territórios continentais e pela exploração de riquezas no mundo. O elemento chave que unia a luta imperialista antes e depois da guerra foi a preservação do Estado nacional. Seu papel era decisivo no processo de concentração de riquezas e na conservação violenta do ordenamento político-social, externo e interno.

\footnotetext{
${ }^{251}$ Idem, ibidem, p. 02.

${ }^{252}$ PEDROSA, M. Op. cit., p. 06. (parênteses nossos).
} 
Surgiria a partir daí um novo desdobramento no cenário político e econômico internacional. Pedrosa comentava: "No fundo, uma grande revolução econômica se estava operando: a abolição do controle da moeda pelo mercado, com a introdução da 'finança funcional', isto é, a direção das inversões e a regulamentação da taxa de juros de depósitos bancários. O desaparecimento do mecanismo automático do padrão-ouro levou ao isolamento das economias nacionais, e à intervenção crescente do Estado para substituir o automatismo daquele fator regulador. Os grandes problemas da organização industrial se vão, assim, tornando independentes de considerações de ordem puramente financeiras. E este fato colocou em ordem do dia o problema do socialismo, isto é, uma economia organizada para servir o homem, independentemente de considerações não somente financeiras como de fronteiras. Ou isto, ou uma economia limitada ao Estado Nacional, fundida com o Estado e hostil à colaboração internacional, comunicando-se com o mundo exterior como se comunicam por cima dos muros de uma fortaleza, sitiados e sitiantes."253

Pedrosa apostava na oposição da classe trabalhadora frente aos interesses de Estado e aos processos da economia capitalista. Sua organização era fundamental para que houvesse a transformação concreta da sociedade, já que Estado nacional e capitalismo apoiavam-se mutuamente na manutenção dos interesses da classe dominante contra as classes oprimidas e na dominação exercida por Estados fortes contra os concorrentes internacionais. A iniciativa da classe trabalhadora visava ao planejamento da economia e à eliminação das fronteiras nacionais. Pedrosa considerava os trabalhistas ingleses um grande exemplo dessa luta na atualidade. Sua participação "independente e livre" na política, através de cooperativas livres e de sindicatos, consolidaria passo a passo a democracia e evitaria o risco da cooptação pelo Estado. Preservada a autonomia de suas organizações, "haverá sempre esperanças de que a libertação das forças produtivas e econômicas britânicas do automatismo do mercado e das injunções das finanças não sujeitarão o povo a um regime totalitário. De modo que, diferentemente do que se passou na Alemanha, a democracia não é sacrificada ao Moloch do Estado nacional. E, enquanto esta subsistir, o caminho estará livre para uma evolução socialista do capitalismo inglês." 254

\footnotetext{
253 PEDROSA, M. Op. cit., p. 07.

${ }^{254}$ Idem, ibidem, pp. 07-08. Aqui, o autor sugere o confronto com os seguintes artigos publicados no semanário Vanguarda Socialista: "Vanguarda, partidos e socialismo", 19-08-1945, e "Na Inglaterra reforma ou revolução?”, 07-09-1945.
} 
A luta contra o poder do Estado galgava a primeira plana, pois Pedrosa defendia que a realização do socialismo coincidia com a dissolução do Estado. Todas as condições para isso estavam dadas, mas o que se via era justamente um fortalecimento cada vez maior dos setores administrativos e a força de ação dos novos imperialismos no mundo. O caso da URSS é exemplar: as invasões executadas por ela nos países do leste europeu concentravam-se na eliminação da burguesia e dos grandes proprietários de terra para estabelecer em seu lugar o regime político de partido único e a estatização da economia. Essas mudanças eram acompanhadas pela expropriação de grande parte das riquezas dos países invadidos em favor da concentração de recursos na Rússia. Tanto a conquista do poder como o processo de estatização da economia eram levados a cabo por comitês de membros oficiais do partido comunista e de técnicos sem a participação das classes trabalhadoras. Nesse sentido, a ideologia da realização do socialismo ocultava as razões de Estado e a prerrogativa dos interesses econômicos acima dos interesses do homem. Confirma Pedrosa: "A organização da economia socialista se confunde com uma questão de organização técnica, pois tem-se todo o cuidado de suprimir o apoio espontâneo e ativo das massas." 255

Estados Unidos e URSS atuavam como Estados nacionais. Ao contrário, o autêntico socialismo mantinha-se fiel à participação livre e ativa das classes trabalhadoras na organização da economia e à plataforma de abolição das fronteiras e de cooperação internacional. A conclusão de Pedrosa é impressionante: “O Estado nacional soberano é a última forma de dominação política burguesa, quer dizer, de classe. Todo o programa que vise a fortalecer o Estado para que ele organize as forças produtivas em função de seu prestígio e de sua capacidade de competição no exterior é um programa nacionalista e burguês, isto é, anti-socialista. Dentro do Estado nacional, qualquer que seja a estrutura econômica predominante, qualquer que seja seu grau, maior ou menor, de estatização das formas de propriedade, o fundamento político social de tal é a divisão da sociedade em classes. A estatização da economia nessa base nacional não abole, mas agrava a divisão das classes na sociedade. Foi o que aconteceu na Rússia, onde uma casta dominante explora a maioria do povo. Eis porque sua estrutura econômica e social, sua cultura nada têm de socialistas e permanecem inteiramente dentro dos moldes da cultura e da economia burguesas."256

\footnotetext{
${ }^{255}$ PEDROSA, M. Op. cit., p. 14.

${ }^{256}$ Idem, ibidem, p. 14.
} 


\section{$\underline{\text { Vanguarda Socialista: o caso Portinari }}$}

Da atividade do Vanguarda Socialista, que visava ir além das experiências anteriores do socialismo, surgiu a frente de luta contra o capitalismo e contra a influência do Partido Comunista no Brasil tanto em questões de doutrina política como em política cultural. Nas fileiras do Semanário encontrava-se o ímpeto de volta às origens do marxismo para a perscrutação de uma nova via que fosse além dos pontos de retrocesso na implantação do socialismo da URSS e na formulação da doutrina soviética para as artes. Sem dúvida, o Semanário foi - aliado aos esforços de Mário Pedrosa em sua trajetória como crítico de arte - um dos principais veículos brasileiros, ao lado dos intelectuais ligados à revista Clima, de combate sistemático ao realismo socialista, com artigos freqüentes de Patrícia Galvão sobre a situação criativa da literatura no Brasil e no mundo e com artigos de Geraldo Ferraz sobre acontecimentos emblemáticos nas artes plásticas em uma seção exclusiva para esse assunto, além de outros colaboradores. Justamente nessa época, artistas plásticos e escritores brasileiros muito conhecidos tornavam-se recém ingressos no Partido Comunista do Brasil.

No meio artístico brasileiro, a propensão realista nas artes plásticas vinha sendo coroada pela passagem mais ou menos evidente dos temas sobre o cotidiano de pessoas simples e sobre os arredores citadinos para a intensificação da expressão política. Muitos artistas ligados ao antigo grupo Santa Helena que engendraram uma tradição realista, e em certos casos proletária, na pintura moderna brasileira nos anos trinta, levaram a cabo a apuração do tema na pintura nos anos seguintes. Quando Pedrosa chegou ao Brasil e fundou o Vanguarda Socialista, em meados da década seguinte, o problema fundamental de alguns daqueles artistas, e de outros mais, não se limitava à adequação satisfatória entre a pesquisa formal e o conteúdo realista, mas à necessidade de se situarem no novo contexto mundial, cada vez mais polarizado entre as potências vitoriosas ao final da Segunda Guerra Mundial, e na conjuntura nacional, com a volta à atividade dos comunistas. Isso implicava mais do que um movimento em direção ao compromisso social das artes e, por sua vez, alguns artistas brasileiros enfatizaram uma escolha política.

Entre esses artistas, o caso mais interessante de ser assinalado foi o de Cândido Portinari. Seu alinhamento com os stalinistas poderia influenciar gerações, acentuar a 
subordinação da pesquisa formal na pintura ao tema exclusivo da política, ainda que isso não fosse necessário. Menos que um compromisso estético com o realismo socialista, Portinari assumiu um compromisso ético com a causa do Partido Comunista do Brasil. A hora e a vez de crítica ao realismo socialista chegara e Portinari encontrava-se a meio caminho entre a pesquisa plástica cubista e a ênfase realista na arte. Nesse período, todos os intelectuais do Vanguarda Socialista, ao lado de Pedrosa, elaboraram a defesa da liberdade das artes (na linha das conclusões do "Manifesto por uma Arte Revolucionária Independente") contra o estreitamento entre arte e mensagem política. Os militantes do Semanário combatiam a idéia de que a arte deveria ser o reflexo imediato e obrigatório da construção socialista. A diferença que se parecia fundar na vindic ação da liberdade de expressão trazia consigo um elemento a mais, a crítica à consolidação e fixidez de um estilo programático que pretendia atender aos objetivos específicos de propaganda ideológica para o modelo de construção socialista implementado pelos dirigentes do regime soviético.

Além de ganhar notoriedade com a vitória dos Aliados na Segunda Guerra Mundial, o Partido Comunista do Brasil ressurgia, na efervescência da abertura democrática, como uma opção política forte pelo fato de se ter contrapos to no passado à ditadura do Estado Novo. Essa aparente integridade e coerência políticas lhe valeram apreço nos meios intelectual e artístico. Alguns já militavam no PCB, como no caso de Caio Prado Júnior e Jorge Amado, outros aproximaram-se do Partido por causa do apelo que esse fazia à justiça social, entre eles, Cândido Portinari. Todos eles foram militantes ativos e ajudaram na organização das sedes regionais do PCB. No início de 1945, Portinari filia-se ao PCB e decide que sua pintura deveria dar mais ênfase aos temas sociais. Marcos Moreira relata o interesse e a conversão ética do Pintor ao comunismo: "Portinari entrou para o Partido Comunista, por acreditar que o mesmo lutaria pela realização da justiça social. Nunca havia lido um livro de Marx ou Lênin, mas a lembrança de Brodósqui e os comícios do líder comunista Luís Carlos Prestes, que acabara de sair da prisão, convenceram-no a alistar-se. Participou logo, junto com vários artistas, de uma exposição em benefício do seu partido, realizada na Casa do Estudante do Brasil. Candidatou-se, ainda, a deputado federal por São Paulo e recebeu poucos votos, apesar de ser muito popular. Do programa de sua campanha constava uma exposição em São Paulo, que acabou por ser proibida e causou grande confusão.”257

\footnotetext{
${ }^{257}$ MOREIRA, M. Cândido Portinari In "A vida dos grandes brasileiros". São Paulo: Editora Três Ltda., 2003, pp. 95-96.
} 
Sem demora, no segundo número de Vanguarda Socialista, Geraldo Ferraz foi um dos primeiros intelectuais brasileiros a manifestar sua contrariedade com referência ao processo bem-sucedido de cooptação de artistas e de escritores arremetido pelos comunistas brasileiros. ${ }^{258}$ Ferraz faria, mais especificamente, um apelo público a Portinari, a fim de que este reencontrasse, na dinâmica de seu próprio trabalho livre, a verdadeira justificação e motivação criativa. Do contrário, os comunistas ganhavam e os artistas perdiam. Não era para menos, a adesão de um artista tão notório como Portinari ao PCB revertia-se em evidente propaganda e benefício político para Luiz Carlos Prestes, sem que isso fosse acompanhado de um ganho ou transformação positiva do estatuto comunista para as artes. Os comunistas ligados ao PCB, como se sabe, seguiam à risca as determinações soviéticas com respeito à arte e não estavam interessados de verdade na contribuição criativa e plástica que os artistas modernos poderiam trazer.

Eis aí toda a cilada da filiação. Certamente, havia o precedente do realismo como elemento intrínseco nas obras de artistas brasileiros do feitio de Portinari, mas a extensão disso para um compromisso com a doutrina política do comunismo no campo estético foi a grande virada na aproximação entre comunistas e artistas plásticos e escritores. Tal e qual salientou Geraldo Ferraz, em sua crítica a Pedro Pomar - um ideólogo brasileiro do Realismo Socialista ${ }^{259}$-, escondia-se por trás do véu da aparente afinidade de interesses entre comunistas e artistas modernos, uma compreensão diversa sobre o produto artístico. Enquanto Pomar guiava-se por uma reprodução fidedigna da realidade executada pela arte, os artistas modernos, como Portinari, centravam a reprodução da realidade na pesquisa da forma. Isso se dava no decurso de uma indagação sobre o modelo tradicional de representação tanto da figura humana como do espaço subjacente ou circundante. O recurso básico de Portinari na pesquisa da forma era o expediente da deformação, a síntese de visões parciais do objeto para a investigação e conhecimento de novas concepções de tempo e de espaço.

Segundo Pedro Pomar, a negação da deformação picassiana e a aceitação de uma pretensa estruturação da realidade fornecida pelo modelo da perspectiva renascentista constituíam a base para a criação artística. Mais do que isso, a posição de Pomar concernia à concepção da arte como reflexo da realidade; a obra seria capaz de

\footnotetext{
${ }^{258}$ FERRAZ, G. "O P.C.B. e a liberdade de criação" In Vanguarda Socialista, Rio de Janeiro, ano I, n ${ }^{\circ} 2$, 07 de setembro de 1945. Cf. também o artigo de Pedrosa "O Senador Portinari", publicado no Correio da Manhã em 30-01-1947.

${ }^{259}$ Cf. POMAR, Pedro. "O Partido Comunis ta e a liberdade de criação" In Tribuna da Imprensa, Rio de Janeiro, RJ, 11 (?) e 18-08-1945.
} 
emocionar o espectador com sua forma clara e coesa e com seu conteúdo específico da criação socialista. Diz Pomar: "Imaginam muitos artistas que estamos de acordo com os aleijões propositados, com as deformações intencionais, com os exageros dos esnobistas. Não, amigos (...) gostamos da arte humana, que reflita os sentimentos do proletariado e do povo em busca da perfeição humana."260 Essa fixação da imagem humana e de uma visão positiva da construção do socialismo interditava toda elaboração da forma conforme as regras de descontinuidade, contradição, opacidade. Essas eram as características atribuídas à arte moderna e refletiam a decadência da sociedade burguesa.

O apoio político de Portinari ao Partido Comunista, na visão de Geraldo Ferraz, estava em flagrante contradição com sua própria arte. É certo que - como vimos - havia um interesse sincero do Pintor brasileiro pela técnica acadêmica de composição da imagem, mas também uma assimilação, nas suas obras, da visão analítica e sintética do cubismo, além da deformação picassiana, condenada por Pedro Pomar. Acreditava-se em uma declinação das posições políticas de Portinari ou na estratégia de se evitar o pior: que ele abandonasse a pesquisa artística em favor de um pretenso realismo mais assemelhado com um naturalismo conservador do século XIX. As palavras de Ferraz chamam a um posicionamento lúcido do Pintor brasileiro: "Portinari (...) quando você pinta uma deformação, você está fazendo arte humana, boa arte, da melhor, dessa que não pode ser alcançada pela excomunhão dos dogmas totalitários. Desengane-se, Portinari. Você está apenas procurando o social - ele, acidentalmente aconteceu, e você está de acordo que assim seja. Mas não se submeta, não nos queira dizer que está errando, ou copiando deformações, naturalisticamente, pense na sua Arte, Portinari. Defenda-se.",261

Contestava-se o interesse veemente dos artistas no meio artístico brasileiro de estreitarem vínculo com o Partido Comunista, uma vez que já estava provado o conflito estabelecido entre as posições políticas defendidas pelos comunistas no campo estético e a arte moderna. Nessa circunstância singular das artes brasileiras, a crítica de Geraldo Ferraz volta à baila com a organização de uma exposição de confraternização entre artistas tanto modernos quanto acadêmicos e Luis Carlos Prestes, na Casa do Estudante do Brasil em 20 de outubro de 1945. Como era possível enxergar nessa enormidade mais do que um interesse de promoção interna do PCB? Ou então, que interesse

\footnotetext{
${ }^{260}$ FERRAZ, G. Op. cit., p. 02.

${ }^{261}$ Idem, ibidem, p. 02.
} 
exclusivamente artístico pensavam, alguns daqueles artistas, contemplar com sua adesão aberta ao PCB? Ferraz descreve a situação: "É realmente difícil descobrir as origens desta exposição que no catálogo se chama 'Artistas plásticos ao Partido Comunista do Brasil', se se excluir delas a coceira dos mesmos artistas plásticos no anseio de manifestar sua identidade com a 'ideologia avançada' desse agrupamento político. É claro que uns pensaram assim, outros se afobaram para dar sua adesão e de uns e de outros saiu o golpe para apanhar os que se achavam mais distantes (...). Por outro lado, a seção intelectual e artística se agitou (...) para demonstrar (...) a importância de um Partido, que tem dentro de si os melhores artistas contemporâneos do Brasil."262

Ferraz perguntava pelo sentido unificador que faltava àquela exposição. De fato, não havia uma unidade evidente entre aquele ajuntamento de artistas além do posicionamento público de uma parte deles. Ali, espraiava-se uma confraternização avessa à arte mesma ou ao valor independente da arte, pois se uniam em um único espaço expositivo as expressões mais díspares - acadêmicos e modernos - em torno da proposta de homenagem ao comunismo e, também, ao ingresso de Cândido Portinari no Partido. O resultado disso foi o rebaixamento do significado da arte moderna com seu mérito de independência e renovação, além da perda da oportunidade de tomar a exposição como linha divisória entre a arte dirigida e a arte moderna. Comenta Ferraz: "entretanto, a excelente oportunidade se perdeu e sob o signo do Partido ocorreu por parte dos modernos, pela primeira vez na história destas precárias artes plásticas brasileiras, que tais artistas se dirigissem aos outros em termos de confraternização conciliatória e simpática, na solução artística unitária, a qual reconhece os mesmos direitos à pintura que até na cabeça do Sr. Capanema não deve ser posta no mesmo Salão."263

Ferraz apoiava-se na invencível diferença motivadora do surgimento da arte moderna; sua existência e sua verdadeira razão de ser nasceram da crítica aguda aos pressupostos da arte acadêmica, sendo assim não se poderia justificar tal exposição, onde se encontravam lado a lado artistas acadêmicos e modernos, sob pena de se tomar,

\footnotetext{
262 FERRAZ, G. “Os artistas e o Partido Comunista” In Vanguarda Socialista, Rio de Janeiro, ano I, n 10, 02 de novembro de 1945, p. 02. Republicado em BRETON, A. \& TROTSKI, L. Por uma arte revolucionária independente. São Paulo: Paz e Terra - CEMAP, 1984, pp. 168-170. A exposição denominada "Artistas plásticos ao Partido Comunista do Brasil" foi resultado do acordo entre vários artistas militantes e simpatizantes do PCB, unidos independentemente de filiação artística, com o intuito de angariar fundos para que o PCB participasse das eleições. Também nessa época, Luis Carlos Prestes deu várias palestras com entrada paga. Muitos quadros foram vendidos e Cândido Portinari ofereceu para a exposição um quadro, que ele havia pintado naquele ano, intitulado "A Roda".

${ }^{263}$ Idem, ibidem, p. 03.
} 
a questão política como mais importante do que a arte ali apresentada. Não se podia admitir que os artistas modernos na exposição trabalhassem contra si próprios e pela destituição do lugar ocupado pela arte moderna após batalha contra aquela arte antiga e burguesa, em favor de uma expressão renovadora e revolucionária do mundo. Esse era o perigo iminente que corriam os artistas modernos daquela exposição, em conseqüênc ia do estreitamento equívoco entre revolução política e revolução artística. ${ }^{264}$ Esse estreitamento considerava necessário que a transformação social trouxesse consigo e pronta a essência de uma nova arte, ou que esta fizesse parte da mera construção política de uma nova sociedade.

Ainda que existissem artistas de todos os matizes na exposição e também aqueles distantes da temática política com obras como "Cabra' de Pancetti, a 'Paisagem' de Bonadei, 'Natureza Morta' de Roberto Burle Marx”, tentava-se criar uma unidade justificadora da exposição. Ferraz apontava, na falsa unidade estabelecida, o motivo restrito da iniciativa política: "A solução unitária é pois a primeira nota falsa a soar na decantada realização artística, (...), que a manha dos espertos timbra em cobrir com a desculpa que faz arte, quando o que realiza é adesão ao Partido, pretendendo jogar poeira nos olhos dos artistas, do público e dos crentes". Caberia ao tempo demonstrar quem eram os verdadeiros amigos da arte moderna e quem procurava beneficiar-se da instrumentalização das artes. Nesse sentido, Ferraz concluiria seu artigo: "A sola grossa que faz sua entrada nesta sala, ringindo sedenta de benefícios à sofismada vanguarda do proletariado é aqui admitida pelas confusões da transição presente." ${ }^{265}$. Na verdade, não existia unidade entre os artistas ali expostos e a confraternização entre eles não se fazia no terreno próprio da arte. $\mathrm{Na}$ verdade, o que justificou em grande parte a exposição foi o encontro público entre Cândido Portinari, um dos maiores e mais conhecidos artistas brasileiros na época, e o líder do Partido Comunista Luis Carlos Prestes.

Não era para menos. Portinari ganhara fama internacional na Feira de Arte de Nova York, 1939, com os murais de Washington, em 1942, e receberia convite para expor na França, em 1946, o que reforçou ainda mais sua notoriedade no Brasil. Quando o Pintor decide empenhar-se na denúncia dos problemas sociais e acrescenta a isso a

\footnotetext{
264 Anos mais tarde, Pedrosa chegaria a julgar que o processo de consciência, inaugurado pela égide da sensibilidade, cujo motor por excelência eram as artes, far-se-ia em concomitância com os processos de transformação política e social. A síntese desses processos era indispensável, mas a transformação profunda e durável viria com a contribuição definitiva da arte. Cf. PEDROSA, M. "Arte e revolução" (1957) In Política das Artes, (organização Otília B. F. Arantes). São Paulo: EDUSP, 1995, p. 98.

${ }^{265}$ FERRAZ, G. Op. cit., p. 03.
} 
adesão ao Partido Comunista, inicia-se também a predileção e a tomada de consciência de seus processos criativos com o intuito de defini-los em conformidade com sua opção política. A entrada do Pintor no Partido servia até mesmo para indicar e acentuar um interesse compartilhado pelo realismo na pintura e pela tendência social na arte. De fato, esses dois elementos mesclavam-se nas obras de Portinari, mas o resultado de um processo livre de descoberta artística não deveria estreitar afinidades com as manifestações artísticas programadas e dirigidas pelos comunistas. Esse foi seu erro, na medida em que manter ligação com o Partido Comunista significava, acima de tudo, aprovar a importância dos preceitos ideológicos do stalinismo na construção do universo artístico. ${ }^{266}$

Ferraz endossaria isso em seu artigo sobre uma conferência de Portinari a artistas e intelectuais na Associação Brasileira da Imprensa. Ali, o Pintor tratou de ressaltar o valor do processo criativo pela sua proximidade com os temas sociais. Toda pintura que não levasse isso em conta estaria condenada a ser uma expressão menor, sem validade histórica. Para Ferraz, os comentários do Pintor brasileiro sobre a função artística faziam transparecer seu interesse pela cada vez mais acentuado pela política: “Andam os jornais cheios de glorificação a Cândido Portinari (...) não sei se por causa dessa (...) ou da candidatura a deputado pelo partido Comunista, o que esperamos que nunca aconteça a Picasso (...) não sei, dizia, porque anda o Sr. Cândido Portinari tão palavroso, a ponto de promover sabatinas de artistas como há duas sema nas o fez, na A.B.I., liderando os artistas plásticos à imitação do 'filho querido do povo'. Fê-lo para marcar uma orientação artística, para que seus colegas fiquem sabendo que "pintura que

266 É dessa época o depoimento de Portinari sobre o significado de sua atividade artística para a política. O Pintor tinha se tornado muito mais que um admirador de Prestes e simpatizante dos comunistas, tornara-se membro do Partido Comunista do Brasil e sua fala reflete muitas das inquietações e das determinações da União Nacional propugnada pelo Partido. Portinari diz: 'Confesso que foi grande a minha emoção ao saber da inclusão do meu nome na chapa do Partido Comunista. Se não se tratasse desse partido, de maneira nenhuma aceitaria. Você compreende, não tenho jeito para deputado, mas pertenço ao povo, com todos os seus defeitos e qualidades, por isso lutarei pelo partido do povo (...) Resolvi aceitar a inclusão do meu nome porque considero o Partido Comunista como a única grande muralha contra o fascismo e a reação, que tentam sobrenadar ao dilúvio a que foram arrastados pelos acontecimentos. É preciso haver uma mudança, o homem merece uma existência mais digna. Minha arma é a pintura". s. a. "Portinari, candidato dos comunistas" In Diretrizes, Rio de Janeiro, dezembro de 1945 Apud Projeto Portinari, Cronobiografia. Disponível em: http://www.portinari.org.br/ppsite/ppacervo/cronobio.pdf, p. 24. Acesso em: 16-032006. 
se desliga do povo não é arte', pois ele 'não conhece nenhuma grande arte, que não seja intimamente ligada ao povo', e outra qualquer pintura não é mais senão 'passatempo, um jogo de cores cuja mensagem vai de epiderme em epiderme'.,267

A proximidade do artista com "o povo", reivindicada por Portinari, seria conseguida pelo caráter compreensível e didático na arte, em sua referência às formas naturalistas. Com isso, os elementos modernos da pintura eram relegados a segundo plano, transformados em motivos de simples acabamento, e o procedimento central de elaboração da imagem terminava por se pautar em recursos disponíveis no naturalismo pictórico. O que Ferraz mostrava era que os objetivos da arte estavam em conflito frontal com os objetivos políticos do Partido Comunista, de modo que a potencialidade revolucionária inscrita na arte moderna estava ameaçada. Ao contrário, o naturalismo ou estrutura clássica - concebida como fator originário da composição pictórica - visava satisfazer apenas a repressão das capacidades cognitivas e, por conseguinte, libertadoras da arte na sua função maior de educar o homem contemporâneo através da renovação da sensibilidade e do entendimento estético. Por isso, a arte moderna atuava onde a política stalinista não tinha outro efeito a não ser a restrição da criatividade.

Ferraz concluía que a concessão naturalista convertia-se na maior preocupação de Portinari para explicar os fundamentos da criação artística, quando, por ocasião de sua conferência na A.B.I., ele dividiu os artistas contemporâneos em dois grupos (Ferraz cita Portinari): “'Há também em pintura muita maneira de expressão. Uns pela naturalista, outros até mesmo por uma espécie de código, como acontece com o grande pintor espanhol Miró",268 Todos os artistas sem exceção seriam levados sempre a moldar suas criações em uma referência pelo menos miúda à natureza, ao mundo concreto. Decorre disso que o fundamento naturalista ganhava terreno e esse erro foi apontado por Ferraz na análise das idéias de Portinari, como uma "extravagância militante da arte que o Partido Comunista quer que seja indiscriminada", ${ }^{269}$ pois não era possível encontrar um fundamento simplificado e muito menos naturalista ou neoclássico para a arte moderna e tergiversar atitudes muito distintas de expressão e de compreensão do fenômeno artístico.

\footnotetext{
${ }^{267}$ FERRAZ, G. "Assim falou Portinari” In Vanguarda Socialista, Rio de Janeiro, ano I, n 33, 12 de abril de 1946, p. 05. Republicado em BRETON, A. \& TROTSKI, L. Por uma arte revolucionária independente. São Paulo: Paz e Terra - CEMAP, 1984, pp. 172-174.

268 Idem, ibidem, p. 05.

${ }^{269}$ Idem, ibidem, p. 05.
} 
Além do sucesso nos Estados Unidos, a aclamação de Portinari na Europa veio com o convite de Germain Bazin para que ele expusesse seus quadros na Galerie Charpentier em Paris. Essa exposição, realizada em 2 de outubro de 1946, foi significativa, pois nela se observa tanto a acolhida calorosa das obras do pintor brasileiro pelos militantes do Partido Comunista Francês como o início da fase de Portinari com pinturas de temática social acentuada. Por um lado, o militante do PCF Louis Aragon enfatizou o caráter eminentemente nacional das obras de Portinari, em um contexto histórico-social francês que remetia à União Nacional como política acertada contra a ocupação e a vitória final contra a ameaça nazi-fascista. Além disso, Aragon falava da posição que ocupava Paris como centro da cultura mundial antes da guerra para demonstrar que o ideal da cultura internacional, depois dos acontecimentos da Segunda Guerra, se encontrava também na mensagem artística do Pintor Brasileiro. Por outro lado, Portinari levou para a exposição, em Paris, obras como: "Menino morto", "Enterro", "Retirantes". Em todas elas, ressaltavam-se os camponeses e os trabalhadores, com os corpos esquálidos ou com as marcas do sofrimento, acentuados pelo traço expressionista e pela predominância de cores carregadas em tons sombrios. $\mathrm{Na}$ apresentação das contradições evidentes da realidade, Portinari denunciava a realidade selvagem e absurda do Brasil. A mensagem de Aragon e de Portinari eram em favor dos PCs como solução política definitiva para as mazelas sociais por que passavam os povos do mundo. ${ }^{270}$

$\mathrm{Na}$ inauguração da exposição de Portinari em Paris, Aragon declarou: "A França, e principalmente Paris, tem o hábito de se considerar como o centro de toda arte, mas a França e Paris, hoje, não são exatamente a França e Paris de uma época em que a França e Paris não tinham ainda sofrido. Hoje em dia, quando em Paris, quando na França, recebemos um artista estrangeiro e sentimos nele a expressão profunda, exata, humana, arrebatadora de sua nação, quando descobrimos nele um verdadeiro

\footnotetext{
${ }^{270}$ Depois de sua derrota na eleição em que se candidatara como deputado federal por São Paulo, Portinari foi a Paris para inaugurar sua exposição. Marcos Moreira comenta: “[Em] 1946, [Portinari] viajou com Maria e João Cândido para fazer sua primeira exposição na Europa [...]. Levou os quadros a óleo da série 'Os Retirantes' (...) e os desenhos da série Meninos de Brodósqui. Todos os 'meninos' têm o rosto triste e são pobres, [...]. O conjunto dos quadros e dos desenhos é extremamente dramático. [...] A exposição foi um sucesso notável. Os maiores críticos franceses elogiaram o artista brasileiro. Germain Bazin, o conservador do Museu do Louvre, chamou-o de 'Michelangelo brasileiro', René Huyghe, o diretor do museu, afirmou: "na manhã em que vi o conjunto de suas telas senti uma tal emoção que sai da Galeria Charpentier nervosamente excitado. Naquela tarde não me foi possível trabalhar. [...] Mais tarde, o próprio Huyghe diria: 'Ele (Portinari) nos revela a alma sul-americana e representa a nossa época nos aspectos de drama, de tristeza e miséria'." MOREIRA, M. Cândido Portinari In "A vida dos grandes brasileiros". São Paulo: Editora Três Ltda., 2003, p. 96. (colchetes nossos).
} 
artista nacional, nós o acolhemos de maneira diferente do que faríamos em 1939, porque durante esses últimos anos aprendemos, às nossas custas, por experiência própria, o preço da Alma Nacional. É por isso que Portinari, que chegou hoje a Paris, foi recebido com mais emoção do que ele, na certa, esperava. Os que vêem aqui essas telas tão essencialmente brasileiras, em que a vida do Brasil, em que o espírito de um povo que amamos sem conhecer verdadeiramente nos detalhes da vida cotidiana, se refletem de um modo tão intenso, então nós, franceses, sabemos que nos encontramos diante de homens que, como nós, podem amanhã estar sujeitos à morte, podem amanhã estar sujeitos à opressão e que, como nós, têm a dar ao mundo uma mensagem preciosa. Assim, aqui não consideramos Portinari como um estrangeiro; Portinari é, isso sim, um grande artista que fala a mesma língua que nós, esta língua que faz a grandeza dos franceses, dos brasileiros, dos homens; essa grande língua que não estanca diante de nada, de nenhuma consideração de escola e, no entanto, é rica de todos os ensinamentos dos mestres modernos, de toda a grande tradição da pintura. É valioso para nós que ele venha deste modo se exprimir em Paris, onde ajudará certamente até mesmo aqueles da Escola de Paris que frequentemente se julgam os donos do mundo, a vencerem suas pequenas apreensões, seus pequenos complexos e seu pudor" ${ }^{271}$.

Para Aragon, a arte de Portinari constituía um exemplo a ser seguido pelos membros da Escola de Paris, representada aí por todos os artistas de vanguarda radicados naquela cidade: Léger, Picasso, etc. Nisto consistia sua vantagem frente à Escola de Paris - que o tinha influenciado desde o princípio -, Portinari não tinha cerimônia, "pequenos complexos" nem mesmo "pudor" em apresentar a realidade tal como ela era ${ }^{272}$. O Pintor aderira sem titubear à via da arte de tendência social, era esse seu novo mote, sua tentativa de realização como artista e também como militante do Partido Comunista. Marcos Moreira descreve a trajetória de Portinari: "No fim de 1946, o pintor, sua mulher e seu filho voltaram ao Brasil e foram passar o Natal em Brodósqui. (...) A carreira política de Portinari iria continuar em 1947, ele se candidatou

\footnotetext{
271 ARAGON, Louis. “Allocution faite par Louis Aragon a l'occasion du vernissage de l'exposition Portinari à la Galerie Chapentier". (texto datilografado). Projeto Portinari. Disponível em: http://www.portinari.org.br/ppsite/ppacervo/vejamais.asp?notacao=TX;5;1\&ind=1\&No meRS=rsPSComDoc_APTX\&Modo=C\# . Acesso em: 15/03/2006.

${ }^{272}$ Louis Aragon certamente não se referia a Pablo Picasso, que exerceu influência decisiva na trajetória de Portinari. Talvez, Aragon endereçasse sua crítica a Fernand Léger. O certo é que se iniciava na França a batalha entre arte moderna e realismo figurativo e, para Aragon, Portinari apontava a via realista e figurativa para continuidade da arte contemporânea.
} 
a senador por São Paulo. Na campanha percorreu o interior do Estado em que nascera, discursou de cima de caminhões, entrou novamente em contato com o povo mais simples. Fazia o que era necessário para ganhar mais votos, sabia que em São Paulo só um homem famoso como ele poderia vencer uma eleição pelo Partido Comunista. Todas essas atividades, porém, diminuíram-lhe o tempo para pintar e desenhar, o que muito o preocupava."273

A série de obras intitulada "Retirantes" pode ser considerada um dos temas mais dramáticos no conjunto da obra de Portinari. É como se o próprio pintor já tivesse passado por aquilo. Sua origem camponesa permitia uma identificação profunda com o sofrimento das famílias de retirantes, que ele representava em seus quadros. Neles, o tom de denúncia é muito forte. Portinari não descarna os personagens dessa constante fuga da fome, cheios de humilhação, mas apresenta-os em pele e osso. Figuras esquálidas em que se pressentem apenas pequenos resíduos de humanidade. Desfiguradas e mutiladas pela realidade bruta e selvagem em que vivem, elas se tornam paradoxalmente muito mais humanas. Veja-se, por exemplo, o quadro de 1944. De tons sombrios, nele predomina o preto em contraste com algumas pinceladas de branco nas vestes e nos corpos, que dão a impressão nas vestes de encardido e nos corpos de palidez mórbida, falta de sangue e de vida. No horizonte predomina a mistura do azul com o preto, carregando o céu acima das cabeças dos retirantes e diminuindo a dimensão e a amplitude do espaço. O cenário torna-se sufocante, mesmo que o horizonte aponte para a luz. Abaixo dos pés descalços e feridos, a terra em tons marrons parecidos ao das primeiras pinturas de Portinari sobre Brodósqui.

Os rostos dos homens, da mulher e das crianças pendem em diagonais cruzadas, como se os olhares deles, que se fecham em um conjunto na forma de leque ou de semicírculo e cobrem toda a área do quadro, fitassem o espectador em qualquer canto que esse se detivesse para observar. Não são olhares amedrontadores, mas de pessoas sofridas. Não pedem compaixão, mas fazem com que o espectador pergunte a si próprio o que ele mesmo ainda tem de humanidade, já que ele e os retirantes fazem parte de uma mesma sociedade. Portinari enfatiza no desenho das figuras os membros retorcidos de dor e de dano, a deformação das faces que apenas deixam entrever uma pequena semelhança com imagens de homens, mulher e crianças. Também, os pés e as mãos exagerados de telas anteriores dão lugar a pés e mãos que se assemelham com paus

${ }^{273}$ MOREIRA, M. Op. cit., p. 97. 
secos, com raízes de árvores retorcidas e mortas. As diagonais, em que se observam pares de rostos, enfatizam as dessemelhanças entre os rostos, mas a expressão de angústia das figuras e o desejo interior de vida, ou o que resta dele, são os mesmos para o conjunto.

O que se percebe nas figuras como uma centelha de vida é transfigurado por cortes nas faces ou nos corpos. Tanto o rosto do ancião, à esquerda da tela, como o do pai de família, no centro para o lado direito, são quadriculados por traços que se assemelham aos cortes de uma navalha, sugerindo vincos da pele castigada pelo sol e pela poeira. As crianças têm olhares que variam com suas idades e que vão da inocência frente à catástrofe que lhes arranca a vida até a atitude de compreensão confusa da situação. De modo geral, é possível observar a influência de "Guernica" de Picasso. A semelhança transparece não apenas na tentativa de retratar a dramaticidade social vivida, mas também no tratamento das figuras. A mulher no centro do quadro, que acompanha os homens e avança na direção do espectador, carregando um balaio de roupas na cabeça e uma criança no colo, parece-se muito com "Mulher chorando", 1937, do pintor espanhol. Sua cabeça, posta em viés, e seu semblante cheio de angústia e desolação retratam, assim como em Picasso, os sentimentos e o estado de ânimo mais que o aspecto exterior.

Em "Retirantes" de 1944, Portinari utiliza a deformação da aparência externa da figura humana para ressaltar, entre o interior não visível do corpo e a epiderme, emoções profundas. Isso é feito com geometria. Seu quadro está a meio caminho dos procedimentos realistas e dos cubistas. Em "Mulher chorando" de Picasso, 1937, a geometria transmutava-se em sentimentos. Aplicada ao rosto, olhos, nariz e boca, ela servia para evidenciar a tristeza pelo luto. Em Portinari, a geometria serve como deformação do corpo, introdução de reentrâncias e protuberâncias, mas sempre balizada pelo apego à forma realista. Se, em Picasso, observa-se a transmutação da geometria em sentimento, em Portinari, a geometria serve como apêndice realista, pois suas figuras seguem um padrão de estrutura convencional, acadêmico. A conciliação entre cubismo e estrutura convencional destacava o tema. Este, por sua vez, inaugurou a fase de compromisso de Portinari com o social em forma de denúncia e de combate. Sem par na obra do Pintor, os "Retirantes" estavam longe das soluções plásticas encontradas nas séries sobre Brodósqui, nas pinturas históricas e nas pinturas que tinham como tema específico o trabalho. 
Portinari chegara com os "Retirantes" ao ponto mais alto de aproximação dos recursos expressivos da arte moderna com a temática social combativa. Não se tratava de uma inovação capaz de pelo choque despertar consciências, pois a via realista fazia parte do establishment e se transformara em prática corrente e anestésica, mas do coroamento da via realista, do combate social, na arte moderna. Às artes plásticas brasileiras, em especial à pintura, atrelavam-se cada vez mais um sentido e uma expressão estética comprometidos com o discurso vazio de mutação política e social, com as trapaças e batalhas ideológicas, restando pouco da significação vivaz e espontânea que acompanhou as vanguardas artísticas no início do século XX. Era um outro momento para as artes, no qual estava em jogo sua própria definição desimpedida e condizente com o conjunto das forças renovadoras em todos os campos de atividade humana. $\mathrm{Ou}$ isso, ou a normalização das práticas artísticas modernas que convinha muito pouco aos interesses cognitivos da arte enquanto favorecia uma abertura à retórica social alinhada. 
$\underline{\text { Solução ou impasse? - A contribuição de Portinari para a arte moderna brasileira }}$

O fim do Estado Novo trouxe mudanças decisivas na política brasileira. Depois da vitória em pleito eleitoral, Eurico Gaspar Dutra tornoutse presidente do Brasil em 31 de janeiro de 1946. Seu governo efetivou medidas contra o operariado, promoveu o fechamento do Partido Comunista do Brasil e a aproximação política com os Estados Unidos. Edgard Carone descreve: "a tendência econômica do governo é abertamente favorável ao laissez-faire, principalmente quando atende à demanda das classes poderosas e as enriquecidas durante o Estado novo, além do capitalismo estrangeiro (...). Em compensação, (o governo) mostra-se contrário às conquistas das estatais, tendo grande propensão ao fechamento de todos os institutos criados após 1930. (...) Por sua vez, ele se mostra grandemente repressivo quando se trata de reivindicações populares. (...) A repressão se dá em diversos campos e ela se faz sentir desde o começo do governo Dutra. (...) A repressão contra as classes populares ocorre paralelamente à repressão aos movimentos grevistas. Desde 1945 o operariado procura, por meio da paralisação, conseguir melhoria de salários e de condições de trabalho (...). (A partir de) agosto de 1946, (as autoridades governamentais) procuram confundir o movimento grevista, em geral, com o movimento comunista. Desta maneira, a luta contra a carestia, as greves e as atividades comunistas aparecem denunciadas pela polícia como um todo." 274

Em 1947, o governo Dutra intensificou sua ação anticomunista. Essa aproximação foi conseqüência de um reordenamento das forças políticas internacionais que passavam a atuar mais de forma mais decisiva no Brasil. Era o momento da Guerra Fria e a disputa de posições mundiais entre os Estados Unidos e a URSS. Carone diz: “A oposição entre liberalidade para com a classe dominante e coerção para com o movimento trabalhador, não é simples ato arbitrário e, sim, atitude que faz parte de uma política globalizante. Antes de mais nada, há ligação entre o sentido da política brasileira e a política americana, que se traduz na maior subordinação de nossa parte aos Estados Unidos. Repetimos: há independência e liberdade da política econômica e social brasileira diante de suas próprias forças internas, o que não impede que as camadas dirigentes se subordinem cada vez mais a tendências e às pressões exteriores

${ }^{274}$ CARONE, E. A república liberal - evolução política (1945-1964). Volume II. São Paulo: Difel, 1985, pp. 20-21. 
do capitalismo americano. Desta maneira, é difícil distinguir entre os atos repressivos determinados pelos interesses das classes dominantes brasileiras e os que refletem sentido exterior (...). A razão desta subordinação está no papel que os Estados Unidos tomam no após-guerra. No nosso caso, passamos a ficar (...) (Como diria Milcíades M. Mourão:) 'engatados aos Estados Unidos. (...) A nossa política externa desde então, menos do que orientada pela dos Estados Unidos, vem a ser a da própria república americana'.,275

No Brasil, predominou a influência norte-americana e, por conseguinte, o combate ferrenho ao comunismo: "é este novo fator, o de subordinação aos interesses americanos, que vai representar um dado novo na nossa política interna. Não que as nossas classes dirigentes e nosso Exército sejam imunes ao anticomunismo, atitude que sempre cultivaram para justificar a sua política reacionária e contrária às reivindicações operárias. Mas, com a guerra e as vitórias russas, começam a surgir simpatias internas a favor do comunismo, o que impede que se adote atitude ríspida e precipitada contra este movimento. Por esta razão pode-se distinguir dois momentos da reação governamental: em 1946, ainda no calor do imediato pós-guerra, o governo procura atingir as manifestações mais vulneráveis do movimento comunista; a partir de 1947, obedecendo à lógica da guerra fria norte-americana contra a Rússia, vão-se tomar medidas radicais, como o fechamento do PCB, o rompimento diplomático com a Rússia, etc. (...) Os Estados Unidos praticam ofensivamente a sua política de guerra fria, isto é, procuram levar o mundo capitalista a romper suas relações com a Rússia, além de chegar até a ameaçá-la com a bomba atômica. Como resultado, no Chile, na França e na Itália, os deputados comunistas são cassados, há rompimento de relações diplomáticas entre vários países e a União Soviética, e os países capitalistas praticam boicote aos produtos soviéticos. O Brasil segue tardiamente esta mesma orientação, só que, a partir de 1947, sua ação anticomunista obedece a movimentos coordenados e não mais ocasionais."276

\footnotetext{
275 CARONE, E. Op. cit., pp. 22-23. Milcíades Mourão continua: "Renunciamos vergonhosamente e sem compensação válida àquela superior política diplomática merecedora do respeito e do acatamento dos povos mais avançados do mundo, para nos engalhar à de uma nação que até hoje engatinha em matéria de política e quando se levanta, é para impor, corrompendo e ameaçando. Capitulamos na defesa de todos os direitos e todos os princípios já consagrados por longa tradição jurídica e política e, sistematicamente, defendemos os interesses econômicos dos Estados Unidos, de seus trust contra nós mesmos, na suposição de se combater o comunismo (...). Nos Congressos Internacionais, o Brasil vota como autômato: não, se a posição contraria os interesses dos Estados Unidos; sim, quando favorece. Jamais discorda.” Idem, Ibidem, p. 23.

${ }^{276}$ Idem, ibidem, p. 25. Nessa época, o Vanguarda Socialista posiciona-se contra o fechamento do PCB e a cassação de mandato de seus deputados e do senador Luis Carlos Prestes. Gina Machado apresenta os motivos: “(As) severas divergências da 'Vanguarda' com relação ao PCB não impediram, no entanto, que
} 
Entre a luta da direita brasileira e os comunistas, o Vanguarda Socialista surgia como uma alternativa sem muita força e repercussão. A partir das atividades do Semanário, em 1945 e 1946, Mário Pedrosa deu continuidade, nos anos subseqüentes, a uma série de idéias muito interessantes sobre as causas - que estavam em curso no Brasil e no mundo - do processo de normalização das conquistas plásticas na arte moderna. Era o princípio de uma reversão completa no direcionamento do valor atribuído à figuração brasileira. Muito já se falou da iniciativa e do esforço pessoal de Pedrosa, em meados dos anos quarenta, para a introdução do abstracionismo em nosso meio artístico. Não há dúvida que, se pensarmos no desenvolvimento de uma tendência construtiva na arte brasileira nos anos cinqüenta, sem par nos principais centros internacionais de arte e muito menos precedentes locais, o feito foi aqui no mínimo digno de menção. Colaborou muito, para isso, a trajetória de Pedrosa nos Estados Unidos, ao passo que instruíram e impressionaram o público cultivado no Brasil - muito mais que o ensaio sobre os murais de Portinari em Washington - dois artigos sobre a obra do artista norte-americano Alexander Calder, publicados no suplemento dominical do jornal Correio da Manhã em dezembro de 1944.

Se lá, nos murais de Washington, Pedrosa revelava ainda a importância comunicativa da obra de Portinari em conjunção com a predileção de Trotski pela pintura muralista de Diego Rivera, nos ensaios sobre Calder ${ }^{277}$ o problema da comunicação estabelece-se em relação direta com os dados informados na própria obra,

o jornal defendesse o direito de associação política quando o governo, em julho de 1947, resolve cassar o registro do PCB" Cf. MACHADO, GINA G. G. Vanguarda Socialista - busca de um caminho independente. Dissertação de mestrado. Faculdade de Filosofia, Letras e Ciências Humanas da Universidade de São Paulo. Orientador: Prof. Dr. Oliveiros S. Ferreira. 1982, pp. 51-52. (parênteses nossos). Portinari foi também perseguido pela polícia, devido às suas atividades como militante do PCB. Moreira relata: “A partir de 1947, a situação do Partido Comunista começou novamente a piorar. No Rio (de Janeiro) foi aberto um inquérito contra os intelectuais que tinham ensinado na Escola do Povo, entre os quais, Portinari. A animosidade contra os comunistas cres cia diariamente e várias vezes Candim teve que ir depor na polícia. Por isso, resolveu viajar para o Uruguai, onde, em breve, iria fazer uma exposição. (...) Em Montevidéu, Portinari ficou quase um ano com sua família. Além de fazer uma exposição, pintou na capital uruguaia, em 1948, o painel histórico "Primeira Missa no Brasil”. Em Buenos Aires, Candim expôs na Galeria Peuzer (...). Candim regressou a seu país ainda em 1948, no mesmo ano em que os mandatos dos comunistas eleitos foram cassados e o Partido Comunista caiu novamente na ilegalidade. Nunca abandonou oficialmente o partido, embora não tenha conseguido mais se adaptar aos esquemas partidários e aos poucos se tenha desligado de qualquer atividade militante. Não admitiu nunca, também, qualquer interferência em sua arte, a verdadeira razão de sua vida." MOREIRA, M. Cândido Portinari In "A vida dos grandes brasileiros". São Paulo: Editora Três Ltda., 2003, pp. 97-98. (parênteses nossos). A conclusão de Moreira enfatiza a filiação ética de Portinari ao PCB e sugere discordância com a linha oficial do partido para as artes. Talvez Portinari não se entregara ao realismo acentuadamente propagandista devido a seu ecletismo como pintor, mas isso se deveu também ao fím da escalada política do Partido no país, quando esse foi lançado na ilegalidade.

277 Os ensaios sobre Alexander Calder são: "Calder, escultor de cata-ventos" e "Tensão e coesão na obra de Calder”. Segundo Otilia Arantes, ambos foram redigidos em Nova York, por ocasião da primeira exposição de Calder, e publicados pelo Correio da Manhã em 1944. 
pela sua fatura mais livre e desarraigada do âmbito discursivo, verbal. Segundo Pedrosa, estava claro que a mistificação do elemento nacional ou a preocupação excessiva com o elemento social, traduzidos na ênfase do tema em pintura, reafirmavam a dimensão política direcionadora e, por conseguinte, ideológica da arte. A solução desse impasse foi dada por sua opção, a partir de 1942, pela tendência que reagia "às limitações da pintura a óleo (...) (quando) os artistas europeus resolveram o impasse, decidindo-se a fazer sua revolução estética (através da análise pictórica) ali dentro do quadro a óleo". ${ }^{278}$ Não se tratava então de uma preferência pela escolha de suporte - tela ou muro -, mas pela escolha entre a influência do elemento discursivo nas artes plásticas e as características próprias delas, como alternativa para vitalizar mais uma vez as forças cognitivas presentes na arte moderna.

Portinari era, sem objeção, o grande nome da arte moderna brasileira naquele instante. Havia a impressão, generalizada e difundida nos meios cultos, que ele fora um dos únicos artistas capazes de encontrar o elo entre conteúdo e forma, entre a relevância dos aspectos intrínsecos da especificidade cultural do país e a expressão moderna. Isso tudo a despeito das críticas que recebeu por ter se filiado ao Partido Comunista do Brasil. Se o interesse de Mário Pedrosa pela obra de Alexander Calder indicava uma nova direção possível para a arte moderna no plano local, era forçoso o acerto de contas com a tradição realista representada pelas obras de Portinari. Ainda que, no ensaio de Washington, não houvesse uma crítica incisiva de Pedrosa aos murais do Pintor - até mesmo por ter encontrado neles uma disposição maior para o trabalho livre da forma em oposição às exigências do conteúdo -, começava ali, um percurso de análise crítica dos elementos estruturais na produção artística que se reunia à valorização de sua autonomia. Aquele acerto entre o significado histórico da obra de Portinari e o interesse enfático de Pedrosa pela arte independente viria mais adiante, em um futuro próximo.

Após sua saída do semanário Vanguarda Socialista, surgiu a ocasião favorável para que Mário Pedrosa retomasse suas considerações sobre a obra de Portinari. Afinal de contas, o Pintor recebera a incumbência de executar um painel no edifício do Banco Boavista, projetado por Oscar Niemeyer. Nesse ensaio de 1948, intitulado "A missa de Portinari", o Crítico interessou-se sobremaneira pelo tratamento especial dado no painel à luz e ao modelado. Ao contrário do que se poderia pensar, Pedrosa não fez análise e descrição direcionadas com exclusividade ao figurativismo, pois se tratava mais de pôr

\footnotetext{
278 PEDROSA, M. "Portinari - de Brodósqui aos murais de Washington” In Dos murais de Portinari aos espaços de Brasília. São Paulo: Perspectiva, 1981, p. 13. (parênteses nossos).
} 
em dúvida seus elementos de sustentação. Tanto a luz como o modelado serviam de ponto de partida comum, todavia em sentidos opostos, à obediênc ia das leis acadêmicas de composição e ao desenvolvimento de uma linguagem expressiva com influência da Escola de Paris. Dessa escola, era preciso alertar em particular para o legado do cubismo, em termos de redimensionamento espacial e de relatividade dos esquemas representativos tradicionais, mas também pôr à prova sua influência na obra de Portinari.

Pedrosa queria situar o painel "A primeira missa no Brasil" entre suas influências mais sintomáticas, a fim de conseguir uma análise de grande alcance que levasse em conta os dois horizontes ajustados na atuação criativa de Portinari. Numa direção, tínhamos o tema da Primeira Missa executado por Vítor Meirelles, pintor da Academia Nacional de Belas-Artes, noutra, o mestre espanhol da Escola de Paris, Pablo Picasso. De fato, a pintura de Portinari achava-se ainda, no final dos anos quarenta, a meio caminho de sua formação como artista acadêmico e de suas retificações modernas introduzidas ao longo da carreira. Assim, pela análise dos ajustes propostos pelo Pintor brasileiro para essas duas tradições, introduzia-se em último termo uma avaliação ampla sobre a atualidade ou não do direcionamento dado à própria pintura moderna brasileira. Isso sem discutir o mérito expressivo e peculiar da obra de Portinari - quase sem par na produção artística internacional -, enquanto se definia sua limitação histórica e o desenlace criativo do impasse vivido pelo Pintor.

Quando escreveu o ensaio sobre o novo painel em 1948, Pedrosa parecia acreditar numa guinada de Portinari para o cultivo aprimorado das referências cubistas e dos elementos puros, em busca de uma expressão cada vez mais autônoma da arte. O fato é que havia indícios fortes de uma viragem possível na produção do Pintor, acompanhada, por Pedrosa, a partir dos murais para a Biblioteca do Congresso em Washington. Chegava-se ao tema da Primeira Missa com a sensação de que o naturalismo ou a referência neoclássica da tradição pictórica do século XIX tinham sido ultrapassados, se não por completo, ao menos em grande parte. A pungência e a fixidez do assunto ou tema na pintura não diziam respeito apenas à obra de Portinari, mas às discussões gerais sobre arte contemporânea por via das exigências contínuas da filiação política e do comprometimento social. A saída da referência direta ao plano imperativo do discurso verbal estava contida justamente na aposta sobre as questões específicas da forma e no desvencilhar a análise crítica da escolha pela adaptação da forma ao conteúdo. 
Se a versão acadêmica na "Primeira missa no Brasil" de Vitor Meirelles subordinava a forma ao conteúdo, enquanto mantinha a pintura atrelada à representação de uma realidade pressuposta, a versão de Portinari seguia um outro caminho. Na pintura acadêmica do século XIX, esmiuçavam-se os detalhes da natureza e dos costumes, com o intuito de permitir uma descrição fidedigna e um reflexo atualizado do momento em que se realizou o evento histórico. Nela se garantia um trânsito livre entre o modelo de vida - e inclusive de percepção - ocidental e a terra recém-descoberta, em que se dava como preexistentes as condições para que se introduzissem aqui tanto os procedimentos como o substrato da religião cristã. Tratava-se apenas de converter os indígenas. Já na pintura de Portinari, “essa suposta realidade histórica não existe” e, acrescenta Pedrosa, "tampouco preocupa-se ele com as descrições da carta de Pero Vaz", ${ }^{279}$ pois não se reunia um elenco de atributos naturais e de motivos exóticos ou excêntricos com o intuito de melhor falsificar uma unidade de mundo. A verdade da obra de Portinari não estava na representação fidedigna da realidade, tal como vista em um esquema perspético, mas na destruição de seu caráter natural e na destruição da suposta verdade do acontecimento histórico.

A "Primeira Missa" de Portinari desalojava o mito da fundação ecumênica e revelava seu significado oculto. Em contraposição à falsa entonação do modelo universal na percepção e na sociedade, desvelava-se sua imposição com a abertura, feita por cima, de um outro contexto social no início da história do Brasil. Consistia nessa ruptura com a transposição literal da verdade do acontecimento histórico na pintura, em relação infensa aos objetivos inscritos na tradição acadêmica, a grande contribuição do Pintor. Seu cultivo mais amplo e acentuado da liberdade intrínseca na elaboração plástica, que se distanciava dos motivos naturais, permitiu a evidência da falsidade no relato histórico. Daí o desvelamento - ainda no campo estrito do conteúdo proporcionado pela obra: "A missa de Portinari é um ato de conquista cultural, de plantação de semente na terra virgem. Aquilo tudo vem de fora; é um enxerto de civilização cristã em solo pagão. Eis por que não há índios, não há árvores, não há morros nem bichos a participarem da cerimônia que só estrangeiros, brancos de outros

\footnotetext{
${ }^{279}$ PEDROSA, M. “A missa de Portinari” In Acadêmicos e Modernos, (org. Otília B. F. Arantes). São Paulo: EDUSP, 1998, p. 165. Aqui seguimos indicações da análise de Otília Arantes. Cf. ARANTES, O. B. F. Mário Pedrosa: itinerário crítico. São Paulo: Cosac Naify, 2004, pp. 27-49.
} 
mundos, talvez de outra espécie, estão realizando. Aquela missa ainda é coisa de brancos., 280

Para Mário Pedrosa, o marco divisório entre as exigências naturalistas na pintura, em conformidade com o modelo tradicional de civilização, e o entusiasmo pela independência intrínseca dos elementos artísticos, constituía o principal a ser destacado na "Primeira Missa" de Portinari, ao contrário de seu conteúdo contestador separado da forma que o criou. Essa autonomia crítica instaurada pela arte moderna deveria ser acentuada, de forma que o Pintor fosse capaz de superar o velho modelo de civilização pela ação renovadora da percepção e não pela visibilidade do excêntrico. Isso porque, se se deslocava o centro de atenção sem uma alteração de sua lógica de funcionamento, não se tinha uma transformação profunda. Não foi em outro sentido que Pedrosa ressaltou o aspecto artificial da luz e da cor, da construção e da ambiência dos personagens na composição de Portinari, como instante de consciência do processo histórico e como estratégia para desvincular a manifestação artística das peias do modo de vida e do pensamento dominantes. O tratamento dado à luz e à cor convergia para a revolução estética da percepção e indicava sua função originária e indispensável na almejada mutação social.

Como alternativa à abordagem da luz e do ambiente nos modos franceses ou nos seus correlatos europeus, Portinari não se fixou na pesquisa da cor e da luz locais, como havia feito muito tempo antes Almeida Júnior, mas procurou enfatizá-las em sua integridade como elementos reunidos ao aspecto estrutural da pintura. O Pintor distribuía as cores nas áreas de formas geométricas e de modelado dos personagens, criava relações dinâmicas entre essas áreas de cor e as de luz e vertia o ambiente estático das cenas convencionais em uma pluralidade de planos ou lugares descentrados; ademais, a iluminação seguia a desconcentração da atenção em um só pólo. A partir daí, consolidava-se um ponto de não retorno à concepção acadêmica da arte, como espelho da realidade. Conclui Pedrosa: “Tendo jogado fora todo esse lastro de pseudoproblemas pictóricos, (...) toda atenção convergiu para as personagens que participavam do sagrado ritual. O local em que este é celebrado ficou por isso mesmo perfeitamente delimitado como se fosse palco, com sua luz própria, artificial e distribuída pelo soberano arbítrio do artista. Daí não haver um sistema só de iluminação, nem sua solução se fazer uniformemente, de acordo com as regras tradicionais."281

\footnotetext{
${ }^{280}$ PEDROSA, M. Op. cit., p. 165.

${ }^{281}$ PEDROSA, M. Op. cit., p. 165.
} 
Todo o painel da "Primeira Missa" divide-se em dois, a partir de uma linha vertical oculta e centralizada sob um cálice alçado aos céus pela mão de Frei Henrique de Coimbra. Ora as cores livres disputam em intensidade, ora se combinam em ajustes perfeitamente harmônicos nos planos geométricos e nas figuras. Um dos efeitos mais importantes alcançados pelo Pintor com as cores e com as tonalidades escuras e claras foi a separação da obra em planos. O jogo das cores coordenava uma iluminação de parte a parte. Primeiro, um plano em que predominam as cores marrom, roxo, vermelho rubi e bordeaux, azul ultramarinho. Esses tons escuros tornavam ainda mais etéreo ou celestial o segundo plano em profundidade. Nele, predominava a cor ocre para o branco. Além dela, o amarelo - referido por Pedrosa às tradições cristã e chinesa - expandia-se para fora na direção do olho do espectador e para dentro do painel para o reforço das impressões atmosféricas, que enlevavam a cerimônia conduzida por Henrique de Coimbra e seus congregados. Por último, o terceiro plano - com variedade de tons agrupados e alternados entre escuros e claros - estabelecia um limite horizontal para a atmosfera do segundo plano e, ao mesmo tempo, permitia a ascese da luz através de um triângulo cujo ápice encontrava-se no limite superior do painel e a base na linha de divisão entre o primeiro e o segundo planos.

De modo geral, as referências secundárias de lugar ou de espaço naturalista foram suprimidas da "Primeira Missa" de Portinari, com o objetivo de se impelir a atenção do espectador para o ritual sagrado, para a ascese religiosa através da luz. Toda a construção dos planos obedece a esse imperativo. Também, o interesse pela transmutação dos materiais pictóricos em sentimento espiritual ajustava-se à pesquisa da cor e da forma afastadas da referência direta à natureza. Em sua totalidade, a pintura recebeu uma divisão geométrica para abrigar áreas de cor, o que ressaltou uma predileção bem marcada por toda espécie de formas artificiais. Com exceção das serras, instaladas no horizonte da pintura (terceiro plano), as linhas curvas não foram utilizadas - como salientava Pedrosa -, a não ser aquelas acessórias para a composição das figuras. Já as linhas retas enfatizam a força do movimento luminoso para o alto e constituem tanto a divisão interna das partes do painel como o fator de unidade entre os conjuntos de figuras dispersos. Decorre disso que a cena construída lidava com a relação desigual entre o aspecto figurativo do tema e a delimitação geométrica das áreas de cor, estabelecida na estrutura da obra.

Se a obra de Pablo Picasso exerceu forte influência na pintura de Cândido Portinari, é preciso dizer que uma das diferenças mais evidentes entre os dois foi o 
tratamento dado à figura. Como se sabe, o pintor espanhol utilizou-se da deformação geometrizada da figura como marca de seu trabalho. Visava com isso interromper a referência pictórica e mesmo cultural da tradição greco-romana no Ocidente. Muita vez, a deformação picassiana trazia consigo a síntese temporal de um ou mais aspectos espaciais do objeto. Um dos exemplos mais conhecidos dessa prática foi a figura recorrente da cabeça representada pela junção da aparência frontal com a de perfil (1/3 da face e $2 / 3$ do perfil) - o touro, o cavalo e os homens foram executados dessa forma em Guernica de 1937. Assim, Picasso interessou-se muito mais em sua carreira pela perscrutação do objeto como meio de análise e de síntese da concepção de tempo e de espaço do que com a corporeidade das figuras, ainda que não seja difícil encontrar exemplares dos anos trinta em que o pintor espanhol se dedicou à feitura de volume para os corpos. Nessa direção encontra-se Portinari, que se preocupou sobretudo em manter uma referência sempre forte entre suas figuras e a realidade, entre a representação e o mundo. Para isso, propunha a adequação entre formas geométricas e as figuras modeladas do tema.

Dessa forma, o modelado foi uma das principais características da obra de Portinari em relação a Picasso. O modelado surgiu, na obra de Portinari, da necessidade de manter o lastro entre o movimento de composição e decomposição geométrica e a referência ao tema - à realidade que sustentava sua obra. Por assim dizer, o pintor brasileiro havia estabelecido um equilíbrio difícil entre decomposição geométrica e corporeidade da figura. Segundo Pedrosa, a solução plástica fora encontrada nos Estados Unidos e fazia-se agora presente na "Primeira Missa": amainar, ininterrupta e gradativamente, a evidência do claro-escuro ou do volume nos corpos para que fosse mais congruente a passagem entre a predominância geométrica da composição e os grupos de figuras. Comenta Pedrosa: “A sugestão de volume é, em toda a composição, extremamente sóbria, mal dando para tornear levemente alguns corpos, como o do grande soldado ereto, de lança na mão, a guardar a entrada do quadro pelo canto esquerdo. Esta figura, pelo tratamento e atitude, vem de outros painéis, inclusive de um dos de Washington. (...) As próprias colunas são planas, sem qualquer notação do modelado."282

A adoção da iluminação cubista era o grande trunfo na "Primeira Missa" de Portinari. Com isso, ele conseguira superar o equilíbrio precário entre formas

${ }^{282}$ PEDROSA, M. Op. cit., p. 166. 
geométricas e figuras humanas, pois a partição dos objetos em áreas de sombra e áreas de luz - inventada pelos cubistas - prescindia do claro-escuro e desconsiderava o recurso ao modelado nas figuras. Se a Portinari interessava diminuir a importância da corporeidade das figuras em sua pintura, isso significava uma mudança de rumo ou a inauguração de uma pintura menos afeita à reprodução fiel da realidade. Mesmo que essa suposição não se confirmasse de todo - pensava Pedrosa - a "Primeira Missa" estava pelo menos um passo adiante dos trabalhos da fase recente sobre os retirantes. Assim disse Pedrosa: "O mestre brasileiro não carece de truques para impor-se ou ser compreendido. Ele está agora diante do caminho que ainda tem de percorrer, sozinho. A solução que acaba de dar a um gênero histórico como o da primeira missa é prova de seu poder criador. Resolutamente, ele suprimiu uma série de problemas falsos, como o da luz natural, da realidade histórica etc. Foi mais longe, e suprimiu a natureza do tema que devia transpor para a tela. Era o seu direito. E apresentou a solução de modo magistral.",283

Ao romper com a preceptiva da luz natural e apoiar-se na iluminação artificial para decomposição das figuras, Cândido Portinari afastava a importância atribuída ao aspecto escultórico de suas figuras, à corporeidade em sua obra. Para Pedrosa, o equilíbrio até aqui precário entre a figura modelada e a forma geométrica estava para irromper na liberdade da pintura em relação ao tema ou à função descritiva da realidade. Ele entrevia, na "Primeira Missa", o alvorecer de uma nova fase de Portinari, cuja característica principal era a substituição da dramaticidade da cena pela pesquisa da estrutura e dos elementos constituintes da pintura. Certamente, havia alguns deslizes cometidos pelo pintor brasileiro ainda à cata de perfectibilidade descritiva na cena: "um chapéu da segunda figura ajoelhada à direita, como a lista da mesma cor da túnica do soldado no lado oposto, não precisava nem concretizar-se, signo já tão banalizado com a bandeira da Cruz Vermelha. Mas como já estamos longe dos excessos pueris das lágrimas de cimento armado da série dos retirantes!"284

A "Primeira Missa" de Portinari distanciava-se da função descritiva por encontrar uma solução plástica afinada aos aspectos estruturais da arte moderna. Nela, o pintor tomava distância em relação aos acontecimentos ou à fidelidade do relato histórico e dava continuidade à via de análise dos elementos intrínsecos da obra, com respaldo nos avanços dos cubistas em matéria de cor e de luz, do plano pictórico e da

\footnotetext{
${ }^{283}$ PEDROSA, M. Op. cit., p. 170.

${ }^{284}$ Idem, ibidem, p. 170.
} 
forma. As conseqüências dessa ênfase eram evidentes, haja vista a importância que o tema ou o assunto teve não somente na obra de Portinari, mas também na eleição - pela primeira geração de intelectuais do Modernismo Brasileiro - do procedimento cubista como fonte inspiradora e propícia para uma compreensão mais atenta sobre a essência da identidade brasileira. Além disso, o distanciamento do tema na pintura introduzia outros parâmetros sobre a finalidade comunicativa da obra - na relação entre arte e público. A negação desses dois aspectos, implicados na preponderância do conteúdo na obra de arte, apontava não menos uma nova fase de Portinari que o início de um outro período da arte moderna no Brasil.

No momento em que Mário Pedrosa avaliou a insistência da pesquisa artística intrínseca de Portinari sobre o conteúdo histórico da "Primeira Missa", como um desenvolvimento positivo das artes plásticas, ele tomava posição frente ao legado do Pintor. Restava saber, então, se as mudanças efetuadas por Portinari estavam ou não impressas em uma tendência comprometida em estabelecer um outro curso para a arte moderna brasileira. Se elas fossem duradouras a resposta seria afirmativa. Por mais que a proposição e o resultado da iluminação artificial na "Primeira Missa" indicassem uma libertação dos cânones tradicionais, era uma exigência muito severa pretender que Portinari enveredasse pela expressão artística inteiramente livre e descompromissada com a atividade comunicativa simples entre a obra e o público. Estava além das forças dele compreender a invenção cubista como algo mais que a possibilidade de dar visibilidade e voz para tudo aquilo que, entre nós, era excêntrico à tradição da cultura ocidental e que, até o advento da arte moderna, tinha sido completa e propositalmente obscurecido.

Intelectuais e artistas, como Portinari, valiam-se da conquis ta do descentramento perceptivo - e cultural - como forma de valorizar e ao mesmo tempo fundar um ponto de vista menos afeito aos disfarces sobre a realidade social do País e mais afinado com nosso modo de ser. Essa atitude tinha-se consolidado na arte moderna brasileira. Por um instante, pensou-se que as experiências dos cubistas - com modelos perceptivos não dominantes - vinham fornecer a chave de interpretação estética do Brasil. Ela apoiavase em uma visibilidade inédita sobre o pormenor da matéria social local - há muito tempo deixada de lado - que concorria com as expressões atualíssimas da arte. Dessa forma, a libertação - feita por baixo - do jugo estético acadêmico era o princípio de uma transformação não apenas dos valores, mas também das próprias bases da velha civilização ocidental. Pela primeira vez, existiam forças para o impedimento da 
transposição direta do ponto de vista social e estético vindo de fora, inaugurando a consciência da especificidade brasileira e sua atualidade como expressão estética.

Essa consciência social e artística era a combinação entre um novo modelo de civilização internacional, derivado das conquistas inéditas da arte moderna no plano da forma, e também do interesse pela matéria brasileira. Daí em diante, a atuação renovadora da arte moderna internacional iluminava a consciência sobre o Brasil e viceversa. De fato, o que significou um avanço temporário na arte moderna brasileira, por força das circunstâncias nos anos trinta e quarenta, recaiu na predominância crescente do conteúdo sobre a forma, na relevância dada ao aspecto da especificidade em consonância com o desenvolvimento subterrâneo e contínuo das tradições artísticas baseadas no realismo social ou político. Com o advento da arte moderna, o problema da consciência sobre a sociedade e a arte estava em parte resolvido e em parte não. Isso porque, muita vez confundiu-se o caráter e a contribuição inovadora da arte com a premência pela descrição política e social. Esse problema foi avaliado por Pedrosa não somente no surgimento de uma tendência naturalista ou estabilizadora na arte moderna, mas também na afirmação de uma identidade cultural brasileira. Sua solução exigia um compromisso com todo potencial criativo das atividades culturais excêntricas ou exóticas em um novo sentido, que considerasse as expressões artísticas mais atuais aliadas à manifestação de uma nova percepção sobre a arte e sobre o mundo.

Não há dúvida que, nos idos de quarenta, o problema plástico principal de Portinari ultrapassava a expressão simples das características peculiares de representação do ambiente brasileiro. O painel da "Primeira Missa", em 1948, comprovava a afinidade cada vez maior entre o processo criativo do pintor brasileiro e o recurso cubista de análise e de descentramento na cons trução plástica. Contudo, o passo original a ser dado por Portinari era, em vez da insistência na expressão artística que fosse a valorização do excêntrico perceptivo na medida em que ele priorizasse apenas o elemento social, renunciar à redundância dessa falsa alternativa e apostar verdadeiramente no avesso do modelo sócio-cultural dominante. Nessa altura dos acontecimentos, não se tratava mais de encontrar as raízes da cultura brasileira nem de oferecer um ponto de vista privilegiado na obra sobre os trabalhadores e os deserdados da terra, mas de reafirmar o grande objetivo que impulsionou o surgimento da arte moderna em seu compromisso com a mutação social profunda através da percepção.

Em agosto de 1949, Mário Pedrosa pôde avaliar o grau de acerto de suas considerações sobre a obra de Portinari, a partir do novo painel sobre a saga de José 
Joaquim da Silva Xavier. Cândido Portinari continuava fiel à sua linha de pesquisa plástica que tentava conciliar recursos expressivos da arte moderna com a via realista. Mais ainda, ele mantinha-se realmente fiel ao seu ideal político, com prejuízo da qualidade estética. Tudo o que fora motivo de entusiasmo para Pedrosa desfez-se, pois tanto a solução plástica proposta na "Primeira Missa" não teve continuidade quanto voltava à carga o desenvolvimento do tema político como objetivo principal na pintura histórica sobre Tiradentes. Estava evidente a continuidade do interesse pela pintura de gênero que se adequava perfeitamente à subordinação da forma ao conteúdo. O Pintor valia-se do expediente de compor o painel segundo sua avaliação política sobre o famoso tema da história nacional, enfatizando a idéia da Libertação Nacional. 


\section{$\underline{\text { O Tiradentes de Portinari e a mítica brasileira do herói nacional }}$}

O fechamento do PCB e a cassação do mandato de seus deputados federais bem como do senador Luís Carlos Prestes, respectivamente em maio de 1947 e janeiro de 1948, assinalaram a cooperação do Brasil com a política norte-americana na Guerra Fria. Carone comenta: “(Eurico Gaspar Dutra) envia o Projeto 900-A para publicação, considerando extintos os mandatos comunistas e em 10 de janeiro a Câmara dos Deputados, em face das medidas anteriores, cassa os mandatos de Carlos Marighela, Francisco Gomes, João Amazonas de Souza Pedroso, Maurício Grabois, Agostinho Dias de Oliveira, Alcedo de Morais Coutinho, Gregório Lourenço Bezerra, Abílio Fernandes, Claudino José da Silva, Henrique Cordeiro Cest, Gervásio Gomes de Azevedo, Jorge Amado, José Maria Crispim, Osvaldo Pacheco da Silva. O mesmo se dá no Senado Federal, com Luís Carlos Prestes. Logo depois o fato se repete nas Câmaras estaduais. (...) A cassação também atinge os jornais comunistas, como a Imprensa Popular, no Rio de Janeiro, Hoje, em São Paulo, e outros órgãos editados nos Estados. Paralelamente, a partir de fevereiro de 1948 é pedida a prisão preventiva de Luís Carlos Prestes (...). A partir de 1948 uma nova situação se apresenta ao partido.,285

Membros e militantes do PCB continuaram suas atividades políticas na clandestinidade. Prestes e a cúpula do partido lançaram conjuntamente o "Manifesto de Janeiro" em 1948. Nele, havia uma nova linha a ser seguida: “(o partido não segue mais a linha de) coexistência pacífica, fase que acaba de se encerrar, mas o que, na verdade, pode ser denominado de classe contra classe. O Manifesto inicia linha política que persiste até 1958, e no seu documento inicial Prestes assinala a diferença entre os anos de 1945 e o atual: o primeiro é de 'ascenso democrático'; 1946 e 1947 são momentos em que 'acumularam-se os golpes contra as conquistas democráticas'; as classes dominantes, por sua vez, passam por um momento de crise, vivendo dentro dos 'limites de sua estrutura econômica atrasada, semifeudal e semicolonial'; e o governo é de 'traição nacional', 'a serviço do imperialismo americano'. A submissão governamental ao imperialismo é ato de subserviência, enquanto seu anticomunismo representa "máscara da reação para encobrir sua política de traição nacional". Essas contradições das autoridades e das classes dominantes - levam a uma ofensiva reacionária, que

${ }^{285}$ CARONE, E. A República liberal - instituições e classes sociais (1945-1964). Volume I. São Paulo: Difel, 1985, p. 348. 
resulta em ataque à classe operária, da cidade e do campo. A frente comum das forças reacionárias - união do PSD-PTB, agora com o apoio da UDN a Dutra que, por sua vez, conta com o apoio do Exército -, como conseqüência torna inevitável 'um mais rápido ressurgimento do fascismo no país', „286

Para o PCB, a alternativa política contra o governo antidemocrático de Dutra e contra o imperialismo era a organização de movimentos populares, que lutariam por conquistas imediatas e se tornariam com o tempo um movimento de oposição ao governo. Prestes apresenta seis motivos pelos quais formar-se-ia um amplo movimento de oposição ao governo: "1) a defesa da independência nacional contra a intervenção imperialista e o plano Truman, assim como a defesa de nossas riquezas naturais, (...);2) a defesa das liberdades populares e das conquistas democráticas que o governo procura de todas as maneiras eliminar; e, ao lado disso, a luta pela liberdade dos perseguidos políticos, presos e condenados; 3) a defesa do nível de vida das massas trabalhadoras, contra a desvalorização do cruzeiro e o mercado negro, em defesa do poder aquisitivo do salário, contra a carestia da vida; 4) a defesa dos interesses dos camponeses, desde os colonos e arrendatários até os sitiantes e pequenos proprietários por meio de melhores condições de arrendamento, contra os impostos crescentes (...); 5) a defesa da indústria nacional contra a concorrência imperialista, pela industrialização do país e maior facilidade de créditos aos pequenos e médios industriais; 6) a defesa do povo contra a injustiça, a desigualdade crescente, a corrupção, todas as forças enfim de exploração econômica e demagógicas que visam impedir qualquer medida que leve à reforma da estrutura econômica do país (...).,287

Nessa época, o PCB pretendia tirar do poder a classe dominante, "feudal

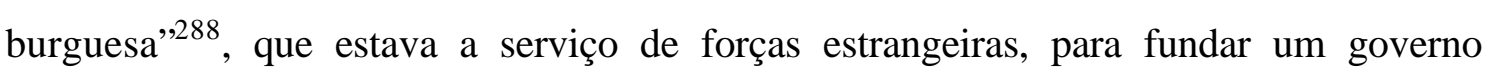
popular, representante de todas as classes sob a direção do proletariado, representado

\footnotetext{
${ }^{286}$ CARONE, E. Op. cit., p. 349. A solução, para o PCB, era o levante revolucionário: "Diante dessa situação é preciso 'lutar levantando com coragem e audácia a solução dos problemas fundamentais da revolução agrária e antiimperialista em nossa Pátria', isto é, a sua base econômica. 'É com esse programa positivo, visando à solução dos problemas da revolução agrária e antiimperialista, que conseguiremos mobilizar as massas a fim de que resistam à reação e lutem pela derrubada do atual governo de traição nacional, pela instauração no país de um governo popular, democrático e progressista, único capaz de salvar o país da miséria, do aniquilamento, da perda total de sua soberania'. (...) Assim, a 'unidade popular e democrática' é o fator dinâmico para a ação política que o partido põe em prática." Idem, ibidem, p. 350.

${ }^{287}$ CARONE, E. O PCB (1943-1964). Volume II. São Paulo: Difel, 1985, pp.88-89. (parênteses nossos). Em decorrência do "Manifesto de Janeiro" e da atuação política dos membros do PCB, nasce a Frente Democrática de Libertação Nacional no segundo semestre de 1950.

${ }^{288}$ Cf. PRADO, C. Jr. "A natureza econômica da colonização tropical" In O marxismo na América Latina - uma antologia de 1909 aos dias atuais. (organizador: Michel Löwy). São Paulo: Fundação Perseu Abramo, 1999, pp. 235-236.
} 
pela burocracia estatal. Um legítimo governo de Libertação Nacional. Seguindo essa nova linha política foi que muitos membros e militantes se manifestaram publicamente nos anos de 1948 e 1949. Entre eles, Portinari. O pintor tinha sido encarregado, pelo arquiteto Oscar Niemeyer, de pintar um painel para o Colégio Cataguazes. Em homenagem ao Estado de Minas Gerais, onde o colégio estava situado, e à sua história política, Niemeyer e Portinari decidiram que um painel histórico sobre Tiradentes seria muito apropriado. Ocorre que, na escolha da temática da obra, Portinari compôs intencionalmente um paralelismo entre a trajetória do herói inconfidente, que tentara libertar o Brasil do jugo colonial, símbolo da construção de uma nação livre e independente, e a luta travada naquele momento, a qual o partido comunista indicava como a principal e decisiva: contra a elite econômica e política do país e contra o imperialismo norte-americano. Acresce-se, a isso, o fato pouco conhecido e inusitado de que, na evocação do herói nacional como assunto principal do painel, Portinari retratou Luis Carlos Prestes como Tiradentes em uma das cenas da narrativa. O painel expressava a mítica do líder revolucionário, identificado com a causa do povo opresso.

Quando "Tiradentes" foi exposto para apreciação pública no Rio de Janeiro, causou enorme sucesso e muitos críticos de arte consideram-no a obra que mais expressava destreza e maturidade na carreira de Portinari. Entre esses críticos, encontravam-se militantes do PCB, tais como Astrogildo Pereira e Ibiapaba Martins. Em 13 de agosto de 1949, o jornal do partido comunista em São Paulo, Voz Operária, lançou o artigo "Tiradentes - um herói do povo que é símbolo e exemplo de lutador". Nele se fazia o elogio da obra de Portinari e se enfatizava o tema da libertação nacional, subsumido na trajetória da figura política de Tiradentes, como grande aprendizado para as camadas populares. Era uma pintura que sumarizava os anseios das camadas populares. O jornal dizia: "Pela primeira vez no Brasil, uma obra de arte desperta interesse entre o povo e chama a atenção dos trabalhadores. Trata-se do novo mural de Cândido Portinari atualmente em exposição no Automóvel Clube do Brasil, no Distrito Federal. Feito (...) (para) um Colégio de Cataguazes, Minas, o 'Tiradentes' de Portinari representa um sentido de renovação da arte pictórica brasileira, aproximando-a do povo. Aliás, a evolução de Portinari tem se feito nesse sentido desde seus trabalhos no Ministério da educação, focalizando os trabalhadores do café, do algodão, do fumo, do 
açúcar, os faiscadores de ouro. É o mundo do trabalho, a opressão, a pobreza, a miséria.",289

Exaltando as qualidades plásticas de Portinari, o artigo deslinda o significado do tema do painel e seu encadeamento narrativo: "Em 'Tiradentes', Portinari abraça um tema político e o apresenta corajosamente em toda a sua dramaticidade. Sua arte se enriquece em vez de amesquinhar-se (...). O novo (painel) (...) de Portinari é o heroísmo de um homem que traduziu num dado momento os mais sagrados anseios de libertação de um povo - o povo brasileiro. Tiradentes é o herói inconfundível que se coloca à frente de uma luta de libertação nacional e até o último sacrifício se conserva fiel a suas idéias. (...) (A seguir, o artigo descreve os valores morais do herói nacional:) Portinari consegue apresentá-lo como ele realmente foi: a própria encarnação da coragem e da dignidade. Enquanto outros se acovardam ante os agentes colonizadores europeus, Tiradentes se mantém impávido, toma a si a responsabilidade do movimento libertador e emancipador do País, sabendo de antemão que os algozes que oprimem o povo brasileiro não vacilarão um momento em mandá-lo para a forca. Sua convicção é bastante profunda para que os suplícios de uma prisão e finalmente o espectro de um cadafalso o intimidem. (...) Essa extraordinária firmeza está inconfundivelmente impressa na pintura de Portinari desde sua apresentação no grupo dos inconfidentes, na leitura da sentença de condenação, até a própria expressão da face depois do esquartejamento."290

“Tiradentes" de Portinari é uma metáfora visual do povo opresso. Segundo o artigo, a saga do herói inconfidente descreve a tomada de consciência progressiva do povo e, por fim sua libertação. Primeiro, as mulheres que simbolizam a nação aguilhoada, depois o povo que se identifica com a causa do mártir e que decide lutar, por fim a vitória do povo: "Aspecto importante de se notar neste (...) (painel) de Portinari é que Tiradentes se confunde aí com o próprio povo, é ele mesmo o povo brasileiro aguilhoado pelo explorador europeu. Quando Tiradentes aparece na tela, já está precedido de um grupo de mulheres acorrentadas simbolizando a nação brasileira oprimida pelo estrangeiro. Depois do esquartejamento, os escravos junto à carreta em que estão os despojos do herói mostram na fisionomia que a luta apenas começa e que a repressão feroz não conseguirá esmagá-la. (...) Portinari não temeu (...)

\footnotetext{
${ }^{289}$ s. a. "Tiradentes - um exemplo do povo que é símbolo e exemplo de lutador" In Voz Operária, São Paulo, 13 de agosto de 1949. (parênteses nossos).

${ }^{290}$ Idem, ibidem. (parênteses nossos).
} 
susceptibilidades: apresentou o suplício de Tiradentes em toda a sua crueza, com um senso de tragédia que se pode chamar de clássico, shakespeareano, no sentido de que convence, impressiona e grava-se para sempre. (...) Portinari (...) exprime as esperanças do povo e uma inabalável determinação de luta. Junto ao poste com a cabeça de Tiradentes um grupo de retirantes expressa solidariedade ao heroísmo do mártir. (...) na última parte do mural não só a expressão fisionômica e o próprio colorido representam a vitória do povo sobre a ignominiosa opressão estrangeira."291

O interesse da Voz Operária pela pintura de Portinari estava em sua atualidade. "Tiradentes" expressava os ideais de uma nação independente e de um povo livre: "(A pintura de Portinari) não apresenta apenas um fato histórico: é também exemplo de luta e confiança nas novas forças impulsionadoras do progresso humano. Na história uma luta como a de Tiradentes é apenas uma etapa na evolução de um povo. Outras etapas se sucederam e se sucederão. Quer dizer a luta continua. (...) A estupidez e a ferocidade com que agem hoje as classes dominantes em nosso país (...), tentando conservar à força uma ordem de coisas putrefatas (...). Os processos imundos contra os dirigentes das forças progressistas continuam. A luta pelo progresso e o bem-estar do povo são ferozmente reprimidas e se não existem forças e encenações públicas de esquartejamentos, funcionam as metralhadoras e abrem-se os cárceres para os operários que lutam por melhores condições de vida e (...) os patriotas que combatem o imperialismo norte-americano e repelem seus planos de guerra (...). (A pintura) de Portinari (...) reaviva a memória dos senhores das classes dominantes e de seus patrões americanos, dando ao povo um exemplo de heroísmo do qual se orgulham os herdeiros de Tiradentes. Os que lutam hoje pela libertação do proletariado e pela grandeza da Pátria."292

Nessa época, as relações entre Estados Unidos e URSS haviam-se deteriorado. A disputa imperialista entre as duas nações era fato consumado. Logo teria início a Guerra da Coréia. ${ }^{293} \mathrm{O}$ tema da pintura de Portinari tinha amplitude e servia muito bem para justificar tanto o combate às classes dominantes pró-americanas no Brasil como a luta por "libertação nacional", impetrada pela Coréia do Norte e incitada pela URSS contra

${ }^{291}$ s. a. "Tiradentes - um exemplo do povo que é símbolo e exemplo de lutador" In Voz Operária, São Paulo, 13 de agosto de 1949, sem página. (parênteses nossos).

292 Idem, ibidem. (parênteses nossos).

293 Após muito tempo como possessão do Japão e com a derrota desse país na Segunda Guerra, a Coréia foi dividida em dois países, um sob influência da Rússia e outro dos Estados Unidos. Em meados de 1950, a Coréia do Norte, pró-URSS, invadiu a do Sul. em defesa da libertação nacional da Coréia e reunificação do país. Em resposta ao ataque da Coréia comu nista, os Estados Unidos enviaram tropas da ONU para rechaçar a ameaça comunista e pediram que o Brasil, como país Aliado, participasse da guerra. 
os Estados Unidos. Há muita semelhança entre a denúncia feita na obra de Portinari sobre Tiradentes e a pintura de Picasso intitulada "Massacre na Coréia" de 1951. Ambas têm como tema principal a luta contra a dominação estrangeira, a vontade expressa pelas camadas populares de se libertarem para constituir uma nação soberana. A diferença concentra-se no fato de que Portinari representou a luta dos brasileiros por meio da história da vida pública de Tiradentes. O Pintor tomou o herói como exemplo para as camadas populares. Por um revés calculado, a morte de Tiradentes significa o irromper da vida e a vitória do povo. A saga e o martírio final do herói nacional representam a tomada de consciência progressiva do povo e incitam este à ação para que seu destino histórico se complete. Já, em Picasso, no centro da luta por libertação nacional está o povo, figurado como mártir da guerra.

"Massacre na Coréia" foi feito para funcionar como propaganda antiamericana. Picasso coloca frente a frente no campo de batalha dois amontoados de gente. De um lado estão mulheres grávidas, jovens e crianças, de outro, soldados norte-americanos armados com toda a parafernália da guerra. O contraste não está na cor, onde predominam os tons cinza chumbo, mas na forma. Entre a gente coreana domina a linha curva, a referência a formas orgânicas e entre os norte-americanos, linhas e formas geométricas que lembram mecanismos, homens-máquina. Os norte-americanos são despersonalizados e se encontram dentro de invólucros de metal que lembram armaduras medievais; os coreanos sem armas e nus são humanizados pela sua fragilidade. Fuzis apontados e expressões de desespero. Para tornar a cena dramática, Picasso separa os grupos e apresenta o exército invasor não somente dotado de isolamento físico diante do ambiente que o circunda, mas também distanciado psiquicamente de suas vítimas. Distância proposital: luta entre o homem e a máquina de guerra do Estado imperialista. As razões da guerra são de ordem instrumental, que dizem respeito ao poder e não ao homem. ${ }^{294}$

\footnotetext{
${ }^{294}$ A obra de Picasso causou celeuma na França e principalmente nos Estados Unidos, onde o Realismo Democrático rivalizava ainda com a arte moderna: "Quando Massacre na Coréia foi exposto no Salão de maio de 1951 (...), as questões de engajamento político, realismo social e inteligibilidade foram mais uma vez polemizadas na imprensa de esquerda. Os Modernistas, na época e desde então, atacaram a pintura, considerando-a "um fracasso estético". (...) A comunidade artística de Nova York ficou desconcertada com o "novo Guernica" de Picasso, no qual o agressor contra mulheres e crianças indefesas era a máquina de guerra americana, não a alemã. No contexto dos primeiros temores macarthistas, a visão esteriotipada de Picasso sofreu um bombardeio: ele foi caracterizado como um gênio despolitizado e extraterreno, cuja compreensível preocupação com a paz (...) havia sido explo rada por comunistas amorais e doutrinários. Depois que, no dia 16 de agosto de 1949, o congressista Dondero, de Michigan, fizera o seu discurso sobre'A arte moderna acorrentada ao comunismo' na Câmara de Deputados americana, os órgãos artísticos institucionais passaram a se empenhar muito para convencer os americanos de que (...) a arte
} 
Em 1950, Portinari e Picasso foram convidados a participar de cerimônia no II Congresso Mundial da Paz, em Varsóvia. Esse Congresso era, em sua maioria, formado por membros de partidos comunistas ligados à URSS. Ali, Portinari ganharia, por seu painel Tiradentes, medalha de ouro. Tanto Portinari como Picasso tinham compromisso ético com o PC, fizeram suas tentativas e apontaram uma via de pesquisas para a arte do pós-guerra. Uma arte de propaganda. ${ }^{295}$ Naquela época, ainda se discutia, pelos centros da cultura, qual seria o tipo de arte possível depois da guerra, da bomba de Hiroshima e dos campos de concentração de Auschwitz ${ }^{296}$. O realismo socialista vigorava na URSS stalinista, os partidários do governo Harry S. Truman criticavam a arte moderna, tachando-a de subversiva, e consideravam o realismo democrático como a verdadeira arte das Américas. A França, que era apontada como o centro irradiador da cultura mundial, até a invasão dos nazistas em 1940, encontrava-se dividida entre manifestações de arte vinculadas às experiências anacrônicas da Escola de Paris, sobretudo o cubismo, a influência moral do PCF e as missões culturais norteamericanas. De fato, no cenário mundial, tanto a arte realista mantinha ainda sua força como o abstracionismo despontava no horizonte da arte moderna.

A opção pela arte abstrata provinha em parte dos esforços dos artistas ligados à esquerda norte-americana e em parte da continuidade das pesquisas plásticas realizadas em países que sofreram influência da Bauhaus e dos resultados dos acordos culturais entre a velha república de Weimar e a URSS dos tempos de Lênin. Por um lado, os artistas norte-americanos estavam desiludidos com a fórmula da arte como arma revolucionária. Aqueles que enveredaram pela arte realista nos anos trinta, viram ou sua cooptação e sua utilização como propaganda pelo governo dos Estados Unidos, ou sua filiação ao realismo socialista. Também, dada a proximidade dos artistas de esquerda norte-americanos com o trotskismo, eles se tornaram críticos da forma política e das

moderna não era um complô comunista para solapar os valores e a democracia ocidentais. Alfred H. Barr Jr., Nelson Rockfeller e Thomas Hess (diretor da Art News) vinham se esforçando muito para identificar a arte moderna com a liberdade. De repente, lá estava Picasso, com inúmeras obras no MOMA, atrapalhando sua causa.” FRASCINA, F. “A política da representação” In WOOD, P. et alii. Modernismo em disputa - a arte desde os anos quarenta. São Paulo: Cosac \& Naify Edições, 1998, p. 141.

295 Conforme mostra Aracy Amaral, Portinari chegaria a dizer, em 1948, que: "não existia mais confronto entre "modernismo e academicismo", mas a tendência "hoje é para a arte figurativa - para o realismo. Uma arte mais legível. Uma arte que o povo possa compreender. Isso não quer dizer uma volta e nem uma arte acadêmica. Mas uma arte para o povo. E não para meia dúzia de 'viciados' em folhinha e nem para os snobs.” AMARAL, A. A. Arte para quê? - a preocupação social na arte brasileira (1930-1970). São Paulo: Studio Nobel, 2003, p. 241.

${ }^{296}$ Cf. ADORNO, T. W. Notes sur la littérature. Paris : Flammarion, 1984, p. 298 e seguintes. Nesse ensaio, Adorno discute como a arte engajada e a arte autônoma podem as sumir conotações diferentes de acordo com o contexto histórico-social em que se desenvolvem. Os exemplos são a França e a Alemanha do pós-guerra. 
manifestações de arte na União Soviética. Em todos os cantos, o realismo nas artes plásticas tornara-se arte oficial. O abstracionismo de cepa expressionista vinculava-se ao seu novo modo de pensamento: a realidade que não se deixava mais representar depois da bomba de Hiroshima, a crise do comunismo como alternativa para o mundo, a revolta do indivíduo contra os Estados totalitários. Por outro lado, começavam a surgir, em países emudecidos pela repressão nazista e pela guerra, artistas que haviam estudado na Bauhaus ou que tomaram contato com as exposições de vanguarda russa. Esses artistas, tais como Max Bill, propunham uma arte calculada, baseada em preceitos perceptivos e na continuidade da tendência construtiva da arte moderna russa.

No Brasil, a polêmica entre realismo e abstracionismo se instaurou em 1948. Diz Aracy Amaral: “(Foi nesse ano que,) o abstracionismo daria seu estremecimento de penetração (...), através de 'duas exposições capitais', como as denominou Mário Pedrosa, e que 'indicavam sobretudo aos jovens que Paris não é mais a capital propulsora das Artes no mundo como foi durante séculos': uma no Rio, de Alexander Calder, realizada não por iniciativa oficial, posto que o inventor dos 'móbiles' ainda 'não ganhara os galardões da fama nos meios internacionais nem prêmios nos mercados de arte', mas durante a permanência amiga no Rio do artista norte-americano sobre quem Mário Pedrosa escrevera (...) longo artigo publicado no Correio da Manhã, a partir de Nova Iorque, onde então residia; a segunda exposição foi em São Paulo, no MASP, de Max Bill, construtivista suíço, em retrospectiva impecavelmente realizada, e que já incluía a 'Unidade Tripartida', que obteria, em 1951, o Grande Prêmio de Escultura da I Bienal de São Paulo. Curiosamente, essas duas exposições apresentam duas tendências do abstracionismo: uma, a de Calder, com a predominância do intuitivo e o relacionamento ambiental, no Rio, que se poderia assinalar como uma característica do neoconcretismo carioca de fins dos anos 50; e a outra, a de Max Bill, fundada na matemática e no rigor desprovido de vinculações subjetivas, que governaria o concretismo em São Paulo, sob a liderança de Waldemar Cordeiro, após a I Bienal.”297

A militância nas alas trotskistas, o Manifesto de Trotski e Breton, a vivência e o contato com críticos e com o artista Alexander Calder nos Estados Unidos colaboraram para a atuação de Mário Pedrosa em sua volta ao Brasil em 1945. Sua escolha em favor da arte abstrata era resultado da necessidade sentida de repensar o significado da arte moderna no pós-guerra. A batalha entre realismo e abstracionismo começara e

\footnotetext{
297 AMARAL, A. A. Op. cit., p. 229. (parênteses nossos). O artigo de Pedrosa citado pela autora: PEDROSA, M. “Às vésperas da Bienal” In Mundo, homem, arte em crise. São Paulo: Perspectiva, 1975.
} 
"Tiradentes" foi o alvo principal de Pedrosa. Ele fez questão de ressaltar - como em outras ocasiões - o conflito existente entre o conteúdo e a forma na obra de Portinari, apontando como uma de suas causas o desprendimento ocorrido na arte moderna em relação à função ilustrativa simples. Se a pesquisa da forma empreendida pelo Pintor intentava sempre dar visibilidade ao tema, para Pedrosa não havia possibilidade de retorno às exigências exclusivas dos gêneros na pintura. Essa série de preceitos e de normas compositivas dos gêneros trazia à tona uma pretensa codificação da realidade, que projetava os aspectos essenciais de descrição da natureza humana fixa em seus diversos aspectos, seja anímico, moral ou consuetudinário. O Crítico acreditava que essa concepção de realidade fora superada e sua mutação extraordinária exigia um novo tipo de apreciador da arte, não mais preocupado em acompanhar o desenvolvimento literal de uma narrativa ou de um assunto na pintura. Nela, instaurava-se a exigência de maior atenção às qualidades envolvidas na apreciação do modo como o pintor produziu a forma, lidou com as tintas e enfim estruturou o vínculo entre as formas e as cores.

$\mathrm{O}$ contragolpe argumentativo de Mário Pedrosa foi mostrar em que medida $\mathrm{O}$ “Tiradentes" de Portinari ou a prática da pintura mural não se situavam mais como manifestações atuais da arte moderna. Para isso, o crítico situou o problema entre as dimensões do painel de Tiradentes e as dificuldades encontradas pela função ilustrativa ou descritiva na obra. Se essa função exigia o tratamento pormenorizado dos detalhes, a visão do todo não prescindia deles, e a solução plástica encontrava-se justamente na harmonia desses fatores. Contudo, as dimensões do painel produziam um antagonismo entre a exigência descritiva e a visualidade da obra na solução final. Isso porque Portinari firmou a importância do detalhe para uma maior aproximação com o acontecimento histórico e ao fazê-lo em um painel muito alongado, expôs a difícil unidade entabulada entre as partes. De fato, a falta de proporcionalidade harmônica do painel - com 3,15 de altura e 18 metros de largura - impedia tanto a composição realista satisfatória do gênero histórico como não permitia que o espectador abarcasse de uma só vez a unidade visual da obra.

A solução plástica fora conseguida pelo esforço descomunal de Portinari, que soube ordenar e por vezes harmonizar na composição as áreas de cor. Mesmo assim, tem-se a impressão de que muitas partes do painel estão desagregadas por causa da intenção de adaptar as cenas da pintura aos pormenores descritivos. Da inconveniência estrutural das dimensões para a execução do painel, Pedrosa ampliava o questionamento sobre o significado do painel e da pintura mural em relação ao seu suporte. Tratava-se 
de encontrar, para além do conflito entre o conteúdo e a forma no interior da obra, sua unidade visual com o edifício. Comenta Pedrosa: "A sua radical horizontalidade tende a delimitar, senão o gênero, os temas a que se amolda. (...) $O$ fato é que o retângulo dado a Portinari é por demais particularizado nas suas proporções para prestar-se facilmente a qualquer tema. Talvez, por isso mesmo, seja do ponto de vista estrutural mais propício à pura decoração arquitetônica do que ao gênero épico, ao drama heróico ou místico, para o qual maior campo no sentido da altura é uma vantagem: permite um acento mais pronunciado sobre o eixo vertical. ${ }^{, 298}$.

As dimensões do painel sobre saga do Herói nacional dificultavam que as cenas da composição se desenrolassem em uma seqüência satisfatória. Também foram prejudicadas a composição e a ordenação das cores em seu aspecto visual como um todo, mesmo que Portinari tivesse conseguido adequá-las de parte a parte. Além disso, a ênfase no detalhamento das figuras (senhores, damas, oficiais, soldados e escravos) e na caracterização realista do ambiente histórico (Tiradentes com o povo, a praça de sua execução, etc.) encontrava-se em oposição frontal às necessidades visuais do painel, que solicitavam menos atenção às partes do gênero histórico e mais homogeneidade nas formas e nas áreas de cor. Sem dúvida, o empreendimento plástico era compatível com a envergadura de Portinari, mas o que Pedrosa punha em dúvida era a adequação entre o gênero realista e a estrutura engendrada para a composição, bem como a relação entre o painel de Tiradentes e o moderno Colégio de Cataguazes, Minas Gerais.

$\mathrm{O}$ interesse crescente do Pintor pelos efeitos visuais aparentados à descrição fotográfica - e outras técnicas documentárias - indicava a ausência de vitalidade no painel de Tiradentes e, por conseguinte, a obra não transmitia força expressiva através da obra para o apreciador. A trama de significações na obra vinha de fora e não da intervenção criativa do Pintor. Segundo Pedrosa, a energia despendida pelo artista para alcançar o valor plástico era mais importante que o reconhecimento dos objetos. A insinuação de um gesto em sua potência, a sugestão bem feita da ação nas figuras caracterizariam o valor artístico que vai além da contingência dos fatos. Depreende-se disso que a ênfase descritiva da cena resumia-se à apresentação da matéria inanimada sem o concurso do espírito, que dava vida aos elementos figurativos da pintura. A raiz desse problema no painel de Portinari, com extensão na prática artística do realismo socialista, encontrava-se na tentativa de transposição de um momento real para a obra.

\footnotetext{
${ }^{298}$ PEDROSA, M. “O painel de Tiradentes” In Acadêmicos e modernos, (org. Otília B. F. Arantes). São
} Paulo: EDUSP, 1986, pp. 175-176. 
Esse procedimento limitava a importância da expressão própria da arte e revelava a falta de vivacidade do painel, sem a qual não seria possível despertar no espectador sentimentos condizentes com o tema e o modo como foi tratado.

Comparando Portinari à plêiade dos maiores artistas mundiais, Pedrosa não deixa de nos dar seu veredicto: "Portinari (...) nem sempre evitou a ilustração que é o exagero realista do gênero. Rembrandt e Goya foram mestres da pintura que conta uma história. Mas para tanto tiveram de criar uma forma adaptada ao assunto. Eles, porém, nunca desceram às minúcias do acabamento na forma (...). Quando se desce, entretanto, ao acabamento minucioso dos membros gotejantes de sangue e dos quartos escalpelados de Tiradentes, sobretudo o do poste no primeiro plano, que sai positivamente para fora da tela, é forçosa a queda na catalogação dos detalhes, com vista apenas no assunto. É inevitável também que a composição sofra. (...) essas minúcias descritivas, entre as quais nenhuma supera em mau gosto as poçinhas de sangue vivo de tinta tirada diretamente da casa de ferragens (...) ainda se justificam menos em face do destino da obra, que é para ser vista à distância, como todo mural. Assim, esses pormenores não têm a menor função plástica ou pictórica; o artista aqui foi simplesmente vítima do prisma literal sob que encarou o tema."299

De uma parte, tinha-se o pouco destaque dado no painel de Tiradentes ao todo plástico em favor da prevalência do tema, da minúcia narrativa e dos aspectos particulares da cena, de outra, estabelecia-se a necessidade de interpretação da pintura em seu ajuste com o desenvolvimento da arquitetura moderna. Se a horizontalidade da tela exigia que o espectador tivesse uma apreciação isolada das partes, também era verídico que a exigência de uma visão do conjunto do painel introduzisse seu vínculo com o edifício. Nesse vínculo superlativo da estrutura visual concentrava-se a dissonância entre a sensibilidade artística advinda da pintura de Portinari - referendada pelo primado do conteúdo sobre a forma - e o edifício moderno com seu destaque para as qualidades contidas nos materiais mobilizados com a forma. Em uma classificação diversa do significado corrente atribuído ao tema, Pedrosa recompunha sua importância sob a égide de duas condições, a estrutura visual e a funcional da arquitetura. Com elas, o tema deixava de ser pensado como parte indispensável e municiadora de conteúdo literário para a pintura e passava a ser elemento contribuinte do significado estabelecido pela liberdade criativa na forma.

${ }^{299}$ PEDROSA, M. Op. cit., p. 179. 
Em outras palavras, Pedrosa fazia a distinção entre o tema como vínculo extrínseco da obra com a realidade e como matéria específica da realidade plástica para a elaboração da forma. Nesse sentido, o painel de Tiradentes destoava da mensagem estética e funcional fornecida pela estrutura arquitetônica. Esta, em sua exigência de transparência, requeria do tema tratado por Portinari "uma severíssima adaptação à natureza estrutural da parede. O Colégio de Cataguazes é um edifício moderno, em que o vidro tem papel não só eminentemente funcional como decorativo. Ele devora os vãos, reduzindo ao mínimo a aparência de solidez das estruturas para valorizar a claridade e a leveza. Por ele, desmancha-se a separação dos espaços exteriores e interiores. Fica-se, por isso, em dúvida se uma parede em tal ambiente realmente suporta dramas carregados, sombrios, ou não repele a óptica ilusória das perspectivas que afundam. Não pediria ele antes um enriquecimento decorativo sóbrio para o puro regalo dos olhos? ${ }^{, 300}$

A transparência regia a arquitetura moderna e o painel de Portinari sobre Tiradentes foi definido por Pedrosa como carregado de cores. Essa relação antitética entre as duas expressões artísticas denotava o interesse de Mário Pedrosa pela arte que, através da pureza no tratamento de seus elementos, expunha seu conteúdo. Não se tratava pois de negar o conteúdo social da obra de arte, mas de entendê-lo como parte de um significado mais amplo contido na pesquisa revolucionária da forma executada pela arte moderna. Do conteúdo não resultava a transposição direta ou indireta de um tema, para que a pintura ilustrasse, mas a verificação do processo de feitura da obra, do trabalho imprescindível no material que a especifica. Com isso, Pedrosa ia além da refutação tão importante e eficaz da influência da literatura ou do discurso ideológico nas artes plásticas e propunha um outro fundamento para a inter-relação entre o conteúdo e a forma. Essa cisão com a teoria do reflexo fixo da realidade, avalizava como inequívoco o processo social material na produção da arte, em vez de concebê-la apenas como metáfora do mundo.

O destaque sobre a especificidade das artes plásticas traduzia-se no valor atribuído às suas leis próprias e à sua independência em relação a um conceito dualista aplicado na compreensão geral do fenômeno artístico. Esse conceito assentava-se na distinção entre infra-estrutura e superestrutura, entre realidade e arte, dividindo-se em duas vertentes: na primeira, ele apenas reconhecia a função da arte como transposição

${ }^{300}$ PEDROSA, M. Op. cit., pp. 176-177. 
passiva da realidade e, nesse caso, a arte era entendida como inessencial em relação ao conteúdo objetivo da própria realidade. $\mathrm{Na}$ segunda vertente, o conceito dualista continuava a efetuar a separação entre arte e realidade, porém ao reconhecer a primazia do conhecimento da realidade ou da infra-estrutura, engendrava um critério de avaliação para a produção artística. Isso tornava possível distinguir na arte, a melhor conformação do conteúdo. Tanto uma como outra posição distanciavam-se do caráter específico e ativo da arte. Assim, quando Pedrosa revelou o trabalho específico para feitura da obra como momento do processo social material da arte -, ele não deixou também de salientar a mensagem da arte independente em relação ao contexto social e político estabelecidos.

De acordo com o Crítico, a nova arte revelava seu lastro com o processo social material e diferenciava-se - de todos os outros processos - por suas características próprias. De sua especificidade advinham duas contribuições cognitivas para a formação da consciência do homem moderno. Uma, dizia respeito à compreensão da atividade artística como produto social, o que contribuiu muito para o processo de dessacralização da arte. Outra, como resultado do teor específico da arte, atuava com exclusividade no campo da estética para a mudança profunda da sensibilidade do homem. Esse direcionamento conceitual distanciava-se da compreensão da arte como metáfora simples do mundo - tal como descrita na teoria do reflexo -, visto que o processo material implicado na elaboração artística tornava objetivo o vínculo da arte com o mundo. Passava-se assim à formulação do conceito de mediação entre o produto artístico e as demais atividades sociais. Ao invés da especificidade da arte significar em suma um distanciamento ideológico da atividade social, ela se constituía como uma alternativa concreta e de impacto crítico sobre todas as práticas culturais e sociais estabelecidas.

A teoria do reflexo propunha que a realidade fosse transposta ou refletida na obra. Para isso, toda atividade artística deveria restringir-se à captura dos dados sensíveis imediatos e fundar, a partir deles, sua função prioritária de observação simples e objetiva da realidade, cujo respaldo era encontrado nos meios mais avançados da técnica descritiva ou documentária. De sua parte, Pedrosa acreditava não ser possível separar observação pura e simples e realidade ideada ${ }^{301}$, visto que o artista valia-se de toda amplitude de sua dimensão espiritual e não de um ponto de vista naturalista ou

\footnotetext{
${ }^{301}$ CF. PEDROSA, M. "Equívocos do realismo em arte” In Política das artes, (org. Otília B. F. Arantes). São Paulo: EDUSP, 1995, pp. 99-102.
} 
objetivo-mecânico para elaborar a obra. Assim também, o Crítico reexaminaria a problemática do reflexo na arte e concluiria - em ensaio publicado no Jornal do Brasil em 17-04-1957 - que ela se baseava em uma compreensão equívoca sobre o que era a realidade, "que não se define pela matéria mas pelo espírito. De modo que a realidade que expressa um artista não é a dos seres e coisas materiais; é a realidade que sente como ordem de vida, como intuição do absoluto. Vida com maiúscula, então, em que se confundem experiência, idéia, sentimento e vontade para intuí-la como um todo.”302

Essa demanda pelo todo foi o que levou Pedrosa a analisar o painel de Tiradentes em relação à arquitetura moderna. Tratava-se de uma nova via para a compreensão do fenômeno artístico. Somente assim o artista desvencilhava-se do fazer artístico mecânico, e a reivindicação de transparência ou pureza - em franca oposição à concepção da arte como forma ilustrativa de um conteúdo - simbolizava a finalidade de superar a velha separação entre espírito e matéria, conteúdo e forma na obra. Essa unidade garantia um afastamento deliberado tanto da fragmentação social como do empirismo visual, e cultivava a formação de consciência como processo libertador do homem de nossos dias. Pedrosa via, nessa restauração da importância do espírito na arte e na sociedade, a única maneira de insuflar sentido novamente à vida. Nela, a ordem se manifestaria pela revelação da insuficiência do racionalismo instrumental para o planejamento de uma nova sociedade e pela exigência da integração de todos os aspectos psíquicos e sociais na decifragem da vida.

Com o embotamento da experiência humana cada vez mais condicionada às exigências utilitaristas, a oportunidade de ampliar o sentido da razão ou da consciência humana encontrava-se na arte. Por sua hora, essa se encaminhava para uma unidade não apenas das artes particulares, visando também integrar as dimensões pública e privada dos homens. A prevalência do conteúdo sobre a forma no painel de Tiradentes indicava o interesse de Cândido Portinari em manter presente a influência que nele exerceu, desde o início de sua carreira, a arte acadêmica de conotação realista. Com isso, ele a incorporava à pesquisa da forma implementada pela arte moderna - em particular à da Escola de Paris da qual foi seguidor - de modo a aproximar sua mensagem do público,

\footnotetext{
302 PEDROSA, M. "Realismo socialista na escultura" In Obras Completas, (organização Otília B. F. Arantes; revisão e normalização Iná Camargo Costa). São Paulo, Sem data, Volume I, pp. 51-52. (cópia no MAC-USP).
} 
sem se comprometer com o combate do fazer mecânico que tomava conta tanto da prática da arte como da rotina na percepção. ${ }^{303}$

\footnotetext{
${ }^{303}$ Portinari utilizava-se da arte como arma revolucionária. Sua obra "Tiradentes" acentuava isso. Em sentido oposto, a meta principal de Pedrosa consistia em ultrapassar a objetivação empírica ou banal da experiência artística consoante à manutenção de um ponto de vista naturalista ou realista na apreciação. Esse apelo para o descondicionamento da prática artística e da percepção do público, em geral, visava interferir nas preferências fundadas de modo unívoco no costume ou no hábito, que por sua vez contribuíam para o esvaziamento da experiência estética.
} 
Capítulo 4. De Cândido Portinari à tendência construtiva: o legado de Mário Pedrosa 


\section{$\underline{\text { De Cândido Portinari à tendência construtiva }}$}

Somada ao estímulo para a formação do primeiro núcleo de artistas abstratoconcretos no Rio de Janeiro em 1948, a crítica de Mário Pedrosa ao "Tiradentes" de Portinari deve ser entendida no contexto da disputa entre realismo e abstracionismo. Tratava-se de virar a página, de uma ruptura com a tradição figurativa nas artes plásticas do Brasil, que permitiria o livre curso e o aprimoramento da arte abstrata de tendência construtiva. Essa surgia como algo mais sólido que um simples modismo e Pedrosa tentou encontrar, nas manifestações artísticas mais renovadas, alternativa de combate à utilização da arte no plano nacional e internacional. Fora e dentro do País, o realismo não produzia mais consciência nem conseguia se desgarrar das ideologias dominantes. No plano internacional, a arte realista tinha se tornado instrumento de propaganda e era defendida tanto na URSS, com o realismo socialista, quanto na Europa - como no caso francês, onde o PCF tentava aproximar os intelectuais da via realista e lutava contra as tendências de vanguarda - e, nos Estados Unidos, apoiada pelos setores conservadores que pregavam a continuidade da tradição artística das Américas. No plano nacional, a arte de ênfase temática tinha se enredado na retórica do Estado Novo e, posteriormente, no apoio à causa do $\mathrm{PCB}{ }^{304}$

Portinari representava o coroamento da grande tradição figurativa brasileira e, por isso, a crítica de Pedrosa teve tanta repercussão tanto entre os que vislumbravam um recomeço para a arte moderna como entre os que defendiam enfaticamente a continuidade do realismo figurativo. Aracy Amaral comenta a cooptação de Portinari pela ideologia do Estado Novo. Ela conclui que Portinari foi "Pintor oficial" do Governo: “(...) por suas posições políticas conhecidas, por sua preocupação com o dado

\footnotetext{
304 Entusiástico com o fim da voga realista na arte brasileira, Frederico Moraes diz: "Esta abstenção política, entretanto, teve suas razões. Um dos principais objetivos da vanguarda brasileira nos anos 50 era a afirmação da especificidade do fenômeno plástico-visual, da autonomia da forma em relação ao aspecto anedótico e/ou temático. Objetivo que se coadunava com outro, a afirmação de uma crítica de arte voltada exclusivamente para os aspectos intrínsecos da obra - forma, cor, espaço, tempo, etc. Desta maneira, um dos alvos visados pela vanguarda (talvez até de forma inconsciente) era Portinari, em cuja obra, o aspecto 'literário' ou mesmo sua formação acadêmica eram mascarados por um contraditório engajamento político. O extraordinário prestígio e sucesso de Portinari na área oficial estavam retardando o desenvolvimento da arte brasileira. Influenciada pelo muralismo mexicano e pelo expressionismo internacional, que impunham, via Portinari, uma visão deformada de nossa realidade social, a arte brasileira marcava passo. Assim, um marco decisivo no sentido de uma renovação, foi o prêmio dado a Volpi na II Bienal.” MORAIS, F. Artes plásticas - a crise da hora atual. Rio de Janeiro: Paz e Terra, 1975, p. 81 .
} 
popular, apesar de sua formação estritamente acadêmica, e por ela mesma, (Portinari) não deixa de vincular o artista à realidade imediata, por várias razões; uma delas assinala bem a maneira como assume ser um artista oficial, de acordo com a tradição do século XIX brasileiro, ao afirmar que o meio ambiente é que tem culpa pela situação do artista, (Portinari referia-se ao vínculo estreito que a arte tem com as instituições nacionais e suas políticas) posto que "Todos são obrigados a ter outras ocupações para poderem viver. Na realidade, ao artista que não vive da sua profissão nada se lhe pode exigir. Do império para cá, os governos cada vez se preocupam menos com a Arte e tudo é decorrente desse estado de coisas. ${ }^{, 305}$

Annateresa Fabris propõe uma análise de Portinari, que parte das obras com temática sobre o trabalho até chegar aos "Retirantes", a fim de refutar a posição corrente sobre a oficialidade do Pintor. Diz ela: "Embora a crítica oficialista não tenha incidido muito na temática do trabalho, é justamente nela que são encontrados os elementos para uma leitura ideológica da obra de Portinari, e não à luz do oficialismo. [...] Para tachar Portinari de 'pintor oficial' não basta constatar que pintou o trabalho para um governo populista e que o fez com uma conotação (aparentemente) positiva. Se existe um elemento positivo no tratamento plástico dado ao trabalho - o gigantismo dos trabalhadores -, isso não nos deve levar a conclusões precipitadas, pois os murais do Monumento Rodoviário e do Ministério da Educação são bem ricos em significações para serem reduzidos a uma dimensão única e, no caso, pejorativa. [...] Para analisar a temática portinariana do trabalho, faz-se necessário analisar a concepção do trabalho pelo governo Vargas: é da comparação entre essas duas realidades - a estética e a

\footnotetext{
305 AMARAL, A. A. Arte para quê? - a preocupação social na arte brasileira (1930-1970). São Paulo: Studio Nobel, 2003, p. 241. (parênteses nossos). Segundo Aracy Amaral, na seqüência dessa entrevista a Ibiapaba Martins, Portinari dizia ainda ser um erro a entrada do abstracionismo no Brasil: “Na Europa, o abstracionismo foi incorporado e superado pelos grandes artistas, entre os quais André Lhote e Braque, Lhote acha mesmo que o abstracionismo é parte muito limitada da pintura. E, além disso, vocês vejam aqui no Brasil quais são os maiores interessados no abstracionismo: justamente aqueles que preferem que o artista fique brincando com uns barbantes em vez de olhar para o mundo que o cerca. Por isso, sempre achei: já que não é o tema que conta, não é nada de mais pedir aos artistas que incorporem esse pormenor à obra de arte, porque será acrescida de alguma coisa útil. Não vejo necessidade de abstenção intransigente do tema. Todo artista que meditar um pouco sobre os acontecimentos que perturbam o mundo, chegará à conclusão de que fazendo um quadro mais 'legível' sua arte ganhará ao invés de perder; e - ganhará muito porque receberá o estímulo do povo." (E Aracy Amaral continua:) “(...) (Portinari,) defendendo sua dupla preocupação permanente, há mais de dez anos percebida por Mário Pedrosa, a plástica e a social, defende a pintura temática. (...) Estranho, contudo esse 'estímulo do povo', entidade quase abstrata e totalmente alheia à experiência artística”. Idem, ibidem, p. 242. (parênteses nossos).
} 
política - que devemos retirar a visão crítica de Portinari sem optarmos, a priori, pelo oficialismo ou não-oficialismo de sua linguagem. ${ }^{\text {”306 }}$

Fabris descreve as principais características ideológicas do Estado Novo: "[Todos os partidos e os movimentos de reivindicação do operariado foram reprimidos na ditadura getulista. Inicia-se o processo de obscurecimento da consciência social da classe operária,] na medida em que o Estado assurge como instância capaz de atender a suas aspirações. Nesse quadro de referências, é de relevância o papel do pacto interclassista, que mascara o caráter conflitivo das relações de classe com a criação da ficção povo ou Nação, regida por (supostos) interesses comuns e solidários. [...] Da combinação Estado-partido-sindicato surge a figura do chefe do governo como benfeitor de todas as classes, identificados com a Nação. Cabe ao benfeitor instaurar a paz social, que permita salvaguardar a ordem. Uma ordem unidimensional por ser apenas burguesa. [...] O Estado surge, portanto, como representante de todas as classes e grupos sociais, vistos como povo, isto é, como uma coletividade regida por interesses e ideais harmônicos. [...] Ao outorgar aquelas que [Otávio] Ianni define 'condições institucionais mínimas ao exercício da cidadania' (sindicalização, leis trabalhistas, escola primária gratuita, entre outros), o Estado estabelece as condições e os limites da participação política do proletariado urbano, quer nos problemas de classe, quer na política nacional.,307

A mítica construída pelo Estado Novo concentrava-se na exaltação das idéias de Nação e de Getúlio Vargas como seu líder. Se os valores nacionais são postos em primeira plana, o que garante a harmonia entre as classes é o líder do povo, o "Pai dos Pobres”. A imagem de Vargas passa a ser difundida como a do benfeitor que harmoniza a Nação. Para isso e para garantir que não houvesse opiniões contrárias nem liberdade de expressão, criourse o DIP (Departamento de Imprens a e Propaganda). Edgard Carone diz: "No passado, o fenômeno mítico tem caráter e interesse particular, bem diferente do que apresenta com o Estado Novo. A falta de tradição de classe e a incapacidade criadora e pragmática das classes dirigentes tornam prescindível a necessidade de criar valores e basear sua ação sobre eles, pois as oligarquias mandam e são obedecidas. (...)

\footnotetext{
${ }^{306}$ FABRIS, A. Portinari, pintor social. São Paulo: Perspectiva, 1990, p. 118.

307 Idem, ibidem, p. 121. (colchetes nossos). Continua Fabris: "Os principais instrumentos do pacto populista são as reformas e o bem-estar social, a harmonia interclassista, o Povo, a Nação. Subjacente a tudo isso, a doutrina da paz social, que na realidade, nada mais representa do que a idéia da harmonia entre o capital e o trabalho, indispensável ao desenvolvimento do modelo industrial. As contradições de classe são minimizadas (...) em nome do nacionalismo, da industrialização, da reforma agrária.” Idem, ibidem, p. 122.
} 
Durante o estado Novo o fenômeno é de caráter mais complexo e pela primeira vez se manifesta contemporaneamente aos políticos, num momento em que se conjugam três fatores básicos: a movimentação de massa popular, a confusão de valores das classes dirigentes e a ação do Estado como forma de propaganda e pressão. (...) A personificação do mito é um dos traços que marcam o fenômeno. (...) Mito e comemoração se conjugam. (...) Sem oposição, sem ninguém para contestar-lhe a propaganda e a verdade, o governo usa de todos os meios para se expressar e para impor a sua imagem.",308

Supõe-se que, se o trabalho assumiu posição-chave na propaganda governamental, isso permitiria aproximar a temática das obras de Portinari, tais como "Café", os murais do MEC, entre outras, da retórica do Estado Novo. Todavia, Fabris mostra que Portinari apresenta, com uma outra conotação, o trabalhador brasileiro e sua posição no sistema produtivo: "Mesmo se partirmos desse quadro de referências, poderá parecer difícil, à primeira vista, a dissolução da equação Portinari = Pintor oficial. É justamente nesse quadro, no entanto, que está a chave para uma outra leitura do artista de Brodósqui, pois a temática trabalho nada significa por si só, dissociada do modo pelo qual é tratada. E o tratamento que Portinari dá ao tema desmente a visão oficialista. (...) A série dos ciclos econômicos não só não é obra do getulismo, quer ideológica, quer esteticamente, como evidencia a (...) liberdade do artista para com o próprio ministro Capanema, o comissário direto, que não consegue impor a Portinari a própria visão histórica da economia brasileira. (...) Se o tema é o trabalho - o denominador comum do populismo -, através dele, Portinari denuncia a falsa eqüidade do pacto populista. Nos discursos de Getúlio Vargas, todas as categorias sociais são consideradas igualmente trabalhadoras. Nos painéis de Portinari (a autora faz referência aos murais do Ministério da Educação), aparece uma única categoria de trabalhadores: a massa marginal, o proletário. Rompe-se, portanto, o pacto capital/trabalho, na medida em que o negro é alçado a símbolo do trabalhador braçal brasileiro."309

\footnotetext{
${ }^{308}$ CARONE, E. O Estado Novo (1937-1945). Rio de Janeiro, São Paulo: Difel, 1976, pp. 166-170.

${ }^{309}$ FABRIS, A. Op. cit., p. 125. (parênteses nossos). A conclusão de Fabris é que Portinari não se apega à referência histórica oficial e falseada, mas apresenta seu ponto de vista sobre esses acontecimentos: "Se tentarmo s aplicar à temática social de Portinari a teoria marxista da alienação, veremos que a escolha racial efetuada pelo artista não se reveste apenas de um significado histórico. Isso torna-se patente se lembrarmos o negro do Descobrimento da Fundação Hispânica de Washington, Portinari "atenta" contra a verdade histórica, realçando, desde o início da colonização, o papel do braço escravo e afastando-se da visão oficial do acontecimento, no conjunto do Ministério da Educação, não é só a história que guia a visão do artista. (...) o negro desenvolve vários papéis que explicitam a visão do artista: - é uma afirmação racial, - é um reconhecimento de seu papel histórico, - é símbolo do proletário." Idem, ibidem, pp. 125-126.
} 
Nos "Retirantes", Portinari concentra-se na denúncia da vida que levam as populações de camponeses esquecidas pelo poder público. Para Fabris, a temática sobre o trabalho foi substituída pela denúncia da realidade legada pelo getulismo: "O ‘otimismo' que caracteriza a temática do trabalho desaparece na década de 40, quando Portinari pinta os retirantes. [...] O rigor plástico é substituído pela explosão apaixonada de 1944. Sob o impacto da guerra e de Guernica, Portinari desarticula, escava suas figuras até reduzi-las à essencialidade expressiva. Se o social parece estar ausente dos primeiros retirantes, é, ao contrário, a tônica desse segundo momento, que denuncia frontalmente o pacto populista. [...] O ser alienado perfila-se claramente: passividade, fraqueza, morte. Esquecido pelas leis sociais, o retirante é repelido pela natureza. De onde deveria brotar vida, brota morte. A terra que trabalhou para o outro serve-lhe de sepultura. O ciclo da alienação fecha-se: o retirante é a outra face do trabalhador, é a outra face do progresso social, é a verdadeira face da fachada populista. Na denúncia emotiva, Portinari não lança nem mesmo mão do elemento racial: o retirante é indiferentemente negro ou branco (a incidência nessa série recai no branco). A marginalização deixa de ter cor para converter-se numa realidade mais ampla, que, em certos momentos, assume características universais." 310

A questão sobre se Portinari foi ou não "pintor oficial" merece ser posta em termos mais amplos. Embora a designação "oficial” restrinja-se à cooptação de Portinari pela política cultural e à sua assimilação da ideologia do Estado Novo, é preciso analisar a significação e o impacto de suas obras, com temática sobre o trabalho e sobre a história do Brasil, não apenas no plano nacional, mas também no internacional. Aracy Amaral compreende bem a assimilação que Portinari faz da ideologia estadonovista. A versão do pintor sobre o papel do Estado no amparo dos artistas parece estar baseada nos laços inculcados pela cultura paternalista brasileira, acentuados pelo populismo, no qual o papel do Estado deixa de ser instrumento de cidadania para ser benfeitor das classes menos favorecidas. O direito torna-se uma exceção. Porém, é um equívoco dizer que Portinari transpôs concordância e assentimento com a ideologia e com a política do Estado Novo para os seus murais, em particular os de temática histórica: aqueles sobre os diversos períodos da história econômica do Brasil, feitos para o MEC, e aqueles sobre a descoberta e colonização da América para a Biblioteca de Washington.

\footnotetext{
${ }^{310}$ FABRIS, A. Op. cit., pp. 134-135.
} 
A resposta de Annateresa Fabris à asserção de Aracy Amaral é muito mais convincente. Pela análise acurada das obras supracitadas e das que têm como temática o trabalho, Fabris decifrou a solução plástica encontrada por Portinari para representar a realidade brasileira e a tomada de posição dele em favor, e mais ainda, ao lado, da luta do proletário e do camponês. Tanto a figura do negro como a dos retirantes são provas indubitáveis de que as obras do Pintor não eram resultado da reprodução automática do discurso populista, não tratavam do povo como entidade abstrata, mas traziam para a mensagem artística o ponto de vista dos explorados. Se Aracy Amaral concentrou-se nas declarações do artista para interpretar seu posicionamento político-ideológico e o produto de seu trabalho, Fabris resolveu o dilema sobre a oficialidade ou não do artista por meio do estudo da relação entre as obras e o momento histórico, dando maior ênfase à elucidação da temática das obras. Esse foi seu mérito. Ainda que Fabris considere que a mensagem artística de Portinari, cuja essência era ao mesmo tempo estética e política, estava em franca contradição com o populismo do Estado Novo, a autora não levou em conta que muito da oficialidade do Pintor brasileiro dependeu do uso político que se fez de suas obras.

Dois aspectos se conjugam na confirmação da oficialidade de Portinari: o estético e o político. Tanto um como outro eram respostas aos impasses do momento histórico vivido. No campo estético foi influente, durante os anos trinta e o início dos anos quarenta, o realismo. Sua expressão moderna se adequava sem precedentes muito recentes às obras de grande dimensão, servia muito bem para eventos públicos e atuava com eficácia sobre as massas. Por causa da dinâmica social em que o realismo se inseria, sua mensagem não se balizava na acuidade da reflexão demorada e fina do espectador, mas deveria ser clara e direta. Todos esses elementos estéticos reforçaram o vínculo que o realismo estabeleceu com a dimensão política da sociedade. No campo político, o realismo foi o ápice da transformação da arte em suporte da política. Se, como foi visto, o realismo estivera em seus anos inaugurais ligado aos movimentos políticos revolucionários, com o passar do tempo ele se tornou instrumento governamental. A concomitância da escolha estética do realismo por artistas de várias partes do mundo, e não somente no Brasil, seguia de perto as transformações que ocorriam nas sociedades como um todo. Ao final desse processo, a mutação sofrida na capacidade combativa e transformadora do realismo foi contestada por uns artistas e por outros não. 
As obras de Portinari para o estande brasileiro na New York World's Fair, a exposição itinerante no Riverside Museum, que percorreu vários Estados norteamericanos e os Murais de Washington fizeram parte de um acordo diplomático entre Brasil e Estados Unidos. Como artista plástico, Portinari foi representante de seu País. Sua escolha como pintor oficial deveu-se muito mais ao interesse que sua obra despertou no meio artístico e político norte-americano do que aos esforços do governo brasileiro. Portinari correu até mesmo o risco de não ser escolhido como pintor oficial justamente pela força de suas obras. Contudo, para os críticos e políticos norteamericanos os traços expressionistas nas obras do Pintor não causavam tanto temor quanto o mural de Diego Rivera retratando Lênin e Marx junto aos trabalhadores da indústria Ford. Embora se diga, com justiça, que Portinari alcançou fama e sucesso em terras estrangeiras devido ao seu próprio mérito, não se pode esquecer que o interesse por sua arte adveio da grande semelhança existente entre o pintor brasileiro e muitos artistas realistas norte-americanos. A política cultural norte-americana era evidente: havia necessidade de afirmação dos valores estéticos independentes dos Estados Unidos e de distanciamento da influência cultural exercida pela Europa, e Portinari veio ratificar as raízes comuns da arte nas Américas.

A partir da fase artística que insistiu na temática dos retirantes até a execução do painel histórico para o Colégio Cataguazes, a oficialidade de Portinari deve ser entendida não mais em termos de sua cooptação pelo Estado Novo, que se esboroava, e pela missão cultural norte-americana, mas a serviço do partido comunista. A execução da série sobre a vida dos retirantes coincidiu com o breve período de expansão da influência e conquista de espaço do Partido Comunista do Brasil na política nacional. Foi nesse momento que se deu a adesão ética de Portinari à causa comunista. Devido a sua notoriedade nacional e internacional, o Pintor tornou-se benquisto pelos membros do PCB. Eles se interessavam menos por sua arte que pela influência que seu nome tinha conquistado internacionalmente e na sociedade brasileira, capaz de arrebanhar filiações e votos. Esse era um trunfo do qual não se podia abrir mão. Já a obra de Portinari sobre Tiradentes faz parte do período em que se deu o recuo da ação dos comunistas no Brasil. Com o fim do Estado Novo, iniciou-se a orientação da política interna e externa, pró-Estados Unidos. O conflito entre a URSS e os Estados Unidos se intensificava nos alvores da guerra fria, e o governo direitista de Eurico Gaspar Dutra colaborou com a política norte-americana de erradicação da ameaça comunista nas Américas. Em conseqüência desses acontecimentos, o PCB seria jogado na ilegalidade e 
sistematicamente combatido, ao passo que Portinari afastar-se-ia gradualmente da política.

Não obstante a insistente campanha anticomunista do governo Dutra, os militantes do PCB continuaram a exercer influência na política por causa da força eleitoral que o partido mantinha. Também nas artes, em várias ocasiões, os intelectuais, críticos de arte e artistas, ligados ao PCB, se pronunciaram em favor de uma arte realista e humanizadora, baseada pois na figura. A disputa dos partidários do realismo com os da abstração ganhava vulto nos jornais e o advento da fundação dos museus de arte moderna, no Rio de Janeiro e em São Paulo, e da Bienal de São Paulo, entre os anos de 1948 e 1951, marcou o ponto alto da contenda. De um lado os que defendiam a continuidade da tradição da arte moderna brasileira (Portinari, Di Cavalcanti e outros) e, de outro, os que defendiam a voga internacional, o abstracionismo. Críticos militantes do PCB lutaram em favor da predominância do realismo nas novas instituições de arte do País, porém todas elas estavam preocupadas em apresentar as tendências artísticas da época e o abstracionismo ganhou ainda mais visibilidade. Ao constatarem que a batalha pela influência sobre as instituições de arte era vã, a cúpula do PCB determinou que seus artistas boicotassem a Primeira Bienal em 1951. ${ }^{311}$

Essa tomada de posição do PCB tinha sua origem na evolução do cenário nacional e internacional do pós-guerra. Os museus de arte moderna e a Bienal de São Paulo eram instituições perfilhadas ao circuito internacional das artes que promovia, naquele momento, o abstracionismo. Este movimento ganhara força nas principais capitais do mundo devido à retomada de contato internacional com a produção européia - principalmente o concretismo suíço - e também à recente prevalência não só mais econômica e política, mas também cultural dos Estados Unidos. A Fortaleza da Liberdade, antes restrita ao Continente Americano, expandia-se para o mundo e, por conseguinte, também sua arte. Serge Guilbaut comenta as primeiras movimentações do crítico Clement Greenberg para fazer de Nova York novo centro irradiador da cultura mundial: “A chave do pensamento de Greenberg é a palavra 'independência', pois foi da autonomia que o destino da vanguarda dependeu. Independência significava independência de Paris. Nesses tempos agitados, ela era crucial - a necessidade foi talvez ainda mais imperativa do que durante a guerra - para criar uma única forma de

\footnotetext{
${ }^{311}$ Para um estudo mais aprofundado sobre a polêmica entre realismo e abstracionismo ver: AMARAL, A. A. "Realismo versus abstracionismo e o confronto com a Bienal" In Arte para quê? - a preocupação social na arte brasileira (1930-1970). São Paulo: Studio Nobel, 2003, pp. 229-271.
} 
arte, uma arte que pudesse ser forte, internacional e capaz de efetivamente combater o totalitarismo, que vinha do leste. (...) Pela primeira vez na história da arte Americana, um importante crítico mostrou ser ele próprio suficientemente agressivo, confiante e devotado à arte Americana para abertamente exigir que a arte de Nova York e Jackson Pollock tivessem seu lugar no cenário internacional da arte.”312

Como outros críticos de arte e escritores conterrâneos, Greenberg reconheceu na arte abstrata, feita nos Estados Unidos, a forma acabada e moderna que faltava ao realismo democrático e que seria, acima de tudo, capaz de dialogar com o legado da vanguarda artística européia. Esse diálogo consistia na tentativa de apresentar o Expressionismo Abstrato como modelo estético atualizado e suscetível de ser seguido. Apoiado nas conclusões de Stephen Spender e de Greenberg, Guilbaut aponta o turn point da política cultural norte-americana para o mundo: "A ausência da pintura da lista de armas no arsenal cultural lembra-nos que até esse momento os Estados Unidos careciam da mais prestigiosa dessas armas, a pintura a óleo. Essa arma, que a vanguarda trabalhara para forjar desde 1943 e que Greenberg anunciou em seu artigo ('O declínio do cubismo') de 1948, estava agora à mão. Seu artigo expôs claramente o que a maioria dos intelectuais queria ouvir, isto é, que a América estava finalmente pronta para pôr em evidência sua própria 'alta cultura'. Em outras palavras, a América estava agora a ponto de fazer a transição de nação colonizada para colonizadora. (...) A transição se deu em dois estágios: A arte Americana deslocou-se primeiro do nacionalismo para o internacionalismo e, depois, do internacionalismo para o universalismo." ${ }^{313}$

Nos Estados Unidos, o realismo declinou e o abstracionismo tornou-se movimento artístico internacional. Não só a crítica de Greenberg, mas também a ação de personalidades ligadas ao MoMA (Museu de Arte Moderna), Alfred Barr Jr. e

\footnotetext{
${ }^{312}$ GUILBAUT, S. How New York stole the idea of the modern art - abstract expressionism, freedom, and the cold war. Chicago: The University of Chicago Press, 1985, p. 168 e p. 172.

${ }^{313}$ Idem, ibidem, p. 174. Continua Guilbaut: "O primeiro item importante na agenda era livrar-se da idéia de arte nacional, que estava associada com arte provinciana e com a arte política e figurativa dos anos trinta. Este tipo de arte não mais correspondia à realidade, muito menos às necessidades da Guerra Fria. (...) Seguindo Pollock, Motherwell declarou em 1946 que 'arte não é nacional, que ser um artista meramente americano ou francês é não ser nada: falhar em superar o ambiente inicial é não alcançar nunca o humano'. Esta era então a direção intelectual em que a idéia de escola nacional de pintura - era rejeitada em favor de um humanismo universalista. (...) Jovens artistas americanos impulsionados pela heróica imagem da América na guerra contra o fascismo e incentivados pelo boom econômico e pela presença de artistas europeus nos Estados Unidos podiam pressentir finalmente um lugar para sua arte na cena internacional e um modelo de pintura igual àquele de Paris. Eles necessitavam de uma única imagem e de sangue novo para que pudessem se identificar com os soldados que embarcaram para a Europa a fim de defender a civilização contra a barbárie. Eles eram soldados estéticos que permaneceram em casa com o intuito de lutar pela mesma causa na frente cultural." (E Guilbaut conclui:) "A situação era de qualquer modo paradoxal. Com o intuito de ser internacional (...) os jovens pintores foram obrigados a enfatizar o caráter especificamente americano de seus trabalhos." Idem, ibidem, p. 175.
} 
Nelson Rockefeller, foram decisivas na promoção e vitória final da arte moderna norteamericana. Guilbaut diz: "Sobre pressão da direita, depois do manifesto antimoderno do Instituto de Arte Contemporânea de Boston em 1948, o Museu de Arte Moderna e o Museu Whitney de Arte Americana se movimentaram para salvar a mais avançada forma de arte moderna, tornando então visível o que poderia ser chamado de Expressionismo Abstrato. Entre 1948 e 1951, graças aos escritos de Clement Greenberg e ao envolvimento ativista das maiores instituições, a arte moderna foi protegida, reacondicionada e apresentada como o mais importante movimento para a nova América emergente do pós-guerra. Este foi evidentemente um novíssimo fenômeno para os Estados Unidos. Com os incidentes em torno do episódio ICA, é claro que Clement Greenberg, Robert Motherwell, Alfred Barr e Nelson Rockefeller, para mencionar apenas alguns com certa inclinação ideológica (que nós podemos chamar de um novo modernismo liberal separado do enfraquecido modernismo acadêmico muito mais procurado naquele tempo), estavam cientes da necessidade de promover uma arte baseada no individualismo, na liberdade de expressão e em oposição às produções socialistas ideologicamente limitadas."

A batalha vencida pelos defensores da arte moderna contra o pensamento conservador antimoderno não garantiu posição confortável para muitos artistas abstratos norte-americanos. Se a arte dos Estados Unidos tinha ganhado destaque no cenário internacional, ela também foi usada na reafirmação emblemática dos valores nacionais da maior sociedade capitalista do Ocidente. Guilbaut pondera sobre o surgimento de um novo condicionamento político do campo estético: “A arte moderna, a fim de ser admissível nos Estados Unidos e por razões estratégicas, tinha de perder sua superioridade negativa, tradicionalmente oposicionista, e ser até certo grau diminuída de modo a ingressar na arena internacional como uma alternativa positiva na Europa à cultura comunista. Era o preço que a arte moderna tinha de pagar. (...) Nesse período da Guerra Fria, onde a guerra foi com freqüência mais simbólica do que real, exceto quando irrompeu na periferia dos dois maiores blocos (Estados Unidos e URSS), como na Coréia, a ideologia do individualismo foi a arma por excelência nos Estados Unidos e dominou toda a esfera do social e da vida artística. O individualismo funcionava como

\footnotetext{
${ }^{314}$ GUILBAUT, S. "Postwar painting games" In Reconstructing modernism: art in New York, Paris and Montreal, 1954-1964. (editado por S. Guilbaut). Massachusetts: MIT, 1990, p. 34.
} 
o contrário da arregimentação soviética e também como o contrário das tradições artísticas da década de 1930”. 315

O sucesso da arte norte-americana na Bienal de Veneza e na mostra de Berlim, que servira de propaganda anti-soviética em 1951, foi resultado da apresentação eficaz de uma alternativa para o realismo socialista. ${ }^{316}$ Por ser uma arte avessa à mensagem política, o que se chama de Expressionismo Abstrato transformou-se em arma política do governo dos Estados Unidos. Como diria Guilbaut, “em 1951, a arte só poderia ser politizada se ela fosse apolítica". ${ }^{317}$ A explicação das origens dessa nova política cultural dos Estados Unidos para o mundo encontra-se no período imediato do pósguerra. Contra a suspeita alardeada de expansão do comunismo, o governo de Harry S. Truman desenvolveu o Plano Marshall para reabilitar o capitalismo na Europa e apostou que isso convenceria a população a adotar o modelo de vida norte-americano. No entanto, o antiamericanismo crescia entre os europeus: "Em 1946 e 1947 alguns membros do Congresso viajaram para a Europa e voltaram muito surpresos com sua recepção e com as críticas que os Estados Unidos receberam além-mar. Em reação ao que os observadores americanos consideraram ser os resultados de uma astuta campanha de propaganda comunista, o Senado aprovou o Ato Smith-Mundt em janeiro de 1948, reorganizando e expandindo o Programa de Informação e o Programa Cultural.",318

\footnotetext{
315 Idem, ibidem, pp. 36-37.

${ }^{316}$ Eric Hobsbawm avalia: “A peculiaridade da Guerra Fria era a de que, em termos objetivos, não existia perigo iminente de guerra mundial. Mais que isso: apesar da retórica apocalíptica de ambos os lados, mas sobretudo do lado americano, os governos das duas superpotências aceitaram a distribuição global de forças no fim da Segunda Guerra Mundial, que equivaleria a um equilíbrio de poder desigual mas não contestado em sua essência. A URSS controlava uma parte do globo, ou sobre ela exercia influência - a zona ocupada pelo Exército Vermelho e/ou outras Forças armadas comunistas no término da guerra - e não tentava ampliá-la pelo uso de força militar. Os Estados Unidos exerciam controle e predominância sobre o resto do mundo capitalista, além do hemisfério norte e oceanos, assumindo o que restava da velha hegemonia imperial das antigas potências coloniais. Em troca, não intervinha na zona aceita de hegemonia soviética. HOBSBAWM, E. Era dos extremos: o breve século XX (1914-1991). São Paulo: Companhia das Letras, 1995, p. 224. Continua Hobsbawm: "Pois hoje é evidente, e era razoavelmente provável mesmo em 1945-7, que a URSS não era expansionista - e menos ainda agressiva - nem contava com qualquer extensão maior do avanço comunista além do que se supõe houvesse sido combinado nas conferências de cúpula de 1943-5. Na verdade, nas áreas em que Moscou controlava seus regimes clientes e movimentos comunistas, estes se achavam estes se achavam especificamente comprometidos a não erguer Estados segundo o modelo da URSS (...)." Idem, ibidem, p. 229. E o autor conclui: "Muito mais óbvias foram as consequiências políticas da Guerra Fria. (...) Os Estados Unidos planejaram intervir militarmente se os comunistas vencessem as eleições de 1948 na Itália. A URSS fez o mesmo eliminando os não-comunistas de suas 'democracias populares' multipartidárias, daí em diante reclassificadas como 'ditaduras do proletariado'.” Idem, ibidem, p. 235.

317 Cf. GUILBAUT, S How New York stole the idea of the modern art - abstract expressionism, freedom, and the cold war. Chicago: The University of Chicago Press, 1985, p. 190.

318 Idem, ibidem, p. 192.
} 
Continua Guilbaut: "O ato prescreveu atenção para o problema de apresentar uma imagem clara e acurada dos Estados Unidos: 'Se outras pessoas nos entendessem, elas poderiam gostar de nós, e se elas gostassem de nós, poderiam fazer o que queremos que elas façam.' (...) Encorajados por Truman, que lançou sua 'Campanha da Verdade' em abril de 1950, doze senadores, em março, propuseram uma resolução chamada de ‘um plano Marshall, no campo das idéias, para todo o mundo'. O ano de 1950 assistiu à intensificação da Guerra Fria depois da fabricação da primeira bomba atômica soviética, da queda dos nacionalistas chineses e da crescente pressão doméstica contra o partido comunista. A guerra ideológica e de propaganda aqueceutse, e a fusão das duas agências prévias, que estavam separadas, responsáveis pelas atividades culturais e informação, comprova a importância atribuída à aquisição de maior efetividade nesta área. Em 1949, a propaganda começara a influenciar todos os aspectos da vida social e a se infiltrar até nas comunidades locais. (....) Melhorar a imagem cultural dos Estados Unidos foi identificado em 1948 como a meta mais importante para a propaganda americana. Mas que tipo de imagem era apropriada? Esse era o principal problema na agenda cultural (...). A arte de vanguarda poderia ser chamada americana; ela era cultivada e independente, até o momento ligada à tradição modernista. Ainda mais, ela poderia ser usada como um símbolo da ideologia da liberdade que era dominante na administração e entre os novos liberais. O triunfo doméstico da vanguarda era importante porque ela pavimentava o caminho para a conquista das elites européias." 319

As disputas entre os Estados Unidos e a URSS se intensificaram e ganharam dimensão mundial. Por isso, a propaganda - inclusive a cultural - tornou-se arma fundamental na luta econômica, política e ideológica entre as duas potências. Não somente a Europa Ocidental firmava posição sob influência estadunidense, mas também o Brasil. Nas artes brasileiras, a disputa entre realismo e abstracionismo - no ano da Primeira Bienal - refletiria também o clima da Guerra Fria. Um dos críticos de arte brasileiros que defendeu a doutrina cultural soviética do realismo socialista foi Fernando Pedreira. Seu posicionamento era de condenação da arte abstrata como formalismo vazio e como resultado da influência da política cultural dos Estados Unidos. Aracy Amaral comenta: "Este é, em síntese, o espírito do texto 'A Bienal -

\footnotetext{
319 GUILBAUT, S. Op. cit., pp. 192-193. A tese de Serge Guilbaut é que o Expressionismo Abstrato foi uma reação contra a utilização propagandista que se fazia do Realismo Democrático no governo populista de Roosevelt e que se fazia do realismo nos regimes totalitários tal como o soviético. Para Guilbaut, essa luta pela liberdade da arte frente ao uso governamental não produziu, entretanto, uma mensagem anticapitalista satisfatória.
} 
impostura cosmopolita' de (...) Pedreira (publicado na revista Fundamentos em agosto de 1951) que rechaça a 'generosidade' e o 'espírito empreendedor de Matarazzo Sobrinho, da forma como a imprensa trombeteia suas realizações, colocando a Bienal mais como uma resposta do empresariado, tentando induzir o meio artístico a se alinhar com as novas tendências da arte mundial, ao invés de se remoer com inquietações que poderiam resultar em crises desestabilizadoras de um sistema que a classe dominante deseja que permaneça.", 320

Para Pedreira, o formalismo da arte moderna se traduzia em mensagem imperialista e contribuía para alienação do povo: “Assim como fizeram nos países mais adiantados, também entre nós as classes dominantes (...) estão montando a sua máquina de corrupção e propaganda, para controlar e orientar o desenvolvimento das artes plásticas. Este verdadeiro trust chefiado por Nelson Rockefeller e que inclui, notadamente, como vimos, o Museu de Arte Moderna de Nova Iorque e o British Council (além do próprio Museu de arte Moderna de São Paulo ligado ao primeiro por um convênio) cuida agora de reforçar as suas bases no Brasil, de aumentar sua influência em nossos meios artísticos.' Fazendo 'da Bienal uma apoteose do modernismo decadente' Matarazzo Sobrinho não se limita a 'afundar a arte no pântano do formalismo moderno'. Na verdade, 'há mais de meio século que as classes dominantes perceberam o grande serviço que lhes poderiam prestar as tendências ditas modernas, tendências que negam o valor social da arte, sua função educadora e progressista, transformando-a num jogo formal para a delícia dos iniciados'. Esse seria o objetivo dos 'Srs. Rockefeller, Matarazzo, Chateaubriand, Jafet e demais mecenas do mesmo tipo.' (E conclui Pedreira:) 'Nunca se tinha visto, entre nós, manobra tão evidente para colaborar, sob o domínio dos tubarões da finança, a produção artística nacional. Nunca fora mais claro o esforço do imperialismo, através dos seus agentes (o mecenas Rockefeller à frente) para firmar posições e ganhar influência entre os intelectuais brasileiros'., 321

\footnotetext{
${ }^{320}$ AMARAL, A. A. Arte para quê? - a preocupação social na arte brasileira (1930-1970). São Paulo: Studio Nobel, 2003, p. 248.

${ }^{321}$ Idem, ibidem, pp. 249-250. (parênteses nossos). Aracy Amaral comenta: 'Na verdade, o que toda a série de artigos de Fernando Pedreira traz à tona é, em síntese, o que veríamos ser feito em relação a todo o mundo ocidental e, em particular, em relação à América Latina, na exportação pelos agentes culturais do Departamento de Estado - sobretudo o Museu de Arte Moderna de Nova Iorque - da corrente norteamericana do expressionismo abstrato, conforme registrou em Art Forum a crítica Eva Cockcroft, em artigo que aborda o problema da exportação do "modelo democrático" da arte norte-americana durante a guerra fria." Idem, ibidem, p. 250.
} 
$\mathrm{O}$ alvo do texto de Pedreira eram os capitalistas patrocinadores da arte moderna, que tentavam desvirtuar a função social da arte e cooptavam a elite intelectual brasileira, mas também Mário Pedrosa, pois sabidamente ele era o mais antigo defensor do abstracionismo no Brasil. Aracy Amaral relata: "Conforme se vê, o debate sobre realismo versus abstracionismo cederia lugar, por ocasião da abertura da Bienal, à denúncia que questiona sua realização em nosso País. [...] Grande parte desse artigo se destina, no entanto, à condenação de Mário Pedrosa que, [...] [diz Pedreira:] 'pretende provar as ligações entre a arte abstrata e a revolução soviética. Citando Kandinsky, Rodchenko e Malevitch, Mário Pedrosa faz funcionar o desmoralizado realejo trotskista para acusar os 'stalinistas', que traem a um tempo a revolução de Lênin e a arte revolucionária... $\mathrm{Na}$ verdade, esta arte que o crítico Pedrosa ainda chama de revolucionária incluiu, por algum tempo, muita gente boa. Mas logo ela revelou seu caráter falso e estéril, sua absoluta falta de conteúdo. O que se exige agora é uma arte que, talvez (para desgosto dos que se preocupam com estas coisas) não tenha relação com a obra de Rodchenko e de outros artistas do tempo em que brilhavam as flamas de outubro, como diz Mário Pedrosa.' [...] O que se desejaria, segundo Pedreira, seria, isso sim: 'Uma arte mais humana e generosa, voltada para os problemas do homem brasileiro, uma arte que ajude o povo a libertar-se da opressão e da exploração e contribua para o florescimento de uma cultura realmente brasileira. Eis porque combatemos o abstracionismo cosmopolita que nega o valor social e humano da arte'.,322.

Em artigo para a Tribuna da Imprensa, publicado no dia 03-11-1951, Pedrosa apresentava as tendências atuais da arte moderna e respondia às acusações de Pedreira de que ela era um formalismo vazio. Longe de ser um divertimento para as classes abastadas ou um campo de pesquisas somente para iniciados, a nova arte tinha ligações com o mundo do trabalho e, por conseguinte, com a base sólida da sociedade moderna. À semelhança das experiências construtivistas russas, o ressurgimento do abstracionismo, e principalmente da arte concreta, era expressão da era "neotécnica"

\footnotetext{
${ }^{322}$ AMARAL, A. A. Op. cit., p. 251. (colchetes nossos). Aí também, Aracy Amaral discute a posição de Pedrosa: "(Ele) refuta, contudo, com sua posição aberta ao longo dos anos, as idéias de Pedreira, considerando 'reacionária' a maneira como era colocado o problema da arte moderna. 'Porque havia na arte dita moderna algo que era revolucionário, que se precisava desenvolver. Daí porque tive realmente um interesse muito grande por uma arte que fosse importante no fazer, que influenciasse a vida social da época. Quis que fosse criativa nesse sentido. Quando eu falava de arte moderna eu me referia a uma arte que tivesse influência sobre a vida social da época. Eu achava que com uma arte mais desinteressada você mudava a sociedade. Essa arte iria ter uma importância na vida social. Não me interessou nunca a arte puramente desinteressada, que não fosse social.’” Idem, ibidem, p. 251. (parênteses nossos).
} 
que se inaugurava. Pedrosa diz: "Qualquer opinião que se faça sobre as pesquisas da arte moderna, nas suas expressões mais ousadas - e nos referimos especialmente aos adeptos do "abstracionismo" ou da arte dita concreta -, uma coisa precisa ser assinalada: esses artistas não propõem, antes de tudo, uma visão do mundo que quer ser atualíssima. E que (...) se anteciparia aos nossos hábitos sentimentais e mentais de hoje, numa projeção do futuro. (...) Com efeito, os pesquisadores da pura plástica, da visão dinâmica são o que há de mais contrário ao escapismo. Para eles a arte não é um mundo à parte, um refúgio à 'torre de marfim', à velha ilusão da 'arte pela arte'. Ao contrário, eles se colocam com os dois pés solidamente fincados nas possibilidades do presente. (Sua arte pretende ser) a cristalização do estado de cultura e de civilização a que o homem potencialmente atingiu., 323

Pedrosa distinguia duas tendências na arte moderna, a saber, a expressionista e a construtiva. Enquanto a primeira evidenciava a revolta do sujeito frente à realidade que lhe escapava, a segunda tinha espírito de coletividade e participava da construção da nova sociedade. A tendência geral da arte abstrata nos Estados Unidos era expressionista. Justamente ali, onde a técnica chegara a resultados sem par e nunca antes vistos, os artistas optaram por expressar a crise do sujeito e não uma solução coletiva. Diante do niilismo de alguns artistas norte-americanos, Pedrosa apontava a via construtiva. No caso de Pollock e de Willem de Kooning, a mensagem niilista de suas obras expressionistas abstratas parecia indicar o assentimento desses artistas com a ordem política do país. O comentário do crítico sobre o abstracionismo norte-americano ressalta a contradição existente entre as conquistas técnicas da sociedade e a ênfase nas apreensões do indivíduo moderno: "Por um paradoxo que dá muito a refletir, dentre os jovens artistas modernos, quase que os únicos que denotam pessimismo (nas obras), certa tendência niilista vivem nos Estados Unidos. É o caso, por exemplo, de um Pollock com seu Lúcifer ou um W. Kooning com Ático, cujo abstracionismo, talvez feito de reminiscências fauvistas ou expressionistas, se manifesta através de um emaranhado de linhas e de manchas coloridas aparentemente arbitrárias, que se poderia traduzir por uma espécie de solução de desespero, de violência, certa aquiescência com a desordem espontânea." 324

\footnotetext{
323 PEDROSA, M. “Atualidade do abstracionismo” In Modernidade cá e lá: textos escolhidos. (org. Otília B. F. Arantes). São Paulo: EDUSP, 2000, p. 179. (parênteses nossos).

${ }^{324}$ Idem, ibidem, p. 181. E Pedrosa se pergunta: "Será isso a revelação do desespero do homem que se sente enredado nos fios da máquina descontrolada? Um indício de sedução da desordem pela desordem, a manifestação inconsciente de um desejo coletivo de autodestruição? Em outros artistas americanos, como
} 
Embora a arte abstrata norte-americana - denominação que servia para unir correntes até mesmo opostas - não fosse a que mais se identificava com as motivações sociais de que falava Pedrosa, se comparada com movimentos e artistas europeus como Theo van Doesburg ou Max Bill, havia nela mais autenticidade e ímpeto inovador que no realismo. Esse era conservador em arte e representado principalmente pelo realismo socialista. Pedrosa comenta: “(O potencial da arte abstrata norte-americana) está na variedade e sobretudo na extrema liberdade de pesquisa de seus artistas, que trabalham não só desamparados dos poderes públicos, como sob hostilidade destes. Mas por isso mesmo ela é uma arte de subversão, de inconformismo, de fé, de participação ativa na vida americana de que é uma expressão autêntica e, sob certos aspectos, a mais promissora. Se os Estados Unidos fossem um país em que o Estado já fosse senhor de tudo e de todos, a 'doutrina oficial' de sua arte seria a que hoje prevalece na Rússia. (...) A verdade nua e crua é que a corrente conservadora em arte é hoje representada pelo chamado 'realismo socialista'. Ela é resultante da contra-revolução ideológica que se veio processando na Rússia desde o isolamento nacional da revolução, quando as forças progressistas européias foram sendo sucessivamente esmagadas até o triunfo wagneriano de Hitler."325

Malgrado as acusações que sofria dos críticos do PCB, Pedrosa reafirmava a ligação estreita entre a revolução comunista nos tempos de Lênin e de Trotski e a arte moderna, em especial o construtivismo. A vanguarda russa tinha estabelecido como meta criar uma arte que fizesse parte dos esforços de construção do homem do futuro e de relações sociais baseadas na coletividade e no sentimento comum e fraterno. Seu mote principal era a aproximação entre o trabalho artístico e o conjunto da produção social. Baseados na idéia de racionalidade e planejamento da sociedade, Rodchenko, Kandinsky e Malevitch não pouparam esforços para que, por meio da revolução interna da arte, eles contemplassem os ideais comuns da revolução russa. Fizeram profissão de fé de sua arte e do comunismo, pois ambos pareciam caminhar juntos para a síntese final e definitiva em que o trabalho seria atividade livre e a arte, parte constitutiva de todas as atividades humanas. Esse foi o objetivo dos esforços sobre-humanos dos que trabalharam pela e na fase inicial da revolução soviética. Pedrosa relata: "Sob estímulo de um Lunatcharsky e de um Bogdanov, Leningrado e Moscou foram teatro, nos

Rothko e seus afins, a tendência abstracionista traz como que uma volta à indefinição, à supressão da linha ou da forma definida, ao mundo pequeno-burguês desestruturado do impressionismo." Idem, ibidem, p. 181.

${ }^{325}$ PEDROSA, M. Op. cit., p. 181. (parênteses nossos). 
primeiros anos da revolução, das maiores experiências artísticas em todos os domínios, desde o teatro e o cinema à música, à pintura e escultura. $\mathrm{O}$ construtivismo moderno nasceu ali com Malevitch, enquanto Kandinsky, diretor das artes em Moscou, tentava globalizar, sob uma orientação realmente revolucionária, não só social como técnica e esteticamente, todas as atividades artísticas."326

No caso da URSS, Pedrosa mostrava que a arte não conseguira por si só transformar o homem e suas experiências revolucionárias foram interrompidas. $\mathrm{O}$ surgimento do movimento contra-revolucionário na política foi seguido da repressão nas artes: "A partida de Malevitch, a partida de Kandinsky que mais ou menos coincidiu com o suicídio de Maiakovski, não se deram por acaso. Era uma reação que, principiando no domínio aparentemente desinteressado da arte, ia terminar na glorificação de Ivã, o terrível, e de Pedro, o Grande, o endeusamento de Stálin, o nacionalismo e patriotismo estilístico na arquitetura como a suprema sabedoria e a volta pura e simples, nas artes plásticas, ao assunto, à imitação da realidade imediata. Quer dizer, entronizava-se no país de Lênin uma estética francamente reacionária, criada outrora pela burguesia, nos seus dias de arrivismo social, cultural e político. Sob o pretexto de luta pela edificação do socialismo, o chamado realismo socialista é apenas a glorificação da burocracia dirigente do Estado soviético. (...) A máquina (Pedrosa refere-se à câmera fotográfica) não idealiza, mas a arte, mesmo a mais realista, é o maior instrumento de idealização da realidade. Os artistas russos obrigados a 'documentar' a atualidade soviética não fazem outra coisa senão idealizá-la, e o que é pior: não ao sabor da própria fantasia, mas ao gosto dos altos dignatários do poder. $\mathrm{Na}$ Rússia de hoje todos são idealizados, o Chefe supremo nas alturas e os operários e o mujique fantasiado de macacão proletário, lá embaixo.”327

Pedrosa acreditava que a tendência construtiva da arte moderna, isto é, o reatamento proposto pela arte abstrata e concreta com as experiências plásticas interrompidas do construtivismo russo, visava à consumação dos anseios sociais depositados, e ainda não concluídos, no advento da revolução russa. A tendência construtiva realizava, imediatamente na arte, o que era imprescindível que se processasse no campo político. Não se tratava mais de recuperar a função documentária da arte, já que a fotografia e o cinema cumpriam-na melhor, e sim de aproximar a

\footnotetext{
${ }^{326}$ PEDROSA, M. “Atualidade do abstracionismo” In Modernidade cá e lá: textos escolhidos. (org. Otília B. F. Arantes). São Paulo: EDUSP, 2000, p. 182.

${ }^{327}$ Idem, ibidem, pp. 182-184. (parênteses nossos).
} 
criação artística da "tecnologia moderna, que criou novos materiais e novos objetos, libertou as cores do suporte objetivo, insinuou novas formas e abriu novas perspectivas à imaginação e à visão humanas". ${ }^{328}$ Assim como essa arte se ligava à produção social, compreendida como o meio necessário para a satisfação das necessidades e a realização plena dos homens, ela se distanciava das funções externas aos seus objetivos mais generosos. Seus lugares, por excelência, eram a imaginação e a visão de mundo renovada. Na análise sobre os móbiles de Alexander Calder, Pedrosa mostrava como o artista desvencilhou-se das coerções práticas e externas para se concentrar apenas na obra: "Com esses materiais industriais não ficou Calder, entretanto, escravo do funcional; ao tratá-los, o impulso da própria fantasia lhes desviou o curso, lhes torceu as formas e com estas o destino utilitário e convencional. Ele sabe, para realce da dramaticidade plástica, como violentar a própria funcionalidade do material. Fez assim da mecânica um sistema a serviço de nada, trabalhando ao deus-dará, para o sonho e a especulação - para não mover coisa alguma, para não ganhar dinheiro." 329

O distanciamento crítico alcançado por Alexander Calder em suas obras não se contrapunha somente ao doutrinarismo político das artes, implementado na URSS, mas também à conveniência política, que não contrariava a predileção e o gosto generalizado das massas pelos modelos de arte consagrados e pelos velhos esquemas perceptivos. Acresce-se a isso o efeito devastador e mais ou menos recente da propaganda mercantil das sociedades capitalistas, que incitava preferências e formava a sensibilidade própria das culturas ocidentais. A tendência construtiva nas artes, e mesmo a arte expressionista abstrata, surgia como uma trincheira contra a transformação da arte em objeto de consumo ligeiro e contra o embotamento estético do homem contemporâneo. A arte autônoma seria a chave para a preservação dos valores da arte, numa época em que ela sofria golpes duríssimos, tanto no regime dito comunista como no capitalista. Da necessidade de preservação das conquistas da arte moderna dependia a capacidade de transformação do mundo em outra via. Pedrosa assim como outros críticos de arte visavam apresentar uma alternativa efetiva e muito mais transformadora pois baseada na imprescindibilidade da formação estética para a realização plena do homem. ${ }^{330}$

\footnotetext{
${ }^{328}$ Idem, ibidem, p. 184.

${ }^{329}$ PEDROSA, M. Tensão e coesão na obra de Calder In Modernidade cá e lá. (org. Otilia B. F. Arantes). São Paulo: EDUSP, 2000, p. 77-78.

${ }^{330}$ O crítico Clement Greenberg, discute, em "Vanguarda e kitsch", a diferença entre a pesquisa estética de vanguarda e o gosto estético generalizado nas sociedades de consumo. Cf. GREENBERG, C. Avantgarde and kitsch. Disponível em: http://www.sharecom.ca/greenberg/kitsch.html. Acessado em: 12-022006. É possível encontrar nesse texto afinidade com a interpretação de Pedrosa sobre a função
} 
A partir de meados da década de 1940 e durante a década de 1950, os escritos de Pedrosa realçaram a importância revolucionária da dimensão estética. Se o reatamento entre arte e produção em massa parecia cumprir anseios democráticos e socializadores no mundo moderno, a dimensão estética era capaz de oferecer aos homens o significado e a devida amplitude da transformação social que se processava. Desde o construtivismo russo até as manifestações mais renovadas da tendência construtiva - entre elas, o concretismo - visavam objetivar o trabalho artístico, inserindo-o na atividade coletiva e emancipadora da sociedade baseada na racionalidade e no planejamento da produção e desmistificando a noção de genialidade criativa. Essa foi a grande contribuição da arte de tendência construtiva, que aproximou o artista do trabalhador. ${ }^{331}$ Tanto na realização da nova arte como na da arquitetura moderna, e portanto na integração necessária delas, encontrava-se a realização do projeto construtivo brasileiro. Otília Arantes comenta: "Mário Pedrosa completaria (...) que foi justamente o (a propensão de arquitetos brasileiros para o dogmatismo de uma disciplina auto-imposta) que lhes permitiu levar a bom termo o seu "papel de militantes". (...) Aliás, após ressaltar a disciplina própria de discípulos e doutrinários, (Pedrosa) explica que um tal dogmatismo (de Lúcio Costa e de Oscar Niemeyer) repousava, contudo, num sentimento verdadeiramente moderno: " $a$ fé nas virtualidades democráticas da produção em massa"', 332

Todo o esforço devotado pelos artistas construtivos na produção moderna visava ampliar a consciência dos homens, motivando novas formas de agir e de compreender a

\footnotetext{
emancipadora da arte moderna. Entretanto, deve-se salientar que a opção que Greenberg faz pelo expressionismo abstrato nos Estados Unidos e a opção de Pedrosa pela arte construtiva no Brasil são ditadas por circunstâncias históricas e sociais muito diferentes. E ambas tem conotações próprias e consequiências diferentes no plano internacional. Se, por um lado, a posição do crítico norte-americano esteve comprometida com a preservação da dimensão estética, por outro, o significado conservador representado pela tendência abstrata da arte nos Estados Unidos se revelou no uso da cultura avançada da época como propaganda do ocidente capitalista como portador e defensor dos valores mais refinados da cultura contra a ação depredatória da URSS. Além disso, ao defender o expressionis mo abstrato, Greenberg reafirmava os valores tradicionais da cultura norte-americana centrada no indivíduo. Enquanto isso, a tendência construtiva defendida por Pedrosa apostava no pólo oposto da relação indivíduosociedade.

${ }^{331}$ Diz Ronaldo Brito: "Não há dúvida que ao Concretismo cabe o mérito (a ele e não às tendências ditas marxistas) de compreender a necessidade de atacar o centro do reduto idealista em matéria de arte: o chamado processo criador." BRITO, R. Neoconcretismo; vértice e ruptura do projeto construtivo brasileiro. Rio de Janeiro: FUNARTE, 1985. p. 60. O comentário de Pedrosa, em 1967, enfatiza a dimensão crítica da arte concreta no que se refere à aproximação dela do campo da produção: "Como sabemos, a arte moderna se apresentou em sua complexidade quando o quadro de cavalete aparece aos artistas como uma totalidade autônoma, e não como até então na velha arte representativa uma superfície destinada a criar a ilusão de uma realidade exterior tridimensional. (...) a justa e fecunda convenção de então, em sua autonomia e na sua concreticidade real". PEDROSA, M. "A passagem do verbal ao visual" In Homem, mundo, arte em crise. (org. Aracy A. Amaral). São Paulo: Perspectiva, 1986, p. 148.

332 ARANTES, O. B. F. Mário Pedrosa: itinerário crítico. São Paulo: Cosac Naify, 2004, pp. 112-113. (parênteses nossos).
} 
realidade. Nisso consistia sua contribuição sem par. Segundo Pedrosa, a mensagem inovadora da tendência construtiva só era possível devido à independência que essa arte gozava frente aos poderes constituídos e ao status quo, capaz de motivar uma alternativa política, econômica e social para o mundo. Com sua especificidade e leis próprias, a arte construtiva produziria uma revolução silenciosa. A ênfase do crítico na importância da dimensão estética - como produtora de nova consciência coletiva - pretendia ser uma resposta à preponderância da Realpolitik no mundo do pós-guerra, onde os ideários de transformação da sociedade eram substituídos pela prática reificadora e pelo pessimismo generalizado causado pela crença na falta de alternativas diante da tentativa frustrada de se implementar o socialismo na URSS, do desencantamento com as conquistas benéficas da ciência e do fim das utopias sociais. Em suma, a arte possibilitaria uma nova percepção do mundo, desenraizando o homem de seu cotidiano empobrecido e promovendo consciência transformadora. ${ }^{333}$

${ }^{333}$ Mário Pedrosa afirmava que a exclusividade concedida aos fatores objetivos não garantia uma alteração efetiva da sociedade e das instâncias de poder. Não havia possibilidade de uma revolução efetiva sem a colaboração dos fatores objetivos e subjetivos. A aposta de Pedrosa incidia naquilo que a análise economicista deixara de lado, a formação de consciência e a liberdade, por considerar que a transformação principal da sociedade referia-se à superação do modo de produção capitalista vigente e que ela traria necessariamente por si, em fase posterior, a conquista da liberdade almejada e a emancipação da consciência. Os descaminhos da revolução na URSS interditaram aquelas expectativas. Lá o que se via, com a nacionalização da produção e com o monopólio da distribuição realizado pela burocracia estatal, era justamente a exploração do homem pelo homem, a manutenção das relações de poder e 0 desenvolvimento de um Estado nacional conservador perseguindo objetivos instrumentalizados, segundo uma racionalidade que transcendia os interesses do homem. Tanto o mundo capitalista do Ocidente como a URSS eram regimes desumanos. A convicção em um finalismo histórico inevitável, no qual o capitalismo seria suplantado inevitavelmente pelo socialismo, estava em derrocada. O processo revolucionário que levou o proletariado ao poder na Rússia foi interrompido e, em seu lugar, surgiu um estado controlado por técnicos. Para Pedrosa, a raiz dessa situação encontrava-se no processo histórico de alienação do homem, tanto no âmbito econômico como no ideológico.

No âmbito ideológico, expressavam-se os fatores subjetivos e a explicação da tomada de consciência do homem sobre sua liberdade. A gênese dessa consciência iniciara-se com o fim da unidade entre ordem divina e ordem secular, com a "desmitologização do universo" em que o homem é obrigado a se guiar por si próprio sem o auxílio de uma ordem externa na sociedade e no mundo garantida por qualquer entidade divina. Pedrosa comenta: "o resíduo que ficou do esvaziamento dos céus é um elemento inassimilado. O mistério dos céus despovoados é um dos tormentos, uma das angústias do homem moderno. Expulsou os deuses do infinito, e ficou com medo do vazio incomensurável". PEDROSA, M. "O mundo perdeu seus mitos" (depoimento de Pedrosa a Paulo Mendes Campos) In Diário Carioca, Rio de Janeiro, ano XX, $2^{\mathrm{a}}$ seção, 
n5.943, novembro de 1947. (primeira página). À medida que se consolida a consciência da liberdade aumenta também seu antagonismo em relação à ordem social e o isolamento cada vez maior do indivíduo. Em especial, o isolamento do homem coincidia com sua liberação para o mercado de trabalho e com a supressão de seu status dado pela tradição. Ganhava-se em consciência de liberdade, o que se perdia em clareza a respeito da lógica interna da estrutura e das verdadeiras motivações das relações sociais.

No âmbito econômico, tinha-se a explicação do processo de condução da sociedade para objetivos que não são por ela traçados, mas sim pelos interesses econômicos. Por um lado, o homem moderno liberta-se das antigas instituições da tradição; por outro, esse acréscimo de mobilidade e de consciência não lhe garante um controle equânime sobre a organização da sociedade. A partir do advento da sociedade moderna inaugurouse também o aumento crescente do antagonismo entre a conquista da liberdade pelo homem e a perpetuação de um poder social para além da capacidade humana de direcionamento e de intervenção. Esse poder era a expressão dos fatores objetivos e a verificação da transfiguração da realidade sob a economia capitalista. Mário Pedrosa constatava a influência direta do âmbito econômico sobre o entendimento e a organização da vida moderna: "o traço supremo do regime capitalista, que marca a cultura de nosso tempo, de suas deformações, é dar aos homens uma finalidade externa às suas próprias necessidades vitais: a procura do lucro pelo lucro, a necessidade incessante de acumular, de inverter capitais, ininterruptamente, de não ser vencido no mercado, de produzir para produzir". Idem, ibidem.

Assim, a investigação da produção simbólica fazia-se tão necessária como a crítica da forma das relações sociais de produção sob a égide do capitalismo. Tanto uma como outra colaboravam para a manutenção do sistema e, principalmente, para o predomínio de um poder acima do social cada vez mais autônomo. Aqui, em concordância com o pensamento e a análise de Marx, na primeira parte do livro I de "O Capital", Mário Pedrosa asseverava que o processo de alienação do homem ganhava tal dimensão que tanto a burguesia quanto o proletariado perdiam o controle sobre a organização e o direcionamento da sociedade. Com o privilégio de uns em detrimento do trabalho de outros, as relações econômicas tornavam-se o verdadeiro agente e motor do encadeamento histórico. Da possibilidade de se tornar sujeito, o homem passava a ser objeto da história. Pedrosa diz: "as relações sociais impostas pelo capitalismo alienaram o homem, e só deixaram em presença um do outro o empregador e o empregado, o capitalista e o assalariado, o contratante da força de trabalho e o contratado, o vendedor e o comprador, o negociante e o freguês. A grande crise moderna é a alienação do ser humano (...). Foi (Marx) (...) acusado tão levianamente de um materialismo de vistas curtas, que se ergueu, desgrenhado de revolta e paixão humana, contra a inumanização da nova sociedade, contra a "coisificação" do homem, provocada pelo capitalismo". Idem, ibidem, p. 02. (parênteses nossos). O problema da ideologia tornava-se central para os estudos do pós-guerra. Em 5 de abril de 1955, Pedrosa publicou um ensaio intitulado: "O poder nacional - as ideologias e sua significação para o poder nacional". Nesse ensaio, ele apostou na fundação de um processo cognitivo capaz de levar adiante a crítica dos prejuízos ideológicos e dos pressupostos teóricos da nova ordem mundial. Tal processo cognitivo ancorava-se na tentativa de formulação de respostas para a série de eventos que minaram as experiências socialistas na primeira metade do século XX, entre eles: a derrota do comunismo na Rússia e a formação dos estados totalitários na Europa. Todos esses eventos foram explicados por Trotski, no final de sua vida, como conseqüência de um período transitório e fugaz de obscurecimento da luta de classes no 
Preocupado com a defesa da arte independente como exercício livre da consciência, o que garantiria a possibilidade de se criarem alternativas críticas à predominância das práticas sociais estabelecidas, Pedrosa assim como outros críticos militantes de seu tempo, entre eles os norte-americanos Meyer Schapiro e Harold Rosemberg, lutou contra a instrumentalização da arte. Ele acreditava que mesmo sob o encalço capitalista, a arte tinha margem maior de atuação no Ocidente do que na URSS. As manifestações novíssimas da arte abstrata e depois do concretismo, inauguradas no Brasil a partir do final da década de 1940, possibilitavam o vislumbre de uma transformação social profunda inaugurada pela coesão entre estética e o conjunto da produção social. Por isso, Pedrosa apostou na arte independente e não na arte pela arte. A tendência construtiva seguida pela arte brasileira indicava uma via diferente daquela consolidada pelo expressionismo abstrato norte-americano. ${ }^{334}$ Talvez por sua crença nas possibilidades emancipatórias da nova arte, Pedrosa entendeu mas não conseguiu erguer barreiras contra a utilização, inclusive política, da arte moderna no Ocidente capitalista, sobretudo pelos Estados Unidos. De fato, a arte abstrata fora eficiente para combater o realismo e o uso político que se fazia dele, entretanto a arte moderna não se conseguiu, especialmente o abstracionismo e o concretismo do pós-guerra, trilhar um caminho próprio, integrou-se às práticas sociais estabelecidas e não proporcionou uma mensagem anticapitalista evidente e promissora. Ao final de tudo, quando da emergência da Pop $A r t$, Pedrosa reconheceu que a arte de tendência construtiva não conseguiu reverter os mecanismos nem dotar de racionalidade os processos de produção social. Todos os produtos da vida humana, inclusive a arte, tinham sido absorvidos pela sociedade de consumo.

cerne da sociedade moderna. Passada a guerra e com a ajuda da militância comunista, o conflito entre proletariado e burguesia se acirraria novamente e dele adviria a revolução proletária internacional e a deposição da burocracia contra-revolucionária na Rússia. Esse cenário pós-guerra não se confirmou e Pedrosa teve de analisar a formação de estados nacionais autônomos em franco antagonismo com a sociedade.

${ }^{334}$ Cf. BUCHLOH, B. H. D. "Cold war constructivism" In GUILBAUT, S. Reconstructing modernism: art in New York, Paris and Montreal, 1954-1964. (editado por S. Guilbaut). Massachusetts: MIT, 1990, pp. 85-112. Embora o autor assuma a defesa de uma arte nos moldes produtivistas - baseados na exigência de que a arte se filie à produção não importando o custo disso -, ele também traz para discussão sobre o contexto das artes no pós-guerra, a interdição política da tendência construtiva nos Estados Unidos. 


\section{$\underline{\text { A reivindicação de mais consciência e a função da arte moderna }}$}

Uma vez mais, Pedrosa retoma a questão da democracia e da liberdade no ensaio “A arte e os políticos" ${ }^{335}$, que discute a significação da arte moderna e seus pontos de contato com a política. Nele, liberdade e ação consciente são essenciais para uma transformação social profunda, sem as quais toda prática humana estaria ameaçada. É preciso dizer que a partir do anseio manifesto pela liberdade no semanário Vanguarda Socialista, como fator decisivo na mutação das relações de classe e das práticas sociais, Pedrosa enfatizou, nos anos seguintes, a importância das atividades desinteressadas do espírito. Essa prerrogativa da noção de descondicionamento dos processos criativos era fonte para um desenvolvimento da análise crítica-objetiva, que visava não apenas à negação das visões de mundo subordinadas à prática social em vigor, mas também, à construção de um projeto alternativo de civilização. Por conseguinte, se o interesse de Pedrosa pela liberdade tinha respaldo nas proposições de Rosa Luxemburgo, o combate pungente do falso processo de conhecimento encontrava identidade com o pensamento de Karl Manheim, quando este fez a crítica da relação degenerativa entre pensamento e a prática estabelecida no capitalismo e nos regimes totalitários.

Não era para menos, pois tanto o fortalecimento da atuação independente dos Estados e dos poderes públicos recém-constituídos no pós-guerra, quanto a pulverização das ações coletivas em simples ações individuais tornavam necessária a defesa da democracia contra impulsos sociais destrutivos. Cada vez mais, a igualdade política e a liberdade eram encaradas como valores sem os quais nem a arte nem qualquer outra ação consciente poderiam sobreviver. Toda fonte de distorção ou integração condicionada da atividade crítica deveria ser denunciada e combatida. Pedrosa considerava necessário assegurar na vida contemporânea, pela consciência e pelo exercício da liberdade, o desenvolvimento "das atividades desinteressadas do espírito (...) numa época de tarado utilitarismo", afirmando que, "o espírito criador, a verdadeira cultura não florescem senão num clima de liberdade. Sob as tiranias, é claro, os gênios não desaparecem. Ao contrário, muitas vezes irrompem - pela fatalidade mesma de ter

\footnotetext{
${ }^{335}$ PEDROSA, M. “A arte e os políticos” In Tribuna da Imprensa, Rio de Janeiro, 25 de outubro de 1952, p. 08 .
} 
de vencer resistências obscurantistas (...), mas só na liberdade, na democracia, os frutos solitários do gênio permanecem, frutificam e se socializam." 336

Ainda que os artistas e suas grandes obras nasçam tanto nos regimes tirânicos como na democracia, apenas nesta última seria possível um aprimoramento estético em sentido social. Tão somente com liberdade e democracia, a realização dos desígnios mais recônditos do mundo artístico poderia ser difundida e intensificar a troca imprescindível entre os aspectos individuais e coletivos da experiência humana. Todas as atividades desinteressadas do espírito proporcionavam, pelo desenvolvimento independente dos condicionamentos sociais, uma superação das práticas humanas estabelecidas. Na sociedade contemporânea, travava-se o embate enérgico entre uma nova forma de conhecimento baseada na percepção e uma racionalidade operativa e condicionada. Uma acompanhava com exclusividade as exigências materiais assegurando a permanência e o aperfeiçoamento do poder da esfera pública ou do Estado sobre os indivíduos -, outra sustentava a superação do mecanicismo social pela ação da consciência.

A igualdade política era condição prévia para que o espírito criador ou a consciência formadora atuassem no sentido de estabelecer não apenas uma sensibilidade renovada, senão também relações sociais inéditas. Donde Mário Pedrosa assevera, em objeção tanto ao vigor destrutivo da institucionalização como à incapacidade dos regimes totalitários: "a superioridade democrática consiste em criar o clima espiritual mais capaz de dar estrutura, forma e estilo às grandes culturas, às culturas autênticas que marcam os povos com fisionomia própria ou dão a todos os estágios de civilização, mesmo os mais primitivos, o privilégio de sobreviver os milênios." 337 Contra o mecanicismo sócio-econômico, uma defesa possível consistia em manter o avanço das atividades livres não apenas para denunciar a subordinação do homem às determinações históricas do capitalismo e a incapacidade de controle e de direcionamento racional nos regimes políticos vigentes, mas também para insuflar vida no esquema de relações sociais quase inanimadas a fim de que se iniciasse o processo construtivo de uma nova sociedade.

Nessas condições inauditas, cabia ao homem criar produtos culturais independentes - baseados nas condições favoráveis da democracia e da liberdade - para uma mutação substancial do mundo e, com isso, evitar a prevalência do utilitarismo

\footnotetext{
${ }^{336}$ PEDROSA, M. Op. cit., p. 08.

${ }^{337}$ Idem, ibidem. p. 08.
} 
afeito à lógica da relação entre coisas, próprio de um racionalismo frio e eficiente que se tornava, em última instância, ameaçador à vida. A conservação desse estado de coisas significava tanto uma progressiva anulação do homem, obstruindo sua consciência formadora, como uma distorção de sua apreensão objetiva. Assim, a política devia passar por uma revisão de seus objetivos e a consciência seria o primado de uma nova política feita de baixo. Explica Pedrosa: "A política em nossos dias tende a tornar-se cada vez mais uma técnica e muito menos um combate pela elevação material e cultural do povo. Os poderes públicos à medida que crescem, que intervêm por toda parte, que abarcam todos os aspectos da vida moderna se vão tornando monstros irresponsáveis de mil cabeças, movidos apenas por uma norma - a da eficiência."338

Em contraposição a toda prática social, que visava à máxima concretização de objetivos produtivos em benefício das classes dominantes, as atividades livres encontravam-se dissociadas das relações sociais estabelecidas e seriam o fator negativo necessário de superação do viés exclusivamente econômico na formação de uma nova sociedade para além das manifestações empobrecidas da experiência humana. Por sua vez, as atividades livres renunciavam a todo aperfeiçoamento do mecanicismo social que aumentasse a subordinação humana aos interesses do lucro, que de forma infalível enfeixavam as rotas possíveis de atuação restringindo-as na política ou na economia. Entre essas atividades, a arte tinha função essencial no processo de reeducar o homem pela ampliação de sua sensibilidade embrutecida, o que demandava uma amplificação de sua consciência e potencialidade cognitiva. Segundo Pedrosa, a arte podia romper com esse ciclo de produção e reprodução da sociedade: "Contra esse novo Frankestein o homem é sem defesa. Ou por outra, sua defesa consiste em estimular as atividades desinteressadas, mesmo as atividades pueris. No campo dessas atividades, a de força resistente maior é sem dúvida a arte moderna., 339

Se antes do advento das vanguardas artísticas havia uma relação muita vez de cumplicidade entre arte e ordem instituída, agora cabia às artes plásticas - em sua resistência à incorporação nas práticas sociais estabelecidas - uma função mais nobre: cultivar uma nova percepção da realidade e incentivar todo tipo de experiência capaz de não se limitar às estruturas mentais do dia-a-dia. Conclui Pedrosa: "Para Mondrian, para Gropius, a única salvação do homem em face da máquina está em reeducá-lo esteticamente. Em fazê-lo parar sua corrida sem sentido, em sua afobação cotidiana,

\footnotetext{
${ }^{338}$ PEDROSA, M. Op. cit., p. 08.

${ }^{339}$ Idem, ibidem, p. 08.
} 
para que contemple, se detenha não apenas diante de um quadro, de uma escultura ou de um monumento, mas também diante dos humildes objetos que o envolvem, atento a que as coisas sirvam naturalmente aos fins a que se destinam, as formas sejam adequadas às funções e a ordem derive da sincronização da imaginação com a necessidade."’340

A procura pela expressão justa, por parte de Mário Pedrosa, entre função e forma indicava a realização de um ideal de transparência na compreensão e na ordenação do mundo, que garantia as condições e motivações reais de produção e reprodução social e propiciava a construção de outro modo de vida. Evitava-se, com isso, a insuficiência do plano único da ação para resolver as novas dinâmicas engendradas pela instituição de valores sociais atinentes à manutenção das estruturas de poder. Essa dimensão do pensamento deveria ser posta à prova, sob pena de ineficácia da ação transformadora. Revelar o vínculo existente entre pensamento e prática social estabelecida era sinal de um processo crítico que se completava em duas direções e também da importância atribuída às atividades livres, diante da ação e do pensamento condicionados à ordem vigente. Nesse sentido, a arte moderna negou os preceitos acadêmicos do século XIX e a velha dinâmica entre forma e conteúdo da obra para afastar a influência verbal ou literária predominante.

Para Pedrosa, a arte moderna era expressão da adequação perfeita entre o espírito e a matéria. Essa adequação restituía à razão um significado mais amplo, derivado da ênfase na experiência humana e na qual se restabelecia o contato com o mundo; com isso, far-se-ia o coroamento da estética, que sensibilizaria a razão. Se a experiência humana empobrecida reafirmava na mesma medida as versões mais simplificadas da validade e da predominância do postulado pragmático, era preciso revelar - e por que não através da evidente formação de consciência pela arte? - quanto existia de falso na exigência prática e a serviço de quem ela se encontrava. Assim, o momento da consciência tornava-se a passagem tanto do fetichismo para o valor de uso como da aparente organização racional do mundo para uma unidade verdadeira entre arte e razão. Não se tratava aqui de um problema supérfluo ou ligado em demasia a uma teoria do valor, mas da tentativa de dar transparência às dicotomias forjadas entre homem e mundo, razão e experiência.

A arte moderna convertia-se na negação da relação obscurecida entre entendimento e sensibilidade ou no momento de consciência, que não se deixava lograr

\footnotetext{
${ }^{340}$ PEDROSA, M. Op. cit., Idem, ibidem, p. 08.
} 
pelo antagonismo entre imaginação e necessidade, a fim de que fosse possível uma ação efetiva na construção de um projeto civilizatório renovador. Da arte e das atividades livres tinha-se, ao contrário do que se poderia supor, um ponto de vista crítico-objetivo novo e uma alternativa eficaz para a superação da ordem e do poder vigentes. Eis por que Pedrosa indicava a conquista de uma razão sensível como ponto de partida para a função emancipadora da arte, sem a qual tanto o pensamento como a ação estavam condenados a uma separação nociva: "Desde Marx e Rimbaud, a realidade e a poesia ou se fundem ou o mundo entra em caos. Não é possível a dicotomia entre ação, domínio por excelência da política, e o pensamento, que abrange desde as intuições mais abstrusas da matemática moderna às criações mais abstratas de um Klee ou de um Max Bill. Os políticos de nossos dias ou concorrem para uma harmonia ou estão trabalhando para fazer saltar o mundo que pretendem estar dirigindo, em mil pedaços, num desses dias." 341

A tarefa da arte moderna inscrevia-se na transformação profunda da sensibilidade do homem e, por isso, também implicava uma alteração da visão de mundo consolidada e da relação cognitiva recrudescida. Tratava-se de apostar na revolução interna da arte e no aprimoramento pleno de um novo processo cognitivo sob a égide da arte contra o racionalismo abstrato da sociedade burguesa. Em um de seus depoimentos na década de setenta, Pedrosa comentaria: “A 'arte moderna' ia mostrar-se assim mais do que uma simples moda ou escola, como qualquer das inúmeras que passaram pela história contemporânea, (...) um movimento cultural da maior transcendência. Primeiro que tudo vinha revelar o que se havia esquecido no curso do desenvolvimento da civilização burguesa, de seu racionalismo abstrato, conseqüente à supremacia da economia capitalista com suas relações de produção fundadas no mercado, onde as coisas perdem a realidade concreta, e transferidas ao plano das superestruturas em escala mundial: que a Arte em nenhum momento da evolução humana foi monopólio ou produto direto dos progressos econômicos e intelectualistas. Foi, entretanto, em nome dessa supremacia econômica e política e dos conhecimentos que adquiriam sistematicamente reduzidos a normas lógicas esvaziadas de seu conteúdo contraditório, que as burguesias nacionais européias passaram a proclamar ter também a

${ }^{341}$ PEDROSA, M. Op. cit., p.08. 
supremacia e o monopólio da 'grande' arte, das 'belas-artes', desde o advento do chamado milagre grego, em que querem encontrar suas origens ou seu modelo."342

Contra esse estado miserável da civilização burguesa é que a arte moderna se insurgira. Ela lutava contra a manutenção de uma ordem social fundada no descrédito da experiência direta e estreita entre homem e mundo, contra os preconceitos intelectualistas baseados na pretensão de onisciência do indivíduo burguês autocentrado e, em suma, contra a sociedade de mercado em que tudo deveria ser redutível aos parâmetros da prática ou à moral do uso. Para Pedrosa, a arte moderna nascia da contradição que se instaurava entre a tradição ossificada da cultura européia e as descobertas - feitas por antropólogos, etnólogos, psicólogos, etc. durante a expansão capitalista da Europa em busca de novos mercados - de formas expressivas e impactantes realizadas pelas culturas dos povos ditos "primitivos". Neles, a valorização das experiências perceptivas e do caráter fisionômico dos objetos revelava uma relação mais próxima entre sujeito e objeto em franca oposição ao conhecimento instrumental do homem moderno. Cabia à arte moderna realizar uma mutação profunda da sensibilidade e da compreensão consolidadas pelo pensamento etnocêntrico, enquanto o homem ocidental transformava a base econômica e social dos povos "primitivos" ou excêntricos.

Pedrosa conclui: "No entanto, por uma dessas reviravoltas dialéticas da história, a própria expansão imperialista que se inicia pelo fim do século vai abrir à arte ocidental o contato com as culturas dos povos primitivos, ainda em estágios tribais, comunitários ou pré-capitalistas. Desse contato é que, se não nasce, desenvolve-se o que será a 'arte moderna'. O impacto desse contato foi tremendo sobre as Ciências Sociais, da Sociologia à Antropologia, à Etnografia, à Psicologia Social que até então se desenrolavam independentemente das investigações de campo, por analogias e deduções conforme a lógica formal, de natureza idealista ou mistificadora, ou por algumas induções e intuições geniais isoladas de seus sábios. (...) A idéia da superioridade branca sobre os outros povos da periferia econômica e cultural começava a ser batida em brecha pelo próprio desenvolvimento das Ciências Sociais e culturais na época imperialista. A arte moderna é em grande parte resultante dessa dialética cultural. Assim, ao mesmo tempo em que o imperialismo conquista, explora e destrói as economias, o viver e as culturas autóctones desses povos 'bárbaros', a arte que se

\footnotetext{
342 PEDROSA, M. “Às vésperas da Bienal” In Homem, mu ndo, arte em crise. São Paulo: Editora
} Perspectiva, 1986, p. 285. 
começa a fazer no ocidente vai enriquecer-se com a contribuição das forças culturais até então insuspeitas desses mesmos povos." 343

O painel "Tiradentes" de Portinari pretendia dar relevância à função comunicativa da arte. Ela realizar-se-ia através da composição visual didática e da excessiva clareza no tratamento do assunto. Esses aspectos de sua proposta distanciavam-se da função plástica estrita, ao mesmo tempo em que formavam a base para uma compreensão acessível da obra pelo público. Se bem que a atitude de Portinari implicasse uma concepção precisa sobre a função comunicativa da arte, tratava-se de uma operação mais política que estética. Por isso, a insistência do Pintor na execução do painel de Tiradentes sob o crivo do realismo histórico beneficiava outra coisa que não precisamente a arte. Para Pedrosa, a preocupação política e social assumida por Portinari deslocava a pergunta - o que a arte comunica? - e interditava sua função. Isso porque o enfoque sobre o realismo histórico como meio de alcançar a expressão simplificada na composição visual e a clareza no tratamento do assunto refreava a mensagem estética advinda com exclusividade da apuração interna da atividade artística.

Por sua vez, Pedrosa salientava seu interesse pela primazia da mensagem estética sobre a influência do campo político e social na arte. Foi a inquietação causada por essa matéria que levou o crítico à reavaliação da obra de Portinari e que marcou, daí por diante, o desenvolvimento de suas idéias. Sua posição sobre a função comunicativa da arte pode ser melhor compreendida com o ensaio, publicado no Jornal do Brasil em 1957, intitulado "Comunicação em arte". Nele, a conjuntura recente da morte de Diego Rivera trazia o ensejo para mais uma análise sobre o Muralismo Mexicano, em comparação com a voga então atual do Tachismo. De forma indireta, fez-se o cotejo da posição artística de Rivera - e, por extensão, a de Portinari - com a solução renovada apresentada por Pedrosa para o problema da mensagem estética, na qual ele explicitou tanto o que consiste a comunicação promovida pela arte como o ponto de vista da recepção da obra pelo público. Esses dois aspectos do problema refletiam tanto as dificuldades apresentadas pelas várias manifestações artísticas em favor da importância do conteúdo social, como davam testemunho de uma alternativa consistente contra o crescimento da influência do subjetivismo na arte moderna.

\footnotetext{
${ }^{343}$ PEDROSA, M. Op. cit., pp. 285-6.
} 
No ensaio supracitado, Pedrosa tentava refutar a constante argumentação de que ao se afastar do público, a arte moderna desumanizourse. Esse ponto de vista defendido por vários intelectuais de diferentes matizes, entre eles Wladimir Kemenev e Bernard Myers - assentava-se na premissa, revelada pelo estudo de movimentos artísticos do passado como o romantismo, de que era possível uma aproximação efetiva entre arte e público. Tornava-se fundamental o estudo sobre a adequação entre a manifestação artística e a capacidade de compreensão dela pelo público. Além disso, para uma parte daqueles intelectuais, a arte moderna sinalizava um novo período em que a divisão da sociedade em classes advinha não apenas do jugo econômico, mas da dificuldade de compreensão do fenômeno artístico. Nesse contexto, um dos fatores implicados na desumanização da arte era justamente o fato de ela ser artigo compreensível para uma elite, mas não para o grande público. Assim, o aporte sobre a função comunicativa da arte levava de modo irremediável à elucidação de qual devia ser a qualidade de sua mensagem e para quem ela se destinava.

Embora não negasse a cisão entre público e arte nem mesmo as diferenças de apreciação do produto artístico na sociedade, Pedrosa acreditava que a arte moderna continha uma mensagem generosa. Com certeza, o problema da comunicação na arte derivava de uma compreensão nova partilhada por poucos, que se distanciava da preocupação de retorno ao gosto geral do público e que fixava uma posição contrária aos esforços simplificadores da mensagem artística para facilitar seu acesso e sua compreensão. Constituía um verdadeiro contra-senso exigir que o esforço renovador da arte moderna se igualasse com as práticas já estabelecidas, com o gosto consolidado na apreciação da arte tradicional. Nesse sentido, afirma Pedrosa: "A arte moderna rompe, realmente, com velhos cânones artísticos consagrados e exige, por isso mesmo, do espectador, uma compreensão mais ativa que a arte tradicional, já perfeitamente digerida, pode exigir." ${ }^{344}$. Esse diferencial resultante da arte moderna não se resumia apenas a seu caráter inovador, de manifestação recém-chegada, mas também à sua tarefa justa de descondicionamento do gosto e da percepção fixada em favor da conquista de outros parâmetros de validação da arte com seu tempo, com o descortinar de uma nova época.

A versão americana de Myers para o problema da comunicação na arte resumiase à subtração de parte do potencial inovador inscrito nos princípios criativos dos

\footnotetext{
${ }^{344}$ PEDROSA, M. "Comunicação em arte” In Política das artes, (organização Otília B. F. Arantes). São Paulo: EDUSP, 1995, p. 107.
} 
artistas modernos a fim de que fosse possível aproximar mais a arte da sociedade. Para esse autor, o desenvolvimento da arte moderna criava condições para o surgimento do artista como detentor de uma compreensão desajustada em relação aos padrões sociais. Isso explicava a ruptura do artista com a sociedade e, principalmente, com o gosto consolidado do público. O artista era definido por Myers como um unusual e fazia-se necessário reabilitá-lo para que sua obra pudesse se aproximar do senso comum e da vida cotidiana. Pedrosa observa: "Eis aí uma proposição vaga e eclética. Encontrar um meio-termo para encher o fosso entre o público e o artista é esforço inócuo, pois em arte não há conciliações nem arranjos externos" e, tal proposta, ao pretender que o artista fizesse "concessões no plano da criação ao gosto público, ou aos preconceitos dominantes" ${ }^{, 345}$, transformava-se na verdade em uma tentativa de institucionalizar a arte moderna.

O meio-termo na expressão artística seria a conciliação entre a arte convencional - acadêmica - e a arte moderna. Um exemplo disso era o Muralismo Mexicano. Myers mostrava-se interessado, em particular, pela voga da pintura mural moderna que vigorara nos Estados Unidos durante o período da Grande Depressão, pois os muralistas modernos enfatizaram o aspecto comunicativo - entenda-se discursivo - na obra de arte em detrimento das preocupações com a pesquisa da sensibilidade contemporânea. Assim, a pintura tinha acima de tudo a função de transmitir uma mensagem política. Comenta Pedrosa: “A estética dos artistas mexicanos era generosa: trazer a arte para a praça pública e abandonar o quadro de cavalete pelo mural, a serviço das idéias da revolução política por que passava o país. Para que o povo os compreendesse, acharam então os Rivera, Orozco e cia. de tornar-se bem 'legíveis', isto é, terra-à-terra, com temas os mais elementares possíveis e tratados pelos meios mais convencionais." 346 Aqui, é interessante registrar, nota-se muita semelhança com a descrição da dificuldade básica enfrentada por Portinari, quando tentava conciliar conteúdo e forma na solução plástica.

Aquele aspecto comunicativo oferecido pelos muralistas, que Myers tratava como um avanço inicial para a aproximação definitiva entre arte e sociedade, representava, segundo Pedrosa, a culminação do processo obliterador e degenerescente da função comunicadora da arte. Ao contrário da posição do intelectual norteamericano, Pedrosa sustentava que a tarefa da arte era, acima de tudo, fugir do gosto

\footnotetext{
345 PEDROSA, M. Op. cit., p. 110.

${ }^{346}$ Idem, ibidem, p. 110.
} 
público consolidado, com a meta de alcançar um parâmetro mais alto de consciência e cultivar uma compreensão mais complexa nesse público. Tanto os artistas mexicanos como Portinari não conseguiram escapar à instância das práticas sociais e da consciência estabelecidas, pois tentaram adaptar a expressão comunicativa da arte aos jargões de um discurso político pouco esclarecedor e "exageraram em tudo: na pregação bem simplificada, na descrição banal das cenas, no anedotário. As deformações obedeciam ao propósito de ensinar e mostrar quão maus eram os ricos ou poderosos, contra quem se fazia a revolução, e quão bons e belos eram os pobres, os índios, as vítimas das injustiças sociais e da opressão. Quer dizer, lançaram mão do exagero da caricatura e da 'clareza' da vulgaridade. O resultado foi a demagogia na expressão, tão mal convincente em arte quanto em política ou em ética." $" 347$

Não há facilidades na elaboração da arte nem a função comunicativa reduzir-seia à expressão artística simples para que fosse captada com facilidade pelo espectador. Como Pedrosa dissera, a arte moderna exigia uma posição diversa do espectador, menos contemplativa ou passiva e mais atenta à feitura da obra e capaz de discernir os elementos constituintes de uma nova sensibilidade. Não se tratava de rebaixar o tratamento das questões estéticas com o emprego consolidado da expressão artística tradicional, mas de elevar o gosto público e convidar o espectador a uma postura mais objetiva e crítica, uma vez que a comunicação efetiva da arte moderna com o público almejava formar consciência através da transformação estética do homem e evitar a manutenção das práticas artísticas mecânicas. Assim, o problema do afastamento entre arte e sociedade não seria resolvido pelo aspecto didático do tema nem pelo recurso à perspectiva renascentista, numa tentativa de "que o artista se adapte ao gosto geralmente imaturo ou estratificado do público, seja burguês ou proletário. A mesma experiência fracassada no México foi feita, depois, com o chamado "realismo socialista'," 348

O problema da comunicação na arte não se reduzia apenas à transposição na obra de uma mensagem para o público, com o intuito de lhe oferecer uma história "legível" ou de conduzi-lo para esta ou aquela conclusão. Tampouco cabia ao artista moderno, como tarefa fundamental, submeter-se ao gosto público, e sim "ampliá-lo, vencer os preconceitos dominantes e propor novos estalões de sensibilidade, que irão posteriormente se revelar mais consentâneos com a própria época."349 Esse novo

\footnotetext{
${ }^{347}$ PEDROSA, M. Op. cit., pp. 110-111.

348 Idem, ibidem, p. 111.

${ }^{349}$ Idem, ibidem, p. 110.
} 
paradigma para a função comunicativa da arte baseava-se tanto em sua capacidade educadora como no empenho do espectador para desvelar - através da arte - a nova sensibilidade de sua época. Era justamente essa relação recíproca entre artista e público que garantia o processo formador de consciência. Não se tratava, pois, da necessidade do artista de comunicar um conteúdo ou de transmitir uma mensagem, mas compartilhar com o público a perscrutação de uma sensibilidade hodierna através da elaboração de elementos artísticos puros.

Em 1952, depois de ter investigado os fundamentos cognitivos da percepção com o aporte dos estudos da Gestalttheorie, Pedrosa se detém na questão do impacto comunicativo e da recepção da obra pelo público. Se a tarefa essencial da arte moderna era comunicar padrões perceptivos consentâneos com as mudanças fundamentais de nossa época, para que isso se efetivasse era preciso não só transpor a influência do padrão consolidado, como também ir à raiz das condicionantes sociais envolvidas no gosto público em geral. Na polêmica com Ibiapaba Martins, um ideólogo brasileiro do realismo socialista, que exigia que a arte deveria destinar-se às massas e não à elite, Mário Pedrosa comentava: "na realidade cotidiana, as massas não mostram nenhum interesse pelas artes. Aliás as chamadas elites também não mostram interesse mais profundo por elas. O que interessa às massas é o cinema, é o futebol, o box, o circo, o teatro chulo ou vaudevillesco, o carnaval. O grande móvel delas é divertir-se., ${ }^{350}$

A arte moderna encontrava de imediato um abismo entre sua tarefa de cultivo da sensibilidade e o próprio público. Além da influência notória da arte acadêmica sobre o gosto em geral e sobre a percepção, Pedrosa definia como o principal fator da separação entre arte e público, o interesse sobretudo deste pelos acontecimentos externos, naturais ou sociais, mais do que pelas experiências interiores, idéias e sentimentos. Isso ocorria por causa da subordinação da consciência à exterioridade, que inviabilizava todo processo cognitivo amplo, em favor de um racionalismo prático e instrumental. Donde a constituição da nova socialidade entre os homens, pautada pelas necessidades práticas da vida, levava à negação tanto da própria interioridade do homem como de tudo que não fosse útil ou não visasse lucro. Diz Pedrosa: "A civilização burguesa, nas suas expressões mais felizes, é uma civilização de extrovertidos. A exteriorização é a sua característica mais geral. O ritmo acelerado da vida moderna por sua vez não deixa ao

\footnotetext{
350 PEDROSA, M. "Arte e revolução" In Homem, mundo, arte em crise, (organização Aracy Amaral). São Paulo: Editora Perspectiva, 1985, p. 246. Nessa edição, o artigo de Pedrosa é datado como de 1967, mas na verdade trata-se de um escrito para o jornal Tribuna da Imprensa em 29-03-1952.
} 
homem tempo para contemplação. E pintura, como escritura, exige contemplação. (...) A vida interior do homem, entretanto, se destrói de dia para dia, à medida que os meios de difusão, de comunicação e de expressão cada vez mais mecanizados se multiplicam (...).,"351

De sua parte, a transformação social visava eliminar a exploração do homem pelo homem e assim abolir toda propriedade privada dos meios de produção. Com ela, criavam-se as condições para uma vida coletiva e igualitária, na qual se integrava por extensão e sentido comum - conforme o exemplo do ideal na arquitetura moderna - o espaço público e o privado. Tratava-se da instauração de uma outra sociedade correlata à realização do ideal de transparência ou de pureza na arte. Em nenhum instante, confundia-se a unidade conquistada entre o indivíduo e a coletividade com a negação da consciência, da vida interior do homem ou da individualidade. Contudo, Pedrosa avaliava a conjuntura histórica em que a transformação social não ocorria nas bases econômicas do sistema produtivo, mas na dimensão da consciência. Sem o concurso íntegro da consciência, não haveria mudança nem social nem política profundas: " $O$ paradoxo de nossa época é que os meios de produção ainda não foram socializados (nacionalização não é socialização), mas a vida íntima do homem já o foi, quase. Nos Estados Unidos como na Rússia, os dois países mais representativos de nossa época e da civilização atual, os reservados públicos são coletivos, isto é, sem separações individuais.",352

Os jornais ilustrados, o cinema, o rádio, a televisão, assim como a história em quadrinhos marcaram o início de uma nova socialidade em que lhes cabia a função de descrever ou registrar os acontecimentos. Tocava então, às artes plásticas, outra função que não mais se ativesse aos conteúdos externos e que cuidasse da vida interior do homem. Em defesa da então arte abstrata, condenada com severidade pelos intelectuais que se limitavam a predicar mens agem social para a arte, Pedrosa dizia em seu artigo que os artistas conscientes sabem "que o papel documentário dela acabou" e que "sua função agora é outra: a de ampliar o campo da linguagem humana na pura percepção". ${ }^{353}$ Essa volta às próprias coisas percebidas, ao olhar do apreciador, permitia um desprendimento de tudo aquilo que se acrescentava de fora à visualidade. $O$ ideológico, a mensagem externa dirigida, etc. eram substituídos pela pura percepção, ao

\footnotetext{
${ }^{351}$ PEDROSA, M. Op. cit., p. 246.

352 Idem, ibidem, pp. 246-247.

${ }^{353}$ Idem, ibidem, p. 247.
} 
mesmo tempo em que se criava a possibilidade de dizer o ainda não dito. Processava-se, por meio da arte, um enriquecimento interno do homem. ${ }^{354}$

Como diria Pedrosa, os artistas modernos prodigalizaram a invenção de novas formas e modelos para as obras, mas seu grande contributo não foi apenas a renovação arrojada das formas no campo da linguagem artística. Sobretudo, eles implementaram uma revolução da sensibilidade que combatia o esvaziamento interior dos homens e a ascensão do pragmatismo burguês. Em oposição ao racionalismo instrumental ou mecânico e o ofício institucionalizado da arte, os artistas abriram o campo da imaginação, em favor de um salto qualitativo da consciência ou de uma nova dimensão espiritual. Nesse desenvolvimento sem precedentes do espírito, antes embotado, residia a contribuição dos artistas para a formação do homem do futuro. Portanto, a arte moderna oferecia a possibilidade de cultivo da individualidade e da imaginação, contra a usurpação e a devassa contínua da interioridade do homem efetuada pela comunicação de massa dirigida.

A imaginação era fundamental para que se percebessem e se compreendessem os efeitos dos avanços espantosos da ciência na vida dos homens. Segundo Pedrosa, tratava-se de elaborar esse novo estágio civilizacional na arte. A tarefa primordial da arte consistia em ser: "um esforço para transcender a visão convencional, isto é, tornar o homem de hoje, e sobretudo o de amanhã, capaz de abarcar pela imaginação, de conceber plasticamente o mundo fabuloso que a técnica e a ciência moderna vão devassando diariamente." 355 Aqui, a metáfora do conhecimento científico na obra era substituída pela concepção ativa da arte, que acompanhasse o significado daqueles avanços e também preparasse o campo para as transformações políticas e sociais. A tarefa primordial da arte era tornar factível que os homens fossem além da mera constatação daquelas transformações do mundo e percebessem todo o significado nelas contido. Esse momento de consciência, provindo da experiência estética, fortalecia e

\footnotetext{
${ }^{354}$ Na publicação do presente artigo, sete anos mais tarde, Pedrosa acrescentou o termo "nos limites do individual". É importante notar: Pedrosa queria dizer com individual, e não individualista, que os artistas não tinham mais grupos ou movimentos de vanguarda para seguir e que a pesquisa plástica e as poéticas estavam cada vez mais centradas no próprio artista. A seguir, o trecho aludido na íntegra: "Os pintores e escultores ditos abstratos (...) Sabem que o papel documentário deles acabou. A missão deles agora é outra: ampliar o campo da linguagem humana na pura percepção, nos limites do individual." Cf. PEDROSA, M. "Arte e revolução" In Política das artes, (organização Otília B. F. Arantes). São Paulo: EDUSP, 1995, p. 98.

355 PEDROSA, M. "Arte e revolução" In Homem, mundo, arte em cris e, (organização Aracy Amaral). São Paulo: Editora Perspectiva, 1985, p. 247.
} 
enriquecia espiritualmente o homem para agir e para enfrentar as imensas dificuldades características de seu tempo.

Somente com a aposta na formação da consciência, em um conhecimento sensível, que se revelasse através do concurso privilegiado da arte, podia-se conceber uma transformação verdadeira da sociedade. Se as forças de transformação do mundo estavam em curso, seu significado positivo dependia do surgimento e também do avanço das condições propícias para formação do indivíduo. A capacidade desalienadora da arte era a chave para a transformação profunda da sociedade. Pedrosa conclui: "A revolução política está a caminho; a revolução social se vai processando de qualquer modo. Nada poderá detê-las. Mas a revolução da sensibilidade, a revolução que irá alcançar o âmago do indivíduo, sua alma, não virá senão quando os homens tiverem novos olhos para olhar o mundo, novos sentidos para compreender suas tremendas transformações e intuição para superá-las. Está será a grande revolução, a mais profunda e permanente, e não serão os políticos, mesmo os atualmente mais radicais, nem os burocratas do Estado que irão realizá-la. Confundir revolução política e revolução artística é, pois, um primarismo bem típico da mentalidade totalitária dominante., 356

Tirante a questão da recepção da obra pelo público, o painel "Tiradentes" de Portinari trazia à tona a necessidade de esclarecer qual é o fundamento da comunicação na arte moderna, o que envolvia tanto as causas atuantes na formação de uma nova sensibilidade como a construção nova do objeto na arte. Longe de transmitir uma mensagem comprometida com a redundância da visão cotidiana, Pedrosa entendia que a função comunicativa da arte exercia-se como modo específico de desalienação e de conhecimento. Assim, a pergunta sobre o significado da mensagem artística dependia, por sua vez, de definir e de situar o novo objeto de comunicação na arte. Isso permitia uma reavaliação crítica e salutar do estabelecimento e reprodução de um padrão perceptivo pautado no banal e no lugar-comum, à medida que indicava a influência do pensamento instrumental em todas as instâncias cognitivas vigentes. Com a superação da exigência gnoseológica de validade de todo conhecimento a partir de sua comprovação prática, evitava-se a construção da visualidade baseada com exclusividade na suposta transposição de dados sensíveis da visão cotidiana para a obra.

\footnotetext{
${ }^{356}$ PEDROSA, M. Op. cit., p. 247.
} 
Ainda que a definição da arte como reprodução da realidade e sua avaliação como atividade menor, pois baseada em impressões subjetivas do artista, parecessem antagônicas, elas eram na verdade o resultado da influência prejudicial de uma concepção científica objetivista e prática. Pelo emprego exclusivo de um método empírico, ${ }^{357}$ essa concepção pretendia oferecer explicação do mundo e foi acompanhada pelo exercício de um empirismo visual na arte naturalista. Em oposição a esse estado de coisas é que se recuperava a especificidade da atividade artística como forma cognitiva ou formação de consciência. Sem negar o lastro objetivo oferecido pelas novas descobertas da ciência, Pedrosa empreendeu uma revisão necessária do processo e da relação de conhecimento. Não se tratava apenas de uma reabilitação da atividade artística no desvelamento do mundo, mas também do afastamento de um racionalismo abstrato, da revisão do empirismo e da inclusão do homem como parte fundamental daquela relação. Aqui, a crítica de Pedrosa dirigia-se à doutrina do positivismo e congêneres, à psicologia objetivista do behaviorismo e ao intelectualismo.

A inauguração de uma visualidade mais complexa do mundo coincidia com os descobrimentos da física de Max Planck sobre a negação do princípio de continuidade uniforme do espaço ou ainda com as formulações de Albert Einstein sobre contração e dilatação do tempo. Nesse ínterim, a fenomenologia de Husserl e a teoria da Gestalt surgem como alternativas viáveis, para dar lastro ao intelectualismo e ao empirismo de base idealista, com a volta corretiva às coisas mesmas. ${ }^{358} \mathrm{Em}$ arte, a frente de combate ao padrão visual consolidado ou à visão cotidiana atingia seu ponto alto com a perscrutação sobre o fundamento da comunicação e, por conseguinte, sobre as mudanças de significado atribuído ao objeto. A definição desse último era necessária para que se pudesse explicar com suficiência as inovações propostas pela arte moderna,

\footnotetext{
${ }^{357}$ Para os empiristas, um estímulo pontual externo atuaria sobre o sujeito e da somatória desses estímulos surgiriam as sensações ou idéias abstratas sobre aquela experiência. Nesse sentido, o conhecimento dependeria de modo predominante do objeto exterior e o pensamento seria sua reflexão passiva. Assim, a formação e associação das idéias derivariam do hábito ou da prática. Para os intelectualistas, que partiam do preceito de que o conhecimento é formado por idéias, o objeto era um mero motivo para manifestação do sujeito ativo. Por isso, o intelectualista considera a idéia como fonte primaz de conhecimento e também compreende que o sujeito reconhece no objeto aquilo que previamente já se encontra como possibilidade em seu pensamento. Como veremos, a Gestalttheorie fez a crítica tanto do objetivismo quanto do subjetivismo por compreender que o conhecimento pressupunha a relação sujeito e objeto. Esses são constituintes um do outro e indissociáveis.

${ }^{358}$ Veja-se a crítica de W. Köhler ao empirismo de David Hume: "Parece-me, porém, que esta grande figura da história do pensamento humano foi apenas o mais eminente representante de uma tendência que também se fez presente na Grécia, há mais de dois mil anos, e que tem sua origem em profunda necessidade de clareza. (...) Acredita-se, em geral, que Hume foi o maior empirista de todos os tempos. No entanto, reduzindo o mundo da experiência a pedaços, entre os quais só prevalecem relações formais, foi ele inteiramente dominado por certas premissas e ideais intelectuais." Cf. KÖHLER, W. Psicologia da Gestalt. Belo Horizonte: Editora Itatiaia, 1968, pp. 192-193.
} 
já que o pressuposto da reprodução da realidade fora posto em dúvida e que se somava a isso os prejuízos recorrentes da concepção demasiada subjetivista ou de primazia do sujeito cognoscente como princípio da produção artística - cuja marca decisiva deveut se à filosofia de Kant.

\section{Crise da representação: percepção renovada e crítica da arte assimilada}

Em momentos diferentes, Mário Pedrosa discutiu o problema do objeto com o intuito de reformular e tornar precisa a relação de conhecimento inscrita na arte. Primeiro, no artigo "Crise do objeto e Kandinsky", publicado na Tribuna da Imprensa em 24-01-1953, depois, na homenagem póstuma a André Breton, intitulada "Crise ou revolução do objeto" e publicada no Correio da Manhã em 21-05-1967. A tônica desses dois artigos foi em suma a mesma, não se encontrando diferença na ancoragem do estudo da arte à luz da teoria da Gestalt, mas na constatação de que o processo histórico tinha negado tanto a justa relação cognitiva entre sujeito e objeto quanto interrompido a realização das promessas incutidas na arte moderna ${ }^{359}$. De um lado, tinha-se o prosseguimento a toda velocidade da tendência construtiva na arte brasileira, de outro, o desenlace do projeto moderno com a constituição de um novo marco divisório para as artes plásticas no Brasil e no mundo, designado por Pedrosa como "pós-moderno", que se instaurava a partir da Pop Art.

Em 1953, Pedrosa retoma a crítica da visão cotidiana e do realismo a fim de esclarecer a concepção de objetividade subjacente à nova atitude de Wassily Kandinsky frente à arte. Essa concepção contrapunha-se tanto ao objetivismo, que pretendia indicar no conhecimento empírico da realidade a fonte da representação fidedigna na arte, como ao subjetivismo, que relegava a existência do mundo ao ponto de vista do sujeito. Essas duas abordagens tinham em comum o afastamento da experiência direta do sujeito com o objeto e, por consequiência, validavam ou a existência da consciência como um dado anterior ou a realidade como um pressuposto teórico. O ponto nevrálgico da crítica ao

\footnotetext{
${ }^{359}$ A partir daqui, seguimos indicações da análise de Otília Arantes sobre os elementos básicos da teoria do conhecimento formulada por Mário Pedrosa. Cf. ARANTES, O. B. F. Mário Pedrosa: Itinerário crítico. São Paulo: Cosac Naify, 2004. pp. 72-100 e pp. 159-169.
} 
behaviorismo, como doutrina psicológica que seguia o modelo empírico, e ao subjetivismo de Kant, que justificava os fundamentos do mundo em categorias a priori do pensamento, referia-se à fundação cognitiva de uma relação sintética entre sujeito e objeto, entre forma e conteúdo. Assim, Kandinsky soube ver a nova função da arte, que se distanciava da reprodução dos dados empíricos e fundava a emoção no espectador a partir do contato indissociável e enriquecedor com o objeto.

Crise do conceito de representação na arte, crise da separação entre conteúdo e forma, e em seu lugar o estabelecimento de uma nova base para o conhecimento a partir da Experiência Primeira, do lugar privilegiado da arte. Mário Pedrosa encontrava no pintor russo a característica definidora da arte em nossa época, a saber, a procura de um sentido perceptivo mais amplo e o afastamento da pintura da função de mero termo designativo do "real imediato". Diz ele: "Wassily Kandinsky foi o primeiro, na corte dos revolucionários modernos, a perceber o que se escondia por trás dos esforços criadores dos impressionistas, de Cézanne, Gauguin, Van Gogh. Com efeito, ele tomava as formas tradicionalmente representativas dos objetos - já reduzidas embora por Cézanne a cones, esferas e prismas - na sua essência despojada de acidentes, isto é, separando-a da objetivação empírica. As formas geométricas são libertadas para novas funções, para novas experiências." ${ }^{, 60}$ Elas indicavam uma tentativa de recuperar, através da experiência estética, o contato relacional do sujeito com o objeto, afastar o processo racionalista abstrato e divisar, pelo conceito de forma, uma síntese entre matéria e pensamento.

Nas obras de Kandinsky, a supressão completa do objeto representado não se traduzia na crítica à noção de objetividade, mas na substituição da pressuposta realidade fixa, definida pela redundância da objetivação empírica. A partir da transformação da referência naturalista em pura abstração, passava-se do entendimento da obra como transposição passiva da realidade imediata para a compreensão do signo plástico em sua constituição específica e concreta. Por isso, o mesmo princípio perceptivo que justificava a experiência direta da realidade no sujeito garantia a objetividade na obra. Dele adviria a função exclusiva da arte moderna de suscitar a emoção no espectador, conforme Pedrosa conclui: "O objeto que vinha sendo pouco a pouco deformado, alterado, reduzido, acaba transformando-se em mera abstração, até que os seus últimos vestígios desaparecem na arte pós-Mondrian. Kandinsky é, contudo, o primeiro que,

\footnotetext{
${ }^{360}$ PEDROSA, M. “Crise do objeto e Kandinsky” In Modernidade cá e lá. (org. Otília B. F. Arantes). São Paulo: EDUSP, 2000, p. 186.
} 
com a sua intuição genial, define a nova atitude, a nova função do artista diante do objeto: 'de não mais perceber no objeto senão o poder de provocar a emoção'. O objeto é o que provoca uma emoção."361

A iniciativa de Pedrosa de expressar com nitidez a direção da emoção, que partia do objeto para o apreciador, pode ser entendida como uma maneira de identificar a característica intrínseca da experiência estética e como uma tentativa de redefinir a função do objeto na arte. À primeira vista, poderia parecer uma obviedade dizer que uma pintura de Cimabue ou uma escultura de Rodin suscita emoção no apreciador que as observa. Entretanto, se essa afirmação designasse o resultado da compreensão intelectiva e analítica da obra pelo apreciador, na qual ele procuraria identificar nela as emoções do artista, suas próprias emoções e desejos, ou ainda referências explicativas de uma realidade captada por estímulos externos, estar-se-ia muito longe de entender o que Pedrosa realmente pensou. Para ele, reforçar o sentido fisionômico da aparência do objeto contrapunha-se à estética centrada na subjetividade ou no objetivismo abstrato, à falsa separação entre conteúdo e forma, e garantia a autonomia da arte pelo entendimento de sua especificidade e pelo afastamento de sua função representativa simples. Além disso, o objeto que provoca uma emoção era também a prerrogativa de que o produto artístico fosse assumido em sua objetividade concreta.

O ensaio sobre Wassily Kandinsky centrava-se nas conclusões a que Pedrosa chegara em sua tese, "Da natureza afetiva da forma na obra de arte", apresentada para o concurso da cátedra de História da Arte e Estética na Faculdade Nacional de Arquitetura, Rio de Janeiro, em fevereiro de 1949. Nela, duas preocupações foram mais evidentes: uma consistia em definir o problema cognitivo envolvido na apreensão do objeto pela percepção, outra em estabelecer e definir o que consiste a especificidade do campo artístico. Essas preocupações revelavam a tentativa de formulação de uma alternativa para a crise da representação na arte e a superação do modelo dualista de conhecimento: realidade e arte, conteúdo e forma. Isso porque, quando Pedrosa formulou a constituição do objeto fenomenológico, tornou-se também possível diferençar o plano perceptivo do plano discursivo, efetuando a crítica da representação e estabelecendo a especificidade da arte. Ademais, sua abordagem sobre os elementos característicos da arte teve o mérito de exceder o campo estrito da estética e instalar-se na investigação dos fundamentos do conhecimento humano sobre a realidade.

${ }^{361}$ Idem, ibidem, p. 186. 
Em oposição ao caráter dissecador e fragmentário do pensamento científico, Mário Pedrosa opta pelo estudo descritivo em lugar da análise do objeto. Para ele, mesmo que se possa distinguir em um momento posterior as atividades ligadas ou não estritamente à prática, todas elas possuem uma origem comum. Todo conhecimento humano deriva da experiência primeira e nela encontra sua unidade. Assim, a pergunta sobre como o homem conhece a realidade é transferida para o questionamento da natureza e das propriedades da percepção. Essa seria como um edifício a partir do qual o mundo se organiza na relação com o homem. Pedrosa afirma que "a primeira aquisição científica, a primeira aquisição filosófica e a primeira aquisição estética estão reunidas de início no nosso poder de perceber as coisas pelos sentidos. O primeiro olhar do homem contém em si, em germe, todo o futuro de sua civilização. (...) Esta é a experiência imediata. Sobre ela o homem construiu os impérios, edificou seus monumentos, organizou a vida, elaborou a ciência, inventou as religiões com seus deuses, criou a arte. (...) Do ápice dessas realizações imensas, o homem tende a esquecer a célula, a base humilde de todas essas conquistas e maravilhas, a percepção." 362

Se as ciências distanciam-se da experiência primeira pela análise dos elementos nela contidos, isso não ocorre com a arte, já que na percepção estão as leis estruturais da visualidade. Como diria Pedrosa, à medida que se afasta do contato direto com o objeto ou da percepção sincrética global, a arte perde muita vez sua pureza ou sua força expressiva e enlea-se a exigências externas, ora analíticas ora significativas. Aqui, efetua-se tanto a constituição da especificidade da experiência estética, no sentimento do objeto dado pela percepção, como a separação gnoseológica entre ciência e arte. Esses aspectos são decisivos para definir o modo peculiar de conhecimento realizado pela arte e para evidenciar a maior autonomia dela, se comparada com a ciência e sobretudo com a técnica, frente às imposições práticas. ${ }^{363}$ Daí parte a compreensão da

\footnotetext{
362 PEDROSA, M. "Da natureza afetiva da forma na obra de arte" In Forma e percepção estética. (org. Otília B. F. Arantes). São Paulo: EDUSP, 1996, p. 107.

${ }^{363}$ É interessante observar que a crítica de W. Köhler ao rigorismo científico do behaviorismo, baseado na utilização do método empírico e da experiência objetiva, levantava o problema do recurso à experiência direta da percepção pelos próprios cientistas. O teórico da Gestalt, discípulo de Husserl e de Wertheimer, mostrava que a noção de método objetivo na ciência não podia prescindir, de mais a mais, da constituição do objeto fenomenológico. Ele diz: "Já mostrei como, mesmo na qualidade de físico, temos de atuar com a experiência direta. Sem dúvida, um extremista tal como o adepto do behaviorismo poderia tirar dessa afirmativa algumas dúvidas quanto ao objetivismo dos métodos seguidos no estudo da física." E diz o behaviorista, "que posso saber sobre a experiência direta de outrem? Jamais terei uma prova definitiva da validade de tal conhecimento. Na Física, porém, a questão é diferente. Ali, estamos a salvo'. O adepto do behaviorismo esquece-se de que provar a existência de um mundo físico independente é quase tão difícil
} 
potencialidade revolucionária da arte e também a orientação crítica contra o pensamento científico compartimentado que desconsidera as propriedades fisionômicas e estruturais dos objetos.

Para Pedrosa, a volta ao objeto ou a reaproximação entre sujeito e objeto era essencial para que se evitasse o empobrecimento da experiência estética e o predomínio de uma relação "vaga e abstrata, puramente conceitual ou utilitária (em que) o objeto deixa de aparecer por si mesmo na sua expressão total." ${ }^{, 364} \mathrm{Na}$ civilização ocidental, essa conjuntura da relação sujeito-objeto levou a uma separação entre o sistema racional e científico e a experiência estética. Por isso, o estudo da percepção revelava-se como uma abordagem primordial do fenômeno artístico e como uma alternativa de transformação profunda e ampliadora das bases do conhecimento, ou ainda na conclusão de Pedrosa: "A experiência estética contemporânea é um convite a sair da bitola do cotidiano. Não por escapismo, por fuga à realidade. Ao contrário, por uma necessidade bem mais decisiva de definir a infra-realidade do homem e em todos os seus refólios e a super-realidade que é, por baixo da rotina imediatista do atual, o que do presente, da atualidade é mais profundo, mais autêntico e mais permanente, por já participar do futuro." 365

A crítica de nossa sociedade utilitarista implicava a ênfase de Mário Pedrosa no aspecto autônomo da arte e, sobretudo, no descondicionamento especial da percepção. Para isso, era preciso não somente reafirmar a percepção como experiência primeira, mas também enfrentar a força de convencimento das teorias que reduziam e apoiavam a capacidade cognitiva humana na prática ou nas necessidades. O pragmatismo era seu exemplo. Segundo essa teoria, de inclinação quer empirista quer subjetivista, a organização perceptiva surgia de um ato do sujeito e era precedida pelo reconhecimento do objeto; identificava-se na percepção o objeto consolidado pelas experiências anteriores, pelo uso, ou que suprisse as necessidades do sujeito. Desse modo, a percepção era vista como atividade secundária e não primordial do homem no contato com mundo. Conquanto Pedrosa admitisse e comprovasse uma "harmonia

quanto nos certificarmos de que outras pessoas têm experiências.” Cf. KÖHLER, W. Psicologia da Gestalt. Belo Horizonte: Editora Itatiaia, 1968, pp. 23-24.

${ }^{364}$ PEDROSA, M. "Da natureza afetiva da forma na obra de arte" In Forma e percepção estética. (org. Otília B. F. Arantes). São Paulo: EDUSP, 1996, p. 173. (parênteses nossos).

${ }^{365}$ PEDROSA, M. "Crise do objeto e Kandinsky" In Modernidade cá e lá. (org. Otília B. F. Arantes). São Paulo: EDUSP, 2000, p. 188. 
suficientemente geral"366 entre percepção e necessidade, isso por si só não validava a anterioridade do ato ou a predisposição do sujeito sobre a organização perceptiva pelo simples fato de tal organização ser o único "testemunho (...) do processo cerebral" e de que "não estando aparente o ato, reduz-se a um suposto esquema (...) inacessível". 367

A organização da percepção segundo a predisposição ou o ato do sujeito presume um objeto passivo e, por isso, a colocação das motivações e experiências subjetivas como base única de todo conhecimento. Antes de tudo, essa concepção foi identificada por Pedrosa no pragmatismo e nos escritos de Eugenio Rignano. Justamente porque o processo psicológico total surge como "um mundo exterior próprio do sujeito, organizado conforme suas necessidades", não se pode identificar seu ponto inicial em um ato do sujeito, mas na concepção gestaltiana da organização perceptiva ou no "efeito da ação que o mundo exterior tende a exercer sobre (o sujeito)". ${ }^{368}$ Comenta Pedrosa: "Contrariamente ao ponto de vista de Rignano, a percepção do todo autônomo não é fruto de reações motrizes e afetivas comuns a vários objetos que nos interessam, que nos são úteis. Não percebemos numa situação apenas o que nos interessa, o que pode satisfazer a uma necessidade. A percepção não se exaure com sua função utilitária, a serviço da adaptação biológica, como pretende Rignano.”369

Para esse teórico da psicologia funcional, a repartição das sensações elementares formando uma unidade em si, um objeto ou uma coisa, "é um fenômeno que não tem mais nada de sensorial: é um fenômeno de natureza afetiva, fato que tem escapado completamente tanto aos associacionistas ingleses quanto aos 'gestaltistas' alemães (...), o que imprime a tal ou tal grupo de elementos sensoriais o caráter de unidade e a 'fisionomia' de um 'objeto' ou de uma 'coisa', é a satisfação ou insatisfação, direta ou indireta, que procure em tal ou tal de nossas tendências afetivas: tal ou tal grupo de elementos sensoriais, - a um fruto, um pedaço de pão, uma fonte, um copo de vinho, satisfaz a fome e a sede; tal ou tal grupo de elementos sensoriais, - uma árvore ou pêlo lanoso de uma ovelha, - protege-nos contra os raios ardentes do sol ou contra as intempéries; (...) ipso facto, cada um desses conjuntos sensoriais torna-se uma unidade,

\footnotetext{
${ }^{366}$ Cf. PEDROSA, M. "Da natureza afetiva da forma na obra de arte” (introdução) In Forma e percepção estética. (org. Otília B. F. Arantes). São Paulo: EDUSP, 1996, pp. 109-111.

${ }^{367}$ Idem, ibidem, p. 110.

368 Cf. PEDROSA, M. Op. cit., p. 110. (parênteses nossos).

${ }^{369}$ Idem, ibidem, pp. 110-111.
} 
um complexo unitário, distinto de todos os outros, e isso precisamente enquanto meio de satisfação ou causa de insatisfação de tal ou tal de nossas tendências afetivas." 370

Há ali uma inversão do significado atribuído pela Gestalt à natureza afetiva do objeto, e mais: Rignano negava a segregação de uma unidade visual, de um objeto, como dado perceptivo, atribuindo-lhe sobretudo caráter significativo. Com isso, o teórico atacava um dos princípios fundamentais subentendido no conceito de forma. $\mathrm{Na}$ constelação de "sensações elementares" não se imprimiria, de acordo com as leis da estrutura (distância, semelhança, boa forma), um caráter de unidade. Comenta Rignano: "Mas suponha-se que existe entre $A, B$ e $C$ uma cimentação mais forte que aquela existente entre esses elementos e $D$, isso não basta para imprimir um caráter de unidade ao grupo $A, B, C$ : a ligação mais sólida entre esses últimos pode nos fazer compreender porque, apenas por sua aparição, $A$ evoca, mnemonicamente, os elementos sensoriais $B$ e $C$ com mais facilidade que o elemento sensorial $D$ fazendo parte da ambiência ou de um outro objeto, mas ele não nos explica por que o grupo $A, B, C$ aparece, psicologicamente, como uma unidade, como um 'objeto",.371

Em contraposição à teoria da Gestalt, o conceito de memória vinha dar base ao efeito de segregação do objeto - isso a partir da idade mais tenra de contato do homem com a constelação de sensações elementares. De acordo com Pedrosa, Rignano partia de uma suposta apreensão empirista do mundo para alcançar uma posição subjetivista sobre o conhecimento: “(às crianças), o mundo não se lhes apresenta confusamente como um caos, um emaranhado difuso de sensações, mas antes como um campo delimitado, sobre o qual se destaca uma figura. Tudo se organiza com essa estrutura,372, ou ainda, "Existem, conforme nos demonstraram as experiências com figuras abstratas feitas por Wertheimer e outros, formas primitivas, primárias. Verificou-se que a dissociação da figura e do fundo e a organização das figuras existem sempre, nada tendo de arbitrário. (...) Desse fato se conclui que a percepção não nasce de um caos ao qual impõe ordem, graças ao auxílio de experiências anteriores. Ela não é resultante, pois, da atividade intelectual. Por isso mesmo foi comparada a leis físicas.”373

Se bem que Rignano admitisse - assim como os membros da escola pragmatista ou psicologia funcional o fizeram - a evidência da reação ao estímulo externo, essa

\footnotetext{
${ }^{370}$ RIGNANO, E. "La Théorie de la Forme" In Problèmes de psychologie et de morale. Paris: Librairie Félix Alcan, 1928, p. 121.

${ }^{371}$ RIGNANO, E. Op. cit., pp. 119-120.

372 PEDROSA, M. "Da natureza afetiva da forma na obra de arte" In Forma e percepção estética. (org. Otília B. F. Arantes). São Paulo: EDUSP, 1996, p. 108. (parênteses nossos).

${ }^{373}$ Idem, ibidem, p. 147.
} 
nada mais era que o reconhecimento, no objeto, de predisposições do sujeito tanto para satisfação de suas necessidades como cultivadas pelo hábito. Em outras palavras, o sujeito reconhecia no objeto somente aquilo que lhe convinha e, a partir disso, dava significado para o processo de conhecimento e para o mundo. Aqui é importante que se abra um parêntese: não há dificuldade em compreender que as consequiências daquele pressuposto teórico não se restringiam apenas à formulação de um modelo de conhecimento. No campo da política, por exemplo, o critério subjetivo indicava a falta de um ponto de vista objetivo para a distinção entre processo social consciente e mera ideologia, tão reclamado por Mário Pedrosa também em sua crítica direcionada ao realismo socialista. Antes de tudo, tratava-se de afirmar a anterioridade do processo perceptivo e assim recuperar a objetividade inscrita nas leis da percepção.

Os argumentos de Wolfgang Köhler embasaram parte da crítica de Pedrosa aos postulados teóricos de Rignano ${ }^{374}$. Conforme já se mencionou, a psicologia funcional afirma, a respeito do problema da organização perceptiva, que as experiências locais estão entrelaçadas com o entorno e que a experiência sensorial é uniforme e contínua, sendo que todos os limites do campo são introduzidos a posteriori por "motivos pragmáticos". 375 Ainda que o teórico da Gestalt acolhesse uma interdependência dos elementos no campo visual, tal e qual se constatava na experiência física de um circuito elétrico, onde "as diferenças de potencial e as densidades da corrente distribuem-se ao longo dos condutores, de tal maneira que é estabelecido e mantido um estado estável ou estacionário. Nenhuma parte dessa distribuição é auto-suficiente; as características do fluxo local dependem inteiramente do fato de terem os processos em seu conjunto assumido a distribuição estável" ${ }^{376}$, não havia por que conceder que aquele campo era experimentado como uniforme e contínuo.

Sustentar a uniformidade contínua do campo visual era avalizar a segregação de objetos como unidades por haver um conjunto homogêneo de sensações, identificadas pelo sujeito, que correspoderiam ao objeto físico. Nesse caso, a memória atuaria de modo a generalizar a experiência sensória e classificar como unidade todo conjunto homogêneo de sensações. Ao contrário, para Köhler, uma das características principais

\footnotetext{
374 Wolfgang Köhler escreveu, em 1928, um ensaio intitulado "Bemerkungen zur Gestalttheorie" (Observações sobre a Teoria da Forma), em que responde todas as críticas de Rignano à Gestalt e recusa as idéias daquele teórico sobre a dependência exclusiva da organização perceptiva com relação às condições de interesse e de necessidade. Mais tarde, Köhler voltou à questão para salientar suas posições na controvérsia com William James. Cf. KÖHLER, W. "Organização sensorial” In Psicologia da Forma. Belo Horizonte: Editora Itatiaia, 1968, pp. 81-101.

${ }^{375}$ Idem, ibidem, p. 81.

${ }^{376}$ Idem, ibidem, p. 81.
} 
da percepção é justamente segregar uma unidade no campo perceptivo e destacá-la do ambiente, sem que para isso se tenha reconhecido previamente o objeto. Como comprova o exemplo da cor verde: para que se possa percebê-la não é necessário, relata Köhler, que haja a confirmação de vários significados adquiridos através do hábito, entre os quais, a cor verde como sinal de trânsito ou como símbolo da esperança. Ele conclui que a significação atribuída pelo sujeito ao objeto é posterior à sua percepção como totalidade: "Exatamente da mesma maneira, afirma a psicologia da Gestalt, as unidades sensoriais adquiriram nomes, tornaram-se ricamente simbólicas e sabe-se agora que elas têm certos usos práticos, embora existissem como unidades, antes que lhes fossem ajuntados quaisquer desses fatos posteriores."377

Wolfgang Köhler arrola vários outros exemplos sobre a formação de unidades no campo visual independente do concurso do aprendizado ou de conhecimentos prévios à experiência perceptiva, tais como: a segregação de nuvens, de estrelas no céu, de conjuntos de manchas no papel. Assim é o caso - citado por Pedrosa - da constelação de Cassiopéia ou da Ursa Maior, em que se considera cada uma delas como unidades separadas do ambiente, sem que seja preciso ensinar qualquer coisa sobre essas constelações para que mesmo crianças as vejam, em uma noite clara, como unidades. Com isso, Köhler contestava tanto a concepção empírica da multiplicidade dos dados sensórios como as leis de operação e associação racional (semelhança, causa e efeito, contigüidade no tempo e no espaço). Esses dois pontos relacionavam-se entre si de maneira que o processo perceptivo - derivado da operação racional - concedia uniformidade e continuidade à multiplicidade dos dados sensórios.

Contra os prejuízos do empirismo atuante na filosofia de Eugenio Rignano ou de William James -, Köhler sustentava que impressões simultâneas não são independentes como num caos, mas constituem uma totalidade segundo leis estruturais. Essas leis não são formadas pela operação racional independente ou sobre a somatória da multiplicidade dos dados sensórios, mas trata-se de relações inerentes à percepção como experiência prévia e fundante do conhecimento. Donde ele concluía: "Quando unidades distintas se reúnem em um grupo, a parte que a igualdade (ou semelhança) representa na unificação não pode ser explicada em função do aprendizado. O mesmo fator, porém, tem uma influência unificadora no caso de áreas contínuas, representem elas ou não objetos conhecidos. Conseqüentemente, é inútil aplicar-se a explicação empírica a essa

${ }^{377}$ Idem, ibidem, p. 83. 
formação de coisas homogêneas contínuas, pois a formação de grupos prova que a igualdade favorece o agrupamento sem nenhuma influência do conhecimento adquirido.",378

Nesse sentido, Mário Pedrosa negou o empobrecimento da experiência perceptiva, com a salvaguarda do processo de conhecimento do objeto diante da ameaça subjetivista, que se implementava através das cavilações teóricas de Rignano e do pragmatismo. Em arte, a experiência perceptiva do objeto traduzia-se na atitude do sujeito, em que "o ato é manifesto no sentido do criador" e "Tudo parte de nós, de nossas emoções e movimentos, sendo a emoção estética uma experiência puramente subjetiva." 379 Contra a equivalência redutora da experiência estética da obra de arte às projeções de sentimentos, proposta pelo expediente de Rignano e inclusive com influências de uma concepção estética pautada na inspiração, Pedrosa defendia a unidade da obra percebida inalterável e independentemente do sentimento do espectador. Se a percepção não se reduzia à satisfação de motivos pragmáticos e também não dependia com exclusividade de um ponto de vista subjetivo ou da associação de idéias, tinha-se a certeza de que a obra de arte constituía um dado objetivo e de que o sentimento baseava-se na forma. ${ }^{380}$

Como diria Pedrosa, a unidade perceptiva da obra de arte traduz-se não na soma de uma multiplicidade de dados sensórios, mas na inter-relação de suas partes de tal modo que nenhuma delas é auto-suficiente e cada um depende do todo. Essa forma ou estrutura, com suas leis internas, não apenas evidencia a objetividade da obra como revela sua autonomia, "sua escala instrínseca de valores, seu poder emocional derivado de seu próprio drama formal". ${ }^{381}$ Respeitado o acordo aproximativo entre percepção sincrética global e obra de arte, não se poderiam encontrar motivos extrínsecos que explicassem sua beleza e também não seria plausível limitar a obra à transposição de significações intelectuais. Isso porque, segundo Pedrosa, o que importa na obra de arte

\footnotetext{
${ }^{378}$ KÖHLER, W. Op. cit., p. 85.

379 PEDROSA, M. "Da natureza afetiva da forma na obra de arte" In Forma e percepção estética. (org. Otília B. F. Arantes). São Paulo: EDUSP, 1996, p. 110.

380 Pedrosa assim discorda da avaliação feita por Rignano do fenômeno da música: "Rignano, ao contrário, quer ver a unidade de uma melodia no sentimento que ela inspira. Ele não explica, porém, como essa unidade é sempre percebida de maneira inalterável, mesmo quando o sentimento do ouvinte já não pode ser mais o que era." Qual o significado da obra ser percebida como unidade? Pergunta Pedrosa e responde que nada mais é que "reconhecer-se, ipso facto, não ser esse mesmo sentimento simples soma de reações afetivas invariavelmente presas a cada parte da melodia (a cada som, intervalo, etc.) (...) Com isso apenas se fez uma transposição muito mais significativa do ponto de vista estético: deram-se aos próprios sentimentos os caracteres da forma.” Cf. Idem, ibidem, p. 111.

381 Idem, ibidem, p. 118.
} 
são suas qualidades formais e a interatividade de suas partes na estrutura do todo e não ser um "instrumento para outros fins". Já que a forma ou estrutura tem suas leis próprias, estas referem-se igualmente à obra como dado objetivo, pois "as regras que governam a organização sensorial se ajustam à estrutura das unidades objetivas, aos agrupamentos objetivos". 382

Ora, se as leis estruturais governam a unidade perceptiva e, por conseguinte, a estrutura da obra de arte, o problema do estabelecimento e da definição da especificidade do campo artístico não se resolve a contento. Depois de criticar o associacionismo de Deonna - que fazia depender "a beleza "da obra de arte em si da fisiologia e da psicologia’",383 -, com a observação de que a beleza não derivava de um segundo momento de reflexão sobre as qualidades formais, e de criticar a posição de Carl Thurston, que mantinha a memória ou o reconhecimento de objetos como ponto chave para a experiência estética e que consagrava em arte "apenas formas já carregadas de significação", ${ }^{384}$ Mário Pedrosa volta sua atenção para um dos grandes desafios da Gestalttheorie, a saber: como seria possível caracterizar a especificidade da obra de arte, levando em conta o conflito instaurado entre ela e a lei estrutural da forma privilegiada. Pela delimitação desse problema, chega-se à conclusão de que não se tratava tãosomente de diferençar a arte dos outros campos (ciência, religião, política), mas de se perguntar se ela seria de direito e de fato necessária.

O teórico da Gestalt K. Koffka foi o primeiro a identificar a semelhança entre a forma privilegiada e a obra de arte. Ele as compara e conclui que a percepção é artística: "Se o pintor a levar em conta (a pesquisa psicológica da Gestalt realizada sobre as leis da visão) verá que o meio pelo qual o sistema nervoso desenvolve seus padrões organizados de processo não é tão diferente do meio pelo qual ele mesmo pinta seus quadros. A percepção tende ao equilíbrio e à simetria. Ou, expresso diversamente: equilíbrio e simetria são características perceptivas do mundo visual que se realizarão

\footnotetext{
${ }^{382}$ Idem, ibidem, p. 118.

383 PEDROSA, M. Op. cit., p. 118. A doutrina associacionista tem sua origem na filosofia inglesa moderna. Pedrosa pondera: "Ao mesmo tempo em que os dados psicológicos se reduziam a sensações e seus atributos, qualidades primárias e secundárias inventadas por Locke, não era possível abordar o objeto dessa maneira global. Por esse motivo jamais o ego e o objeto entraram em relação direta, espontânea, sintética e afetiva". Idem, ibidem, p. 148.

${ }^{384}$ O comentário de Pedrosa sobre Thurston merece ser transcrito: "É a sua teoria expressão das mais paradoxais dessa educação verbal de que padecemos hoje. A impressão que temos das coisas é terciária, e nos vem indiretamente, já manipulada, através da memória e do hábito. Embora deplorasse o fato, tachando-o de infeliz, pois que, embotada a percepção ingênua primeira, o objeto entra na série, na classificação das coisas conhecidas, transformado em conceito vago, sem carne, sem interesse, Thurston faz dele a pedra fundamental de sua estética.” Cf. Idem, ibidem, pp. 142-143.
} 
sempre que as condições externas o permitam. Quando estas não o permitem, o desequilíbrio e a falta de simetria serão experimentados como uma característica dos objetos ou do campo inteiro, juntamente com uma premente instância para melhor equilíbrio.”385 E mesmo Pedrosa já dissera que a percepção não nasce nem da multiplicidade de dados sensórios nem da atividade intelectual, mas que em suas leis próprias de valor tal que podiam ser comparadas a leis físicas, ou ainda, que a obra de arte deve manter-se tão próxima quanto possível da percepção sincrética global.

Referindo-se a Koffka mais uma vez, Pedrosa diz que ele soube separar a realização da obra de arte e a formação da percepção no dia-a-dia, onde "o organismo faz o melhor que pode nas condições dadas e, em geral, essas condições não lhe permitem fazer um bom trabalho". Não se tratava de negar que a arte fosse regida pelas mesmas leis estruturais envolvidas nas percepções mais primárias ou mais complexas dos objetos. Ao contrário, o que ocorre com a arte é uma aproximação efetiva e nas melhores condições com a percepção primeira, sendo sua realização fundamental como "uma espécie de correção individual, consciente, da percepção primeira, no sentido de lhe dar uma estrutura idealmente perfeita (...) (que funciona como) um retificador consciente mas desinteressado da percepção, respeitoso porém de sua autêntica espontaneidade primeira". ${ }^{386}$ Daí provinham sua especificidade ou independência em relação ao conjunto de exigências externas e secundárias e, também sua objetividade, cujo lastro comum com a percepção primeira era atestado pelas leis da estrutura.

Contudo, seria possível admitir a existência independente do objeto de arte sem relação com o sujeito que o percebe? Pedrosa afirmava a existência independente do objeto, mas também que o único acesso a ela se fazia através das propriedades formais e das qualidades intrínsecas que constituem, por exemplo, a existência perceptiva do objeto de arte. Deve-se dizer que as gestalts estavam presentes em todos os campos de conhecimento, não eram exclusividade da experiência estética e, em todas elas, há sempre um sujeito em relação com um objeto. Para responder àquela pergunta, a explicação deve-se deter sobre os aspectos subjetivo e objetivo do conhecimento. Pedrosa definiu a relação entre sujeito e objeto, que contém "graus de objetividade e subjetividade", do seguinte modo: o objeto de arte existe como fenômeno objetivo e,

\footnotetext{
${ }^{385}$ KOFFKA, K. "Problems in psychology of art", Art: Bryn Mawr Symposium, Bryn Mawr Notes and Monographs, IX; B. M. College, Bryn Mawr, Pennsylvania, 1940, p. 261 Apud PEDROSA, M. "Da natureza afetiva da forma na obra de arte" In Forma e percepção estética. (org. Otília B. F. Arantes). São Paulo: EDUSP, 1996, p. 115. Cf. também Idem, ibidem, p. 147.

${ }^{386}$ PEDROSA, M. "Da natureza afetiva da forma na obra de arte" In Forma e percepção estética. (org. Otília B. F. Arantes). São Paulo: EDUSP, 1996, p. 148. (parênteses nossos).
} 
com isso, depende de uma instância que não pertence ao eu, mas aquele se forma apenas e necessariamente a partir do contato com o eu (organismo). ${ }^{387}$

Nesse caso, Pedrosa segue uma explicação similar à de Köhler, quando este afirma que a experiência objetiva depende do eu (organismo): "Mas como posso dizer que uma cadeira, por exemplo, é uma experiência objetiva, se tenho que admitir que ela depende de certos processos de meu organismo? A cadeira não se torna subjetiva sob este aspecto? Torna-se e não se torna. Neste momento mesmo, mudamos a significação dos termos 'subjetivo' e 'objetivo'. No parágrafo anterior, 'objetivo' denotava uma característica que, em contraste com outras, algumas partes da minha experiência possuem em si mesmas (exatamente como êm tamanho, cor, solidez, etc.). Como, porém, tem sido usado até agora, o termo 'subjetivo' refere-se à dependência genética de toda experiência para com meu organismo físico. Neste último sentido, o subjetivismo não é, em si mesmo, um atributo experimentado, mas antes uma relação que atribuímos a todas as experiências e, portanto, também às objetivas, já que aprendemos a considerá-las como resultados de processos orgânicos. Com muita freqüência, são dois significados da expressão confundidos da maneira mais lamentável, como se o que é geneticamente subjetivo também tivesse de aparecer como subjetivo na experiência.",388

Ao contestar a doutrina positivista, que partia da concepção de que o mundo é apreendido pelos sentidos em sua inteireza e chegava à conclusão sobre veracidade do conhecimento pela sua comprovação na prática, Pedrosa propôs a distinção entre o que é e o que aparece. Ela era importante não só para negar o acesso direto pela percepção à essência das coisas do mundo físico, mas para afirmar que o conhecimento do mundo físico - sem que se altere sua objetividade - tem seu ponto inicial na percepção. ${ }^{389}$ Limitando-se, porém, à análise dos dados empíricos fornecidos pela experiência em

\footnotetext{
${ }^{387}$ Idem, ibidem, p. 152.

${ }^{388}$ KÖHLER, W. "Organização sensorial” In Psicologia da Forma. Belo Horizonte: Editora Itatiaia, 1968, pp. $19-20$.

389 Embora admitisse o grau de subjetividade da experiência perceptiva, Köhler ofereceu um exemplo muito ilustrativo da objetividade da percepção. Diz ele: "Quando alguém observa um galvanômetro, observa algo diferente do galvanômetro como objeto físico, pois o objeto de sua observação é o resultado de certos processos orgânicos, dos quais apenas o começo é determinado pelo próprio galvanômetro físico. Com a segunda pessoa, o galvanômetro observado é, também, apenas o resultado físico de tais processos, que, dessa vez, ocorrem no organismo daquela segunda pessoa. De modo algum, portanto, as duas pessoas observam o mesmo instrumento, embora, do ponto de vista físico, ou processos, em um e outro caso, se iniciem com o mesmo objeto físico". E conclui, (se o autor se detivesse aí, reforçar-se-iam as teses da teoria subjetivista): "No entanto, na maioria dos casos, as informações das duas pessoas sobre a observação coincidem a tal ponto que elas jamais se preocupam em saber se pode ser tida como certa uma suficiente semelhança de seus dois galvanômetros experimentados e de ambos com o objeto físico." Idem, ibidem, p. 22.
} 
supostas condições objetivas, a psicologia comportamental negava a objetividade da percepção e centrava-se no estudo das reações fisiológicas, por considerar que a percepção dependia do sujeito, o qual, por isso, carecia de um ponto de vista seguro. Por seu turno, Pedrosa diria que sem a percepção nem conhecimento nem objetividade seriam possíveis, pois é "através dela (...) que um objeto físico pode produzir, ao contato com o nosso ego, um objeto fenomenal. As aquisições da Gestalt nesse campo respondem pelo caráter senão positivo ao menos relativamente objetivo das relações formais no objeto de arte." 390

Pedrosa se refere ao objeto e ao sujeito por meio da relação cognitiva sujeitoobjeto: “As coisas que são subjetivas na primeira definição também o são na segunda: uma dor, nossa ou de outrem, é sempre subjetiva por depender quer do próprio ego quer de outro organismo. Uma cor, porém, entra no objetivo da definição primeira (não depende de nosso ego para existir). Faz parte, entretanto, do subjetivo da segunda definição, pois quando um organismo dela tome conhecimento vai ficar na dependência do sistema nervoso desse organismo. Em compensação, uma mesa entra na coluna do objetivo da primeira definição; entra na coluna do subjetivo da segunda definição e também na coluna do objetivo dessa mesma definição. Substitua-se a entidade mesa por uma obra de arte. Que acontece? Segundo a primeira definição (dependência ou não do eu) ela é fenomenologicamente objetiva. Mas de acordo com a segunda definição, é funcionalmente subjetiva."391

A experiência estética não se organizava com a preponderância do sujeito sobre o objeto, mas que o caráter objetivo da arte não impedia a possibilidade de apreciações diferentes da obra. Aquela objetividade relativa da obra vinha atestar que o objeto fenomênico dependia do "organismo individual" e não que "o valor dado ou atribuído ao mesmo objeto depende da pessoa." ${ }^{, 392}$ Em outras palavras, Pedrosa definia a obra de arte como "fenomenologicamente objetiva" - isto é, que dependia da relação entre objeto e sujeito para se constituir - e como "funcionalmente subjetiva" 393 - o que indicava a apreensão variável, dependente do organismo, mas não totalmente subjetiva da obra. Além desses dois aspectos, atuava, na relação entre obra de arte e apreciador, a categoria do "funcionalmente objetivo", que indicava a possibilidade mesma de se

\footnotetext{
${ }^{390}$ PEDROSA, M. Op. cit., pp. 152-153.

${ }^{391}$ Idem, ibidem, p. 152.

392 Idem, ibidem, p. 153.

${ }^{393}$ Da relação sujeito-objeto derivam duas funções: uma que diz respeito ao objeto em relação ao sujeito (funcionalmente subjetiva) e outra que diz respeito ao sujeito em relação ao objeto (funcionalmente objetiva).
} 
estabelecer o objeto fenomênico e que é a existência física do objeto. Assim, a constituição suprema da relação sujeito-objeto seria a forma ou a estrutura dada pela percepção, que não deve ser confundida com o conhecimento do objeto através de uma idéia resultante da atividade intelectual do sujeito.

Nesse caso, uma das funções mais importantes do objeto de arte seria justamente não permitir que o apreciador desviasse sua atenção da "percepção formal primitiva" em favor de idéias ou de valores culturais estabelecidos, porque ela já era dotada de um sentido intrínseco que não surgia das projeções ou da interiorização do eu. Esse sentido eram as propriedades formais constituintes do objeto de arte. Donde Pedrosa diz: "Se recorro a associações, recordações com base nas minhas lembranças individuais, posso enriquecer a compreensão (do objeto de arte). Mas trata-se aqui de meras adições que juntamos às propriedades formais, que se bastam a si mesmas." ${ }^{394}$ Não é possível separar o fenômeno perceptivo do afetivo e, assim, o sentido intrínseco das propriedades formais do objeto de arte - que não se produz pelo afastamento reflexionante do sujeito em relação ao objeto - surge da experiência perceptiva que é indissociável da significação.

No que concerne à apreciação da obra, Pedrosa opunha-se ao prestígio da teoria da catarsis. Aristóteles definira como uma das funções por excelência da arte, purificar os sentimentos do espectador. Assim, caberia à arte produzir um espelhamento da vida do homem e incidir sobre suas paixões com o intuito terapêutico de expurgá-las. Para Pedrosa, a relação que essa teoria estabelecia entre o objeto de arte e o espectador não podia ser separada da função de "servir o ego em alguma coisa". ${ }^{395}$ Destarte, a teoria da catarsis reduzia a experiência estética, tomava a função da purificação das paixões como definição da essência da arte e não ultrapassava a compreensão da emoção em seu aspecto funcionalmente subjetivo. Em suma, privilegiava-se o lado subjetivo da experiência estética e não se procurava definir o efeito emocional do objeto de arte no espectador em que se deve subsumir o aspecto fenomenológico da relação sujeitoobjeto. Pedrosa falava em favor da dimensão objetiva da emoção: “O ego entra em emotividade ao contato com o objeto; suas emoções são despertadas e se referem a certos aspectos peculiares à coisa, sendo tais aspectos em si mesmos, por si mesmos, emocionantes." 396

\footnotetext{
${ }^{394}$ PEDROSA, M. Op. cit., p. 163. (parênteses nossos).

395 Idem, ibidem, p. 155.

${ }^{396}$ Idem, ibidem, p. 157.
} 
A emoção é definida como o "resultado inteligente" da reação do apreciador às propriedades intrínsecas do objeto. Isso porque, se a manifestação fenomênica do objeto - em conformidade com as leis da percepção - depende do organismo, também o organismo é obrigado a entrar em atividade por causa da presença física da obra. Continua Pedrosa: "Toda sorte de seres, objetos, situações, tem sua fisionomia moral; nenhuma dessas categorias se apresenta como idéia desencarnada. Mas a tese associacionista da transferência, da representação de tudo por sinais quaisquer, isolados, abstratos como os sinais da linguagem falada, não considera, não toma conhecimento dessas peculiaridades intrínsecas, fisionomicamente expressivas de cada ser, de cada objeto, de cada situação. A essa disponibilidade de elementos irredutíveis, como soldados rasos prontos a se unirem em formações quaisquer, indiferentemente, conforme a ocasião ou o comando do chefe, a Gestalt opõe a irredutibilidade expressiva de cada conjunto, ser, coisa, situação, e a impossibilidade de se dissociarem os elementos componentes para examiná-los. À parte eles não existem.”397

A característica fisionômica define-se por conter propriedades significativas e expressivas inerentes, de tal modo que os objetos "em virtude de sua própria estrutura, independentemente de toda experiência anterior do sujeito que os percebe, (têm) um caráter próprio, as qualidades do insólito, do estranho, do assustador, do irritante ou do plácido, do gracioso, do elegante, do áspero, do mavioso, do repulsivo, do atraente etc."398 Para Pedrosa, as qualidades fisionômicas não tinham origem subjetiva, mas constituíam a dimensão objetiva da experiência perceptiva. Essas qualidades, apresentadas na estrutura do objeto, sustentavam a unidade entre conhecimento e mundo, ou se se quiser, entre forma e conteúdo. Não era o caso de separar a atividade cognoscitiva do sujeito e a experiência perceptiva fenomênica, mas de entender a integração imprescindível delas para a formação de um modo de conhecimento inédito. Esse conhecimento pode ser descrito como o acesso direto ao objeto, sem que para isso fosse necessário - no caso do empirista - a ordenação de um conjunto de estímulos prévios feita pela atividade mental, ou ainda, que - no caso do intelectualista - a percepção, por não corresponder à realidade, fosse compreendida como causa de enganos produzidos em nosso pensamento.

\footnotetext{
${ }^{396}$ Idem, ibidem, p. 157.

397 PEDROSA, M. Op. cit., p. 163.

398 Idem, ibidem, pp. 163-164. (parênteses nossos). Cf. também o ensaio do mesmo autor: "Forma e Personalidade" In Forma e percepção estética. (org. Otília B. F. Arantes). São Paulo: EDUSP, 1996, pp. 179-220. Aqui, Pedrosa detém-se melhor na explicação do caráter fisionômico dos fenômenos, denominando-o como o lugar onde se manifesta primeiro a assim chamada "intuição contemplativa".
} 
Em se tratando da relação particular entre obra de arte e apreciador, Pedrosa elencava quais seriam os contatos possíveis do sujeito com o objeto. Isso era de máxima importância não só para comprovar as condições favoráveis à apreciação do objeto de arte, mas também para revelar os prejuízos causados por uma concepção de conhecimento, e inclusive por um modo de vida, que negavam a amplitude das experiências estética e cognitiva. Assim, a relação entre o objeto de arte e o apreciador introduzia, sob crítica incisiva, o problema da constituição da experiência estética no âmbito do próprio conhecimento. Se, por um lado, as grandes conquistas das ciências deveram-se à própria história da formação do conhecimento ocidental que, desde seu início, separou conhecimento racional do mundo e experiência estética, por outro, perdia-se o sentido de unidade entre homem e mundo, reduzia-se de maneira irremediável as experiências vividas pelo homem e sobretudo sua capacidade de conhecimento.

Mário Pedrosa diria que podiam ser três as atitudes do apreciador em relação com a obra, ou do sujeito com o objeto: uma aproximação com o objeto de tal forma que suas propriedades intrínsecas sejam preservadas; um afastamento do objeto e de suas propriedades, devido à influência de interesses de outra ordem; uma aproximação entre sujeito e objeto, na qual tanto as propriedades intrínsecas do último são preservadas, como também o sujeito reage emocionalmente àquelas propriedades. Apoiado no exemplo de Koffka - que compara entre si as atitudes de um engenheiro, de um especulador e de um amante da natureza ou de um pai -, Pedrosa diz: "o especulador e o engenheiro, se encontram em oposição ao objeto de sua observação. Há aqui uma polaridade entre um objeto bem definido e um ego bem definido, com a diferença de ser no engenheiro o objeto a parte dominante do campo, ao passo que no especulador o ego é que o é. A situação do engenheiro que vê o filho cair no mar e do amante da natureza que contempla embevecido a floresta é, por seu lado, diferente da dos outros. Aqui os egos estão muito mais em contato com o objeto." 399

A volta ao objeto com suas qualidades estruturais e fisionômicas ou a defesa da experiência em que ele e sujeito não se opõem eram pontos fundamentais para uma crítica consistente à nossa civilização prática e utilitarista. Cabia então à arte proporcionar uma revolução estética no homem moderno. Nesse sentido, era preciso que a arte contribuísse acima de tudo com o realce de suas qualidades inerentes. Ao

\footnotetext{
${ }^{399}$ PEDROSA, M. "Da natureza afetiva da forma na obra de arte" In Forma e percepção estética. (org. Otília B. F. Arantes). São Paulo: EDUSP, 1996, p. 173.
} 
invés da diferenciação alta do campo com o "isolamento do ego" "400, a arte deveria valorizar a experiência direta da percepção e o caráter fisionômico dos objetos. Conclui Pedrosa: "Na crescente separação do homem ocidental com o campo, o homem nem olha nem entra em relação com o objeto. Os caracteres estruturais das coisas se perdem nessa relação, e o homem se empobrece de todo um mundo profundo de relações e conhecimentos. Na apreciação da obra de arte, a relação do espectador com a obra não é a do campo altamente diferenciado, como a do camponês de (Étienne) Souriau e a do engenheiro com o seu registro, ou a do especulador de madeira. Ambos estão numa relação direta e estreita." ${ }^{401}$

Essa revolução vinha sendo processada pela arte moderna à medida que se deixava de representar a imagem de um objeto exterior e que se passava a entender a própria obra como uma estrutura intrínseca e condizente com as leis da percepção. Foi justamente isso que levou Pedrosa a afirmar mais uma vez, em seu ensaio "Crise ou revolução do objeto" de 1967, que "toda a 'arte moderna', desde seus primórdios, veio se destacando como um processo de destruição sistemática do naturalismo, reinante na estética do século XIX, em seguida ao neoclássico. Como numa etapa lógica a essa primeira destruição se seguiu outra, que foi a do objetivismo. O objeto passa, mesmo a partir do cubismo, do fauvismo, e naturalmente do expressionismo, a ser dissecado, desestruturado e dissolvido. O "modelo exterior" é afinal substituído por outro modelo (...)." ${ }^{\Perp 402}$ Aqui, Pedrosa comentava como a revolução interna da arte moderna postava-se ao lado das promessas de estabelecimento de uma relação "direta e estreita" entre sujeito e objeto.

Se no ensaio sobre Wassili Kandinsky de 1953, Pedrosa criticava a proposta de André Breton de substituir a noção de modelo exterior pela de interior, por necessidade estratégica de indicar que a produção artística deveria ser fundada em uma nova relação entre sujeito e objeto, ${ }^{403}$ no ensaio de 1967 , "Crise ou revolução do objeto", a ênfase foi posta sobre o objetivo comum - que os unia - de crítica à civilização burguesa

\footnotetext{
${ }^{400}$ Cf. Idem, ibidem, p. 174.

401 PEDROSA, M. Op. cit., p. 175. (parênteses nossos).

402 PEDROSA, M. "Cris e ou revolução do objeto" In Forma e percepção estética. (org. Otília B. F. Arantes). São Paulo: EDUSP, 1996, pp. 341-342.

403 Assevera Pedrosa: "O modelo exterior desaparecia para o artista, ficando apenas o que Breton ainda chamou impropriamente de "modelo interior". E este tanto poderia ser uma imagem do mundo do sonho ou do inconsciente - para os poetas do subjetivismo surrealista ou para os visionários fantasistas a Henri Rousseau - como, com muito mais rigor, uma noção nova resultante da ciência moderna ou uma idéia, uma concepção fundada no pensamento matemático, a Max Bill." PEDROSA, M. "Crise do objeto e Kandinsky” In Modernidade cá e lá. São Paulo: EDUSP, 2000, p. 188.
} 
utilitarista. Isso não quer dizer que Pedrosa abandonara sua preocupação com a estética da estrutura, mas que as divergências com a concepção de modelo interior proposta por Breton foram ajustadas em um ensaio intitulado "Forma" de 1951. ${ }^{404}$ Nele, Pedrosa ressalta a mudança na trajetória do poeta e intelectual francês, que logo após a morte de Trotski, por ocasião de sua passagem pelos Estados Unidos em 1941, toma contato com a teoria da Gestalt. Assim, encontravam-se as condições necessárias para o escrutínio das atividades artísticas baseadas no modelo interior, com o primado do inconsciente, dos delírios ou dos sonhos, e representadas principalmente pela estética surrealista. ${ }^{405}$

A maior objeção possível de ser feita à teoria da Gestalt vinha precisamente da arte produzida pelo modelo interior. Não seria ela a contraprova definitiva das pretensões de se fundar sempre a arte na estrutura perceptiva? Porém, Pedrosa dizia que para além da crítica justa de Breton à visão cotidiana, mesmo a arte assentada apenas no mundo onírico não escapava às leis da estrutura, "que é o modo pelo qual a realidade cobra os seus direitos e se manifesta". ${ }^{406}$ Ainda que o material da arte seja o inconsciente, ele só pode se manifestar como arte pela estrutura. E essa última é manifestação da realidade. Decorre disso que não haveria uma divisão possível entre as duas faces da medalha da experiência perceptiva (corpo e espírito) e, da parte do artista, mesmo o emprego do automatismo psíquico, que se concentrava nas propriedades sensíveis e interiores, obedecia às leis de organização da forma na materialização da obra de arte. Assim, o único modo possível de concretização dos produtos do inconsciente é através da forma ${ }^{407}$.

\footnotetext{
${ }^{404}$ Esse ensaio foi republicado com o título "Forma e personalidade" In Forma e percepção estética. São Paulo: EDUSP, 1996, pp. 179-220.

405 Pedrosa cita a ponderação de Breton sobre a tentativa de uma síntese entre o automatismo psíquico e a concepção de forma via Gestalt: "Sustento que o automatismo gráfico, tal como o verbal, sem prejuízo das tensões individuais profundas que ele tem o mérito de manifestar e mesmo, dentro de certos limites, de resolver, é o único modo de expressão que satisfaz plenamente a vista ou o ouvido, realizando a unidade rítmica (tão apreciável no desenho e no texto automático quanto na melodia), única estrutura que responde à não-distinção, cada vez mais aceita, das qualidades sensíveis e das qualidades formais, como a não-distinção, também cada vez mais aceita, das funções sensíveis e das funções intelectuais ( e é por isso que o automatismo é a única coisa que satisfaz igualmente ao espírito)". PEDROSA, M. "Forma e personalidade" In Forma e percepção estética. São Paulo: EDUSP, 1996, p. 186.

${ }^{406}$ Idem, ibidem, p. 185.

${ }^{407}$ A forma nasceria de sua relação com a matéria e sem a qual não poderia existir. Veja-se o comentário de J. Hersch, citado por Pedrosa: "A arte manifesta o que é obscuro sob uma forma clara. É que ela tem de adquirir corpo, estrutura, contorno. A realidade material, que acarreta o compromisso com as necessidades não estéticas de exclusivismo espacial, de gravidade, de todas as causalidades físicas,
} 
Segundo Pedrosa, havia, por assim dizer, uma indissociabilidade entre sujeito e objeto de tal modo que não era possível distinguir as qualidades sensíveis das qualidades formais na percepção. Por isso, "é indiferente quebrar-se a cabeça para saber se se trata de uma realidade formal ou de um formalismo real. Essa exigência formal está presente mesmo num Van Gogh, alucinado e visionário", 408 e continua Pedrosa, “A querela do realismo e não-realismo é assim superada, pois ninguém escapa à realidade, muito menos a alma sonora e sensível do artista, nem a realidade tem outro meio de se manifestar senão através da forma. Quanto às intermináveis discussões e admoestações sobre a necessidade de o artista ser de seu tempo, refletir as lutas do povo, etc., são banalidades que se travam fora do domínio artístico, do mesmo modo que o chamado realismo social, novo lugar-comum para o naturalismo acadêmico da mais baixa espécie. Nada disso é sequer digno de consideração; o conceito de realidade tem hoje outra profundeza, desde a revolução na psicologia trazida pela obra de Freud e os teóricos da estrut ura." $" 409$

A importância dada por André Breton ao modelo interior vinha da intenção de transformar a visão assentada do mundo e de oferecer a possibilidade de cultivo de novas experiências sensíveis. Por isso, o objeto que surgia da dissolução do objeto naturalista negava os esquemas visuais viciados e reclamava o contato com novas formas de espaço e de tempo provenientes do grande avanço técnico e científico de nossa civilização. Se Breton procurava subverter e enriquecer o cotidiano pela introdução de toda a dimensão do inconsciente, rompendo as velhas peias sociais com a reivindicação de tudo aquilo que fora reprimido e que se tornava indispensável à realização plena do homem, sua posição assemelhava-se àquela de Pedrosa, embora a abordagem deles fosse diversa. No caso de Pedrosa, o que importava era justamente reafirmar a estrutura essencial da realidade dada pela percepção e através da qual se estabelece um vínculo mais sutil do homem com seu inconsciente. Assim, a forma artística produzida pelo artista nada mais é que fruto da tensão que se instaura entre os princípios organizadores da forma e seu dado material, quer ele provenha do inconsciente, quer do objeto, tal e qual se encontra fora de nós em sua presença física.

Como Pedrosa teve oportunidade de frisar várias vezes, o surrealismo de Breton não pregava uma fuga da realidade ou uma mistificação sobrenatural a respeito do

psicológicas e sociais, é a prova existencial da arte. Essa realidade é ao mesmo tempo obstáculo à sua existência e à sua condição." Cf. PEDROSA, M. Op. cit., p. 186.

${ }^{408}$ Idem, ibidem, p. 185.

${ }^{409}$ PEDROSA, M. Op. cit., p. 186. 
sonho e, por conseguinte, a desistência ou o conformismo pessimista com a vida. $\mathrm{Na}$ verdade, o sonho era o outro lado da medalha perceptiva, cuja base se encontrava na estrutura da realidade. Esta unia o sonho e a vigília, mostrava como a percepção do são e do louco tem sua origem numa mesma e única realidade. Se o modelo interior de Breton dava prioridade ao inconsciente, ao passo que Pedrosa fundaria o produto artístico na estrutura perceptiva objetiva, o mérito de ambos foi o combate intransigente contra a anulação estética, ética e social do homem moderno. Para além da discordância sobre os alicerces do modelo de criação artística, Pedrosa assinalava a importância histórica e crítica dos surrealistas: “(eles) não admitiam que após a grande revolução iniciada e esperada na Europa, ou no mundo, a vida privada continuasse nas frustrações, que eram o seu cotidiano viver na sociedade capitalista não-transformada. ${ }^{, 410}$

Já no ensaio de 1967 o clima era outro. Mário Pedrosa tentava mostrar como a concepção de objetividade dada pela Gestalt não só definiu uma tendência artística clara de combate ao naturalismo como também ressumava uma nova manifestação de vida e um outro desígnio de sociedade. Era inevitável que se estabelecesse um confronto demarcador das diferenças entre a noção de objetividade que perpassava a arte moderna e aquela contida na Pop Art. Não era para menos, saía-se da voga tachista no cenário internacional das artes - na qual as manchas de cores traduziam-se na atitude apologética da ausência de forma e no meio plástico para a auto-expressividade do artista - com a procura irascível da realidade, da objetividade dada pelo mundo da produção em massa. Não havia por que confundir a imagética surrealista com aquela estabelecida agora pelos artistas pop. Pedrosa compara os dois movimentos: "Essa atitude revista sob o ângulo de hoje, o que se salienta dela é a barreira (tão precária) que em nome do sonho e da poesia o surrealismo tentava erguer à invenção da produção em massa. Trinta anos depois, o que vemos? A pop'art que, ao invés de levantar-lhe uma barreira, capitula perante ela." ${ }^{411}$

Nos anos cinqüenta, Mário Pedrosa demonstrava entusiasmo na defesa da autonomia da arte como possibilidade, nela inscrita, de transformação profunda da sensibilidade e da consciência do homem moderno. A representação convencional do mundo era preterida pela "concreticidade real" da obra de arte moderna. Em tom de depoimento sobre sua atuação como crítico, Pedrosa comenta: “Adotando então - como

\footnotetext{
${ }^{410}$ Cf. PEDROSA, M. "Surrealismo ontem, super-realidade hoje” In Modernidade cá e lá. (org. Otília B. F. Arantes). São Paulo: EDUSP, 2000, p. 256.

${ }^{411}$ PEDROSA, M. "Crise ou revolução do objeto" In Forma e percepção estética. (org. Otília B. F. Arantes). São Paulo: EDUSP, 1996, p. 344.
} 
se era ingênuo logo após a Segunda Grande Guerra - ponto de vista de mero crítico de arte, clamávamos porque nossos artistas visuais ainda não se haviam acomodado ao movimento cinético e à visão multiangular do cinema e do avião. (...) E mostrávamos como na criança e nos povos primitivos, a luta que se estabelece no processo de seu crescimento interior, físico-sensorial-intelectual, para predominância entre o meio de representação visual e o meio de representação verbal, acaba sempre pela vitória do último. Mas prognosticava, a Arte Moderna veio no fundo para lutar a favor do visual." 412 Porém, com a ascendência das formas de controle técnico-social e com o desenvolvimento de estratégias de informação vinculados a interesses políticos e econômicos imediatos, a consciência e a sensibilidade dependiam cada vez mais dos influxos da prática social estabelecida.

Lances finais: se a arte moderna tentou levantar barreiras e trincheiras contra a sociedade capitalista no Ocidente, o combate fora vencido de um só golpe pela lógica da cultura no capitalismo. A comunicação de massa e a sociedade de consumo redimensionaram não apenas o padrão visual coletivo, mas também o âmago dos homens e suas escolhas. Tudo passava a ser determinado por fora e os artistas pop singravam nesse rumo preestabelecido. Assim, o caráter intrínseco da obra de arte e a aposta de Pedrosa na substituição do discurso verbal pela comunicação visual sob os auspícios da percepção eram superados com o desenvolvimento técnico dos meios de informação visual. Pedrosa conclui: “o que (distingue a informação visual) é que tende, em lugar de refletir passivamente as relações fundamentais do homem e do seu meio, a sobredeterminá-las de um modo decisivo, complexa e massivamente. Tanto o cinema como a televisão e a imaginária difusa do conjunto dos meios de informação e expressão modernos distribuem às massas cada vez mais compactas materiais de informação que não são em sua maioria, e não forçosamente, nem extraídos de seu meio imediato ou próximo, nem de nada que a ele se relacione, à primeira vista. 'Tudo se passa como se a evolução da informação do verbal ao visual tivesse desarraigado a representação do mundo e a tivesse, pelo menos parcialmente, libertado dos laços que a prendiam outrora ao meio natural e social.' A observação é poderosa. A avalancha da informação submerge a todos, elite e massa." ${ }^{413}$

\footnotetext{
412 PEDROSA, M. “A passagem do verbal ao visual” In Homem, mundo, arte em crise. São Paulo: Editora perspectiva, 1986, p. 148.

413 Idem, ibidem, p. 149.
} 
Conclusão 


\section{$\underline{\text { Conclusão }}$}

Mário Pedrosa, ao avaliar a situação mundial no início da década de trinta, indicou a arte proletária como direção a ser seguida naquele momento. Dessa forma, o ensaio crítico sobre Käthe Kollwitz apostará numa determinante extrínseca da arte para elaboração e direcionamento de sua temática: "a arte não goza de imunidades especiais contra as taras da sociedade, nem no seu pórtico param, sem transpô-lo, os prejuízos e as contingências mesquinhas ou trágicas do egoísmo de classe. Como outra qualquer manifestação social, ela é corroída interiormente pelo determinismo histórico da luta entre os diversos grupos sociais." ${ }^{414}$ Essa tentativa de vincular a arte à luta de classes explica-se, em parte, pela tomada de posição, no plano local, contra o integralismo e, no plano mundial, contra a ascensão do nazismo na Alemanha. Não menos do que isso, Pedrosa defende as obras de Kollwitz na tentativa de evidenciar o empenho da arte em ampliar sua matéria social, em dar voz ao proletariado e participar da revolução social. Assim, não se tratava apenas de marcar posição como crítico em nosso meio frente ao verdadeiro desígnio da arte moderna, mas de inserir aquela produção artística no contexto em que ela havia sido feita e de apresentar as alternativas por ela apontadas. Nesse sentido, arte e política convergiam.

Porém, essa postura de análise da função da arte não perdurou e Pedrosa fez ajustes necessários em sua avaliação sobre o momento político e social vivido. A nova compreensão de Pedrosa sobre a relação entre arte e sociedade tinha um precedente fundamental: a intromissão das doutrinas política na arte, com a estabilização dos parâmetros criativos e a conseqüente derrocada da arte em instrumento político. Dessa forma, Pedrosa distanciou-se da ênfase no conteúdo da obra para combater a doutrina artística oficial dos PCs e o uso político que se fazia da arte em países como a Alemanha nazista e os Estados Unidos. O Crítico se afastou da defesa de uma arte proletária e aproximou-se da análise estritamente formal do objeto artístico, onde prevalece na obra sua fatura, sua estrutura de relações imanentes e a falta de compromisso com os padrões pictóricos do retrato burguês. Nesse momento, Pedrosa iria participar com fervor das discussões sobre a entrada e consolidação do

\footnotetext{
${ }^{414}$ PEDROSA, M. "As tendências sociais da arte e Käthe Kollwitz" In Política das Artes (Org. Otília Beatriz Fiori Arantes). São Paulo: EDUSP, 1995, p. 36.
} 
abstracionismo no Brasil e acertar contas com a tradição moderna representada por Cândido Portinari.

Esse empreendimento de Pedrosa culminou com a defesa de sua tese - sobre os conhecimentos da Gestalt aplicados ao estudo dos objetos artísticos - no concurso para a cátedra de História da Arte e Estética da Faculdade de Arquitetura da Universidade do Brasil. Apregoando uma síntese integral das artes, Pedrosa acreditava na formação de uma nova sociedade, onde a técnica não serviria a impulsos aniquiladores mas certamente para a emancipação do homem: "A simultaneidade e a generalização do movimento chamado de arte moderna, por toda a parte e através de todas as diferenciações episódicas ou parciais, mostram seu caráter social verdadeiro. Não foi capricho individual de ninguém nem movimento superficial de moda. Foi um momento na evolução histórica da estética e uma imposição das forças produtivas e culturais da época, exigindo manifestar-se sob uma forma social mais nobre." ${ }^{415}$.

A luta de Pedrosa pela difusão da arte de tendênc ia construtiva no meio artístico brasileiro, cuja proposta baseava-se tanto nas inovações formais quanto no compromisso de renovação social do País, estimulou muitos artistas e críticos brasileiros. A arte parecia apontar para um caminho suscetível de ser seguido por outros campos de atividade humana, em uma verdadeira antecipação da utopia social realizada. Nas palavras de Moholy-Nagy: "Felizmente, é uma qualidade inesperada do movimento de arte moderna o fato de que algumas de suas facetas possuam relações ocultas com a vida prática. (Com efeito, pode-se dizer que todo o esforço criador de hoje é parte de um programa de preparação indireta e gigantesca para remodelar, através da visão em movimento, os modos de percepção e de sentir, para conduzir a novas maneiras de viver)." ${ }^{416}$. E, no final dos anos de 1940, Pedrosa dizia: “(...) o ideal é naturalmente, suceda o que suceder, tanto no domínio da pura técnica de construção como no da economia e da política, que se chegue à síntese de que fala Le Corbusier, das três artes maiores - a arquitetura, a escultura e a pintura. $\mathrm{O}$ fato de Le Corbusier aspirar a essa síntese e de nós dois, tanto Agnes Claudius como eu, alimentarmos essa mesma aspiração, não significa que seja ela hoje mesmo uma realidade. Infelizmente, ainda estamos profundamente longe disso." ${ }^{417}$.

\footnotetext{
415 PEDROSA, M. "Panorama da pintura moderna", 1951, In Modernidade cá e lá. São Paulo: EDUSP, 2000, p. 148.

${ }^{416}$ Idem, ibidem, p. 175.

${ }^{417}$ PEDROSA, M. "Ainda a propósito do destino da pintura" In Política das artes. São Paulo: EDUSP, 1995, p. 61.
} 
Tanto o rumo político e social seguido pela URSS como o capitalismo no Ocidente, cujo centro encontrava-se nos Estados Unidos, solapavam a convergência imediata entre produção artística novíssima e dimensão social. A defesa incondicional, feita por Pedrosa, da tendência construtiva nas artes tinha por seu turno uma visada social e política muito específica, ou melhor, havia uma confluência entre o programa artístico moderno e as diretrizes políticas assentadas nos valores democráticos e socialistas. Inicia-se a construção de Brasília em fins da década de 1950. Com vistas a promover no plano internacional a tendência construtiva da arte, coroada pela construção da nova capital, Pedrosa organizou o congresso da AICA ro Brasil. Em 1959, realizou-se em Brasília o Congresso com o tema: “A Cidade Nova, síntese das artes?", onde Pedrosa como presidente, na sessão inaugural, falou emocionado sobre o verdadeiro desígnio da tendência construtiva na arte: "Vejo, em nosso encontro, um símbolo. Nele reluz uma significação extraordinária. Sugere, ou antes, afirma, e veementemente, que o futuro tecnológico, econômico e social deste país não mais se construirá à revelia do coração e da inteligência, como tantas vezes ocorreu no passado e ainda sucede no presente, mas erguer-se-á sob o signo da arte, signo sob que Brasília nasceu. $" 418$.

\footnotetext{
${ }^{418}$ MORAIS, F. Artes Plásticas - a crise da hora atual. Rio de Janeiro: Ed. Paz e Terra, 1975, p. 80.
} 
Bibliografia 


\section{ARTIGOS, ENSAIOS E LIVROS DE MÁRIO PEDROSA :}

PEDROSA, M. A crise mundial do imperialismo e Rosa Luxemburgo. Rio de Janeiro: Editora Civilização Brasileira, 1979.

\section{6.}

A opção imperialista. Rio de Janeiro: Editora Civilização Brasileira, $\overline{1966 .}$

A opção brasileira. Rio de Janeiro: Editora Civilização Brasileira, “A rebelião romântica e o espírito prussiano”, (?), c. 1928.

escolhidos).

- Acadêmicos e modernos. São Paulo: EDUSP, 1995. (Textos

. "Alguns aspectos do fascismo" In Sob Nova Bandeira, no 03, Rio de Janeiro, setembro de 1937. (pseudônimo Gonzaga).

1979.

Arte, forma e personalidade. São Paulo: Kairós Livraria e Editora, Janeiro, 06 de maio de 1956. Perspectiva, 1981.

Dos murais de Portinari aos espaços de Brasília. São Paulo: Editora escolhidos)

Forma e percepção estética. São Paulo: EDUSP, 1995. (Textos

"Ideologia e ciências sociais" In Jornal do Brasil, Rio de Janeiro, 12 05-1957.

. Mundo, homem, arte em crise. São Paulo: Perspectiva, 1975.

O poder nacional - as ideologias e sua significação para o poder nacional. Rio de Janeiro: EMFA, Escola Superior de Guerra, Curso Superior de Guerra, 1955.

. Obras completas: Política das artes. Otília B. F. Arantes (org.), revisão e normalização Iná Camargo Costa, Volume 01, S. L., S. N., 198-. (Cópia no Museu de Arte Contemporânea da USP).

. Obras completas: As bienais de São Paulo. Otília B. F. Arantes (org.), revisão e normalização Iná Camargo Costa, Volume 02, S. L., S. N., 198 -.

Obras completas: O Salão Nacional e outras mostras. Otília B. F. Arantes (org.), revisão e normalização Iná Ca margo Costa, Volume 03, S. L., S. N., 198-.

Obras completas: Arte-educação, escolas e museus. Otília B. F. Arantes (org.), revisão e normalização Iná Camargo Costa, Volume 04, S. L., S. N., 198-.

Obras completas: Arte, necessidade vital. Otília B. F. Arantes (org.), revisão e normalização Iná Camargo Costa, Volume 05, S. L., S. N., 198 -. 
PEDROSA, M. Obras completas: Forma e personalidade. Otília B. F. Arantes (org.), revisão e normalização Iná Camargo Costa, Volume 06, S. L., S. N., 198 -.

. Obras completas: Especulações estéticas. Otília B. F. Arantes (org.), revisão e normalização Iná Camargo Costa, Volume 07, S. L., S. N., 198 -.

Obras completas: Arte de ontem e de hoje. Otília B. F. Arantes (org.), revisão e normalização Iná Camargo Costa, Volume 08, S. L., S. N., 198 -.

- Obras completas: Panorama da pintura e crônicas do Oriente e do Ocidente. Otília B. F. Arantes (org.), revisão e normalização Iná Camargo Costa, Volume 09, S. L., S. N., 198-.

Obras completas: Da Missão Francesa aos mestres brasileiros. Otília B. F. Arantes (org.), revisão e normalização Iná Camargo Costa, Volume 10, S. L., S. N., 198-.

Obras completas: Ainda os artistas brasileiros. Otília B. F. Arantes (org.), revisão e normalização Iná Camargo Costa, Volume 11, S. L., S. N., 198-.

. Obras completas: arquitetura e cidades novas. Otília B. F. Arantes (org.), revisão e normalização Iná Camargo Costa, Volume 12, S. L., S. N., 198-.

Os socialistas e a III guerra mundial. Rio de Janeiro: Vanguarda Socialista, 13-11-1948.

. Política das artes. São Paulo: EDUSP, 1995. (Textos escolhidos).

"The defense of the U.S.S.R. in the present war", 09-11-1939.

"Villa-Lobos et son peuple" In La Revue Musicale, Paris, novembro de 1929. outubro de 1940 .

"What next in Latin America" In New International, New York,

PEDROSA, M. \& XAVIER, L. "Esboço de análise da situação brasileira" In A luta de classe, Rio de Janeiro, 03-02-1931.

Vanguarda Socialista, (Diretor e Editor Mário Pedrosa), Rio de Janeiro, S. N., 1945 1948.

\section{DEPOIMENTOS E ENTREVISTAS DE MÁRIO PEDROSA:}

"O mundo perdeu seus mitos". Depoimento de Mário Pedrosa a Paulo Mendes Campos para o jornal Diário Carioca, Rio de Janeiro, ano XX, $2^{\text {a }}$ seção, n5.943, novembro de 1947.

"Só duas vezes por ano o crítico vai à praia". Entrevista concedida ao jornal Tribuna da Imprensa, 09 de dezembro de 1955.

"Mário Pedrosa verifica em Bruxelas: falta horizonte para a pintura moderna", Suplemento Dominical do Jornal do Brasil, 25 de maio de 1958. Depoimento de Mário Pedrosa a Ferreira Gullar.

"Mário Pedrosa diz no Japão que as tradições morreram". Suplemento Dominical do Jornal do Brasil, (?) de abril de 1959. Depoimento de Mário Pedrosa a Ferreira Gullar. 
"O nacionalismo é uma ideologia alienante". Entrevista de Mário Pedrosa a Carlos Diegues e César Guimarães para o jornal O Metropolitano, Rio de Janeiro, 12 de julho de 1959.

"Mário Pedrosa e a VI Bienal de São Paulo". Entrevista de Mário Pedrosa ao jornal La Nación, (?) de setembro de 1961.

Depoimento de Mário Pedrosa a Vera Pedrosa para o jornal Correio da Manhã, 11 e 12 de setembro de 1968.

"Para Mário Pedrosa, a Bienal hoje é uma promoção superada". Depoimento a Sheila Leiner para o jornal O Estado de São Paulo, 31 de agosto de 1975.

"Mário Pedrosa, um coerente". Depoimento de Mário Pedrosa a Maria Lúcia Rangel para o Jornal do Brasil, 12 de outubro de 1977.

"Mário Pedrosa - Confis sões de um livre pensador". Entrevista a C. Kahns. Folha de São Paulo, 20 dezembro de 1977.

"A escolha do crítico que cansou da vanguarda: a arte indígena.”. Entrevista de Mário Pedrosa a Casimiro Xavier de Mendonça para o Jornal da Tarde, 31 de dezembro de 1977.

“Mário Pedrosa - A arte está em decadência mas os sindicatos estão vivos". Entrevista de Mário Pedrosa a Cícero Sandroni para o Jornal do Brasil, 02 de junho de 1978.

"Mário Pedrosa - repensando uma estética nacional a partir das cinzas do MAM". Entrevista de Mário Pedrosa a Maria Angélica Carvalho para o jornal O Globo, 14 de julho de 1978.

"Mário Pedrosa, profeta da arte". Depoimento de Pedrosa a Fábio Magalhães para o Diário de São Paulo, 08 de novembro de 1978.

“O Brasil não conhece o Brasil”. Depoimento de Mário Pedrosa para o jornal Tribuna da Imprensa, 30 e 31 de dezembro de 1978.

"Vanguardas brasileiras, uma questão aberta ao debate". Reportagem de Leonor Amarante para o jornal O Estado de São Paulo, 10 de junho de 1979.

"Eu sou um pensador, sou um pacifista". Depoimento de Mário Pedrosa a Jefferson del Rios para o jornal Folha de São Paulo, Ilustrada, São Paulo, 13 de abril de 1980.

"O mundo fantástico de Mário Pedrosa". Entrevista de Mário Pedrosa a Alberto Delerue para o jornal Tribuna da Imprensa, 29 de abril de 1980.

““Sou cético”. Diante da crítica, de arte, do mundo". Depoimento de Mário Pedrosa a Roberto Pontual para o Jornal do Brasil, (?) de abril de 1980.

“A arte não é fundamental. A profissão do intelectual é ser revolucionário...". Entrevista concedida ao Pasquim, 18 de novembro de 1981.

\section{ARTIGOS, CATÁLOGOS, ENSAIOS E TESES SOBRE MÁRIO PEDROSA:}

ABRAMO, F. \& KAREPOVS, D. (orgs.) Na contracorrente da história. Documentos da Liga comunista internacionalista, 1930-1933. São Paulo: Editora Brasiliense, 1987. 
ARANTES, Otília B. F. Mário Pedrosa: Itinerário crítico. São Paulo: Página Aberta, 1991.

FIGUEIREDO, C. E. de Sena. Mário Pedrosa: retratos do exílio. Rio de Janeiro: Edições Antares, 1982.

GUllaR, F. “A Mário Pedrosa com carinho". Caderno Mais, Folha de São Paulo, 16-04-2000.

Homem - homenagem a Mário Pedrosa. Rio de Janeiro: Galeria Boghici, Rio de Janeiro, abril/julho de 1980.

Homenagem a Mário Pedrosa. São Paulo: Fundação Bienal de São Paulo, 1980.

GERCHMANN, M. I. O abstracionismo geométrico na concepção de Mário Pedrosa: a relação com o desenvolvimento. Dissertação de mestrado apresentada ao Departamento de História da Pontifícia Universidade Católica do Rio Grande do Sul, Porto Alegre, 1992. Profa. Orientadora Maria Lúcia Bastos Kern.

JUSTINO, M. J. Mário Pedrosa e a morte da crítica de arte. Dissertação de mestrado apresentada ao Departamento de Educação da Pontifícia Universidade Católica de São Paulo, São Paulo, 1983. Prof. Orientador Bento Prado Júnior.

LOUREIRO, I. M. Vanguarda socialista (1945-1948): um episódio do ecletismo na história do marxismo brasileiro. Dissertação de mestrado apresentada ao Departamento de Filosofia da Faculdade de Filosofia, Letras e Ciências Humanas da USP, São Paulo, 1984. Profa. Orientadora Marilena Chauí.

MACHADO, G. Guelman G. Vanguarda socialista: a busca de um caminho independente. Dissertação de mestrado apresentada ao Departamento de Ciência Política da Faculdade de Filosofia, Letras e Ciências Humanas da USP, São Paulo, 1982. Prof. Orientador Oliveiros da Silva Ferreira.

MARI, M. Mário Pedrosa e Ferreira Gullar: sobre o ideário da crítica de arte nos anos 50 E 60. Dissertação de mestrado apresentada ao programa de pós-graduação da Escola de Comunicações e Artes da USP, São Paulo, 2001. Profa. Orientadora Silvia Miranda Meira.

Mário Pedrosa: arte, revolução, reflexão. Rio de Janeiro: Centro Cultural Banco do Brasil, 1992.

Mário Pedrosa: 100 anos. São Paulo: Fundação Memorial da América Latina, 2000.

MARQUES NETO, J. C. (org.) Mário Pedrosa e o Brasil. São Paulo: Editora Fundação Perseu Abramo, 2001.

Solidão revolucionária: Mário Pedrosa e as origens do trotskismo no Brasil. Rio de Janeiro: Paz e Terra, 1993.

MOLINA, C. "A coerência do pensamento crítico de Mário Pedrosa" In O Estado de São Paulo, Caderno 2, São Paulo, 10 de abril de 2005.

REBELDES BRASILEIROS - Homens e mulheres que desafiaram o poder: "Paulo Leminski - Mário Pedrosa"; coleções Caros Amigos, São Paulo, n 09, s. d.

RIBEIRO, F W. P. Botânica no asfalto. Dissertação de mestrado apresentada ao Departamento de História da pontifícia Universidade Católica do Rio de Janeiro, Rio de Janeiro, 2001. Prof. Orientador Marcelo Gantus Jasmin. 
BIBLIOGRAFIA GERAL:

ADAM, L. Arte primitiva. Lisboa: Edições Cosmos, 1943.

ADES, D. Art in Latin America: The Modern Era. London: South Bank Centre, 1989.

ADORNO, T. W. Notas de literatura I. São Paulo: Duas Cidades, Editora 34, 2003.

Notes sur la littérature. Paris : Flammarion, 1984.

ALMEIDA, P. M. de. De Anita ao Museu. São Paulo: Perspectiva, 1976.

ANDRADE, M. Aspectos das artes plásticas no Brasil. São Paulo: Livraria Martins, 1965.

$\overline{1942 .}$ Movimento modernista. Rio de Janeiro: Casa do Estudante do Brasil, O baile das quatro artes. São Paulo: Livraria Martins Editora, c. 1945.

AMARAL, A. Arte e meio artístico: entre a feijoada e o xburger (1961-1981). São Paulo: Nobel, 1983.

N., 1983. . Arte para quê? A preocupação social na arte brasileira. São Paulo: S. . Artes plásticas na Semana de 22. São Paulo: Editora 34, 1998. . Aspectos do não-objetualismo no Brasil. S. L., 1981.

Projeto construtivo brasileiro na arte (1950-1962). Rio de Janeiro (FUNARTE); São Paulo (Pinacoteca do Estado), 1977.

ANTIÁSOV, M. Panamericanismo: doctrina y hechos. Moscou: Editorial Progresso, 1986.

ARANTES, Otília B. F. O lugar da arquitetura depois dos modernos. São Paulo: EDUSP/ Studio Nobel, 1993.

. Urbanismo em fim de linha. São Paulo: EDUSP, 1988.

ARANTES, Otília B. F. et alii. A cidade de pensamento único: desmanchando consensos. Rio de Janeiro: Vozes, 2000.

ARANTES, O. B. F. \& ARANTES, P. Sentido da formação - três estudos sobre Antonio Candido, Gilda de Mello e Souza e Lúcio Costa. São Paulo: Página Aberta, 1991.

ARANTES, P. E. "Sofística da assimilação" In Praga, n 8, São Paulo: HUCITEC, 1999.

ARGAN, G. C. L'arte moderna. Florença: Sansone Editore, 1982.

ARNHEIM, R. Arte e percepção visual: uma psicologia da visão criadora. São Paulo: Pioneira - EDUSP, 1986.

ARTE EM REVISTA. (número 1, 2), ano 1, 1979. São Paulo: Kairós Livraria e Editora. 
BENEVIDES, M. V. de M. O governo de Kubitschek: desenvolvimento econômico e estabilidade política (1956-1961). Rio de Janeiro: Paz e Terra, 1979.

BENJAMIN, W. Charles Baudelaire: um lírico no auge do capitalismo. São Paulo: Brasiliense, 1995.

Magia e técnica, arte e política. São Paulo: Brasiliense, 1995.

BENSE, M. Pequena estética. São Paulo: Perspectiva, 1971.

BÉRTOLA, ELENA de. El arte cinético: el movimiento y la transformación; analisis perceptivo y funcional. Buenos Aires: Nueva Vision, 1973.

BRETON, A. Manifestos do surrealismo. Rio de Janeiro: NAU Editora, 2001. Oeuvres complètes. Paris: Gallimard, 1988. . Surrealisme et la peinture. New York: Brentano, 1945.

BRETON, A \& TROTSKY, L. Por uma arte revolucionária. São Paulo: Paz e Terra, 1985.

BRETT, G. Art Kinetic. London: Studio-Vista, 1968.

BRIONY, FER et alii. Realismo, racionalismo, surrealismo: a arte no entre-guerras. São Paulo: Cosac \& Naify Edições, 1998.

BRITO, R. "O moderno e o contemporâneo - o novo e o outro novo" In VVAA - Arte Brasileira Contemporânea. Caderno de Textos 1. Rio de Janeiro, FUNARTE, 1980.

O Neoconcretismo: vértice e ruptura do projeto construtivo brasileiro. Rio de Janeiro: FUNARTE, 1985.

BURNHAM, J. The managerial revolution: what is happening in the world? New York: Penguin Books, 1941.

CABANNE, P. Marcel Duchamp: engenheiro do tempo perdido. São Paulo: Ed. Perspectiva, 1987.

CANDIDO, A. Formação da literatura brasileira. (V.1-2). Rio de Janeiro: Editora Itatiaia, 1993.

CANDIDO, A. Literatura e sociedade. São Paulo: T. A. Queiroz, 2000.

Presença da literatura brasileira, história e crítica: modernismo. Rio de Janeiro: Bertrand Brasil, 1997.

CAMPOS, A., CAMPOS, H. \& PIGNATARI, D. Teoria da poesia concreta. São Paulo: Livraria Duas Cidades, 1975.

CAMPOS, H. A arte no horizonte do provável. São Paulo: Ed. Perspectiva, 1969.

CARDOSO, M. L. Ideologia do desenvolvimento - Brasil: JK-JQ. Rio de Janeiro: Pa e Terra, 1978.

CARONE, E. A república nova (1930-1937). São Paulo: Difel, 2a ed., 1976.

São Paulo: Difel, 1985.

A República liberal - instituições e classes sociais (1945-1964). V. I. 
Difel, 1985.

A República liberal - evolução política (1945-1964). V. II. São Paulo:

Livro, 1973.

A segunda república (1930-1937). São Paulo: Difusão Européia do . Da esquerda à direita. Belo Horizonte: Oficina de Livros, 1991.

. O Estado Novo. Rio de Janeiro, São Paulo: Difel, 1976.

. O P.C.B. (1943-1964). São Paulo: Difel, 1982.

CARPEAUX, O. M. As revoltas modernistas na literatura. São Paulo: Ediouro, s. d.

CHIPP, H. B. Theories of modern art. Berkeley: University of California Press, 1969.

COCCHIARELLI, F. \& GEIGER, A. B. Abstracionismo: geométrico e informal - a arte brasileira nos anos cinqüenta. Rio de Janeiro: FUNARTE, 1987.

COGGIOLA, O. et alli. Trotsky/hoje. São Paulo: Editora Ensaio, 1994.

COLBY, G. \& DENNETT, C. Seja feita a vossa vontade: a conquista da Amazônia: Nelson Rockefeller e o evangelismo na idade do petróleo. Rio de Janeiro: Record, 1998.

COMBALÍA, V. La poética de lo neutro y la crítica de la arte conceptual. Barcelona: Editorial Anagrama, 1975.

CORBISIER, R. Formação e problema da cultura brasileira. Rio de Janeiro: MEC/ISEB, 1960.

DASSIN, J. Política e poesia em Mário de Andrade. São Paulo: Livraria Duas Cidades, 1978.

DELACAMPAGNE, C. História da filosofia no século XX. Rio de Janeiro: Zahar Editores, 1997.

DEUTSCHER, I. Deutscher: política. (org. Juares Brandão Lopes). São Paulo: Ática, 1982.

DEUTSCHER, I. Ironias de la historia. Barcelona: Ediciones Península, 1975.

Civilização Brasileira, 1984.

Trotski: o profeta banido, 1929-1940. Rio de Janeiro: Ed.

DOESBURG, T. V. Principles of neo-plastic art. New York: Ny Graphic society, 1966.

FABBRINI, R. N. A arte depois das vanguardas. Tese de Doutorado apresentada ao Departamento de Filosofia da Faculdade de Filosofia, Letras e Ciências Humanas da USP, São Paulo, 1998. Prof. Orientador Leon Kossovitch.

O espaço de Lygia Clark. São Paulo: Atlas, 1994.

FABRIS, A. T. Portinari: Pintor social. São Paulo: EDUSP \& Perspectiva, 1990.

FAUSTO, B. História do Brasil. São Paulo: EDUSP, 1995.

História geral da civilização brasileira. V.III, São Paulo: Bertrand Brasil,

1995. 
FAVARETTO, C. F. A invenção de Hélio Oiticica. São Paulo: EDUSP, 1992.

"Restauração e resgate na arte contemporânea" In BARBOSA, AMT.

Ensino das artes nas universidades de São Paulo: USP, 1993.

. Tropicália - alegoria, alegria. São Paulo: Ateliê Editorial, 1996.

FERNANDES, F. Capitalismo dependente e classes sociais na América Latina. Rio de Janeiro: Zahar Editores, 1975.

FERRAZ, G. Retrospectiva: figuras, raízes e problemas da arte contemporânea. São Paulo: Cultrix, EDUSP, 1975.

FIZ, Simón M. Del arte objectual al arte del concepto: las artes plásticas desde 1960. Madrid: A. Corazón, 1972.

GOODING, M. Arte abstrata. São Paulo: Cosac \& Naify, 2002.

GREENBERG, C. "Depois do expressionismo abstrato". Gávea, n 3, Rio de Janeiro, 1986.

GULlAR, F. "Cubismo" In Arte \& informação. São Paulo: Editora Ar de Paris, número 1, maio de 2000.

Cultura posta em questão. Rio de Janeiro: Editora Civ. Brasileira, 1965.

Brasileira, 1969.

Vanguarda e subdesenvolvimento. Rio de Janeiro: Editora Civ.

GUILBAUT, S. How New York stole the idea of the modern art - abstract expressionism, freedom, and the cold war. Chicago: The University of Chicago Press, 1985.

GUILBAUT, S. "Postwar painting games" In Reconstructing modernism: art in New York, Paris and Montreal, 1954-1964. Massachusetts: MIT, 1990.

GUILLAUME, P. La psychologie de la forme. Paris: Flammarion, 1975.

HABERMAS, J. "Modernidade versus pós-modernidade" In Arte em revista, n 7, São Paulo: CEAC, 1981.

HADDAD, F. O sistema soviético: relato de uma polêmica. São Paulo: Editora Página Aberta, 1992.

HARRISON, C. \& WOOD, P. Art in theory: 1900-1990. UK: Blackwell Publishers Ltd., 1999.

HARRISON, C. et alii. Primitivismo, cubismo, abstração - Começo do século XX. São Paulo: Cosac \& Naify Edições, 1998.

HOBSBAWM, E. Era dos extremos: o breve século XX (1914-1991). São Paulo: Companhia das Letras, 1995.

Paz e Terra, 1986.

(org.) História do marxismo. (Volume: IX, X, XI e XII). São Paulo:

HOLANDA, H. B. de, Impressões de viagem - CPC, vanguarda e desbunde: 1960/1970. São Paulo: Ed. Brasiliense, 1981.

HUTTINGER, E. Max Bill. Zürich: Abc-Verlag, 1978.

HUYSSEN, A. Memórias do modernismo. São Paulo: Martins Fontes, 1991. 
INSTITUTO CULTURAL ITAÚ. “Arte e sociedade”, São Paulo, 2003.

JAMESON, F. Pós-modernis mo: a lógica cultural do capitalismo tardio. São Paulo: Ática, 1997.

KANDINSKY, W. La gramática de la creacion - el futuro de la pintura. Barcelona: Paidos, 1987.

KOFFKA, K. Princípios de psicologia da Gestalt. São Paulo: Editora Cultrix \& EDUSP, 1975.

Lectura, s. d.

Teoria de la estructura: la psicologia nivisima. Madrid: Ediciones de la

KÖHLER, W. Psicologia da Gestalt. Belo Horizonte: Editora Itatiaia, 1968.

LAFETÁ, J. L. Os pobres na literatura brasileira. (org. Roberto Schwarz). São Paulo: Brasiliense, 1983.

LAFETÁ et alii. Artes plásticas: o nacional e o popular na cultura brasileira. São Paulo: Editora Brasiliense, 1982.

LEFEBVRE, H. Le matérialisme dialectique. Paris, Presses Universitaires de France, 1949.

LENIN, V. I. La Literatura y el Arte. Moscou: Editorial Progresso, 1979.

Obras escolhidas. (V. 1). São Paulo: Editora Alfa-Ômega, 1986.

LEWIN, K. Princípios de psicologia topológica. São Paulo: Cultrix, 1973.

LOUREIRO, I. M. Rosa Luxemburgo - os dilemas da ação revolucionária. São Paulo: Editora da UNESP, 1995.

2000. Rosa Luxemburgo: vida e obra. São Paulo: Editora Expressão Popular,

LÖWY, M. Ideologias e ciência social: elementos para uma análise marxista. São Paulo: Cortez, 1999.

. (org.) O marxismo na América Latina - uma antologia de 1909 aos dias atuais. São Paulo: Fundação Perseu Abramo, 1999

LUXEMBURGO, R. A questão nacional e a autonomia. (Coleção Fundamentos). Belo Horizonte: Oficina de Livros, 1988.

Escritos sobre arte y literatura. Havana: Editorial Estampa, 1985.

LYOTARD, J. F. Fenomenologia. São Paulo: Martins Fontes, 1954.

MACHADO, C. E. J. Um capítulo da história da modernidade estética: Debate sobre o expressionismo - Ernest Bloch, Hanns Eisler, Georg Lukacs e Bertold Brecht. São Paulo: UNESP, 1998.

MACIEL, L. C. Anos 60. RS: L\& PM Editores, 1987.

MALEVITCH, K. Écrits. Lausanne: L'age d'homme, 1974.

MANNHEIM, K. Ideologia e utopia. Rio de Janeiro: Zahar Editores, 1976. 
Sociologia sistemática. São Paulo: Livraria Pioneira Editora, 1962.

MARCUSE, H. Eros e civilização: uma interpretação filosófica do pensamento de Freud. Rio de Janeiro: Zahar, 1975. Le marxisme soviétique. Paris: Éditions Gallimard, 1963.

MARX, K. Crítica ao programa de Gotha. Porto: Portucalense, 1971. O 18 brumário e cartas a Kugelmann. São Paulo: Paz e Terra, 1997. Manifesto do partido comunista. Petrópolis: Editora Vozes, 2000.

MARX, K. \& ENGELS, F. A ideologia alemã. São Paulo: Martins Fontes, 1998.

MERLEAU-PONTY, M. “A dúvida de Cézanne” In Coleção “Os Pensadores”, São Paulo: Editora Abril, 1975.

France, 1953. La Structure du Comportement. Paris: Presses Universitaires de Fenomenologia da percepção. São Paulo: Martins Fontes, 1996.

MILLIET, S. Pintores e pinturas. São Paulo: Martins, 1940.

MOLES, A. Teoria da informação e perepção estética. Rio de Janeiro: Edições Tempo Brasileiro, 1969.

MONDRIAN, P. Nueva imagen en la pintura. Murcia: Col. del aparejadores e arquitectos tecn., 1983.

1952. Plastic art and pure plastic art. New York: Wittenborn, Schultz,

MORAES, J. Q. de. (org.). História do marxismo no Brasil - os influxos teóricos. Volume II. Campinas, SP: Editora da Unicamp, 1995.

MORAIS, F. Artes plásticas: a crise da hora atual. Rio de Janeiro: Paz e Terra, 1975. Editora, 1983. Chorei em Bruges - crônicas de amor à arte. Rio de Janeiro: Avenir

MOREIRA, M. Cândido Portinari. Coleção “A vida dos grandes brasileiros”. São Paulo: Editora Três Ltda., 2003.

MOTA, C. G. Ideologia da cultura brasileira. São Paulo: Ed. Ática, 1975.

MUSEU DE ARTE MODERNA DO RIO DE JANEIRO. “Nova Objetividade”, 1997.

NADEAU, M. História do surrealismo. São Paulo: Editora Perspectiva, 1985. Le roman français depuis la guerre. Paris: Gallimard, 1963.

NAVILLE, P. La révolution et les intellectuels. Paris: Librarie Gallimard, 1927. 1946. Psychologie, marxisme, materialisme: Essai critique. Paris: Riviere,

OITICICA, H. "Objeto - instâncias do problema do objeto" In GAM: Galeria de arte moderna, número: 15, Rio de Janeiro, 1968. 
Aspiro ao Grande Labirinto. Rio de Janeiro: Rocco, 1986.

PARIS-MOSCOU/ 1900-1930. Paris, Centre Georges Pompidou, 1979.

PONTUAL, R. Dicionário das artes plásticas no Brasil. Rio de Janeiro: Civ. Brasileira, 1969.

PEVSNER, N. Origens da arquitetura moderna e do design. São Paulo: Martins Fontes, 1981.

PRADO JUNIOR, C. A revolução brasileira. São Paulo: Editora Brasiliense, 1978.

PRADO JUNIOR, C. História e desenvolvimento: a contribuição da historiografia para a teoria e prática do desenvolvimento brasileiro. São Paulo: Editora Brasiliense, 1999.

READ, H. A arte de agora agora. São Paulo: Editora Perspetiva, 1991. A arte e a sociedade. Lisboa: Edições Cosmos, 1946.

RESTANY, P. Os novos realistas. São Paulo: Editora Perspectiva, 1979.

RIGNANO, E. "La Théorie de la Forme” In Problèmes de psychologie et de morale. Paris: Librairie Félix Alcan, 1928.

RIZZI, B. The bureaucratization of the world: The USSR: Bureaucratic collectivism. London: Tavistock, 1985.

RÖHL, R. O teatro de Heiner Müller: Modernidade e pós-modernidade. São Paulo: Perspectiva, 1997.

SCHWARTZMAN, S. Tempos de Capanema. Rio de Janeiro: Paz \& Terra; São Paulo: EDUSP, 1984

SCHWARZ, R. Ao vencedor as batatas. São Paulo: Duas Cidades, 1977. O pai de família e outros escritos. Rio de Janeiro: Paz e Terra, 1986. Que horas são? São Paulo: Cia. das Letras, 1987.

SEATON, E. G. Federal prints and democratic culture: the graphic arts division of the Works Progress Administration Federal Art Project, 1935-1943. Tese de Doutorado. Northwestern University, Illinois, 2000.

SHERWOOD, R. E. Roosevelt e Hopkins: uma his tória da Segunda Guerra Mundial. Rio de Janeiro: Nova Fronteira, 1998.

SKIDMORE, T. E. Brasil: de Getúlio Vargas a Castelo Branco, 1930-1964. Rio de Janeiro: Paz e Terra, 1982.

Uma história do Brasil. Rio de Janeiro: Editora Paz e Terra, 2000.

SMITH, R. C. Murals by Cândido Portinari. Washington: The Hispanic Foundation of the Library of Congress, 1943.

TACUCHIAN, M. de F. G. Panamericanismo, propaganda e música erudita: Estados Unidos e o Brasil (1939-1948). Tese de doutorado apresentada ao Departamento de História da Faculdade de Filosofia, Letras e Ciências Humanas da Universidade de São Paulo. Orientador: Prof. Dr. Arnaldo Daraya Contier. 1998. 
TOBIAS, J. A. História da idéias estéticas no Brasil. São Paulo: Editorial Grijalbo, 1967.

TOLEDO, J. Flávio de Carvalho - O comedor de emoções. São Paulo: Brasiliense \& Editora da Universidade Estadual de Campinas, 1994.

TOTA, A. P. O imperialismo sedutor: a americanização do Brasil na época da Segunda Guerra. São Paulo: Companhia das Letras, 2000.

TROTSKI, L. 1905: resultados y perspectivas. Paris: Ruedo Iberico Éditions, 1971.

“A recent lesson” In New International, New York, dezembro de 1938. Disponível em: <http://www.ceip.org.ar/escritos/Libro6/html/T10V111.htm\#_ftn1>.

. A revolução permanente. Lisboa: Edições Antídoto, 1977.

A revolução traída. São Paulo: Editora Global, 1980.

"El arte revolucionario y la Cuarta Internacional" In Litterature et

Revolution, editado por Maurice Nadeau (1964). Disponível em: <http://www.ceip.org.ar/escritos/libro5/html/T09V238.htm>.

TROTSKI, L. En Defensa del marxismo. Buenos Aires: El Yunque Editora, 1975.

1977.

História da revolução russa. Rio de Janeiro: Paz e Terra, V. (I, II e III),

. La revolucion traicionada. Buenos Aires: El Yunque Editora, 1973.

Literatura e revolução. Rio de Janeiro: Zahar Editores, 1980.

- "Neither a labor state neither a bourgeois state?" Internal Bulletin

(OCSPC), $\mathrm{N}^{\circ}$. 3, dezembro de 1937. Disponível em: <http://www.marxists.org/archive/trotsky/works/1937/1937-ws.htm\#a1>.

.““Pro Cuarta Internacional? ¡No! ¡La Cuarta lnternacional!, Internal Bulletin, SWP, $\quad \mathrm{N}^{\mathrm{o}} 3, \quad \mathrm{de} 1938 . \quad$ Disponível em: <http://www.ceip.org.ar/escritos/Libro/html/T09V237.htm>.

1968. Revolução e contra-revolução. Rio de Janeiro: Editora Laemmert S. A.,

. "The USSR in war", 25-09-1939, In Defense of marxism. Disponível em: <http//www.marxists.org/archive/trotsky/works/1942-dm/ch01.htm>.

Trotski a Farrell Dobbs (Carta). Coyoacan, 04-03-1940. Disponível em: <http//www.marxists.org/archive/trotsky/works/1942-dm/ch06.htm>.

Trotski a Farrell Dobbs (Carta). Coyoacan, 04-04-1940. Disponível em: <http://www.marxists.org/archive/trotsky/works/1942-dm/ch06.htm>.

VITA, L. W. Tendências do pensamento estético contemporâneo no Brasil. Rio de Janeiro: Civilização Brasileira, 1967.

WALD, A. M. The New York intellectuals: the rise and decline of the anti-stalinist left from the 1930s to the 1980s. North Carolina: The University of North Carolina Press, 1987.

WOOD, P. et alii. Modernismo em disputa: a arte desde os anos quarenta. São Paulo: Cosac \& Naify Edições, 1998. 
ZANINI, W. A arte no Brasil nas décadas de 1930-40 - o grupo Santa Helena. São Paulo: Nobel \& Editora da Universidade de São Paulo, 1991.

Salles, 1983.

. História geral das artes no Brasil. São Paulo: Instituto Walther Moreitra

Tendências da escultura moderna. São Paulo: Ed. Cultrix, 1971. 